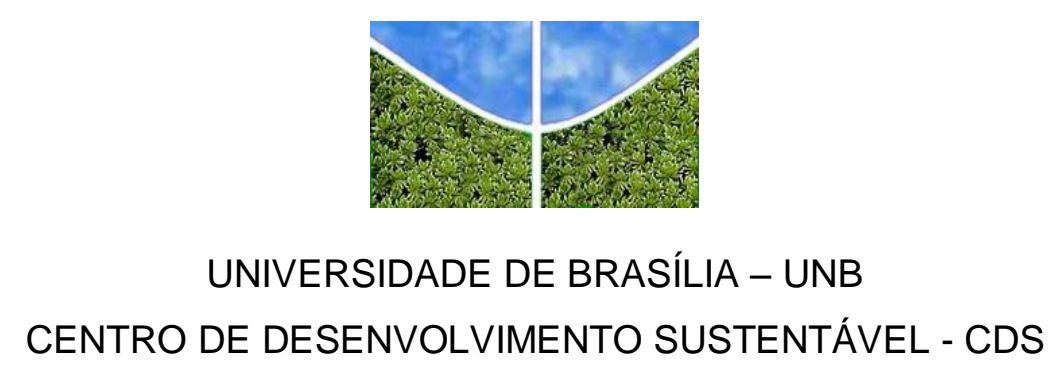

Conexão (in)visível:

Degradação ambiental e saúde na fronteira agrícola amazônica

Marla Leci Weihs

Orientadora: Doris Aleida Villamizar Sayago

Tese de Doutorado

Brasília-DF, março de 2015 


\title{
Conexão (in)visível: Degradação ambiental e saúde na fronteira agrícola amazônica
}

\author{
Marla Leci Weihs
}

Tese de Doutorado submetida ao Centro de Desenvolvimento Sustentável da Universidade de Brasília, como parte dos requisitos necessários para a obtenção do Grau de Doutora em Desenvolvimento Sustentável, área de concentração em Política e Gestão Ambiental.

Aprovado por:

Doris Aleida Villamizar Sayago (Doutora)

Membro Interno vinculado ao programa (Presidente)

Centro de Desenvolvimento Sustentável

Carlos José Sousa Passos (Doutor)

Membro Interno vinculado ao programa

UnB - Faculdade de Planaltina

Maria da Graça Luderitz Hoefel (Doutora)

Membro Interno não vinculado ao programa

Departamento de Saúde Coletiva

Ximena Pamela Claudia Diaz Bermudez (Doutora)

Membro Interno não vinculado ao programa

Departamento de Saúde Coletiva

Jean-François Tourrand (Doutor)

Membro Externo não vinculado ao programa

CIRAD - Centre de Cooperation Internacionale en Recherche

Walter Massa Ramalho (Doutor)

Membro Interno não vinculado ao programa (Suplente)

UnB - Faculdade da Ceilândia

Brasília-DF, março de 2015 
A ciência pode classificar e nomear todos os órgãos de um sabiá mas não pode medir seus encantos. A ciência não pode calcular quantos cavalos de força existem nos encantos de um sabiá. Quem acumula muita informação perde o condão de adivinhar: divinare.

Os sabiás divinam.

- Manoel de Barros "Sobre o nada" (1996, p. 53). 
Para os meus pais, Dirson e Vidamira, síntese de minhas aspirações para a vida.

Para Bianca e Felipe, pela cumplicidade e o amor. 


\section{AGRADECIMENTOS}

Àqueles com que pude compartilhar esta etapa importante da minha vida, agradeço com carinho:

Meus filhos Bianca e Felipe, por juntos caminharmos.

Meu companheiro Ivaldo, pela amorosidade, o diálogo e a valiosa correção do texto.

Meus pais Dirson e Vidamira, pelo irrestrito incentivo.

Meus irmãos Alison e Mey e sobrinhos Guilherme, Marina, Davi e Luca, pela amizade.

Meus amigos e amigas: Silvia Borges, Patricia Mesquita, Marcos Lima, Danielle Calandino, Carolina Araújo, João Paulo Tasso, Lourdes larema, Osmar Coelho, Pablo Pessoa, Michelle Morimura, Márcia Camargo, Bárbara Babi, Celma Prado e Mário Berto, pelo encontro.

Meus queridos amigos Jeane Maria e Vander Rocha, pela grandeza da alma.

Ma chère amie, Annick van Ginneken, merci pour l'enseignement et le soutien en France.

Meus mestres Doris Sayago e Jean-François Tourrand, pelos ensinamentos.

Aos que me oportunizaram esta conquista:

Universidade do Estado de Mato Grosso (UNEMAT).

Fundação de Amparo à Pesquisa do Estado de Mato Grosso (FAPEMAT).

Coordenação de Aperfeiçoamento de Pessoal de Nível Superior (CAPES).

E em especial:

Centro de Desenvolvimento Sustentável (CDS), Universidade de Brasília (UnB).

Centre de Coopération Internationale en Recherche Agronomique pour le Développement (CIRAD).

Escritório Regional de Saúde da Microrregião do Alto Tapajós, Secretaria de Estado de Saúde de Mato Grosso.

Secretaria Municipal de Saúde de Alta Floresta - MT.

Secretaria Municipal de Saúde de Paranaíta - MT. 


\section{RESUMO}

No horizonte em que se projetam os problemas ambientais da Amazônia brasileira, as fronteiras agrícolas ocupam a primeira posição. A conversão das áreas de florestas em áreas de cultivo produziu desmatamento, incêndios florestais, erosão de solos e uma importante perda de espécies e diversidade genética. Ademais, os garimpos de ouro e as lavouras de soja contaminaram os ecossistemas, sobretudo com mercúrio e agrotóxicos. Como esses fenômenos afetaram a saúde da população? Esta foi a questão que orientou este estudo. Trata-se de uma pesquisa interdisciplinar e participativa, ancorada na área da saúde ambiental. $\mathrm{O}$ objetivo foi compreender a relação entre a degradação ambiental e a saúde coletiva. A pesquisa foi desenvolvida na fronteira agrícola de Alta Floresta, situada no Norte do Estado de Mato Grosso. No curso do avanço da ocupação agrícola desta fronteira houve uma notável transição de doenças infectoparasitárias para doenças crônicas. Neste contexto, a emergência das doenças foi condicionada, entre outros fatores, pela degradação do meio ambiente. Ao longo da ocupação da região, o desmatamento potencializou a exposição dos trabalhadores aos insetos transmissores da malária. As queimadas florestais produziram partículas atmosféricas tóxicas que aumentaram a prevalência das doenças respiratórias. O acúmulo de mercúrio e agrotóxicos nos ecossistemas, por sua vez, condicionou o perfil recente da saúde pública. No quadro atual, sob o ponto de vista da saúde, a fronteira de Alta Floresta está integrada ao território nacional. Entretanto, a contaminação agrícola continua sendo o principal determinante da emergência das doenças. No cenário futuro, a saúde pública dependerá, entre outros fatores, de uma reconfiguração do sistema de produção agrícola, com foco na regulação do consumo de pesticidas. Adicionalmente, verificou-se a necessidade de uma reorientação do sistema de saúde em que concerne à gestão dos riscos de origem agrícola.

PALAVRAS-CHAVE: saúde ambiental, fronteira agrícola, Amazônia, agrotóxicos, risco. 


\begin{abstract}
Agricultural frontiers occupy the first position among the set of environmental problems that impact the Brazilian Amazon. The conversion of forest areas in cultivated ones produced deforestation, forest fires, soil erosion and an important loss of biodiversity, including genetic diversity. Additionally, gold mining and soy fields have contaminated the ecosystem, especially with mercury and pesticides. How these phenomena have affected public health? This was the guiding question for the research, an interdisciplinary and participatory exploration supported by the environmental health area, with the objective of understanding the relationship between environmental degradation and public health. The research was conducted in the Alta Floresta agricultural frontiers, in the north of the Mato Grosso state, Brazil. A remarkable transition from infectious and parasitic diseases to chronic diseases has been observed during the advance of agricultural frontiers. In this context, the emergence of diseases was conditioned, among other factors, by the environmental degradation. Throughout the occupation of this region, deforestation increased the exposure of workers to insect vectors of malaria. Forest fires produced toxic atmospheric particles that increased prevalence of respiratory diseases. Meanwhile, mercury and pesticide accumulation on the ecosystem conditioned the recent profile of public health. In the present scenario, from the point of view of health, the frontier of Alta Floresta is integrated to the national territory. However, agricultural contamination remains the primary determinant of emerging diseases. We highlight that public health in the future will depend, among other factors, on the reconfiguration of agricultural systems, with emphasis on pesticide use regulation. Additionally, reorientation of the health care system is deemed necessary concerning the management of risks related to agricultural activities.
\end{abstract}

KEYWORDS: environmental health, agricultural frontier, Amazon, pesticides, risk. 


\section{RÉSUMÉ}

Les fronts pionniers sont l'un des phénomènes les plus importants pour la dévastation de l'Amazonie. Le processus d'occupation de l'espace, notamment agricole, a entraîné le défrichement de la forêt, des feux de forêt, l'érosion des sols et une importante perte de biodiversité. Par ailleurs, l'orpaillage clandestin et les cultures de soja contaminent l'environnement, principalement par l'action du mercure et des pesticides. Dans ce contexte, cette recherche a été guidée par la question suivante : quels impacts ces phénomènes ontils sur la santé publique ? II s'agit d'une recherche interdisciplinaire et participative, qui s'inscrit dans le registre de la santé environnementale. L'objectif était de comprendre les relations existantes entre dégradation de l'environnement et santé publique. La recherche a été conduite sur le front pionnier d'Alta Floresta, situé au nord de l'État brésilien du Mato Grosso. En parallèle de l'avancée de la frontière agricole, une transition notable s'est opérée en termes de santé, passant d'une situation dominée par les maladies infectieuses et parasitaires à une situation où les maladies chroniques prédominent. Dans ce contexte, la dégradation de l'environnement naturel a constitué un des facteurs responsables de l'émergence de maladies : au cours de l'occupation de la région, le déboisement a facilité l'exposition des travailleurs aux insectes transmetteurs du paludisme; les feux de forêt produisent des particules atmosphériques toxiques qui augmentent la fréquence des maladies respiratoires ; l'accumulation de mercure et de pesticides dans les écosystèmes ont conditionné, entre autres facteurs, le profil actuel des maladies chroniques. À l'heure actuelle, du point de vue de la santé, le front pionnier d'Alta Floresta est intégré au reste du pays. Cependant, la contamination agricole reste le principal facteur déterminant l'émergence de maladies. À l'avenir, la bonne conduite de la santé publique devra prendre en compte, entre autres, la reconfiguration du système de production agricole, particulièrement en ce qui concerne la réglementation liée à l'utilisation de pesticides. En outre, l'étude a montré que le système de santé, en ce qui concerne la gestion des risques d'origine agricole, méritait d'être réorienté.

MOTS-CLÉS : santé environnementale, front pionnier, Amazonie, pesticides, risque. 


\section{RESUMEN}

En la Amazonía brasileña, las fronteras agrícolas están entre los fenómenos más importantes en términos de devastación de los ecosistemas. La formación de las zonas de cultivo han producido la deforestación, los incendios forestales, la erosión del suelo y una importante pérdida de especies y de diversidad genética. Por otra parte, las minas de oro y cultivos de soya contaminan los ecosistemas, especialmente de mercurio y pesticidas. ¿Cómo estos fenómenos han afectado la salud de la población? Esta fue la pregunta que orientó el desarrollo de este estudio. Se trata de una investigación interdisciplinaria y participativa, basada en el área de la salud ambiental. El objetivo era comprender la relación entre la degradación del medio ambiente y la salud pública. La investigación fue realizada en la frontera agrícola de Alta Floresta, situada al norte del estado de Mato Grosso, Brasil. Se observó una importante transición de enfermedades, en el transcurso de la ocupación agrícola. Enfermedades infectoparasitarias fueron reemplazadas progresivamente, para enfermedades crónicas. En este contexto, la degradación del medio ambiente, entre otros factores, ha determinado la aparición de enfermedades. En el transcurso de la ocupación de la región, la deforestación aumentó la exposición de los trabajadores a los insectos vectores de la malaria. Incendios forestales han producido partículas atmosféricas tóxicas que han aumentado la prevalencia de las enfermedades respiratorias. La acumulación de mercurio y pesticidas en los ecosistemas, a su vez, condicionó el perfil reciente de la salud pública. En el marco actual, desde el punto de vista de la salud, la frontera de Alta Floresta está integrada al territorio nacional. Sin embargo, la contaminación agrícola sigue siendo el principal factor determinante de la aparición de enfermedades crónicas. En el futuro, la salud pública dependerá, entre otros factores, de la reconfiguración del sistema de producción agrícola, en particular en lo relativo a la regulación del consumo de plaguicidas. Además, el estudio demostró la necesidad de una reorientación del sistema de salud en relación con la gestión del riesgo de origen agrícola.

PALABRAS CLAVE: salud ambiental, frontera agrícola, Amazonía, pesticidas, riesgo. 


\section{LISTA DE SIGLAS}

ADI - Alzheimer's Disease International

AIDS - Síndrome da Imunodeficiência Adquirida

AMESH - Metodologia Adaptativa para a Sustentabilidade do Ecossistema e da Saúde ANVISA - Agência Nacional de Vigilância Sanitária

APP - Áreas de Proteção Ambiental

AVC - Acidente Vascular Cerebral

BASA - Banco da Amazônia

BHC - Hexaclorobenzeno

BNDES - Banco Nacional de Desenvolvimento Econômico e Social

CAR - Cadastro Ambiental Rural

CARUSO - Contaminação e exposição ao mercúrio na Amazônia

CIRAD - Centre de Coopération Internationale en Recherche Agronomique pour le

Développement

COLNIZA - Colonização Comércio e Indústria

CONAMA - Conselho Nacional do Meio Ambiente

COPEL - Companhia Paranaense de Energia

CPT - Comissão Pastoral da Terra

DDT - Diclorodifeniltricloroetano

DSS - Determinação Social da Saúde

DST - Doença sexualmente transmissível

ERS - Escritório Regional de Saúde da microrregião do Alto Tapajós

FIOCRUZ - Fundação Oswaldo Cruz

FUNAI - Fundação Nacional do Indígena

FUNASA - Fundação Nacional de Saúde

IBAMA - Instituto Brasileiro do Meio Ambiente e dos Recursos Naturais Renováveis

IBGE - Instituto Brasileiro de Geografia e Estatística

ICV - Instituto Centro de Vida

INAMPS - Instituto Nacional de Assistência Médica da Previdência Social

INCRA - Instituto Nacional de Colonização e Reforma Agrária

INDECO - Integração, Desenvolvimento e Colonização

INPE - Instituto Nacional de Pesquisas Espaciais

INTERMAT - Instituto de Terras do Estado de Mato Grosso

IOV - Instituto Ouro Verde

MDA - Ministério do Desenvolvimento Agrário 
MDIC - Ministério do Desenvolvimento, Indústria e Comércio Exterior

MMA - Ministério do Meio Ambiente

OGM - Organismo Geneticamente Modificado

OMS - Organização Mundial da Saúde

ONG - Organização Não Governamental

PAC - Programa de Aceleração do Crescimento

PCMAM - Projeto de Controle da Malária na Bacia Amazônica

PIB - Produto Interno Bruto

PIN - Programa de Integração Nacional

$\mathrm{PM}_{2.5}$ - Particulate Matter

PMFS - Plano de Manejo Florestal Sustentável

PNUD - Programa das Nações Unidas para o Desenvolvimento

POLAMAZÔNIA - Programa de Polos Agropecuários e Agrominerais da Amazônia

PRODES - Programa de Cálculo do Desflorestamento da Amazônia

PRORURAL - Programa de Assistência Rural

PROTERRA - Programa de Redistribuição de Terras e de Estímulos à Agroindústria do

Norte e do Nordeste

PSF - Programa Saúde da Família

REDD - Redução das Emissões por Desmatamento e Degradação florestal

RENDANYL - Indústria de Rendas

SAF - Sistema Agroflorestal

SAMU - Serviço de Atendimento Móvel de Urgência

SEMA - Secretaria de Estado do Meio Ambiente

SES/MT - Secretaria de Estado de Saúde de Mato Grosso

SIAT - Sistema Integrado de Atendimento ao Trauma

SMS/AF - Secretaria Municipal de Saúde de Alta Floresta

SMS/PT - Secretaria Municipal de Saúde de Paranaíta

SUCAM - Superintendência de Campanhas de Saúde Pública

SUDAM - Superintendência do Desenvolvimento da Amazônia

SUS - Sistema Único de Saúde

UFRJ - Universidade Federal do Rio de Janeiro

UHE - Usina Hidrelétrica

UNEMAT - Universidade do Estado de Mato Grosso

USP - Universidade de São Paulo 


\section{LISTA DE FIGURAS}

Figura 1 - Representação esquemática das fases da evolução da fronteira agrícola.

Figura 2 - Ciclo de vida da fronteira.

Figura 3 - Ciclo biológico da malária, com destaque para o agente da doença (protozoário de gênero Plasmodium) e o mosquito transmissor (Anopheles).

Figura 4 - Modelagem das taxas de mortalidade padronizadas por doenças do aparelho circulatório por 100.000 habitantes, 2007.

Figura 5 - Formas de contaminação do ambiente com mercúrio, a partir da mineração artesanal de ouro.

Figura 6 - Localização geográfica de Alta Floresta, MT: Bioma, bacias hidrográficas e rodovias.

Figura 7 - As características das primeiras casas da zona rural de Alta Floresta.

Figura 8 - A cidade de Alta Floresta em 1976 e em 1978.

Figura 9 - A pesquisa foca a relação entre o meio ambiente e a saúde.

Figura 10 - Analisam-se as fases do ciclo de vida da fronteira, conectadas às transformações do meio ambiente e aos efeitos sobre a saúde da população.

Figura 11 - Etapas do trabalho de campo.

Figura 12 - Alguns dos participantes de entrevistas abertas.

Figura 13 - Primeira "linha do tempo", subsídio para a discussão dos grupos focais formados por profissionais da saúde.

Figura 14 - Grupos focais e conversas informais (1 ${ }^{\text {a }}$ fase).

Figura 15 - Segunda "linha do tempo", subsídio para a discussão dos grupos focais formados por agricultores, trabalhadores rurais e ex-garimpeiros.

Figura 16 - Exemplo de uma linha do tempo construída pelos participantes da segunda etapa de grupos focais.

Figura 17 - Moradores do bairro Vila Nova (agricultores e trabalhadores rurais), participantes do último grupo focal.

Figura 18 - Fase de restituição dos resultados preliminares.

Figura 19 - Complexo hidrelétrico do rio Teles Pires.

Figura 20 - Síntese do avanço da fronteira agrícola de Alta Floresta em etapas. 
Figura 21 - Linha histórica das doenças na fronteira agrícola de Alta Floresta.

100

Figura 22 - Fatores que contribuíram para a emergência da malária e para o controle da epidemia na fronteira agrícola de Alta Floresta.

Figura 23 - Fatores que contribuíram para a emergência das doenças respiratórias agudas e crônicas e para o seu controle na fronteira agrícola de Alta Floresta

Figura 24 - Linha histórica do comportamento das doenças crônicas (respiratórias, cardiovasculares, neurodegenerativas e cânceres) na fronteira de Alta Floresta.

Figura 25 - Exemplo de uma antiga cava de garimpo que serve atualmente como tanque de criação de peixes.

\section{LISTA DE QUADROS}

Quadro 1 - Informações gerais dos participantes da primeira etapa dos grupos focais.

Quadro 2 - Síntese da relação entre degradação/contaminação ambiental, risco e doenças, observada na fronteira de Alta Floresta

\section{LISTA DE GRÁFICOS}

Gráfico 1 - Taxa de Desmatamento na Amazônia Brasileira no período de 1988 a 2010 (km2/ano).

Gráfico 2 - Variação da população de Alta Floresta (1990 a 2010).

Gráfico 3 - a) Índice de Gini - comparação entre Alta Floresta, Mato Grosso e Brasil. b) Índice de pobreza em Alta Floresta. c) Renda per capita comparação entre Alta Floresta, Mato Grosso e Brasil. d) Pirâmide etária.

Gráfico 4 - Evolução do rebanho bovino em Alta Floresta, de 1981 a 2011.

Gráfico 5 - Registro de madeira exportada, extraída em Alta Floresta, em dólares.

Gráfico 6 - Acumulado do desmatamento até 2010, elaborado a partir de dados da SEMA e do PRODES/INPE.

Gráfico 7 - Concentração de partículas tóxicas de fumaça em Alta Floresta, de agosto de 1992 a setembro de 2002.

Gráfico 8 - Número de focos de incêndio - Alta Floresta, 2004 a 2013. 


\section{LISTA DE ANEXOS}

ANEXO I - Roteiro para as entrevistas

ANEXO II - Termo de Consentimento Livre e Esclarecido 171

ANEXO III - Síntese dos resultados 


\section{SUMÁRIO}

\section{INTRODUÇÃO GERAL}

\section{Capítulo 1. MEIO AMBIENTE E SAÚDE: PERSPECTIVAS DE UMA ÁREA}

EMERGENTE.

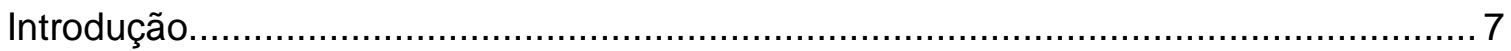

1.1. Breve introdução ao estudo da saúde humana ............................................. 7

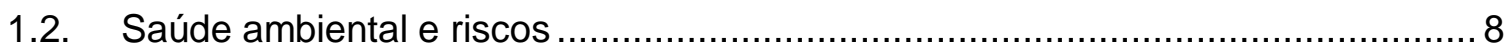

1.3. Saúde ambiental e a nova agenda de pesquisa ............................................ 11

1.3.1. A questão ambiental: substrato para a construção da área da saúde

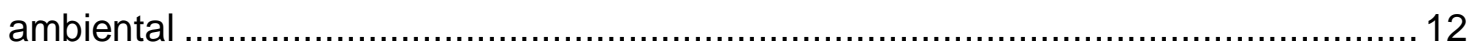

1.3.2. Ecossaúde, uma abordagem para a investigação da saúde ambiental ....... 16

1.3.3. Algumas perspectivas teóricas da Ecossaúde ........................................ 18

1.3.3.1. Contribuições da noção de "sistema socioecológico complexo" .............. 19

1.3.3.2. A teoria dos sistemas e a abordagem da ecossaúde............................. 20

1.3.4. A operacionalização da pesquisa na abordagem da ecossaúde .................2 21

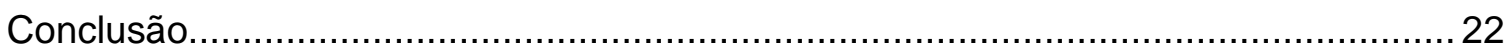

\section{Capítulo 2. CICLO DE VIDA DA FRONTEIRA: QUE RELAÇÃO COM O MEIO}

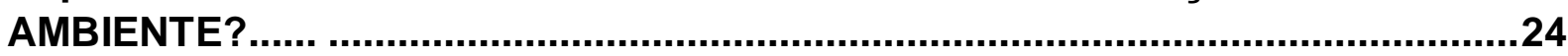

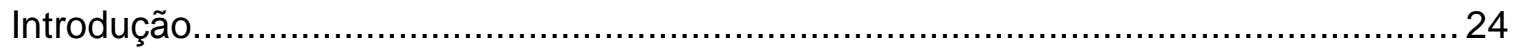

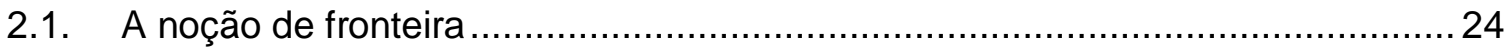

2.2. A fronteira vista como um sistema em evolução: considerações preliminares .... 26

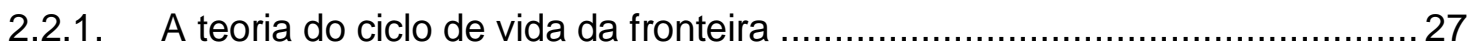

2.2.2. O ciclo de vida e as transformações do meio ambiente................................28

2.2.2.1. Pré-fronteira: espaço virgem .......................................................... 29

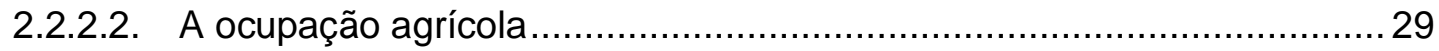

2.2.2.3. O avanço da fronteira agrícola, a degradação e a questão ambiental ....30

2.2.2.4. Diferenciação, integração e a nova configuração ambiental ................... 33

2.2.3. A contaminação tóxica do meio ambiente .............................................. 36

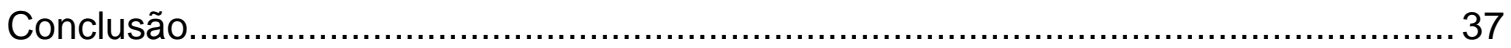

\section{Capítulo 3. MEIO AMBIENTE E SAÚDE NA FRONTEIRA: QUE}

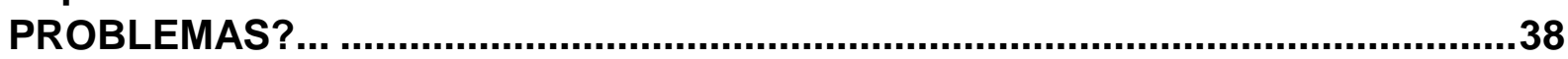

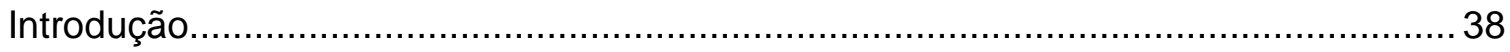

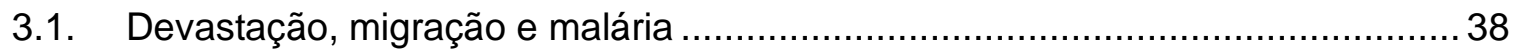


3.2. Queimadas e doenças respiratórias 42

3.3. Queimadas e doenças cardiovasculares ...................................................... 44

3.4. Agrotóxicos, metais pesados e doenças neurodegenerativas ........................... 46

3.4.1. Agrotóxicos e doença de Parkinson ...................................................... 47

3.4.2. Mercúrio, mal de Alzheimer e doença de Parkinson.................................. 49

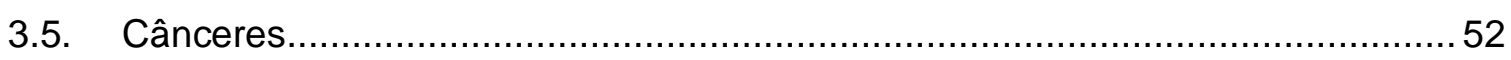

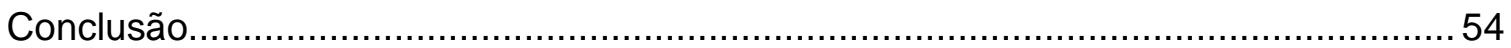

\section{Capítulo 4. CARACTERIZAÇÃO DA ÁREA DE ESTUDO: OCUPAÇÃO E} DEGRADAÇÃO AMBIENTAL EM ALTA FLORESTA ......................................56

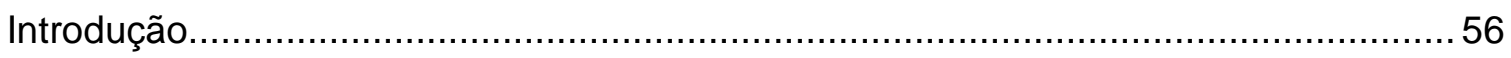

4.1. Contextualização histórica: A ocupação de Alta Floresta .................................56

4.1.1. A ocupação e a expropriação indígena ................................................ 56

4.1.2. A dinâmica da ocupação da fronteira agrícola de Alta Floresta ................... 57

4.1.3. O projeto Alta Floresta: do "ideal" ao concreto .......................................60 60

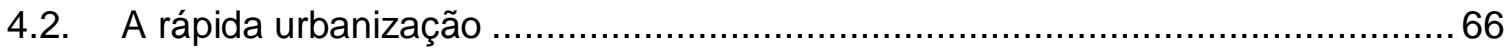

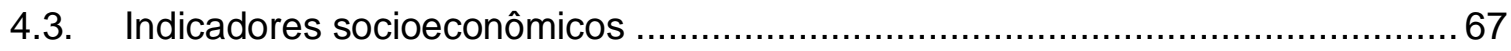

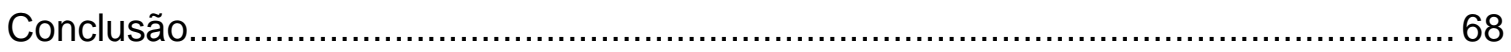

\section{Capítulo 5. DELINEAMENTO DO ESTUDO: A RELAÇÃO ENTRE A} DEGRADAÇÃO AMBIENTAL E A SAÚDE NA FRONTEIRA................................70

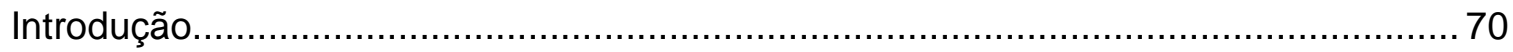

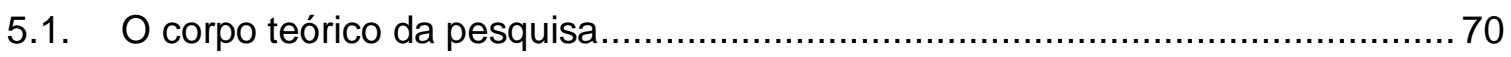

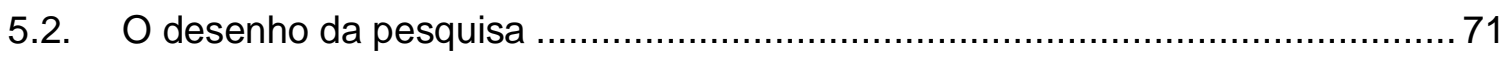

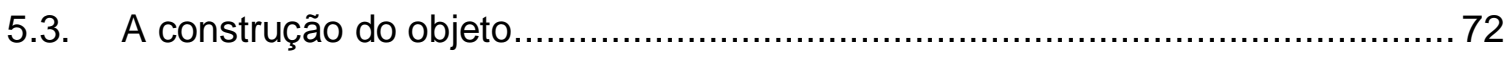

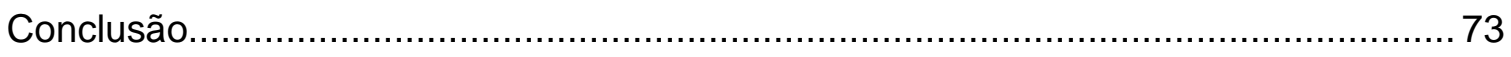

Capítulo 6. MÉTODO ....................................................................................74

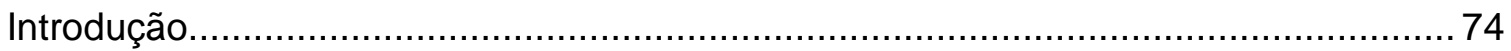

6.1. Um método centrado na abordagem ecossistêmica ..................................... 74

6.2. Os grupos focais: uma técnica para a coleta de dados ................................ 76

6.3. A primeira etapa de campo: explorando as primeiras informações, encontrando

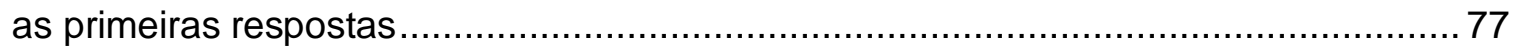

6.3.1. Primeira fase: Entrevistas abertas e conversas livres............................... 78

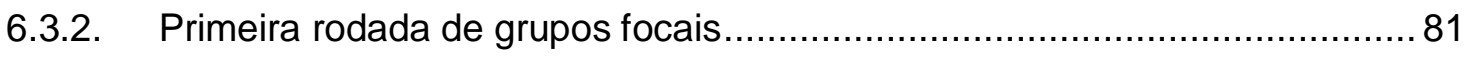

6.3.3. Segunda rodada de grupos focais ...................................................... 86

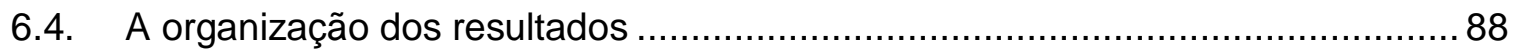


6.5. Alguns limites do método e os meios para superá-los 89

Conclusão 90

\section{Capítulo 7. FRONTEIRA AGRÍCOLA EM ALTA FLORESTA: FORMAS DE} USO E OCUPAÇÃO DO ESPAÇO E TRANSIÇÃO DE DOENÇAS. 92

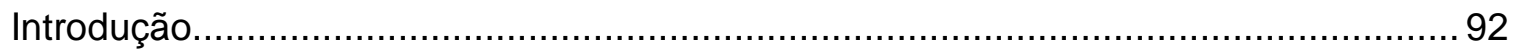

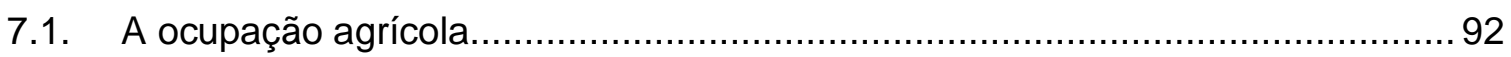

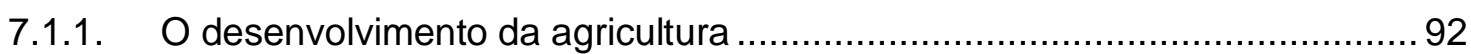

7.1.2. Entre a agricultura e o garimpo de ouro .................................................. 93

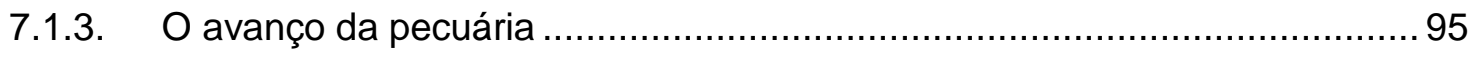

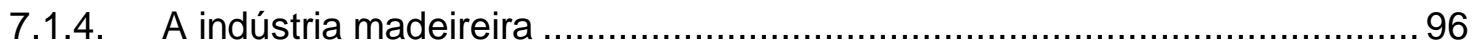

7.1.5. A chegada das grandes obras de infraestrutura e das lavouras de soja......97

7.1.6. O avanço da fronteira em fases ............................................................. 98

7.2. O avanço da fronteira e a transição das doenças: das infecções aos agravos

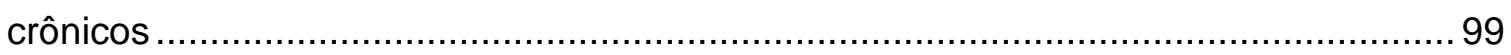

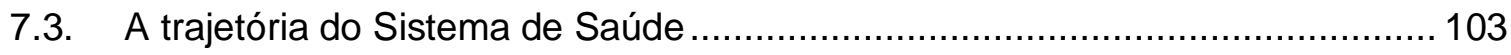

7.3.1. A SUCAM, as doenças infectoparasitárias e os equívocos de abordagem 104

7.3.2. Um novo modelo para a saúde: avanços e limites do SUS em Alta Floresta 107

Conclusão 109

\section{Capítulo 8. DEGRADAÇÃO BIOFÍSICA DO MEIO AMBIENTE E RISCOS À SAÚDE NO CONTEXTO DA FRONTEIRA AGRÍCOLA DE ALTA FLORESTA: DOENÇAS INFECTOPARASITÁRIAS}

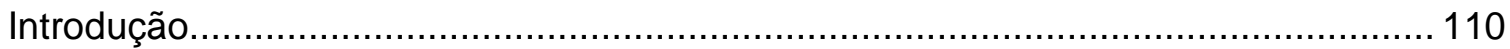

8.1. O avanço da ocupação e a degradação biofísica do meio ambiente .................110

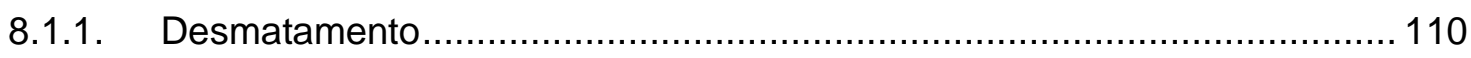

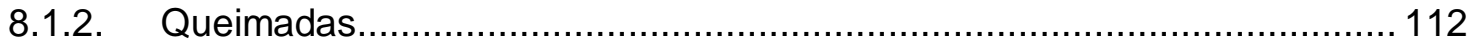

8.1.3. A reviravolta da degradação biofísica do meio ambiente...........................113

8.1.4. A degradação biofísica e o momento atual............................................. 116

8.2. Riscos à saúde associados ao desmatamento ............................................. 117

8.2.1. A alta exposição a mosquitos ............................................................. 117

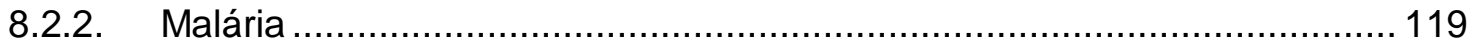

8.2.2.1. A emergência da doença ............................................................. 119

8.2.2.2. O controle da epidemia ................................................................. 122

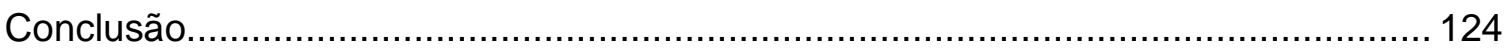


Capítulo 9. CONTAMINAÇÃO TÓXICA DO MEIO AMBIENTE E RISCOS À SAÚDE NO CONTEXTO DA FRONTEIRA AGRÍCOLA DE ALTA FLORESTA: DOENÇAS CRÔNICAS

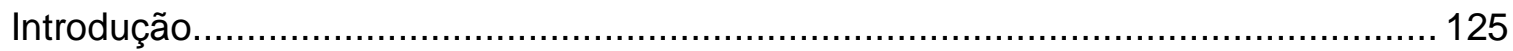

9.1. O uso do fogo e o risco para as doenças respiratórias ...................................... 125

9.2. Doenças respiratórias: um mal de fronteira ………………......................... 127

9.3. Contaminação tóxica do meio ambiente e o aumento do risco para doenças

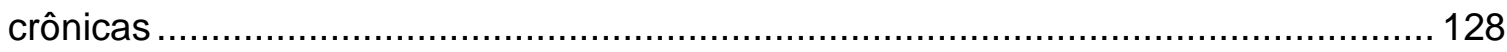

9.3.1. Formas de contaminação tóxica do meio ambiente e riscos associados .......131

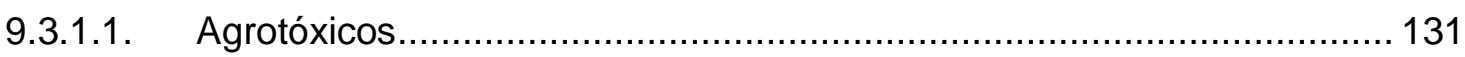

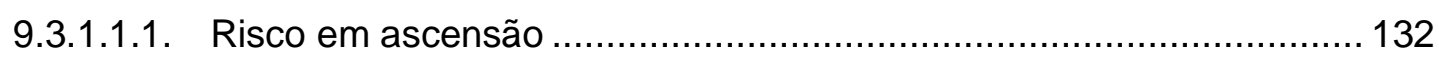

9.3.1.1.2. Outras fontes de contaminação ambiental por agrotóxicos................. 133

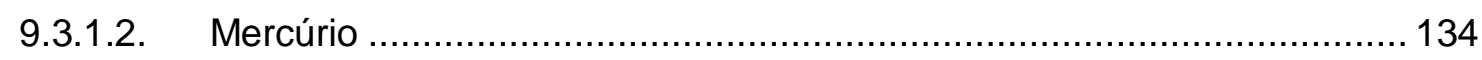

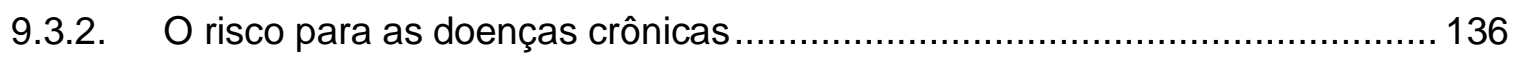

9.3.2.1. Doenças cardiovasculares: como identificar as causas? ...................... 136

9.3.2.2. Cânceres: A exposição a contaminantes ambientais e o aumento da frequência da doença ....................................................................................... 137

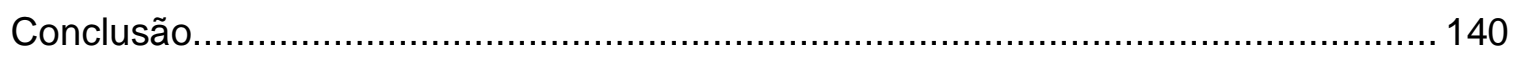

CONSIDERAÇÕES FINAIS ....................................................................142

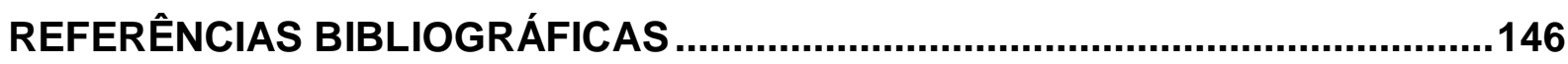

ANEXO I - ROTEIRO PARA AS ENTREVISTAS …..........................................

ANEXO II - TERMO DE CONSENTIMENTO LIVRE E ESCLARECIDO..................172

ANEXO III - SÍNTESE DOS RESULTADOS …................................................173 


\section{INTRODUÇÃO GERAL}

Apesar da importância da degradação ambiental provocada pelo avanço da fronteira agrícola na Amazônia, apenas recentemente o problema passou a ser abordado sob a ótica da questão ambiental ${ }^{1}$ (ALBALADEJO; ARNAULD DE SARTRE, 2005; BECKER, 2005b). Esta nova abordagem tem origem nas denúncias dos movimentos ambientalistas que ecoaram pelo mundo a partir dos anos 1960. Ela traz, em si, além da demanda global de uma revisão das estratégias de desenvolvimento, uma ressignificação da percepção da natureza. Não se trata mais de um bem natural, situado fora do escopo da ação humana (GIDDENS, 1997). Mas, ao contrário, a natureza é hoje percebida como um bem que foi, ao longo dos últimos séculos, absorvido e transformado pelo sistema tecnológico-industrial (BECK, 2010).

Esta outra perspectiva impõe novos desafios às disciplinas científicas. Nas ciências da saúde, por exemplo, emergem questões como: Quais são as consequências da "exposição humana a substâncias químicas e outros processos destrutivos" gerados pela globalização da agricultura? (BREILH, 2008, p. 176). Como a "expansão da fronteira agrícola e o investimento na monocultura extensiva" afetam a saúde das populações? (FINKELMAN; FRANCO NETTO; GALVÃO, 2002, p. 14). Quais são os efeitos diretos e indiretos do "amplo processo de conversão de áreas de florestas em áreas agrícolas, e as alterações nos ecossistemas e perda da biodiversidade que the acompanharam", "sobre a saúde e o bemestar das gerações presentes e futuras"? (FREITAS; PORTO, 2006, p. 67).

A fronteira agrícola constitui um movimento de ocupação demográfica e econômica de um território (BECKER, 1988). Esse movimento processou-se, na Amazônia brasileira, em fases características: agricultura familiar, extrativismo madeireiro e mineral, pecuária extensiva e monocultura de soja (SAYAGO; TOURRAND; BURSZTYN, 2004). Durante estas fases, pôs-se em curso uma dinâmica acelerada de desmatamento, queima da biomassa florestal e aumento da contaminação dos ecossistemas com resíduos de mercúrio e agrotóxicos.

No curso do avanço da fronteira agrícola, como a degradação ambiental afetou a saúde da população local? Sob o ponto de vista da saúde pública, quais são as tendências atuais da fronteira? São estas as questões que nos desafiaram a desenvolver este estudo. Trata-se de uma investigação de caráter sistêmico e participativo, sobre o perfil epidemiológico de uma população em função da degradação ambiental. O campo de estudo

\footnotetext{
${ }^{1}$ A questão ambiental diz respeito à consciência ecológica, criada e disseminada a partir da percepção das ameaças geradas pelo desenvolvimento científico-tecnológico e industrial (ALET; DESAILLY; VERGNOLLE-MAINAR, 2005; GIDDENS, 1997).
} 
é a fronteira agrícola de Alta Floresta, localizada ao Norte do Estado de Mato Grosso. Esta região foi ocupada depois da década de 1970, a partir de um projeto privado de colonização. O município constitui-se de uma área de 8.976,177 Km² ocupada, atualmente, por cerca de 50 mil habitantes (IBGE, 2014a). A principal atividade econômica é a pecuária extensiva de corte e leite, cujo efetivo bovino foi estimado recentemente em aproximadamente 850 mil cabeças (IBGE, 2014b).

Em termos ambientais, a história desta fronteira agrícola pode ser dividida em duas partes. Na fase de ocupação, uma série de incentivos fiscais determinaram a derrubada da floresta e sua conversão em área agrícola. O resultado foi uma degradação que atinge, nos dias atuais, cerca de 70\% da área florestal municipal (BERNASCONI; ADAB; MICOL, 2008; INPE, 2014a). No período mais recente, um conjunto de medidas governamentais pressiona os grupos econômicos e o setor público local a controlar o desmatamento e a adaptar a atividade agropecuária a uma matriz mais sustentável (BECKER, 2009). Nos últimos cinco anos (2009-2014), a queda nas taxas de desmatamento e queimadas aproximou-se de $100 \%$ (INPE, 2014a, 2014b). Adicionalmente, vem sendo incrementadas algumas iniciativas de cadastramento ambiental rural (CAR) e recuperação de áreas de proteção permanente (APPs) que introduzem novas perspectivas em termos de desenvolvimento regional (GONÇALVES, 2014; SASSAKI, 2014).

Em ritmo similar, o perfil epidemiológico passou, ao longo do avanço da fronteira, de uma fase de alta disseminação de malária, que caracterizou uma das mais importantes epidemias da história brasileira (CASTRO et al., 2006; KATSURAGAWA et al., 2008), para a uma fase de maior prevalência das doenças crônicas. No caso da asma infantil, por exemplo, no início dos anos 2000, o município era considerado um dos de maior risco para a doença de toda a América Latina (FARIAS et al., 2010). Os agravos respiratórios, como um todo, respondiam, à época, por mais de $80 \%$ das internações hospitalares de crianças (IGNOTTI et al., 2007).

Este contexto nos leva a questionar a relação entre a degradação do meio ambiente e a emergência das doenças de maior importância em termos de saúde pública. Em um contexto macro, a degradação ambiental influenciou o perfil epidemiológico? Como a população local compreende o problema?

O interesse pessoal em abordar esta questão advém da experiência profissional, decorrente de um conjunto de atividades de ensino e pesquisa, desenvolvido no Campus de Alta Floresta, da Universidade do Estado de Mato Grosso (UNEMAT). Entre 2008 e 2011, fomos responsáveis pela execução de dois projetos de pesquisa-ação ${ }^{2}$ e de um curso de

\footnotetext{
${ }^{2}$ A pesquisa-ação é um tipo de pesquisa social que integra atividades de intervenção. Tem como objetivos: (i) obter informações de difícil acesso e melhor conhecer reivindicações, representações,
} 
pós-graduação lato sensu em "Saúde e meio ambiente". Soma-se a este conjunto de experiências, o conhecimento sobre meio ambiente e interdisciplinaridade, apreendido durante o curso de doutorado e o estágio "sanduíche", realizado no CIRAD (Centro de Cooperação Internacional em Pesquisa Agronômica para o Desenvolvimento), em Montpellier, na França.

Os aportes teóricos que sedimentaram a pesquisa foram oferecidos pela área da saúde ambiental $^{3}$ (AUGUSTO, 2003; FISCHER; DODELER, 2009; MINAYO; CARVALHO, 2002; OPAS, 2011), da geografia (ALBALADEJO et al., 1996; BECKER, 2005b, 2009) e da sociologia ambiental (BECK, 2010; GIDDENS, 1991, 1997; HANNIGAN, 1995). Entre os conceitos que fundamentam o estudo estão: saúde, fronteira agrícola e meio ambiente.

Entendemos como meio ambiente, o resultado, observado nos ecossistemas, das transformações geradas pelas inovações científico-tecnológicas que acompanham o desenvolvimento agroindustrial (GIDDENS, 1997). Na fronteira agrícola, estas inovações ganham materialidade de acordo com as formas de uso e ocupação do espaço (agricultura, pecuária, mineração, etc.). Os danos ambientais, resultantes destes processos, distinguemse em duas categorias: degradação biofísica (desmatamento e queimadas) e contaminação tóxica dos ecossistemas (mercúrio, agrotóxicos, etc.).

A percepção das ameaças à saúde humana, produzidas por estas duas categorias de degradação ambiental, foi abordada como risco. Essas ameaças foram assim caracterizadas por: (i) serem produzidas pela ação humana e (ii) serem percebidas, pela população, como determinantes das doenças (BECK, 2010; GIDDENS, 1991, 1997).

O processo saúde-doença foi apreendido a partir de duas dimensões: (i) uma científica, que diz respeito aos valores médico-científicos, e (ii) outra social, que permeia as interpretações populares do discurso médico, construídas no interior da subjetividade dos grupos sociais (LAPLANTINE, 1991, 2001; MINAYO, 2006). Especificamente, o que interessou, neste caso, foi o perfil epidemiológico de uma população, e não a saúde dos indivíduos, de forma isolada.

Outra categoria que deu suporte à análise foi a noção de "ciclo de vida" da fronteira (ALBALADEJO et al., 1996; COY, 1996). Esta noção ajudou a apreender a evolução da relação entre a degradação ambiental e a emergência das doenças, observada no curso do avanço da ocupação agrícola. A fronteira agrícola, neste sentido, foi tratada, não como limite

capacidade de mobilização, etc.; (ii) contribuir para o melhor equacionamento possível do problema, com propostas de ações para a transformação da situação (THIOLLENT, 2005).

${ }^{3}$ A saúde ambiental é uma área do conhecimento criada no século XVIII para investigar a relação entre a saúde é a insalubridade do meio. Ela se renova, a partir do aparecimento da questão ambiental, na década de 60 do século passado (CABANES; ROUSSEL, 2010). Nos dias de hoje, configura-se como uma área interdisciplinar dedicada à investigação dos efeitos da degradação ambiental sobre a saúde. 
geográfico ou político entre países, mas como espaço em processo de ocupação e anexação econômica ao território nacional (BECKER, 1988). Nela, a apropriação dos recursos naturais e o desenvolvimento da agropecuária conjugam a principal força econômica. É também, nela, que o discurso ambientalista internacional, em relação à Amazônia, provoca as mais expressivas transformações recentes (BECKER, 2005b).

Em termos empíricos, alicerçamos a investigação nas bases metodológicas oferecidas pela ecossaúde (Abordagem ecossistêmica para a saúde humana) (CHARRON, 2012; KAY et al., 1999; LEBEL, 2003; WALTNER-TOEWS, 2001). Trata-se de um enfoque sustentado pela Teoria dos Sistemas (BERTALANFFY, 1975), que se diferencia, por um lado, pela valorização da participação social na pesquisa. Por outro, por oferecer as bases para a análise e a discussão dos resultados da pesquisa de forma sistêmica (valorizando as conexões entre as diferentes dimensões do problema).

Nesta perspectiva, a pesquisa de campo foi orientada por um método conhecido como AMESH (Metodologia Adaptativa para a Sustentabilidade do Ecossistema e da Saúde) (WALTNER-TOEWS et al., 2004). Ele fundamentou, entre outras coisas, o diagnóstico participativo, a reconstrução histórica do problema e a análise dos resultados.

As informações de campo foram coletadas por meio de duas técnicas: "grupo focal" (focus group) (CARLINI-COTRIM, 1996; TRAD, 2009) e "linha do tempo" (timeline) (CHAMBERS, 1994). Elas permitiram apreender os pontos de vista de grupos sociais, sob a forma de concepções, opiniões e interpretações. Participaram da pesquisa, dois grupos distintos: (i) de profissionais da saúde, e (ii) de agricultores, trabalhadores rurais e exgarimpeiros. Os dados de campo foram complementados com entrevistas abertas e conversas livres (MINAYO et al., 2004).

O conjunto de percepções, apreendido em campo, foi analisado com a ajuda de resultados de pesquisas epidemiológicas desenvolvidas na região (FARIAS et al., 2010; HACON et al., 1997a, 1997b, 2006; IGNOTTI et al., 2010b; LACERDA; DE SOUZA; RIBEIRO, 2004; MAENHAUT et al., 2002). As discussões mostram alguns padrões e tendências da evolução da relação entre a degradação ambiental e a transição epidemiológica, nesta fronteira. Não se oferecem respostas acabadas, mas pistas que contribuem para melhor compreender a participação do meio ambiente na definição do perfil epidemiológico de uma população de fronteira.

A tese se divide em três partes. Cada uma delas possui três capítulos. A primeira parte apresenta o quadro teórico e o contexto da problemática ambiental e da saúde nas fronteiras agrícolas. $\mathrm{O}$ primeiro capítulo faz alusão à abordagem ambiental da saúde. $\mathrm{O}$ segundo aborda o "ciclo de vida" da fronteira e suas consequências ambientais. O terceiro 
trata da participação do meio ambiente na origem das doenças de maior importância nas fronteiras agrícolas.

$\mathrm{Na}$ segunda parte, é caracterizada a área de estudo e se delimita a pesquisa. No capítulo quatro, são abordados os processos que geraram a ocupação agrícola do município de Alta Floresta. No quinto capítulo são apresentados os objetivos, as questões e as hipóteses que orientam o estudo. O capítulo seis traça as linhas principais dos métodos mobilizados na etapa de campo: as técnicas, os critérios, as etapas e os limites do estudo.

$\mathrm{Na}$ terceira parte, são analisados e discutidos os resultados de campo. O capítulo sete trata do perfil epidemiológico encontrado na fronteira de Alta Floresta. O capítulo oito define a importância da degradação biofísica do meio para a emergência da malária e o nove, trata da relação entre a contaminação tóxica do meio ambiente e a emergência das doenças crônicas.

As considerações finais realçam a importância da degradação do meio ambiente para a definição do perfil epidemiológico de Alta Floresta. Em linhas gerais, os resultados do estudo mostram que, nesta fronteira, foram as formas de uso e ocupação do espaço orientadas, sobretudo, pelo pacote tecnológico disseminado pela "Revolução Verde" - que determinaram os principais riscos à saúde. Este quadro foi potencializado, entre outros fatores, pelo baixo nível de percepção individual dos riscos e os equívocos de abordagem do sistema de saúde.

Dentre as perspectivas apontadas pelo estudo, destacam-se a necessidade de uma reconfiguração dos sistemas de produção agrícola, sobretudo no que concerne à gestão do consumo de agrotóxicos e o controle sobre a exploração de novas terras amazônicas. Além disso, vale salientar, a importância da inclusão de novas orientações no sistema de saúde, que levem em conta a distinção dos riscos contemporâneos, em termos de invisibilidade, cronicidade e irreversibilidade. Sob o ponto de vista da pesquisa científica, estas novas demandas requerem a inclusão de abordagens como a história de vida dos doentes e a representação social da relação meio ambiente e saúde. 
- Primeira Parte -

MEIO AMBIENTE E SAÚDE EM REGIÕES DE FRONTEIRA AGRÍCOLA 


\section{Capítulo 1. MEIO AMBIENTE E SAÚdE: PERSPECTIVAS DE UMA ÁREA EMERGENTE}

\section{Introdução}

Este é o primeiro, de uma série de três capítulos que marcam a estrutura teórica que sustenta a tese. O objetivo desses capítulos é situar, sob o ponto de vista teórico, as noções de processo saúde-doença, meio ambiente e fronteira agrícola, adotadas no estudo.

Ao longo deste primeiro capítulo, apresentamos os elementos que embasaram a constituição da área da saúde ambiental e que subsidiam, no contexto deste estudo, a construção do objeto, a pesquisa empírica e a análise dos resultados. Neste sentido, destacamos a importância da questão ambiental, como fenômeno que contribuiu para uma importante reconfiguração dos estudos do meio ambiente e da saúde. Adicionalmente, marcamos algumas das transformações ocorridas, mais recentemente, no campo da pesquisa científica, sobretudo no que concerne à interdisciplinaridade e a participação social nas pesquisas.

\subsection{Breve introdução ao estudo da saúde humana}

As ciências da saúde se dividem em duas partes: a medicina individual e a saúde coletiva. Na perspectiva individual, a doença é o principal objeto de investigação e prática. Ela é tratada como um processo biológico, ou seja, um desequilíbrio orgânico. Os principais objetivos são o controle da doença, a reabilitação do doente e a minimização de sua dor. Os meios usados para atingir esses objetivos são, sobretudo, os diagnósticos clínicos e os tratamentos terapêuticos.

A área da saúde pública, por sua vez, se debruça sobre os determinantes históricos, subjacentes às causas das doenças, algo como "a causa das causas"4. A doença é compreendida, neste sentido, como a expressão corporal das condições impostas pela sociedade, tais como alimentação deficiente, analfabetismo ou baixo nível de escolaridade, desigualdade social, condições desfavoráveis de trabalho, restrições de acesso a serviços de saúde e saneamento, exposição a contaminantes químicos ou nucleares (CAPONI, 1997).

Entende-se, nesta perspectiva, que por detrás da manifestação biológica, esconde-se um processo social (LAURELL, 1982). Ele se revela de acordo com a inserção do grupo nos

\footnotetext{
${ }^{4}$ Abordada como "determinação social da saúde" (DSS).
} 
processos de produção (condições de trabalho), consumo e reprodução da sociedade (estrutura de classes) (ALMEIDA FILHO, 2009). Por exemplo, as doenças infecciosas, parasitárias ou nutricionais são mais comuns nos grupos de baixa renda (BARATA, 2009). Da mesma forma, trabalhadores da indústria ou da agricultura se distinguem pela maior probabilidade de desenvolver certas doenças crônicas e traumáticas que outros grupos populacionais (BRASIL; OPAS, 2001). O ato de adoecer ou estar saudável, neste sentido, é interpretado como um produto da sociedade.

As pesquisas que se inserem nesta abordagem têm como foco as coletividades humanas. Elas apreendem a dimensão social e/ou ambiental do processo saúde-doença e são desenvolvidas, sobretudo, na área da epidemiologia. Naturalmente, os dados das pesquisas não são essencialmente os diagnósticos clínicos ${ }^{5}$, pelo menos não em primeira instância. Utilizam-se indicadores, tais como esperança de vida ao nascer, condições nutricionais, características do trabalho ou ocorrência e distribuição de doenças transmissíveis e não-transmissíveis. É frequente a análise de $\operatorname{taxas}^{6}$ de morbidade (adoecimento) e mortalidade. A partir delas, identificam-se padrões e tendências e se busca explicações para os processos que determinam as doenças. Além dos processos sociais, as pesquisas também se dedicam à compreensão da participação da degradação ambiental na determinação da saúde.

\subsection{Saúde ambiental e riscos}

As bases da saúde ambiental foram oferecidas pelo higienismo europeu do século XVIII. Tratava-se de uma abordagem neo-hipocrática ${ }^{7}$ da relação ambiente-indivíduo, baseada na noção de salubridade e insalubridade como estado do meio que poderia favorecer ou, ao contrário, prejudicar a saúde. Esta concepção sofreu readequações a partir da incorporação da questão ambiental, trazida à tona pelo movimento ambientalista dos anos 1960/70 (CABANES; ROUSSEL, 2010). O estudo dos fenômenos localizados de

\footnotetext{
${ }^{5} \mathrm{O}$ que ocorre apenas para notificação de casos.

6 As taxas referem-se ao número de doenças (morbidade) ou mortes (mortalidade) em uma determinada população conhecida e num período definido. Por exemplo, a prevalência da malária em uma determinada população, durante um determinado período, é medida em número de casos em cada 1.000 habitantes.

${ }^{7}$ Trata-se de uma releitura da abordagem hipocrática da saúde, fundada por Hipócrates de Cós (460377 a.C.). Hipócrates foi um famoso médico grego, considerado, por muitos, como o "pai da medicina". Os textos produzidos por sua escola se tornaram conhecidos por volta de 300 a.C. São 53 tratados com os ensinamentos sobre epidemias, articulações e fraturas. O texto "Ares, águas, lugares", o mais conhecido, discute os fatores ambientais ligados à doença, defendendo um conceito ecológico de saúde-enfermidade (SCLIAR, 2007). A principal característica desta abordagem era a ideia da saúde como o equilíbrio entre o homem e a natureza.
} 
contaminação biológica, essencialmente ligada à higiene, foi ampliado para pesquisas que tratam da degradação ambiental e da contaminação de origem agroindustrial.

Neste contexto, a saúde ambiental é interpretada a partir de duas dimensões: (i) teórica, usada como indicador da qualidade das relações ambiente-saúde, e (ii) metodológica, uma técnica articuladora, suscetível à articulação de variadas disciplinas científicas e do conhecimento informal. Este tipo de abordagem leva em conta a complexidade das interações entre a saúde das populações e o ambiente em que as populações vivem e trabalham. As mudanças ambientais, que acompanham a história de um lugar específico, podem ser relacionadas às mudanças percebidas na saúde coletiva (FISCHER; DODELER, 2009).

Direta ou indiretamente, as pesquisas da saúde ambiental abordam os riscos. Contudo, poucas vezes é clara a distinção entre "fatores de risco" e "riscos" (BREILH, 2006). Os "fatores de risco" se referem às potenciais ameaças e perigos que podem causar danos ou prejuízos à saúde humana. De forma geral, estas ameaças são passíveis de diagnóstico físico, químico, biológico, entre outros. Alguns exemplos são os sistemas de controle da qualidade da água, do ar ou dos alimentos, usado para prevenir a propagação de doenças entre as populações.

Os riscos, por sua vez, surgiram com o processo de constituição das sociedades modernas, entre os séculos XV e XVIII, e se legitimaram na atual fase de desenvolvimento da sociedade. Trata-se de ameaças de diferentes níveis e categorias que, com a disseminação do conhecimento científico, passaram a ser percebidas pela população exposta (BECK, 2010; GIDDENS, 1991, 1997). O risco apresenta, portanto, duas dimensões importantes: (i) o fato de o risco ser gerado por formas "modernas" de degradação (desmatamento, contaminação tóxica, por exemplo) e (ii) o fato dele ser percebido pela população, como potencial ameaça à saúde.

Entretanto, é preciso lembrar que a percepção dos riscos é limitada. A maioria dos produtos usados pela agroindústria, por exemplo, apresenta fórmulas físico-químicas sensorialmente imperceptíveis (BECK, 2010). Embora a sua presença seja identificada, a dimensão real da ameaça foge da percepção dos trabalhadores e consumidores a eles expostos.

O alcance dos riscos é global (GOLDBLATT, 1996). A globalização das cadeias alimentares os universaliza. Os pesticidas presentes em um produto agrícola, por exemplo, geram ameaças à saúde não somente na região produtora, mas, também, no lugar em que o alimento é consumido. De forma semelhante, também os gases tóxicos emitidos pelos incêndios florestais se dissipam para além do espaço em que são produzidos. De uma queimada na Amazônia, por exemplo, as emissões gasosas podem seguir o padrão de 
circulação atmosférica, sair do continente Sul Americano e atingir regiões como a do Caribe (ARTAXO et al., 2005).

Em tese, estamos todos expostos. Entretanto, o nível de exposição não é equivalente para todos. Alguns grupos são mais vulneráveis que outros. Isso porque a distribuição dos riscos ambientais obedece, em última instância, à lógica das ameaças sociais. Populações mais pobres trabalham e vivem em ambientes que oferecem maior risco (CORVALÁN; KJELLSTRÖM; SMITH, 1999). No trabalho agrícola ou industrial, por exemplo, os riscos de sobrecarga, irradiação e contaminação são distribuídos conforme a profissão. Além disso, os grupos de menor renda geralmente habitam as redondezas dos centros de produção industrial, onde "são onerados ao longo do prazo por conta de diversos poluentes no ar, na água e no solo" (BECK, 2010, p. 42). Mesmo no caso dos riscos relacionados ao evento das mudanças climáticas como os desastres naturais e as doenças infecciosas, tais populações continuam sendo as mais propensas ao adoecimento e morte, devido à sua vulnerabilidade social (BARCELLOS et al., 2009).

Os produtos industriais apresentam um importante nível de toxicidade. No que refere à saúde humana, o efeito desses compostos tende a ser cumulativo e, em alguns casos, irreversível (BECK, 2010). As implicações, para o organismo, da longa exposição a agrotóxicos, por exemplo, quando se manifestam, tendem a ser crônicas, afetando, sobretudo, os sistemas neurológicos e endócrinos - produtores de hormônios associados à infertilidade, entre outros - ou produzindo cânceres. São doenças que geram baixa mortalidade, se as taxas forem comparadas com as doenças infecciosas. No entanto, os seus efeitos reduzem significativamente a qualidade de vida do doente, sobretudo entre as pessoas idosas.

As doenças crônicas, resultantes da exposição à poluição do ar, solos, água e alimentos, tendem a manifestar-se tardiamente, dificultando, na maior parte dos casos, a identificação precisa de sua causa. No caso das populações das fronteiras agrícolas da Amazônia, por exemplo, pesquisas buscam encontrar a relação entre doenças cardiovasculares - hipertensivas e cardíacas - e a exposição a contaminantes atmosféricos, derivados das queimadas florestais (NUNES; NEVES; IGNOTTI, 2013; NUNES; IGNOTTI; HACON, 2013). Contudo, devido ao longo período de exposição humana, aos diferentes níveis de concentração dos poluentes no ar e à existência de outros riscos, as pesquisas encontram limites em confirmar a associação entre as doenças e a poluição. Assim, a taxa ascendente de mortes por estas doenças acaba sendo creditada, na maior parte das vezes, ao envelhecimento da população e aos estilos de vida, como o alto consumo de sal e gordura, por exemplo. 
A incorporação da noção de risco nos estudos de saúde ambiental é bastante recente e muito ainda há por se descobrir e desenvolver. Isto porque a percepção da complexidade dos riscos, de seu comportamento no ambiente e de seus efeitos para a saúde, impõe grandes desafios. Neste sentido, é consenso que uma abordagem mais ampla dos riscos exige uma série de inovações na ciência, sobretudo no que diz respeito à compreensão das diversas articulações, próximas e distantes, dos fatores que os geram. Estes são alguns dos desafios que engendraram este estudo.

\subsection{Saúde ambiental e a nova agenda de pesquisa}

De forma abrangente podemos dizer que a noção de risco adentra os estudos de saúde ambiental como suporte para compreender como a saúde coletiva se comporta em função das múltiplas formas da degradação ambiental contemporânea. Um grande número de pesquisas aborda a relação entre a exposição a determinados riscos e os problemas emergentes de saúde, como as doenças crônico-degenerativas (cânceres, doenças cardiovasculares, neurológicas e respiratórias, dentre outras). Ao mesmo tempo, investe-se no conhecimento das ameaças de reemergência ou recrudescência de certas doenças infecciosas, como malária e dengue, relacionadas, por exemplo, às mudanças climáticas. Em todas as suas formas, as doenças são analisadas em função da exposição da população, que delas padece, a contaminantes industriais, à degradação física do meio ambiente e suas consequências locais e globais (desmatamento, efeito estufa, remoção da camada de ozônio, mudança do clima, etc.).

Destacam-se pesquisas que se dedicam ao estudo de eventos específicos, como do acidente de Bhopal, na Índia, em 1984, onde gases tóxicos, emitidos acidentalmente por uma fábrica de pesticidas, intoxicaram milhares de pessoas. Mas, também, de problemáticas históricas, como a exposição dos trabalhadores a agrotóxicos em campos de produção de flores, nas Províncias de Cayambe e Tabacundo, no Equador (BREILH et al., 2005). No caso brasileiro, é exemplo o projeto CARUSO (Contaminação e exposição ao mercúrio na Amazônia), que investiga a exposição de comunidades ribeirinhas amazônicas ao mercúrio, natural dos solos da Amazônia e deles lixiviado por meio de práticas agrícolas (GUIMARÃES; MERGLER, 2011).

O caso da presença de resíduos de agrotóxicos no leite materno, em Lucas do Rio Verde, no Mato Grosso, investigado por Pignati, Machado e Cabral (2007) e amplamente veiculado pela mídia entre os anos de 2007 e 2008, é outro exemplo emblemático. A problemática da saúde ambiental contempla, neste sentido, os riscos ambientais produzidos pela sociedade moderna e que, embora possam contemplar as contaminações biológicas 
têm, em sua maioria, caráter tecnológico. Agrotóxicos, ondas eletromagnéticas, metais pesados, amianto, tinturas de tecidos, polipropileno ${ }^{8}$, entre outras substâncias potencialmente nocivas à saúde humana, integram as agendas de pesquisa.

Muitos projetos de pesquisa debruçam-se, entre outros, sobre a poluição atmosférica, doenças infecciosas e estudos toxicológicos e de saneamento ambiental. Essa categoria de pesquisas tem ajudado a compreender, por exemplo, a relação entre o volume de queimadas e a alta prevalência de doenças respiratórias e cardiovasculares, nas fronteiras agrícolas amazônicas brasileiras (CARMO et al., 2010; IGNOTTI et al., 2010a).

Em termos gerais, as pesquisas de caráter inter ou transdisciplinar tendem a mobilizar a Teoria dos Sistemas e se organizar em torno de projetos que investigam e, ao mesmo tempo, produzem intervenções sociais. Esta abordagem é fruto de uma longa construção teórica, baseada na biologia e na física e respaldada pelas noções de sistema aberto e fechado e auto-organização, entre outros. Um de seus desdobramentos é a incorporação da ideia de evolução dos sistemas, ou seja, a compreensão de que as leis da organização da vida são corrigidas por contínuas adaptações.

\subsubsection{A questão ambiental: substrato para a construção da área da saúde ambiental}

Chamamos de questão ambiental a emergência da preocupação internacional com a exaustão de recursos e a vulnerabilidade dos ambientes naturais (consciência ecológica). Ela toma força no fim dos anos 1960 e início dos 1970 em meio a uma série de denúncias sobre os danos ambientais provocados pelo desenvolvimento industrial, pós Segunda Guerra Mundial: chuva ácida, poluição do ar, destruição de habitats naturais, contaminação de rios e lagos, erosão de solos, degradação dos oceanos e das florestas, entre outros.

O reconhecimento da extensão e intensidade da crise ambiental, seu caráter transfronteiriço e a estreita relação com as questões socioeconômicas, levaram à rápida assimilação dos temas na agenda internacional (DUARTE, 2004). O substrato das discussões foi o relatório do Clube de Roma, intitulado "Limites ao Crescimento", e a realização da Conferência das Nações Unidas sobre o Meio Ambiente Humano (Conferência de Estocolmo), em 1972. Era o início de uma complexa fase de negociações e discussões internacionais em torno dos papéis dos diferentes países frente à problemática ambiental. Uma agenda que ganhou fôlego com a Rio-92, conferência histórica pela ampla participação de dirigentes políticos, mobilização de ONGs (Organizações Não Governamentais) e da sociedade civil. Esta agenda levou à inserção do debate ambiental no mundo dos negócios

\footnotetext{
${ }^{8}$ Um tipo de plástico, largamente empregado para armazenar alimentos e bebidas, e que tem sido associado a cânceres de fígado, próstata e mama.
} 
(BURSZTYN; BURSZTYN, 2012), que se fortaleceu com debate em torno da "economia verde", propagado na Rio+20, realizada em 2012, no Rio de Janeiro.

As primeiras denúncias sobre os efeitos de produtos industriais para a saúde foram realizadas por Rachel Carson, ainda na década de 1960, no livro Primavera Silenciosa (Silent Spring). A autora alertava para o imenso poder de degradação do meio ambiente adquirido pelo ser humano a partir do uso de pesticidas organoclorados ${ }^{9}$ nas lavouras agrícolas. As pesquisas mostraram que os seres vivos e a própria espécie humana estavam sendo contaminados com compostos extremamente tóxicos e persistentes no ambiente, como o DDT (diclorodifeniltricloroetano). Após décadas, os resíduos desses materiais podiam ser encontrados no solo, em peixes, pássaros, animais domésticos e selvagens e no próprio ser humano. "Eles aparecem no leite das mães, e, com toda probabilidade, também nos tecidos dos bebês ainda não nascidos", alertava Carson (1962, p. 26). Os perigos associados aos pesticidas, denunciados pela autora, abriram a discussão sobre as formas contemporâneas de degradação ambiental. O seu livro foi o estopim da explosão dos movimentos ambientalistas, os quais deram popularidade e força política à questão ambiental (DEBOURDEAU, 2013). A partir dos anos 1970, a notícia sobre os perigos para a saúde relacionados com a poluição industrial, de forma geral, e aos agrotóxicos e antibióticos, de modo particular, ganhou o mundo.

$\mathrm{Na}$ Conferência de Estocolmo, a saúde e o bem-estar humano foram usados como alerta para as graves consequências da transformação do meio ambiente e como justificativa para o cumprimento de metas globais de preservação e melhoria das condições ambientais. Os níveis de poluição da água, ar, terra e dos seres vivos e os grandes transtornos de equilíbrio ecológico da biosfera foram reconhecidos como importantes ameaças à saúde física, mental e social do ser humano (ONU, 1972). Por esta razão, o evento se tornou conhecido como o berço da nova área da saúde ambiental.

O documento do Clube de Roma, intitulado Relatório Brundtland - Nosso futuro comum -, publicado em 1987, também foi um importante difusor das ameaças do ambiente à saúde. Ele chamou a atenção para as numerosas mortes e sequelas deixadas pelos grandes desastres da época, como a explosão de tanques de gás liquefeito, no México, em 1984, e do reator nuclear de Chernobyl, em 1986. Além disso, o relatório alertava para o comprometimento da camada de ozônio, a elevação das temperaturas médias globais e o

${ }^{9}$ Os organoclorados estão entre os inseticidas de maior toxicidade já produzidos para uso agrícola. As suas características mais importantes são a prolongada persistência nos ecossistemas naturais, a mortandade de animais e o seu efeito carcinogênicos e endócrinos (hormonais) em humanos. Eles são hoje acusados de serem os principais agentes de doenças neurológicas entre os agricultores, como o mal de Parkinson. No Brasil, a mais importante deles, o DDT, teve seu uso agrícola proibido na década de 1980 . Outros tiveram sua estrutura química modificada e continuam sendo usados na agricultura. 
problema do lançamento de substâncias tóxicas no meio ambiente pela indústria e a agricultura (COMISSÃO MUNDIAL SOBRE O MEIO AMBIENTE E DESENVOLVIMENTO, 1988).

$\mathrm{Na}$ Rio 92 - Il Conferência das Nações Unidas sobre Meio Ambiente e Desenvolvimento Humano -, realizada em 1992, no Rio de Janeiro, as ameaças à saúde, produzidas pela pobreza e pelos problemas ecológicos, foram colocadas lado-a-lado. A Agenda 21 Global, um dos principais documentos resultantes da conferência, trouxe uma seção completa de programas e ações voltados para a redução dos problemas ambientais, como condição para a proteção e promoção da saúde humana (CONFERÊNCIA DAS NAÇÕES UNIDAS SOBRE MEIO AMBIENTE E DESENVOLVIMENTO, 1996).

Durante a Rio+20 - Conferência das Nações Unidas sobre Desenvolvimento Sustentável -, também realizada no Rio de Janeiro, em 2012, se questionava se os países pobres terão chance de crescer antes de ficarem "verdes" (CARTA CAPITAL, 2012). A dupla carga de problemas - sociais e ambientais - se tornava cada vez mais evidente. Como, ao mesmo tempo, lidar com os problemas sociais e as fontes de degradação do meio ambiente? Essas duas dimensões do mesmo problema sinalizavam a complexidade da questão ambiental e, em última instância, os desafios de compreender a sua relação com a saúde humana.

Assim, percebe-se que, embora a questão ambiental tenha sido identificada inicialmente como limitada pelas suas características técnicas (DUARTE, 2004) ou questionada devido à ameaça de o seu brilho ofuscar as demais questões sociais (STAHEL, 1994), no curso do tempo, ela se perpetuou como uma das maiores preocupações mundiais (BURSZTYN; BURSZTYN, 2006). Ao longo dos debates internacionais, a questão ambiental ganhou uma perspectiva ampla, provocando mudanças importantes nas áreas da política, da economia, da sociedade e da ciência (DUARTE, 2004). Em termos estruturais, a agenda multilateral e o progresso institucional, no que se refere à criação de ministérios, agências e organizações ambientais, em diversos países, estão entre os principais avanços das discussões (SACHS, 2000).

No campo da pesquisa científica, evoluiu um processo que produziu uma série de transformações em termos de abordagens, incluindo a construção de enfoques inter e transdisciplinares e a inclusão de abordagens sistêmicas. Nos dias de hoje, estas mudanças podem ser notadas, de forma mais efetiva, sobretudo nos projetos de gestão ambiental e desenvolvimento sustentável, aplicados a agrupamentos humanos de pequeno e médio porte (comunidades, vilarejos, aldeias, etc.). Em linhas gerais, sobressaem-se, neste contexto, três perspectivas importantes: (i) o esforço para a criação de uma dinâmica pautada no diálogo entre diferentes disciplinas científicas, (ii) a inclusão dos atores sociais 
na apreensão de informações e, por vezes, construção do conhecimento e (iii) o esforço conjunto (pesquisadores e atores sociais) em prol da implementação de mudanças, que visam minimizar ou mitigar o problema investigado (WEIHS; MERTENS, 2013).

Ainda no que se refere à ciência, a questão ambiental influenciou a construção de abordagens conceituais, em certos campos do conhecimento. A noção de meio ambiente, por exemplo, deslocou-se para uma perspectiva social. O meio ambiente passou a ser concebido como produto da sociedade, gerado pelo modelo de produção e consumo vigente na fase atual do desenvolvimento. Nesta composição, a pesquisas sobre o meio ambiente passaram a repousar, não apenas sobre a investigação do espaço, da fauna e da flora ou dos processos de degradação dos ecossistemas, mas, inclusive, sobre os problemas históricos, ulteriores a eles, produzidos pela interação sociedade-natureza (MENDONÇA, 2005).

$\mathrm{Na}$ visão atual, em parte das ciências, o meio ambiente é considerado uma construção social. Este é o principal aspecto que o contrapõe à noção de natureza. Em linhas gerais, natureza significa aquilo que ficou imperturbado, aquilo que foi criado independentemente da atividade humana. Se ela era determinada por decisões, estas não eram humanas. 0 meio ambiente é, ao contrário, a natureza completamente transfigurada pela intervenção humana (GIDDENS, 1997). O que se perpetua, a partir desta concepção é que, para a ciência, a natureza não mais existe, porque não existem mais espaços virgens. Independente da intensidade, todos os ecossistemas do planeta já foram alterados pela ação humana.

Esta mudança conceitual, no que tange ao meio ambiente, também pode ser percebida na evolução da área da saúde ambiental. Os estudos higienistas buscavam as respostas para as epidemias infecciosas no ambiente geográfico. As doenças estavam na natureza (CZERESNIA, 2001). Na orientação recente, os estudos incorporam fenômenos mais amplos e complexos, como, por exemplo, o desmatamento e os problemas ambientais presentes nas regiões e aglomerados urbano-industriais (FREITAS; PORTO, 2006). Eles abordam a natureza transformada pela ação humana.

Esse novo entendimento provocou certas mudanças na maneira de conduzir as pesquisas na área da saúde ambiental. Essas mudanças foram viabilizadas, entre outros fatores, pela adoção de abordagens sistêmicas. Os projetos passaram a valorizar a articulação de diferentes ciências (interdisciplinaridade). Ademais, trabalha-se, atualmente, na construção de técnicas que permitem abrir o processo de pesquisa à participação dos representantes da comunidade e outros atores (transdisciplinaridade) (LEBEL, 2003).

Neste sentido, algumas equipes de pesquisa, sobretudo das escolas canadenses, vem trabalhando na construção de um conjunto de técnicas que ajudam a operacionalizar as 
pesquisas na área da saúde ambiental. Trata-se da ecossaúde, uma abordagem que oferece elementos para a coleta coletiva de informações, de modo que os atores locais possam participar, de forma mais qualificada, do diagnóstico e da gestão dos problemas ambientais e da saúde. Adicionalmente, ela contribui para a análise integrada dos resultados de campo, privilegiando a interação entre os fatores observados.

\subsubsection{Ecossaúde, uma abordagem para a investigação da saúde ambiental}

Ecossaúde (Ecohealth) é um termo novo para a "abordagem ecossistêmica para a saúde humana" (Ecosystem Approach to Human Health), uma técnica metodológica que surgiu na década de 1970, em um programa de pesquisa desenvolvido na região dos Grandes Lagos, ecossistema compartilhado entre o Canadá e os Estados Unidos. O percurso da construção dessa abordagem nessa região é um bom exemplo para entender as características e o potencial deste enfoque para fundamentar a nossa pesquisa de saúde ambiental em uma fronteira agrícola.

A região dos Grandes Lagos cobre a fronteiras entre o Canadá e os Estados Unidos e é rodeada por importantes cidades industriais como Chicago, Cleveland, Hamilton e Toronto. Na década de 1970, esse ecossistema sofria as consequências da urbanização, industrialização e do acelerado crescimento da agricultura intensiva, pesca comercial e extrativismo florestal (RAPPORT, 1998; WALTNER-TOEWS; FERNANDES; BRICEÑOLEÓN, 2002). Eram problemas que iniciaram na década de 1910 e se potencializaram com o crescimento econômico do Pós-Guerra (MINAYO-GOMEZ; MINAYO, 2006). Várias tentativas de recuperação da qualidade da água, implementadas desde a década de 1940, vinham fracassando (U.S. ENVIRONMENTAL PROTECTION AGENCY, 2014).

No início dos anos 1970, a repercussão da questão ambiental e a mobilização dos cidadãos na luta contra a poluição e os processos predatórios pressionaram os governos. Em resposta, os dois países implantaram, em conjunto, um amplo programa de pesquisa que deveria resultar em um processo de gestão do meio ambiente e da saúde (FORGET; LEBEL, 2001). Na primeira fase, uma equipe interdisciplinar de pesquisadores produziu indicadores do estresse ambiental e dos efeitos da degradação ambiental sobre a saúde das populações (RAPPORT, 1998). Na segunda fase, os resultados foram compartilhados e discutidos com as comunidades locais. A evolução das discussões mostrou a necessidade de criar estratégias de gestão partilhada, geridas por conselhos técnico-consultivos. Esses mecanismos permitiram o monitoramento contínuo e a vigilância da qualidade da água. De lá para cá, segundo a agência norte-americana que organiza esse processo, $U$. $S$. Environmental Protection Agency (2014), a integridade química, física e biológica da bacia 
hidrográfica tem sido mantida. As pessoas continuam se envolvendo nos processos de decisão.

Este tipo de projeto de pesquisa se dedica a problemáticas localizadas, geralmente em aldeias, vilarejos bacias hidrográficas, bairros ou pequenas cidades (WEIHS; MERTENS, 2013). Do ponto de vista teórico, o objetivo é compreender as conexões entre a saúde humana e as perturbações do ecossistema. Investe-se, neste sentido, no reestabelecimento das conexões entre o meio ambiente e a saúde humana, trazendo para as discussões também os fatores sociais, econômicos e culturais inerentes ao ecossistema em estudo (FEOLA; BAZZANI, 2002). No plano da ação, se pretende desenvolver opções de gestão dos ecossistemas que reduzam os riscos à saúde humana, bem como, os custos econômicos das intervenções pós-danos (FREITAS et al., 2007).

Além da gestão das bacias dos Grandes Lagos, alguns outros projetos ecossistêmicos têm produzido resultados significativos em diferentes regiões. Em Katmandu, no Nepal, por exemplo, uma iniciativa de longo prazo, conduzida pela Universidade de Guelph, do Canadá, o Centro de Controle e Prevenção Doenças de Atlanta e a Universidade de Salford, da Inglaterra, permitiu a melhor compreensão da relação entre as práticas da agricultura urbana e a alta prevalência de uma zoonose ${ }^{10}$, transmitida por cães, entre a população pobre. O envolvimento dos atores locais no processo de avaliação do problema, planejamento e ação melhorou a compreensão da problemática ${ }^{11}$ e a capacidade de resolver as questões locais (PARKES et al., 2005; WALTNER-TOEWS et al., 2004, 2005; WEIHS; MERTENS, 2013).

$\mathrm{Na}$ Amazônia brasileira, uma iniciativa de características similares integra o projeto CARUSO $^{12}$, desenvolvido há 20 anos, por pesquisadores brasileiros e canadenses ${ }^{13}$, em articulação com comunidades ribeirinhas da região do médio rio Tapajós, Estado do Pará. O objetivo do projeto é caracterizar as fontes, as vias de transmissão e os efeitos do mercúrio sobre a saúde das populações locais (GUIMARÃES; MERGLER, 2011). Inclui, igualmente, a

\footnotetext{
${ }^{10}$ Trata-se da equinococose canina e humana, também conhecida como cisto hidático. Esta doença é causada pelo helminto da espécie Echinococcus granulosus, um tipo de tênia que vive no intestino principalmente de cães e seres humanos.

${ }_{11}$ A sociedade nepalense apresenta uma estratificação em castas, o que determina os locais de moradia e as profissões, bem como a disseminação da doença, os índices de morbidade e a expectativa de vida. A compreensão das interações entre os determinantes socioculturais, políticos, econômicos e ambientais foi imprescindível para reduzir a prevalência da doença na população (WEIHS; MERTENS, 2013).

${ }^{12}$ Financiada pelo Centro Internacional de Investigações para o Desenvolvimento (IDRC), do Canadá.

${ }_{13}$ Pesquisadores da Universidade Federal do Pará, Universidade Federal do Rio de Janeiro, Universidade de São Paulo (Ribeirão Preto), Universidade de Brasília, Universidade do Québec em Montréal, Universidade de Montréal e o Biodome de Montréal.
} 
participação das comunidades no desenvolvimento de estratégias para reduzir as fontes e a exposição ao mercúrio (MERTENS et al., 2005).

O projeto CARUSO proporcionou importantes descobertas. As investigações permitiram inferir que a concentração de mercúrio encontrado no organismo de peixes e cabelos de moradores locais não deriva somente dos garimpos de ouro, como se acreditava anteriormente. Na realidade, o próprio solo amazônico acumula quantidades significativas de mercúrio, associado à oxi-hidróxidos de ferro. A prática agrícola de corte-e-queima, tradicionalmente usada nessa região, geralmente aumenta a erosão do solo e a lixiviação de componentes químicos para os sistemas aquáticos. Estima-se que a queima de biomassa florestal libere cerca de 90 toneladas de mercúrio por ano para a atmosfera, sendo esta a principal fonte de mercúrio atmosférico na Amazônia, com significativa participação na contaminação dos ecossistemas aquáticos (GUIMARÃES, 2001; ROULET et al., 1999).

A iniciativa investiga não somente a origem do mercúrio, mas, também, os hábitos alimentares da comunidade e suas práticas agrícolas (MERTENS; SAINT-CHARLES; MERGLER, 2012). Com a participação de agricultores, professores, agentes de saúde e autoridades locais, pôs-se em prática uma campanha baseada no lema "Comer mais peixes que não comem outros peixes" e embasada por uma cartilha nominada "Degradação ambiental, mercúrio e saúde no Tapajós" (PROJETO CARUSO, 2008). A equipe do projeto reconhece atualmente as importantes transformações socioambientais ocorridas nas comunidades (MERTENS et al., 2005), sobretudo no que se refere à reorientação das práticas agrícolas e do consumo de peixe (FILLION et al., 2011). Segundo Lebel (2003), os resultados são notáveis, entre 1995 e 2002, a concentração de mercúrio no organismo dos moradores locais diminuiu em $40 \%$.

\subsubsection{Algumas perspectivas teóricas da Ecossaúde}

Para Lebel (2003), a abordagem da ecossaúde se fundamenta na visão antropocêntrica $^{14}$. Isto significa que, embora se origine das ciências ecológicas e evolutivas o que sugere a construção de uma concepção organicista, que considera o ser humano apenas como um pequeno elemento do mundo, e não o centro dele (VESTENA, 2011) -, a ecossaúde sustenta a compreensão de que equilíbrio entre a saúde coletiva e o meio ambiente depende da ação humana. Segundo o autor, o aspecto original da ecossaúde é que ela considera que as populações têm o poder de controle sobre o uso de seu ambiente, de forma destruidora ou, ao contrário, sustentável (LEBEL, 2003). Em síntese, a ecossaúde

\footnotetext{
${ }^{14} \mathrm{Na}$ visão antropocêntrica, a natureza existe para servir ao homem, ela está ao livre dispor da ação humana para exploração dos recursos naturais, bem como para a gestão sustentável de seu uso.
} 
permite que se explore as relações que existem entre os diferentes elementos de um ecossistema a fim de definir e avaliar os principais condicionantes da saúde humana e da sustentabilidade de seu ecossistema (FORGET; LEBEL, 2001).

Além disso, a abordagem da ecossaúde considera a relação meio ambiente e saúde a partir da noção de "sistema socioecológico complexo" ${ }^{15}$, uma abordagem que se coloca entre a teoria geral dos sistemas e o pensamento complexo.

\subsubsection{Contribuições da noção de "sistema socioecológico complexo"}

A noção de "sistema socioecológico complexo" ajuda a melhor compreender o arcabouço teórico que sustenta a abordagem da ecossaúde. Nesta perspectiva, considerase que os ecossistemas evoluem com o tempo, com alguns intervalos de estabilidade (NIELSEN, 2001). Nessa linha de raciocínio, entende-se que, ao longo do tempo, os componentes social e ambiental de um ecossistema se interconectam num movimento evolutivo, formando círculos que se retroalimentam (OPAS, 2009). A saúde do ecossistema depende, neste sentido, da saúde humana, assim como a saúde humana depende da saúde do ecossistema, sendo um, o atributo do outro. Se um deles falha, o todo perde o equilíbrio e se estabelece uma crise. Esse momento de tensão pode resultar na emergência espontânea de novas estruturas e formas de organização ou, ao contrário, num impacto irreversível (KAY et al., 1999; WALTNER-TOEWS, 2001; WALTNER-TOEWS et al., 2004).

Outro exemplo desta teoria é oferecido pelos atuais estudos sobre as mudanças climáticas. Entende-se, neste sentido, que a ação humana, principalmente por meio de mecanismos agroindustriais, teria aumentado a concentração de carbono na atmosfera, provocando desequilíbrios físico-químicos (estabelecimento da crise). As mudanças provocadas por estes desequilíbrios estariam, agora, afetando a própria dinâmica do desenvolvimento econômico, demandando a criação de alternativas para o desequilíbrio sociedade-ambiente. Emergiria, da implantação destas alternativas, uma nova fase de equilíbrio (coadaptação) ou, ao contrário, o colapso total do sistema (destruição).

Ao sair de uma crise, o sistema pode voltar às características anteriores ou adaptar-se para atingir uma nova fase de organização e complexidade (NICOLIS; PRIGOGINE, 1977, 1989). A existência de múltiplos estados estáveis, múltiplas possibilidades, implica, necessariamente, a "indeterminação", ou seja, a imprevisibilidade, natural de sistemas complexos (WALTNER-TOEWS et al., 2004).

\footnotetext{
${ }^{15}$ Os sistemas socioecológicos contemplam a inter-relação entre os sistemas humanos e os sistemas naturais, entendendo que a delimitação entre eles é artificial e arbitrária. Entende-se que nesses sistemas as regras simples de causa e efeito não se aplicam, pois eles são complexos, imprevisíveis e sofrem constante adaptação (STOCKHOLM RESILIENCE CENTRE, 2014).
} 
Estas teorias dão originalidade à abordagem da ecossaúde, sobretudo no que diz respeito à noção de indeterminação. Esta é uma das principais diferenças entre a ecossaúde e as abordagens tradicionais das ciências sociais, nas quais a saúde é abordada como o resultado de uma probabilidade de ocorrer um determinado evento (uma abordagem que raramente inclui amplos fatores externos). Ao incluir a ideia de indeterminação, incorpora-se a incerteza aos elementos de análise, ou seja, admite-se que nem todos os determinantes da relação ambiente-saúde podem ser conhecidos e que as abordagens são modelos ou abstrações da realidade, selecionadas ou definidas para servir para uma aproximação irregular do mundo (NIELSEN, 2001).

\subsubsection{A teoria dos sistemas e a abordagem da ecossaúde}

A mobilização da Teoria dos Sistemas oferece a vantagem de colocar a noção de sistema no centro da abordagem científica. Assim, ela permite analisar um conjunto de realidades não somente a partir da soma das partes, mas como um todo, em que as partes se interconectam e dialogam entre si. Além disso, ela oferece outras duas vantagens: (i) colocar a noção de sistema como uma teoria da realidade e (ii) situar-se no nível interdisciplinar, que permite articular as disciplinas científicas, sem uniformiza-las, mantendo sua diferenciação.

No que concerne à abordagem da ecossaúde, o enfoque sistêmico contribui para a articulação de diferentes disciplinas científica e a incorporação dos saberes e opiniões das pessoas que vivenciam o cotidiano dos problemas investigados. Estes princípios ganham materialidade, segundo Lebel (2003), a partir da transdisciplinaridade e da participação.

$\mathrm{Na}$ pesquisa transdisciplinar se trabalha pela articulação entre diferentes disciplinas científicas (interdisciplinaridade ${ }^{16}$ ) e os saberes informais (LEBEL, 2003). O objetivo é criar conexões entre a pesquisa acadêmica e a esfera das outras formas de saber, articulando o ponto de vista das pessoas e grupos sociais (HORLICK-JONES; SIME, 2004; STOKOLS et al., 2003). Parte-se do princípio, neste caso, que a teoria científica, embora tenha significativa importância para compreender um sistema de realidades, é limitada. Assim, para ter uma melhor visão do conjunto é preciso articular a ciência a outras formas de linguagem e estruturas do pensamento.

\footnotetext{
${ }^{16}$ A pesquisa interdisciplinar é realizada entre profissionais da ciência - pesquisadores, estagiários, estudantes - de diferentes áreas do conhecimento. O objetivo é, desde a primeira etapa da pesquisa, criar momentos de troca e cooperação entre pesquisadores, de forma que se consiga estabelecer um diálogo entre os corpos teóricos das diferentes disciplinas (LEBEL, 2003; LEFF, 2001).
} 
Neste contexto, o processo de pesquisa se desenvolve a partir de um contínuo processo de participação social, colocado em prática desde a fase de diagnóstico dos problemas, até a implantação de medidas de controle ou de minimização dos problemas abordados. Interessa abordar o sistema socioecológico a partir de uma perspectiva múltipla, valorizando a diversidade de atores e o amplo processo de discussão como meio de elaborar um panorama mais completo das perspectivas reais (WALTNER-TOEWS; FERNANDES; BRICEÑO-LEÓN, 2002).

\subsubsection{A operacionalização da pesquisa na abordagem da ecossaúde}

Freitas e colaboradores (2007) distinguem duas correntes de pesquisa centrada na abordagem da ecossaúde. A primeira corrente se dedica à construção de indicadores direcionados para a tomada de decisão e a gestão do ecossistema (FREITAS et al., 2007; RAPPORT, 1998). Os projetos debruçam-se sobre o mapeamento da estrutura do ecossistema, a partir de sistemas de informação geográfica (SIG), e a modelagem de sua função. Entende-se que o emprego dos mapas ou da modelagem ajuda a desentranhar as complexas interconexões entre os elementos do sistema, compreender suas relações funcionais e concentrar-se nos aspectos chave do problema (NIELSEN, 2001).

A segunda corrente se baseia em abordagens históricas. O processo de pesquisa se fundamenta pela compreensão contextualizada do problema. O objetivo é alcançar a complexidade dos problemas a partir da instalação de uma dinâmica (i) dialógica, que aproxima o pesquisador do objeto, e (ii) reflexiva, que olha o processo de pesquisa como uma construção, um percurso que precisa ser avaliado e reconduzido, para corrigir erros e atender a novas demandas.

Dentre as técnicas desenvolvidas com o objetivo de dar apoio a este tipo de investigação, encontramos a AMESH (WALTNER-TOEWS et al., 2004). Trata-se de um conjunto de etapas e questões que ajudam a operacionalizar as pesquisas de campo, bem como as análises dos resultados. Devido à sua importância para a nossa pesquisa, investimos alguns parágrafos para detalhar as suas características e destacar aquelas que nos foram úteis.

Nesta técnica, as atividades de campo e de análise dos resultados são divididas em quatro grandes etapas. Nas duas primeiras fases da pesquisa é feita uma reconstrução histórica, a partir de um diagnóstico baseado no ponto de vista da comunidade sobre a problemática em questão. São coletadas as várias histórias, fotos, versões da realidade e narrativas da comunidade. Pesquisadores, moradores, gestores públicos e demais interessados trabalham juntos. Para tanto, são organizadas oficinas participativas, 
workshops ou reuniões regulares do grupo. O objetivo é criar um espaço de diálogo entre as partes e proporcionar o ambiente necessário para que os grupos interessados possam verdadeiramente participar da atividade de pesquisa (WALTNER-TOEWS et al., 2004, 2005). A atuação da equipe de trabalho e da comunidade se dá, portanto, de forma conjunta e dialógica (WALTNER-TOEWS, 2001).

$\mathrm{Na}$ terceira e quarta fases, as múltiplas narrativas e versões da realidade são agrupadas e analisadas, objetivando uma compreensão sistêmica da problemática. Essa síntese é construída a partir de modelos teóricos produzidos no âmbito da ecologia evolutiva, aos quais são incorporados teorias e métodos oriundos das ciências humanas (WALTNER-TOEWS et al., 2004). A análise permite identificar as variáveis endógenas e exógenas que afetam o meio ambiente e a saúde (OPAS, 2009). Na quinta fase, analisa-se como se dá a tradução desse processo em termos de aprendizagem e ação colaborativa (WALTNER-TOEWS et al., 2004).

A abordagem desta vertente é orientada pela aprendizagem colaborativa que resulta do processo de diálogo (FREITAS et al., 2007). O objetivo central é a promoção de mudanças ou avanços em termos de valores sociais, no âmbito do desejo das pessoas que vivem nas comunidades afetadas (MINAYO, 2006; RAPPORT, 1998).

A AMESH configura a base dos métodos empregados nesta pesquisa, os quais serão descritos na seção correspondente. Por ora, dentre as perspectivas mais importantes oferecidas por esta técnica para o estudo em questão, destacamos: (i) a pesquisa participativa, inclinada para a coleta dos pontos de vista da população sobre a relação entre a saúde e a degradação ambiental e (ii) a organização de diagramas nas etapas de análise dos resultados. O investimento no diálogo, durante as fases de coleta das informações, é outro elemento extraído desta técnica, que fundamenta o método adotado no estudo.

\section{Conclusão}

Este capítulo apresentou alguns dos elementos teóricos e metodológicos que sustentam a pesquisa. Notamos que saúde e meio ambiente, além de fronteira agrícola abordada no próximo capítulo - estão entre as noções teóricas de maior importância para a o estudo. Elas são sustentadas principalmente pelas áreas da saúde coletiva e das ciências ambientais. Contudo, ao longo do texto fomos percebendo que esta demarcação entre as disciplinas não é evidente. Isto ocorre principalmente porque se trata de uma pesquisa de caráter interdisciplinar, marcada pela articulação do conhecimento das diferentes disciplinas. Em linhas gerais, tal articulação é promovida pela área da saúde ambiental. 
Sob o ponto de vista conceitual, adotamos a noção de meio ambiente na perspectiva da construção social, ou seja, no contexto deste estudo, o meio ambiente é tratado como o resultado, observado nos ecossistemas, do desenvolvimento tecnológico e industrial. $\mathrm{O}$ processo saúde-doença, por sua vez, é interpretado a partir da interconexão entre o risco e as transformações do meio ambiente. Vale ressaltar que o risco é um fenômeno construído socialmente pelos grupos expostos às ameaças geradas pelo meio ambiente.

No que se refere aos aspectos metodológicos, destacamos o potencial que encontramos na ecossaúde e na técnica denominada AMESH. Ambas foram importantes porque ofereceram as bases para o desenvolvimento de uma abordagem participativa e interdisciplinar. Ademias, as etapas de campo delineadas pela AMESH contribuíram, de forma definitiva, para o desenho da pesquisa e para a organização e análise dos resultados. 


\section{Capítulo 2. CICLO DE VIDA DA FRONTEIRA: QUE RELAÇÃO COM O MEIO AMBIENTE?}

\section{Introdução}

No capítulo anterior, fizemos uma revisão da constituição dos estudos da relação entre a degradação ambiental e a saúde humana. A distinção entre a abordagem teórica, que se encontra na área da saúde ambiental, e o enfoque metodológico, definido pela ecossaúde, foi fundamental para compreendermos como esses temas são investigados atualmente. Neste capítulo, trazemos uma segunda perspectiva, que nos ajuda a compreender o objeto aqui abordado: a interface meio ambiente e saúde em uma fronteira agrícola. Trata-se de um esforço para caracterizar a fronteira agrícola a partir de um constructo teórico fundamentado pela Teoria dos Sistemas. Neste contexto, é escolhida a área da geografia para subsidiar a descrição da constituição e evolução da fronteira, as formas de uso e ocupação do espaço e as respectivas consequências aos ecossistemas.

Para compreender a dinâmica assumida pelas fronteiras sob a ótica do meio ambiente, orientamos nossa abordagem pela noção de "ciclo de vida" (ALBALADEJO et al., 1996; ALBALADEJO; ARNAULD DE SARTRE, 2005; COY, 1996). Trata-se de um enfoque que ajuda a compreender os modos de emergência das fronteiras, sua evolução e as diferentes formas de integração aos contextos nacional e internacional. No cerne da abordagem está a distinção entre a produção da problemática ambiental, durante a primeira fase de ocupação da fronteira, e o esforço de adaptação às novas demandas criadas pelo movimento ambientalista, as agendas de governo e o mundo dos negócios, na fase atual.

Esta problematização da fronteira, a partir da ótica ambiental, objetiva fornecer as bases para compreender a relação entre a degradação ambiental e os grandes problemas de saúde ambiental, que são descritos no capítulo subsequente.

\subsection{A noção de fronteira}

A teoria da fronteira agrícola que conhecemos foi forjada originalmente pelo norteamericano Frederick Jackson Turner, na publicação do artigo "The significance of the frontier in American history" (1910). Segundo Franco e colaboradores (2012, p. 12), na noção de Turner, a fronteira agrícola é entendida, "não como border, limite geográfico entre países ou territórios políticos, mas como frontier, terra livre - ou considerada livre - em processo de ocupação ou colonização". 
Em francês, o termo é traduzido como front pionnier (frente pioneira). Trata-se de um território em processo de anexação econômica ao espaço nacional, que tem os recursos naturais e a agropecuária, como carro-chefe da economia. No caso da Amazônia brasileira, esse processo é marcado por alguns fatores específicos, tais como: uma brutal transformação do meio natural, uma descontinuidade econômica ${ }^{17}$, uma estigmatização ambiental e uma importante capacidade de gerar novas realidades (BECKER, 1988; POCCARD-CHAPUIS, 2004).

Segundo Becker (1988, p. 67), a fronteira agrícola contém os "elementos essenciais do modo de produção dominante e da formação econômica e social em que se situa". Ela representa, portanto, os interesses do capital industrial e financeiro e reproduz, em grande parte, os problemas nacionais: desigualdade social, pobreza, concentração fundiária, urbanização desenfreada, industrialização deficiente, contaminação ambiental, entre outros. Contudo, a fronteira se distingue do espaço nacional pela velocidade que ganham estas mudanças.

Outro fator de destaque é a dimensão ambiental. Na fronteira se produz uma ampla devastação do ecossistema amazônico, notadamente a partir de desmatamento, queimadas, perda da diversidade biológica e de terras cultiváveis.

Paradoxalmente, a fronteira também se define pela capacidade de adaptar-se à pressão ambientalista e governamental, em termos de reorientação da matriz de desenvolvimento. Essa pressão deriva da ampliação da consciência ecológica mundial, colocada em curso a partir da década de 1960. Na fronteira, ela gera uma série de mudanças que direcionam a lógica do desenvolvimento para uma base mais sustentável (BECKER, 2009).

Ainda no intuito de melhor compreender o que representa a fronteira, vale ressaltar que, "a fronteira não é um objeto empírico real, uma região ou ainda uma fase na vida de uma região, mas, sim, uma forma de propor uma investigação" (OLIVEIRA FILHO, 1979, p. 111). A noção de fronteira serve, nesta perspectiva, apenas à aplicação de uma análise. Ela ajuda a aumentar o rendimento do ponto de vista da aplicação do conhecimento. As pessoas que habitam nessas regiões pouco conhecem ou desconhecem, por completo, tal designação.

Existem diversas abordagens, usadas para empreender este tipo de estudo. Elas se sustentam em disciplinas sociais, geográficas, agrárias, entre outras. No entanto, tendo em vista a complexidade teórica gerada pela questão ambiental, descrita no capítulo anterior, algumas abordagens recentes vem ultrapassando os limites dessas disciplinas. $\mathrm{Na}$

\footnotetext{
${ }^{17}$ Traduzida em diversos ciclos: agricultura, pecuária, madeira, garimpo, principalmente.
} 
perspectiva mais abrangente, a fronteira é analisada como um sistema em evolução. Esta visão inclui uma ideia positiva do futuro, ao considerar a capacidade de adaptação da fronteira às mudanças provocadas pela questão ambiental.

Opta-se, neste trabalho, por analisar a fronteira com base na noção de "ciclo de vida", construída, principalmente, por Coy (1996) e Albaladejo e colaboradores (1996) e amplamente comentada por Albaladejo e Arnauld de Sartre (2005). Nesta perspectiva, a fronteira é compreendida como uma sucessão de fases que se interconectam no tempo. São elas: (i) fronteira potencial, fase de planejamento; (ii) ocupação, as primeiras formas de organização espacial; (iii) diferenciação interna (consolidação), marcada por um encadeamento de diferentes modalidades de ocupação e uso do espaço (agricultura familiar, garimpo, madeira, pecuária, soja, etc.) e (iv) integração definitiva ao espaço nacional/internacional, em termos econômicos e ambientais.

De forma específica, o que nos interessa ao adotar toda essa moldura conceitual é a possibilidade de visualizar o avanço da ocupação da fronteira em paralelo à evolução da problemática ambiental.

\subsection{A fronteira vista como um sistema em evolução: considerações preliminares}

Para analisar um sistema de realidades, complexo e dinâmico e em permanente transformação, como a fronteira, é importante refletir sobre a abordagem teórica que se deseja adotar. Essa preocupação se torna ainda mais pertinente quando consideramos que o contexto em que a fronteira emerge e evolui, na Amazônia, é aquele no qual também emerge e evolui, no circuito nacional ${ }^{18}$ e internacional, a questão ambiental. Ou seja, para bem compreender nosso objeto de estudo, precisamos definir um quadro teórico que permita a convergência da abordagem da fronteira com a ambiental.

Acreditamos que a ciências dos sistemas nos ajudam nesse sentido. Nesta perspectiva, acredita-se que o social, o natural e o cultural, entre outros fatores, não menos importantes, formam um todo hierarquizado, que se traduz na realidade que conhecemos. $A$ posição que cada um dos fatores ocupa nessa hierarquia, pode variar no decorrer do tempo (como acontece, por exemplo, na fronteira, em relação à posição do meio ambiente nas decisões políticas). Entretanto, mesmo havendo maior peso de um fator sobre o outro, o resultado final é sempre dado pela interação entre os múltiplos fatores. No limite, esse

\footnotetext{
${ }^{18}$ É importante lembrar que o movimento socioambientalista organizado por Chico Mendes, no Acre, a partir da década de 1970, teve importante influência na construção da questão ambiental no Brasil.
} 
resultado pode ser o colapso do próprio sistema ou, ao contrário, a produção de novas formas de organização, mais resilientes (PÁDUA, 2010).

Esta abordagem também permite que se conceba que, num sistema, as condições anteriores não refletem, necessariamente, as condições atuais ou futuras, uma vez que o sistema pode se transformar ao longo do processo. No caso da Amazônia, por exemplo, ao tempo em que a expansão da fronteira provoca danos ambientais irremediáveis, produzindo uma ideia de "fim da Amazônia", as novas imagens da natureza lançadas pelo mito do "pulmão do mundo", entre outros aspectos, contribuem com mudanças na dinâmica do desenvolvimento. Nesta perspectiva, ao invés de um "colapso" no sistema, cenário previsto por vários teóricos (CELENTANO; VERÍSSIMO, 2007; COY, 1996; SCHNEIDER et al., 2000), o que se observa na fronteira é uma gradativa adaptação à questão ambiental (ALBALADEJO et al., 1996; BECKER, 2009).

\subsubsection{A teoria do ciclo de vida da fronteira}

Como estudar a fronteira a partir da ciência dos sistemas? Coy (1996) e Albaladejo e colaboradores (1996) o fazem a partir de três fases: perturbação, flutuação e estabilização (figura 1). Para explicar a evolução destas fases, os autores se reportam à "teoria da equilibração" de Jean Piaget. Neste sentido, se aceita que a tendência do sistema é o equilíbrio. Como uma criança, durante o seu desenvolvimento mental, a fronteira desenvolveria, ao longo do tempo, uma "inteligência". Ela seria formada, de uma parte, a partir da assimilação de informações e interpretação do novo ambiente e, de outra parte, pela acomodação, ou seja, a adaptação a esse ambiente.

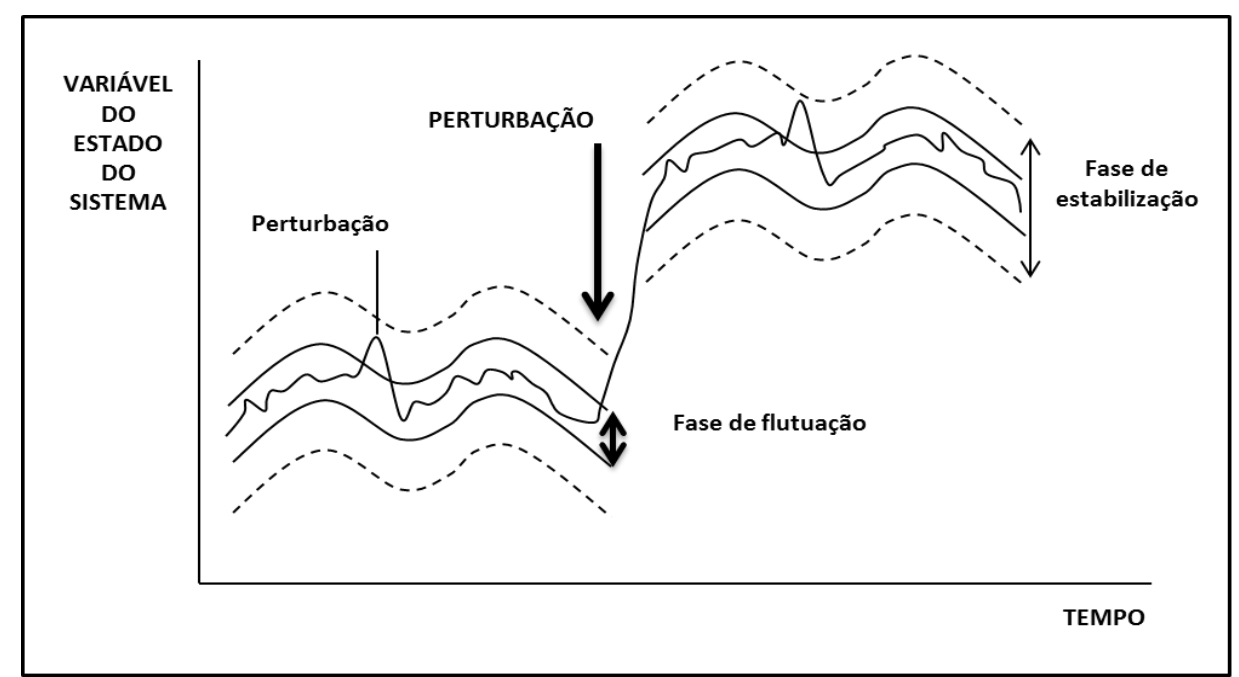

Figura 1 - Representação esquemática das fases da evolução da fronteira agrícola. Fonte: Albaladejo e colaboradores (1996). 
Nessa interpretação, concebe-se que desde a ocupação do novo espaço (fase de perturbação), os atores vêm construindo conhecimento sobre o novo ambiente (não sem resistências a ele). $\mathrm{O}$ acumulado de conhecimento teria permitido que os atores se modificassem, a fim de melhor se adaptar a esse meio, e, paralelamente, modificassem o meio a seu favor (fase de flutuação) (PÁDUA, 2009; PIAGET, 1976). O resultado seria um sistema que aprendeu com as diferentes etapas de seu desenvolvimento e, por isso, estaria potencialmente preparado para enfrentar as dinâmicas emergentes (fase de estabilização) (ALBALADEJO et al., 1996).

Nesta perspectiva, acredita-se que a fronteira que existe hoje, não é mais uma região distinta, ou em decadência, como se aceitava até pouco tempo. "Mas sim uma área de povoado consolidado, com significativo potencial de desenvolvimento, seja pela intensificação do povoamento e das atividades produtivas, seja pela recuperação das áreas alteradas e/ou abandonadas" (BECKER, 2009, p. 76).

\subsubsection{O ciclo de vida e as transformações do meio ambiente}

Buscando aproximar o quadro teórico apresentado anteriormente e os eventos históricos que marcam o desenvolvimento da fronteira, tratamos, a partir daqui, das fases do ciclo de vida da fronteira. Nosso intuito é melhor compreender quais foram - e são - as dinâmicas que produzem a degradação do meio ambiente. A figura 2 oferece os elementos para a descrição que segue.

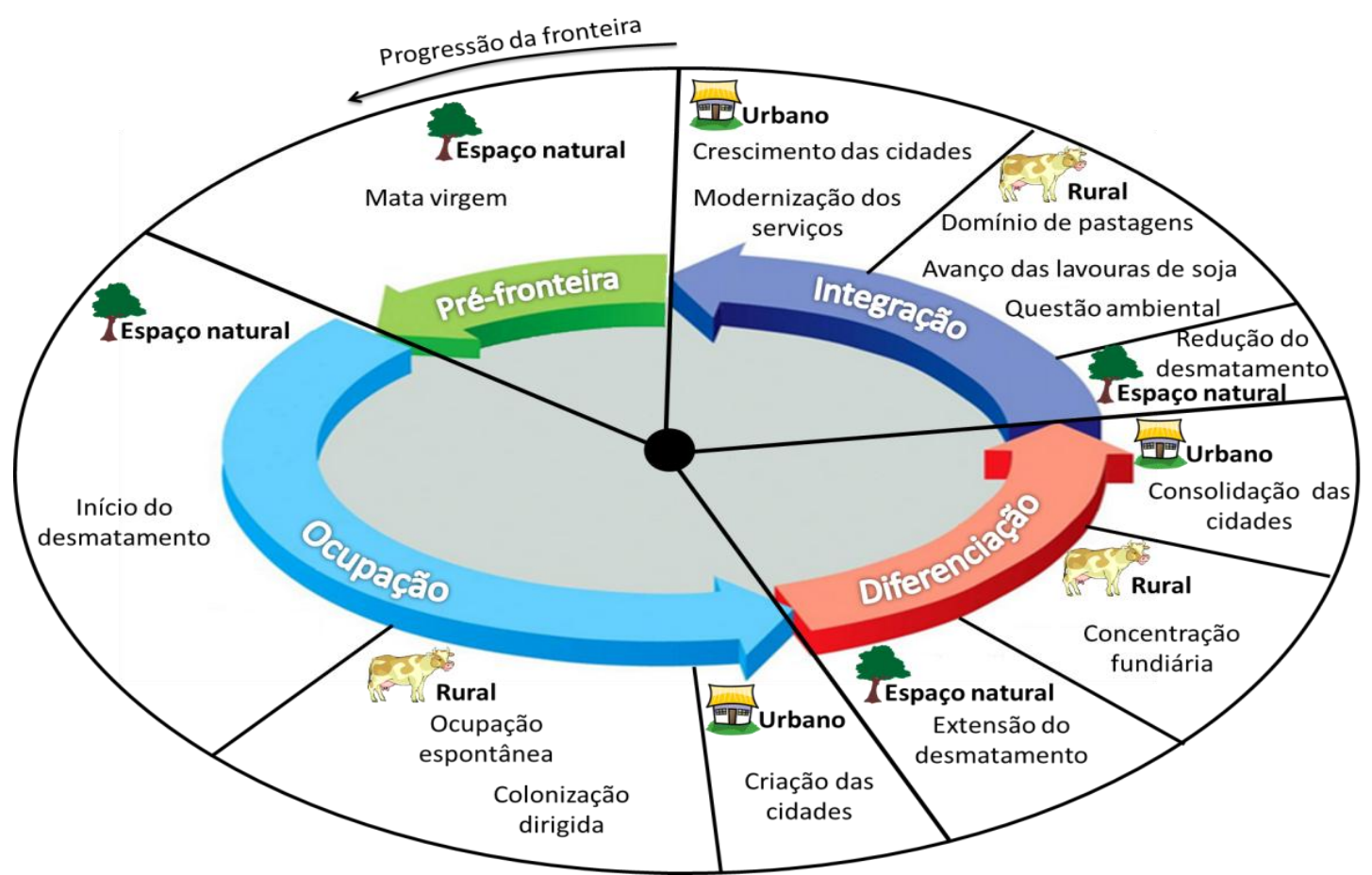

Figura 2 - Ciclo de vida da fronteira. Autoria própria. Produzido a partir das reflexões de Arnauld de Sartre (2006), Albaladejo e colaboradores (1996) e Becker (2009). 


\subsubsection{Pré-fronteira: espaço virgem}

A pré-fronteira, ou fronteira potencial, como é originalmente designada por Albaladejo e colaboradores (1996), se refere à fase de concepção dos programas e projetos de colonização do território. Nesta etapa, o espaço é considerado "virgem" em termos de atividade produtiva estável (REBORATTI, 1979). A vegetação natural ocupa mais de $90 \%$ do território (ARVOR, 2009). A ocupação social pode ser imaginada por diversos atores, mas sua concepção é, geralmente, produzida pelo Estado (ALBALADEJO et al., 1996).

A pré-fronteira é uma fase importante para o futuro do espaço a ser ocupado: é quando são feitos os acordos que definem as concessões, público ou privadas, e são aprovados os "projetos de colonização". Tais processos têm consequências importantes para o futuro da fronteira e a vida da população local (ALBALADEJO et al., 1996).

$\mathrm{Na}$ Amazônia, o espaço ainda é de domínio de populações indígenas, camponeses posseiros ou grileiros ou serve a outros tipos de ocupação, tênues, geralmente relacionados à atividade de defesa nacional ou de construção de obras de infraestrutura (ALBALADEJO et al., 1996; MARTINS, 1997; REBORATTI, 1979). Tal ocupação promove algum tipo de desmatamento, mas, de forma geral, predominam práticas que combinam a utilização econômica com o manejo dos recursos naturais (BENTES, 2005). Em linhas gerais, os impactos ambientais só ganham relevância com o início de sua ocupação agrícola.

\subsubsection{A ocupação agrícola}

Esta fase inaugura a efetiva ocupação permanente e o começo de uma organização espacial (cidades, serviços, estradas, etc.) (ALBALADEJO et al., 1996). Trata-se de uma etapa que é examinada pelos estudiosos do tema, ou como "frente de expansão", ou, distintamente, como "frente pioneira". Martins (1996) nos ajuda a diferenciá-las. A frente de expansão, segundo o autor, é usada, principalmente por antropólogos, como sinônimo de "fronteira da civilização". Segundo o autor, "ela expressa a concepção de ocupação do espaço de quem tem como referência as populações indígenas" (MARTINS, 1996, p. 28).

Neste caso, aborda-se o impacto da expansão "branca" sobre essas populações (MARTINS, 1996). No Norte de Mato Grosso, ela atingiu os povos Munduruku, Apiaka, Kaiabi, Rikbaktsa e Kreen-Akarore, que originalmente ocuparam esse espaço ${ }^{19}$, provocando

\footnotetext{
${ }^{19}$ As investidas mais recentes, neste sentido, foram de trabalhadores da indústria da borracha, no final do século XIX e início do século XX, de equipes da construção de linhas telegráficas, chefiadas por Marechal Rondon, de trabalhadores da construção da BR-163 e, nas últimas décadas, de agricultores, envolvidos com os projetos de colonização agrícola. O tamanho dessas populações foi potencialmente reduzido a partir do contato com o colonizador. Os principais impactos foram causados por doenças infecciosas e confrontos armados. O deslocamento geográfico dos
} 
epidemias e executando massacres. Segundo Martins (1996), essa negligência dos povos nativos fez parte da própria concepção dos projetos de colonização. Durante a fase de ocupação, eram comuns os ataques organizados aos indígenas, executamos principalmente por grandes proprietários de terra. Ademais, não só eles foram envolvidos nas lutas pela terra, também os camponeses pobres, antigos ocupantes, sem título legal da terra, foram alcançados pela violência, assassinatos, expulsões e destruição de casas e povoados (MARTINS, 1996, 1997).

Em linhas gerais, o lado dos indígenas, no processo de ocupação da fronteira, desperta pouco interesse aos estudiosos da "frente pioneira". Para estes pesquisadores a fronteira existe a partir da figura do pioneiro (MONDARDO; GOETTERT, 2007). Neste caso, a ênfase das análises está nas formas de uso e ocupação do espaço, adotadas pelos agentes do deslocamento de atividades agropecuárias. Uma abordagem que é atribuída aos geógrafos (MARTINS, 1997).

A "frente pioneira" configura a fase de migração e instalação de famílias de agricultores, bem como a chegada do empreendimento econômico (empresas colonizadoras, comerciais, bancárias, etc.), da infraestrutura (estradas, cidades, criação das fazendas, etc.) e dos serviços essenciais como a saúde (BECKER, 1990; LE BORGNEDAVID, 1998). Trata-se do início do processo de incorporação da fronteira aos circuitos econômicos modernos, nacionais e internacionais (DROULERS; LE TOURNEAU, 2000).

\subsubsection{3. $\mathrm{O}$ avanço da fronteira agrícola, a degradação e a questão ambiental}

Segundo Sawyer (1984), a ocupação agrícola da Amazônia baseou-se em um duplo objetivo: atender ao excedente populacional produzido pela modernização da agricultura, principalmente nos Estados do Nordeste e do Sul, e ao mercado, via produção de alimentos e matérias-primas ${ }^{20}$. Esses mecanismos geraram um intenso movimento de apropriação de terras e de recursos naturais, viabilizado e subsidiado pelo Estado e colocado em prática por diversos atores, muitas vezes, para criar condições de manutenção e sobrevivência no novo espaço (ALBALADEJO et al., 1996; BECKER, 1988).

Os interesses e a percepção dominantes daquela época atribuíam à região amazônica a condição de fronteira de recursos, ou seja, área de expansão da economia (BECKER, 2009). A ideia compartilhada entre as famílias de agricultores que ali se estabeleceram - e

sobreviventes, sobretudo para o Parque Indígena do Xingu, foi promovido pelas equipes da construção da BR-163, no início dos anos 1970 (MARTINS, 1996; TEMPESTA, 2009, 2010a, 2010b).

${ }^{20}$ Esse processo de ocupação foi orientado pela doutrina do regime militar (1964-1984): "Terras sem homens para homens sem terra". A Amazônia representava, nestes termos, uma nova reserva de espaço. O lema que orientava a política governamental era: "Integrar para não entregar", isto é, manter o domínio do território. 
propagandeada pelo governo militar -, era a da "terra da riqueza" (GUIMARÃES NETO, 2002). A dominação da natureza era vista como uma solução para o desenvolvimento do país (GONÇALVES, 2004).

No início, a floresta foi vista como uma natureza selvagem passível de domesticação. Os produtores rurais se punham a abrir as áreas florestais em tempos recordes, a fim de formar as primeiras áreas de pastagens, iniciar o cultivo de espécies perenes (café, guaraná, cacau, etc.) ou culturas anuais, como o arroz (COY, 1996). Na maioria dos casos, quase nada da madeira era aproveitada, exceto para a construção local (TOURRAND; VALARIÉ; OLIVEIRA, 2007). A luta dos agricultores pela sobrevivência ou pela conquista da autonomia do trabalho familiar na agricultura, embora não justifique, explica, em boa medida, essa dinâmica implantada na fronteira (ALBALADEJO et al., 1996; ARNAULD DE SARTRE, 2006; LE BORGNE-DAVID, 1998).

Um dos fenômenos dinamizadores da degradação do meio ambiente nas fronteiras foi o uso do fogo. Desde o início da ocupação, o fogo foi usado para eliminar restos de floresta derrubada, livrar as pastagens de ervas invasoras ou, mesmo, renovar as áreas de pastagem (NEPSTAD; MOREIRA; ALENCAR, 1999). De forma geral, a formação das novas propriedades agrícolas ocorria mediante a completa derrubada das árvores, realizada com o auxílio de uma corrente de navio, presa a dois tratores esteiras. Em outros casos, foram aplicados herbicidas, com uso de aviões, sobretudo na formação de grandes fazendas (LESSA, 1991).

O uso do fogo também faz parte de uma prática tradicional da Amazônia, de preparo do solo para plantio, conhecida como corte-e-queima. Neste sistema, a queima é feita entre dois períodos de cultivo, após o corte da vegetação secundária (capoeira). Ela tem como objetivo disponibilizar a cinza ao solo, a qual cumpre a função de fertilizante e corretora de acidez (ABREU SÁ et al., 2006).

Em relação à limpeza de pastagens, o fogo foi usado para eliminar parte do capim rejeitado pelo gado, bem como, algumas plantas tóxicas. O maior problema é que essas queimadas dificilmente ficaram restritas às áreas de pastagem. Muitas vezes, o fogo escapou do controle, invadiu florestas primárias ou previamente exploradas por madeireiras, e disseminou-se por grandes áreas florestais.

Além dos incêndios florestais, a expansão dos garimpos de ouro também contribuiu para degradar o meio ambiente. Entre 1985 e 1991, a Amazônia recebeu uma multidão de garimpeiros, movida pelo disparo do preço do ouro no mercado internacional. Mais 2.000 áreas de garimpo foram abertas (LACERDA, 1997). Esta "corrida do ouro" não só ameaçou a efetividade dos projetos de colonização, devido à migração de agricultores para a atividade garimpeira (JOANONI NETO, 2007), como teve importantes implicações 
ambientais. A degradação deixada pela exploração mineral inclui a desestruturação do solo, pela eliminação da camada orgânica, alteração física de cursos d'água e a sua contaminação por mercúrio (CAHETÉ, 1998; WASSERMAN; HACON; WASSERMAN, 2001).

Entretanto, como afirma Piketty e colaboradores (2005a), a principal causa da derrubada e eliminação da vegetação nativa foi, sem margem de dúvida, a expansão da pecuária extensiva (corte e leite). Segundo a autora, e sua equipe, essa prática ocupa atualmente cerca de $80 \%$ das áreas desmatadas nas fronteiras. Completam o quadro, a exploração madeireira e o avanço da produção de commodities ${ }^{21}$ agrícolas, como a soja, o algodão e o milho. Essa produção se perpetua, sobretudo, na porção Sul e Leste da Amazônia (Rondônia, Mato Grosso, Tocantins, Maranhão e Pará).

Existem diversos outros fatores considerados como dinamizadores da degradação no território amazônico. Dentre eles, podemos citar:

- A valorização das propriedades depois de abertas e, em certos casos, o aceleramento do processo de obtenção do título da terra (DROULERS; LE TOURNEAU, 2000).

- A relativa institucionalização coletiva do desmatamento, uma vez que a efetividade do Estado em termos de aplicação da legislação ambiental era quase nula, frente ao volume de incentivos para a abertura das áreas florestais (MUELLER, 1992).

- O empobrecimento do solo, que provocou o abandono de áreas e impeliu agricultores a continuar avançando em direção à mata (DROULERS; LE TOURNEAU, 2000).

- Os investimentos na abertura e pavimentação de estradas, uma vez que eles aumentam a viabilidade econômica da agropecuária e da exploração de madeira (SOARES-FILHO et al., 2005).

- O viés adotado pela política agrícola brasileira, em prol de uma agricultura moderna e exportadora de alimentos (a lógica da Revolução Verde ${ }^{22}$ ) (BECKER, 2005a).

Em conjunto, esses elementos contribuíram para o quadro de desmatamento e degradação ambiental que hoje conhecemos. Segundo Fearnside (2005), a extensão

${ }^{21}$ Commodities são produtos agropecuários de fácil negociação no mercado global. Entre eles, podemos citar: carne bovina, soja, café, minerais - como ouro, prata, petróleo e platina - e produtos industriais, como tecidos, ferro gusa e açúcar. A comercialização ocorre por meio das bolsas de valores, em quais são definidos os preços das mercadorias no mercado internacional, obedecendo a fatores como de oferta e demanda.

${ }^{22}$ A modernização da agricultura teve suas bases na Revolução Verde, produzida no pós-Guerra. Esse modelo se disseminou pelos países menos desenvolvidos a partir das décadas de 1960/70. Ele se baseia na invenção e disseminação de novas sementes e práticas agrícolas, melhoramento genético de sementes, uso intensivo de insumos industriais, mecanização e redução do custo de manejo. O objetivo final é o aumento da produtividade. As suas consequências sociais e ambientais são bastante criticadas, sobretudo no que diz respeito à marginalização de trabalhadores e as ameaças a ecossistemas e à saúde das populações consumidores e daquelas que moram e trabalham nas proximidades das áreas de produção. 
cumulativa desse desmatamento chega a $16,2 \%$ dos $4 \times 106 \mathrm{~km}^{2}$ da floresta original da Amazônia Legal. Dados recentes do Instituto Nacional de Pesquisas Espaciais (INPE, 2014a), sugerem que o desmatamento possa ter atingido cerca de $20 \%$ da área de floresta $^{23}$. A dimensão dos danos ambientais é ainda maior quando se considera a degradação das áreas remanescentes, provocada, sobretudo, pelo corte seletivo, os incêndios (facilitados pelo corte seletivo) e os efeitos da fragmentação da vegetação e da formação de borda, isto é, das áreas de contato da floresta com a zona de plantio.

Do ponto de vista ambiental, os estragos produzidos por esse processo são considerados irreparáveis. O desmatamento provocou uma vasta destruição de ecossistemas, com importante perda de espécies e da diversidade genética (DROULERS; LE TOURNEAU, 2007). O sistema de produção agropecuário produziu erosão, degradação de solos e está relacionado a incêndios que produzem a degradação de extensas áreas florestais (ARTAXO et al., 2005; LE BORGNE-DAVID, 1998). Além disso, o uso intensivo de agrotóxicos nos estados que se situam na porção Sul da Amazônia Legal ${ }^{24}$, onde nasce uma parte importante dos cursos d'água do sistema hidrográfico amazônico, ameaça a qualidade da água que flui para as regiões jusantes dos rios (DROULERS; LE TOURNEAU, 2007; WASSERMAN; HACON; WASSERMAN, 2001).

\subsubsection{Diferenciação, integração e a nova configuração ambiental}

O atual aumento da produtividade nas lavouras de grãos e a modernização da atividade pecuária, entre outros aspectos, consolidam a fronteira como produtora de alimentos. Ela perde a mobilidade no espaço e adquire uma dinâmica regional própria. Nas lavouras, observa-se a substituição da expansão horizontal pelo crescimento vertical/intensivo, um processo que poupa a abertura de novas áreas (BECKER, 2009).

No decorrer desse processo, também ocorre a adequação da fronteira à legislação ambiental (TOURRAND; VALARIÉ; OLIVEIRA, 2007). A partir da década de 1990, a pressão do movimento ambientalista internacional começa a pesar contra a política desenvolvimentista implantada pelos governos brasileiros na Amazônia (ALBALADEJO; ARNAULD DE SARTRE, 2005). Por um lado, a pressão de consumidores preocupados com a destruição da floresta cria dificuldades para a inserção dos produtos da Amazônia no

${ }^{23} \mathrm{O}$ total de desmatado acumulado na Amazônia Legal, em 2012, foi de $752.549 \mathrm{Km}^{2}$, o que representa $14.91 \%$ sobre a área total ou $18.85 \%$ sobre área de floresta (INPE, 2014a).

${ }^{24}$ Amazônia Legal é conceito político e não de um imperativo geográfico. O termo foi cunhado depois de 1948, a partir da criação da Superintendência do Plano de Valorização Econômica da Amazônia (SPVEA). A finalidade era circunscrever um território para facilitar o planejamento e ação coletiva em prol do desenvolvimento da agropecuária e a integração da Amazônia à economia nacional. Ela engloba nove Estados: Acre, Amapá, Amazonas, Pará, Rondônia, Roraima e Tocantins, Mato Grosso e Maranhão. 
mercado internacional, afetando, sobretudo, setores como da soja, dos biocombustíveis e da pecuária (ABRAMOVAY, 2010; NEPSTAD; ALMEIDA, 2005).

Por outro lado, o próprio Banco Mundial e outras instituições financeiras, que vinham financiando os grandes projetos de infraestrutura nas fronteiras, obrigam o governo brasileiro a adotar "uma política regional voltada para um novo padrão de desenvolvimento, sustentável" (BECKER, 2009, p. 28). Essa pressão influencia a criação de unidades de conservação, o aumento da efetividade nos instrumentos da política ambiental (BURSZTYN, 2004) e a implantação de projetos alternativos de desenvolvimento - produção agroecológica, orgânica, artesanato, extrativismo, economia solidária, etc. -, dentre outros (BECKER, 2005b, 2001, 2009).

Outras mudanças resultam da percepção do valor estratégico da natureza para o desenvolvimento. Neste sentido, o território amazônico é invadido por diversos projetos que têm como norte a "mercantilização da natureza". A biodiversidade ganha valor nas mãos da biotecnologia, biologia molecular e química de produtos naturais, as quais subsidiam o desenvolvimento de produtos industriais, de base natural e alto valor agregado (BECKER, 2001, 2009). Ademais, a produção agropecuária e, inclusive, algumas cidades amazônicas, passam a orientar-se por sistemas de certificação, gerando um processo de adaptação aos ditos "mercados verdes" (NEPSTAD; ALMEIDA, 2005).

A intensificação da fiscalização, sobretudo na gestão do governo de Luís Inácio Lula da Silva (2003-2010), reduz as taxas de desmatamento, o que também tem efeito sobre as queimadas (ABRAMOVAY, 2010). Segundo Nepstad e Almeida (2005), essa readaptação ambiental é uma resposta às pressões sobre os mercados locais, exercidas por instituições financeiras internacionais, bem como, por consumidores interessados na conservação da floresta.

Em termos gerais, podemos afirmar que pelo menos quatro fenômenos efetivam a adaptação da fronteira à nova configuração ambiental. São eles:

- A carne bovina produzida na Amazônia é taxada como agente de desmatamento. Supermercados e consumidores passam a recusa-la (HOMMA, 2012).

- O governo brasileiro intensifica a fiscalização ambiental, amplia a luta contra a criminalidade e a corrupção no setor meio ambiente. Em poucos anos, são colocadas em ação mais de dez operações policiais ${ }^{25}$, que prendem empresários e técnicos ambientais,

\footnotetext{
${ }^{25}$ Ao todo, 11 grandes operações policiais, dentre as quais, a Operação Curupira (2005/6) foi uma das mais importantes, atuaram no controle do desmatamento e na investigação de fraudes e casos de corrupção ambiental. Foram desmanteladas grandes quadrilhas que atuavam na extração e comercialização ilegais de madeira em vários Estados da Amazônia. Mato Grosso foi um dos Estados que mais se destacaram nesse processo (http://www.socioambiental.org, 2014).
} 
envolvidos com a ocupação ilegal de terras coletivas e a extração ilegal de madeira. Mato Grosso é o Estado mais investigado.

- O MMA publica uma lista dos municípios que mais desmatam na Amazônia, o que produz limitações comerciais. Para recuperar-se, os municípios precisam assumir metas de prevenção, monitoramento e controle do desmatamento ilegal. Cria-se, por consequência, em alguns municípios, uma dinâmica de "esverdeamento" local, da qual participam atores públicos, comerciantes e produtores rurais, em favor da redução das taxas de desmatamento. Em menos de cinco anos, municípios como Alta Floresta e Marcelândia, no Mato Grosso, e Tailândia e Novo Brasil, no Pará, são excluídos da referida lista.

Assim, do mesmo modo que políticas coletivas e a globalização macroeconômica negligenciam o desmatamento, na primeira fase de ocupação da Amazônia, impõem, na fase atual, a adaptação da fronteira a um modelo de desenvolvimento mais sustentável, principalmente sob o ponto de vista ambiental. As expressivas quedas nas taxas de desmatamento (gráfico 1), observadas nos últimos anos confirmam essa mudança (BRANDO et al., 2013).

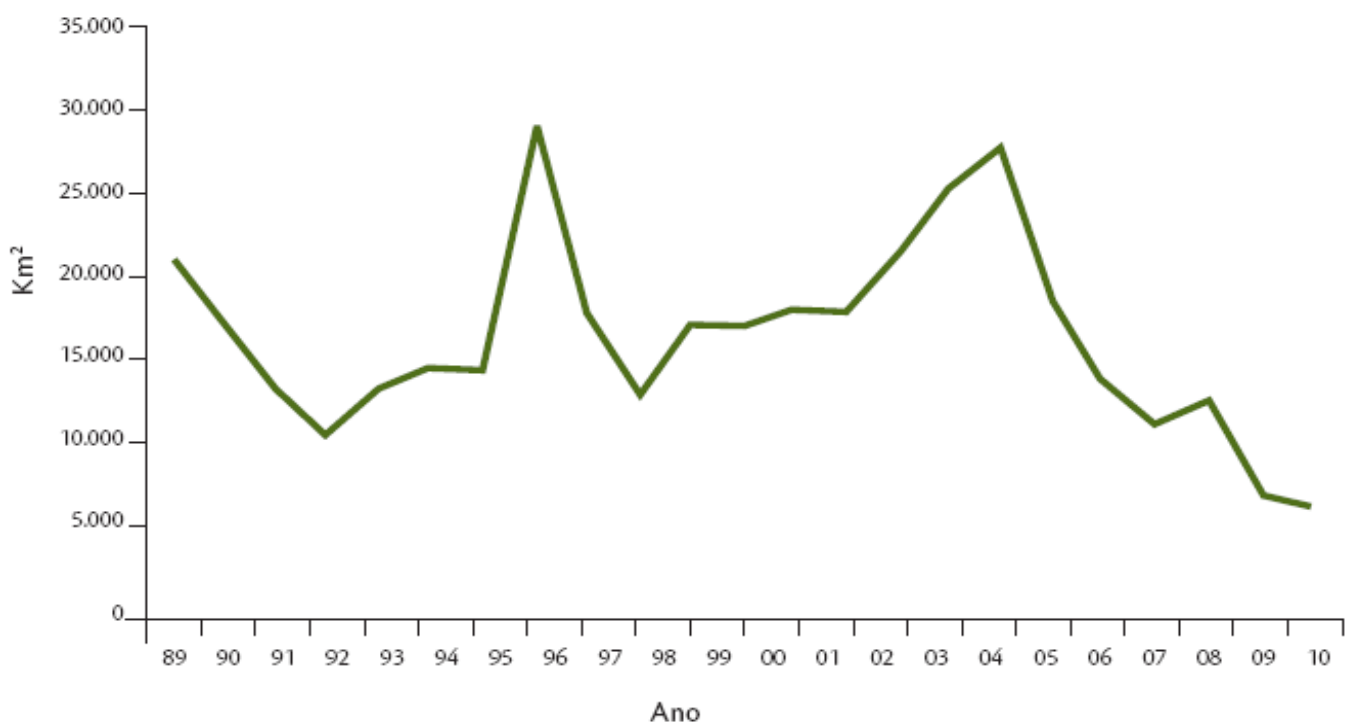

Gráfico 1 - Taxa de Desmatamento na Amazônia Brasileira no período de 1988 a 2010 ( $\mathrm{km}^{2} / \mathrm{ano}$ ), construída com base em dados do Prodes (INPE), 2010. Fonte: IPAM (2011).

No entanto, mesmo diante desta diversidade de iniciativas, em termos gerais, a nova lógica conservacionista não altera o projeto desenvolvimentista da Amazônia, sobretudo nas fronteiras. Na realidade, as duas dinâmicas tendem a coexistir (DUBREUIL, 2005). Ao tempo em que é corrigida uma parte importante dos problemas relacionados ao desmatamento, a nova fase ambiental, em quase nada, afeta a contaminação tóxica do meio ambiente. Em termos gerais, como argumenta Mello (2013), a contaminação de cursos 
d'água com produtos químicos, a degradação de remanescentes florestais pela passagem do fogo, a perda de solos e a ocupação de áreas de risco, continuam a ocorrer como antes.

\subsubsection{A contaminação tóxica do meio ambiente}

Nessa nova configuração ambiental, a intensificação da agropecuária gera outras preocupações ambientais. Desta vez, de caráter mais tecnológico, como agrotóxicos, fertilizantes e vacinas. Dados precisos sobre os padrões de uso de agrotóxicos nas fronteiras não estão disponíveis (SCHIESARI; GRILLITSCH, 2011). Existem apenas alguns estudos pontuais que permitem melhor compreender a dimensão do problema. As pesquisas desenvolvidas em Lucas do Rio Verde, um dos maiores produtores matogrossenses de soja (FÁVERO, 2011; PALMA, 2011; PIGNATI; MACHADO; CABRAL, 2007), nos ajudam nesse sentido. O município, de 37 mil habitantes, consumiu em 2010, cerca de 5,1 milhões de litros de agrotóxicos, em 420 mil hectares de lavouras de soja, milho e algodão (IBGE, 2011; INDEA-MT, 2011; apud MOREIRA et al., 2012). A exposição a agrotóxicos por habitante/ano foi calculada em 136 litros. Resíduos desses produtos tem sido encontrados em amostras de água de poço, de chuva e de ar, coletadas em escolas do município (MOREIRA et al., 2010). O mesmo ocorre com o leite materno. Cerca de dez substâncias agrotóxicas, em diferentes combinações e proporções, foram identificadas em 95\% de 62 amostras analisadas (PIGNATI; MACHADO; CABRAL, 2007).

Além da contaminação local, esse volume de agrotóxicos produz riscos em outras regiões. Os municípios classificados como maiores produtores de soja de Mato Grosso, por exemplo, situam-se nas regiões que abrigam as nascentes de importantes rios da Bacia Amazônica (Teles Pires, Juruena, Tapajós, Araguaia, etc.). Os resíduos dos pesticidas, uma vez lançados nos rios pelas chuvas, são levados à jusante pelo fluxo da água, entram na cadeia alimentar a partir de microrganismos e se concentram ao longo dessa cadeia. No topo da cadeia, atingem principalmente as populações que têm o peixe como um dos principais alimentos, como os povos indígenas, as comunidades ribeirinhas e os pescadores (DROULERS; LE TOURNEAU, 2007).

Os problemas são se limitam apenas a esses. Segundo Schiesari e Grillitsch (2011), as taxas de aplicação de agrotóxicos devem aumentar ao longo do tempo. Para os autores, à medida que a agricultura se intensifica, as populações de insetos e ervas invasoras tendem a crescer, sobretudo devido ao declínio das espécies predadoras e a falta de rotação de culturas. Adicionalmente, o avanço das lavouras de soja sobre as áreas de pastagens, também potencializa o problema. Somente em Mato Grosso, a área plantada com soja aumentou 400\% nos últimos dez anos. Na década de 1990, a produção se concentrava principalmente na região dos Cerrados, no Centro-Sul do Estado, a qual migrou 
cerca de 500 quilômetros para o Norte, encobrindo antigas áreas de pastagem (DOMINGUES; BERMANN, 2012).

\section{Conclusão}

Deste capítulo, extraímos dois elementos importantes para o desenvolvimento da tese. O primeiro é conceitual e se refere a uma noção: o "ciclo de vida" da fronteira. Os aspectos de maior relevância desta categoria são: (i) a percepção da fronteira como uma construção social e (ii) a noção de mudança/evolução da fronteira, ao longo do tempo. Por um lado, isso significa dizer que no esforço de caracterização científica da fronteira é justo observar e incorporar as concepções ou representações da população local sobre a fronteira, uma vez que é delas que emerge a noção de fronteira. Por outro, é preciso estar atento ao potencial dinâmico da fronteira. Este conhecimento nos ajuda a analisar a relação entre as mudanças do meio ambiente e a saúde, objeto de nosso estudo.

O segundo elemento importante oferecido pelo capítulo é concreto. Ele diz respeito às mudanças ambientais que se perpetuaram na fronteira ao longo do tempo. Neste sentido, é importante a percepção de que a transição da fase de ocupação, à fase de consolidação, também engendra uma transformação dos riscos ambientais. No primeiro momento, o risco, produzido pelo avanço da agropecuária, está relacionado ao desmatamento e às queimadas. Estas são formas de degradação biofísica dos ecossistemas. No segundo momento, este risco passa a relacionar-se, sobretudo, ao uso de agrotóxicos. Neste caso, a degradação se torna química. Essas mudanças podem produzir novas configurações em termos de saúde coletiva, tema que é problematizado no capítulo cinco e discutido no capítulo nove. 


\section{Capítulo 3. MEIO AMBIENTE E SAÚDE NA FRONTEIRA: QUE PROBLEMAS?}

\section{Introdução}

Os capítulos precedentes nos ajudaram a compreender as perspectivas adotadas para (i) abordar a relação meio ambiente e saúde e para (ii) analisar a fronteira, sob a perspectiva do "ciclo de vida". Baseados no conhecimento proporcionado por esta revisão, podemos, agora, melhor descrever alguns dos problemas de saúde ambiental da fronteira de maior importância médica-epidemiológica.

O capítulo traz uma breve revisão teórica sobre as doenças de maior prevalência na fronteira: malária, doenças respiratórias, cardiovasculares e neurodegenerativas e cânceres. Por que estas doenças? Em primeiro lugar, porque elas são identificadas pela OMS (Organização Mundial da Saúde) como doenças de caráter ambiental (FISCHER; DODELER, 2009). Em segundo, porque algumas pesquisas epidemiológicas, realizados nas fronteiras agrícolas da Amazônia, tem colocado este conjunto de doenças entre os de maior importância em termos de saúde pública (CARMO et al., 2010; CURVO; PIGNATI; PIGNATTI, 2013; WANIEZ, 2007).

Por que apresentar esta revisão teórica? Três aspectos justificam-na: (i) compreender a participação da degradação ambiental na definição das doenças, (ii) situar estes problemas na fronteira e (iii) subsidiar a análise e a discussão dos resultados, efetivada nos capítulos sete a nove.

Em linhas gerais, esse tema é pouco estudado, seja no que diz respeito à relação meio ambiente e saúde, como no que tange à fronteira. $O$ texto que segue é, portanto, um esforço de reunir informações - muitas vezes produzidas pela ciência básica e, portanto, carregadas de termos técnicos - que oferecem pistas sobre o perfil da saúde ambiental e nos permite melhor compreender essa relação meio ambiente e saúde no contexto de nossa pesquisa. Para isso, apoiamo-nos em estudos realizados nas áreas da biologia, toxicologia e medicina.

\subsection{Devastação, migração e malária}

No Brasil, a malária é uma doença endêmica da Amazônia. Esta característica é determinada, em primeira instância, pela presença autóctone do mosquito transmissor da doença (NEVES, 2006). 
A causa da doença é uma infecção causada por um protozoário do gênero Plasmodium. Os principais transmissores desse protozoário são os mosquitos do gênero Anopheles $^{26}$. Esse inseto é silvestre, mas pode tornar-se urbano, em situações específicas. Ele tem como criadouro grandes coleções de águas limpas e ensolaradas, sobretudo os remansos de rios, lagoas e brejos (NEVES, 2006). Quando esses ambientes são modificados, sobretudo no que diz respeito aos padrões de sombra, chuva, circulação do ar e umidade, a dinâmica e a distribuição do mosquito é alterada. Nestes termos, o aumento da penetração do sol e da concentração de poças d'água, por exemplo, provocado pelo desmatamento, a abertura do dossel da floresta gerada pela extração de madeira, e a diminuição da permeabilidade do solo, podem dobrar a capacidade de multiplicação do mosquito (OLSON et al., 2010; VITTOR et al., 2009; YASUOKA; LEVINS, 2007).

No corpo humano, o protozoário reproduz-se, inicialmente, no fígado e, em seguida, infecta as células vermelhas do sangue, onde realiza uma nova fase da reprodução (figura 3). É a partir dessa fase sanguínea que se manifesta a doença. A reprodução do protozoário, neste caso, ocorre em ciclos que duram 36, 48 ou 72 horas. Quanto mais curto for o intervalo entre um ciclo ${ }^{27}$ e o outro, mais agressiva será a doença e, portanto, maior será o risco de morte. O protozoário da espécie Plasmodium falciparum, é o mais agressivo neste sentido. Ele foi responsável pela maior parte das mortes por malária na fronteira. Outras espécies de importância na Amazônia são Plasmodium vivax e Plasmodium malariae. A identificação da espécie ocorre por meio da análise de sangue. Trata-se de um procedimento rápido e barato. Para efetuá-lo, basta um microscópio, um reagente e um profissional apto para realizar a coleta do sangue e a identificação do parasito nas lâminas microscópicas.

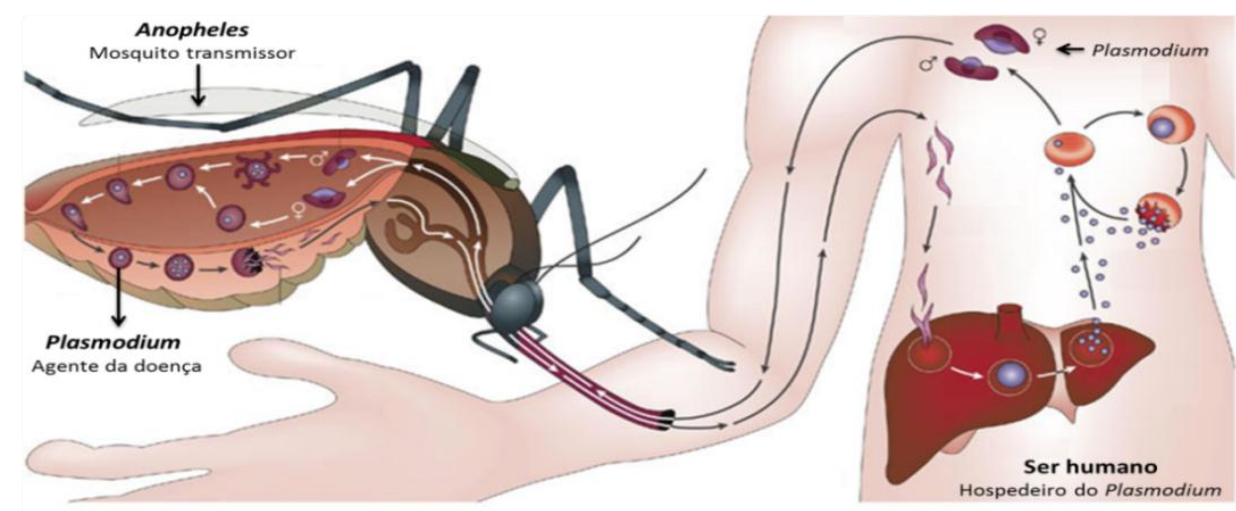

Figura 3 - Ciclo biológico da malária, com destaque para o agente da doença (protozoário de gênero Plasmodium) e o mosquito transmissor (Anopheles). Fonte: Su, Hayton e Wellems (2007) (com adaptações).

\footnotetext{
${ }^{26} \mathrm{Na}$ América do Sul, a espécie mais importante é o Anopheles darlingi (VITTOR et al., 2009).

${ }^{27}$ É no rompimento de cada ciclo reprodutivo sanguíneo que o doente sente calafrios, febre e suores.
} 
Se não for tratada, a malária pode levar o paciente à morte pela interrupção do fornecimento de sangue para os órgãos vitais. Segundo Barbieri (2007, p. 147), "o tratamento da doença envolve o uso de drogas como a cloroquina". Ainda não há uma vacina. Outros métodos de controle são a pulverização de inseticidas, nos ambientes colonizados por mosquitos, e a identificação e o tratamento precoce dos doentes.

A OMS estima que a doença atinja cerca de 200 milhões de pessoas por ano, em todo o mundo, tirando a vida de mais de 600 mil (WHO, 2014c). No Brasil, foram registrados, em 2011, 266 mil casos (BRASIL, 2013a).

A história da doença no Brasil envolve três grandes surtos epidêmicos. Os dois primeiros ocorreram entre o fim do século XIX e o início do século $X X$, fases de grande migração para a Amazônia, estimuladas pela indústria da borracha e pela construção da ferrovia Madeira-Mamoré (CAMARGO, 2003). A terceira grande epidemia ocorreu na fase de expansão da fronteira agrícola, entre os anos 1980 e 2000 (KATSURAGAWA et al., 2008). O crescimento dos números da doença, naquele período, foi alarmante. Em 1970, foram registrados cerca de 52 mil casos. Em 1985, já eram quase 400 mil (SAWYER, 1986). A maior ocorrência foi observada em 1999, com mais de 630 mil doentes (OLIVEIRAFERREIRA et al., 2010). A Amazônia respondia, à época, por 96,3\% deste total (SAWYER, 1986).

Segundo Barata (1995), 63\% dos casos de malária notificados durante os anos 1980, foram produzidos em apenas 20 municípios da região amazônica. A ampla maioria desses municípios estava relacionada a projetos agrícolas e/ou garimpos de ouro. Assumindo uma dimensão mais ampla, afirma-se que a grande epidemia da fronteira resultou das deficiências das instituições responsáveis pelos projetos agrícolas, em termos de planejamento e monitoramento da doença. Paralelamente, se aceita que a epidemia tenha sido gerada pelo "desejo", de uma parte dos agricultores e garimpeiros, pela conquista de novos territórios (CASTRO et al., 2006; SAWYER, 1988).

A grande mobilidade dos trabalhadores, sobretudo para os garimpos, foi significativamente importante para a disseminação da doença. As migrações eram facilitadas pela abertura de grandes rodoviários (Belém-Brasília, Cuiabá-Santarém, etc.), criadas para tornar possível a instalação dos agricultores, nos projetos agrícolas. Estas rodovias facilitavam o trânsito dos garimpeiros de áreas de mineração e assentamentos agrícolas, onde havia alta prevalência da malária, para áreas urbanas e assentamentos mais novos, onde a doença ainda não tinha se estabelecido. Com os trabalhadores infectados, viajava o Plasmodium (BARBIERI; SAWYER, 2007).

O estabelecimento da doença nas novas regiões foi facilitado pela abundância de vetores nas matas. Os mosquitos se estabeleciam nos ambientes não completamente 
sombreados, próximos às bordas da floresta, ao longo dos rios e igarapés e nas águas paradas (CASTRO et al., 2006; SAWYER, 1988). Em locais, como esses, instalavam-se também os garimpeiros. Eles trabalham em permanente exposição aos mosquitos, inclusive nos horários de atividade alimentar desses insetos (final da tarde e início da manhã), dormiam em alojamentos precários e tinham pouco ou nenhum acesso aos serviços de saúde (BARBIERI, 2007).

Acredita-se que foi a partir dos garimpeiros que a doença se espalhou entre os agricultores. As condições do ambiente, moradia e trabalho desse grupo também eram bastante precárias, sobretudo nos primeiros anos da ocupação. Segundo Barata (1995), durante o período das derrubadas, os produtores rurais viviam em acampamentos temporários, construídos, geralmente, nas proximidades dos cursos d'água. A exposição ao mosquito durante o período de trabalho e de descanso era inevitável (CASTRO et al., 2006; SAWYER, 1988). Ademais, a suscetibilidade biológica ${ }^{28}$ dessa população à doença era alta. Isso porque a maior parte das pessoas era originária da região Sul do país, área livre da doença (SAWYER, 1993).

Os indivíduos não imunes corriam alto risco de contrair malária ao adentrarem a Amazônia. Segundo Camargo (2003, p. 29), "se esses indivíduos forem em grande número, podem explodir epidemias". Foi assim nos episódios da migração de paranaenses e gaúchos para os projetos agrícolas que ocuparam as fronteiras. Sem imunidade e sem a "cultura da malária", era grande a suscetibilidade desses imigrantes ao adoecimento. Para se ter uma ideia da dimensão do problema, o Estado de Rondônia chegou a apresentar 300 mil casos de malária em um ano, quando sua população ainda não passava um milhão de habitantes (CAMARGO, 2003).

Populações originárias de áreas endêmicas de malária, que tenham sofrido repetidas infecções pelo Plasmodium, tendem a desenvolver a doença de forma mais branda ou, até mesmo, serem imunes à malária. Isto ocorre porque, nos indivíduos infectados, o protozoário ativa algumas proteínas do sistema imunológico, produzindo anticorpos, que passam a funcionar como "vacinas" naturais contra as novas infeções (BÖHLKE, 1999). No caso da fronteira, esse aspecto parece positivo, no primeiro momento, sobretudo para aqueles que emigraram da região Norte do país, zona endêmica da malária. Contudo, sob o ponto de vista da saúde coletiva, o fenômeno pode ser um problema. As infecções brandas, assintomáticas, não são notadas pelos doentes e, portanto, não são tratadas. Estas

\footnotetext{
${ }^{28}$ Indivíduos ou populações suscetíveis, em termos biológicos, são aqueles não-resistentes (ou menos resistentes) à difusão ou à multiplicação de agentes infecciosos. Por esta razão, contraem mais facilmente uma doença infecciosa, se posto em contato com o seu agente. Entre os fatores que determinam esta suscetibilidade estão os genéticos, nutricionais e imunológicos (NEVES, 2006).
} 
pessoas, mesmo sem sintomas, carregam o parasita no sangue e podem infectar mosquitos, ajudando a disseminar a doença entre outros trabalhadores (CAMARGO, 2003).

A epidemia de malária deixou importantes prejuízos na fronteira. A doença afetou economicamente os trabalhadores rurais e suas famílias, em decorrência do alto custo do transporte e dos tratamentos, bem como, a redução do tempo para investir no trabalho. Esses danos foram sofridos principalmente pelas famílias mais pobres, maiores e mais jovens. Também as pessoas do sexo masculino foram mais afetadas, devido à maior exposição durante o trabalho (SAWYER, 1993). Hoje se sabe que a malária teve importância no abandono de terras, sobretudo nos assentamentos agrícolas mais pobres. Em algumas circunstâncias, ela esteve entre as principais causas do colapso econômico do projeto agrícola (SINGER; CASTRO, 2001).

No curso do tempo, os migrantes sulistas também adquiriram certa imunidade à doença. Paralelamente, as condições de infraestrutura e a oferta de serviços também melhoraram com o tempo. Esses fatores contribuíram para a eliminação da epidemia de malária nas fronteiras (CAMARGO, 2003; DUARTE et al., 2014). Atualmente, o nível da doença é considerado baixo e estável. A exceção está nas margens e áreas adjacentes ao rio Madeira e seus afluentes, onde estão em construção as barragens das hidrelétricas de Santo Antônio e Jirau. Ali se estabeleceu um foco endêmico que perdura por, pelo menos, dois anos (KATSURAGAWA et al., 2008).

Em relação ao futuro da malária na fronteira, alguns autores levantam a questão das mudanças climáticas globais como fenômeno que poderá produzir o recrudescimento da doença nestas regiões. Existem vários cenários neste sentido. Em parte deles, assume-se que as populações dos mosquitos transmissores poderão multiplicar-se em virtude de mudanças no microclima, oscilações climáticas regionais diferenciadas (seca/chuva), entre outros fatores. Entretanto, se aceita, que, na realidade, essas mudanças afetariam o comportamento epidemiológico dessas doenças, entre a população humana, somente em situações de baixa efetividade no acesso a políticas públicas, sobretudo de saúde pública (BARCELLOS et al., 2009).

\subsection{Queimadas e doenças respiratórias}

As doenças respiratórias correspondem às infecções agudas dos pulmões e vias respiratórias superiores e às doenças respiratórias crônicas. As infecções agudas ${ }^{29}$ acometem principalmente as crianças menores de cinco anos e estão associadas,

\footnotetext{
${ }^{29}$ Uma doença aguda é aquela que tem um curso acelerado e intenso. Ela põe em risco a vida da pessoa num prazo curto.
} 
sobretudo, à poluição do ar doméstico, produzida pelo uso de combustíveis sólidos, como madeira e carvão vegetal (WHO, 2014a). As doenças respiratórias crônicas ${ }^{30}$, por sua vez, correspondem a diversas patologias como asma, enfisema pulmonar, bronquite crônica ${ }^{31} \mathrm{e}$ insuficiência respiratória (FISCHER; DODELER, 2009).

Numa perspectiva mundial, essas doenças são responsáveis por mais de quatro milhões de mortes por ano (WHO, 2006a). No Brasil, elas representam aproximadamente $16 \%$ de todas as internações, sendo $50 \%$ delas devido à pneumonia (CARMO; BARRETO; SILVA JR, 2003), e respondem por cerca de 10\% das mortes (NASCIMENTO; MEDEIROS, 2012).

Entre as principais causas dessas patologias está a poluição atmosférica (GOMES, 2002). Tem importância, neste sentido, os gases tóxicos e o material particulado, provenientes da queima parcial de combustíveis fósseis nos motores a combustão, indústrias siderúrgicas e veículos automotivos, principalmente a diesel (MOURA et al., 2008). Contribuem, igualmente, a queima da biomassa vegetal, que, no Brasil, tem origem principalmente no uso do fogo em plantações de cana-de-açúcar, sobretudo em São Paulo, e incêndios florestais da Amazônia (NEPSTAD et al., 2001; RIBEIRO, 2008).

Ao ar livre, a queima de biomassa é um processo de combustão incompleto. Isso significa que a fumaça liberada pela queima de um campo de pastagem ou de uma floresta lança na atmosfera uma série de compostos químicos e resíduos orgânicos com características altamente tóxicas (GONÇALVES; CASTRO; HACON, 2012). Entre os diferentes compostos, os mais nocivos à saúde são conhecidos como "material particulado". A origem, a composição química e o tamanho dessas partículas definem os seus efeitos sobre a saúde humana. As partículas mais lesivas são as $\mathrm{PM}_{2.5}$ (Particulate Matter), assim denominadas em virtude de sua dimensão física (RIBEIRO; ASSUNÇÃO, 2002). Na fronteira, essas partículas são produzidas principalmente no período da seca, entre julho e outubro. Elas representam mais de $60 \%$ de todo o material particulado emitido pelas queimadas (IGNOTTI et al., 2010b).

Ao serem inaladas, as partículas $\mathrm{PM}_{2.5}$ penetram profundamente nos tecidos pulmonares, podendo produzir agravos respiratórios agudos ou crônicos (DE OLIVEIRA; IGNOTTI; HACON, 2011; IGNOTTI et al., 2010b). O efeito agudo se restringe, sobretudo, àquelas pessoas que vivem nos locais mais próximos à área da queimada. As implicações vão desde intoxicações leves até a morte por asfixia. Os efeitos crônicos incluem desde

\footnotetext{
${ }^{30}$ Uma doença crônica é aquela que não põe em risco a vida da pessoa num prazo curto. Ela é duradoura, algumas vezes assintomática, e, de forma geral, tende a afetar a qualidade de vida do doente.

${ }^{31}$ Enfisema pulmonar e bronquite crônica são classificados como doenças pulmonares obstrutivas crônicas ou DPOCs.
} 
complicações ao quadro de asmáticos, a lesões irreversíveis aos pulmões e cânceres (RIBEIRO; ASSUNÇÃO, 2002).

As crianças e os idosos são os grupos mais sensíveis aos efeitos desses poluentes. $\mathrm{Na}$ fase atual da fronteira, durante a estação seca, a internação hospitalar de membros desses grupos aumenta entre 13\% e 20\% (IGNOTTI et al., 2010a, 2010b).

No cenário futuro, especula-se que as mudanças climáticas possam provocar o aumento da frequência de um fenômeno natural, conhecido como "inversão térmica" (BARCELLOS et al., 2009). Esse fenômeno confina grande quantidade de poluentes numa estreita camada da atmosfera, fazendo com que os gases e as partículas nocivas à saúde mantenham-se concentrados próximo à superfície, dentro de um denso nevoeiro, conhecido popularmente como "mormaço" (DUCHIADE, 1992). Acredita-se que a intensificação da ocorrência da "inversão térmica" possa aumentar os níveis de contaminação atmosférica nas regiões onde há grande queima de biomassa e potencializar, por conseguinte, os agravos respiratórios (BARCELLOS et al., 2009).

\subsection{Queimadas e doenças cardiovasculares}

As doenças cardiovasculares são um grupo de doenças do coração e dos vasos sanguíneos que inclui os infartos do miocárdio ${ }^{32}$, insuficiência cardíaca, hipertensão ${ }^{33}$ e outros múltiplos tipos de problemas cardíacos. Elas são a primeira causa de morte no mundo, representando $30 \%$ de todos os óbitos. Para se ter a dimensão do problema, em 2008, esse grupo de doenças respondeu por mais de 17 milhões de mortes. Os acidentes vasculares cerebrais (AVCs) e a doença arterial coronariana ${ }^{34}$ foram as formas mais deletérias (WHO, 2014d).

No Brasil, as doenças cardiovasculares também são a primeira causa de morte. De cada 100 mil óbitos, cerca de 290 ocorrem em decorrência destas doenças. Essa taxa é uma das maiores da América Latina, ultrapassada apenas pela Guiana e pelo Suriname (SCHMIDT et al., 2011).

Em termos gerais, se aceita que fatores como a idade, o histórico familiar e os estilos de vida ${ }^{35}$ sejam os principais responsáveis pela emergência de uma doença cardiovascular. É incluída na lista, a dieta rica em gorduras saturadas e sal, que contribuem com o aumento dos níveis de colesterol e da hipertensão (ISHITANI et al., 2006).

\footnotetext{
${ }^{32}$ Conhecidos popularmente como ataques cardíacos.

${ }^{33}$ Pressão alta.

${ }^{34}$ A doença arterial coronariana se caracteriza por um estreitamento dos pequenos vasos sanguíneos que fornecem sangue e oxigênio ao coração.

${ }^{35}$ Incluem o uso de tabaco, vida sedentária e estresse excessivo, entre outros.
} 
A compreensão da epidemiologia dessas doenças é incompleta e complexa. Segundo Lessa (2004), o que se conhece, em termos de fatores de risco para as doenças cardiovasculares é tão generalizado, que a grande maioria dos fatores etiológicos para doenças do coração são os mesmos para o diabetes, para a doença renal crônica ou para uma variedade de cânceres.

Uma série de estudos tem confirmado a hipótese de que também os contaminantes atmosféricos contribuem para a emergência dessas doenças. No caso dos habitantes das grandes cidades, a poluição do ar gerada pelos automóveis e a indústria, estaria entre as principais causas. No que se refere ao meio rural, são incluídas as queimadas florestais e das áreas de cultivo, as poeiras encontradas em estábulos e paióis, alguns fungos presentes no solo ${ }^{36}$ e os agrotóxicos (FARIA et al., 2006).

Segundo Dockery (2001), enquanto os efeitos relativos do material particulado são maiores para o aparelho respiratório, o número de mortes atribuíveis a esse material é muito maior para as doenças cardiovasculares. O mecanismo pelo qual o material particulado afeta o sistema cardiovascular ainda não foi completamente esclarecido. Os resultados de estudos que utilizaram a exposição a poluentes emitidos por motores a diesel tem sido os mais representativos. Mas, os estudos têm sucesso apenas quando realizados em laboratório. No ambiente natural, diante das diferentes composições do ar, a relação entre a poluição atmosférica e a doença é bem mais difícil de ser determinada (MILLS et al., 2009).

Nunes, Ignotti e Hacon (2013) e Nunes, Neves e Ignotti (2013) produziram os primeiros resultados sobre os efeitos da queima de biomassa sobre a saúde cardiovascular da população da fronteira. As pesquisas verificaram um incremento de $33 \%$ na taxa de mortalidade de pessoas idosas, em decorrência da exposição a partículas $\mathrm{PM}_{2.5}$, produzidas pelas queimadas. As autoras concluíram que a exposição a material particulado contribui com o incremento de mortes por doenças do sistema circulatório e de infartos cardíacos (NUNES; NEVES; IGNOTTI, 2013). Em linhas gerais, os estudos concluíram que as mortes por doenças cardiovasculares estão em ascensão na fronteira e que entre as principais causas está a exposição ao material tóxico emitido pelas queimadas. Os Estados de maior risco para essas doenças são também aqueles em que se observa uma maior taxa de incêndios florestais: Tocantins, Maranhão e Mato Grosso (figura 4).

\footnotetext{
${ }^{36}$ Causadores de um tipo de doença pulmonar denominada paracoccidioidomicose. Ela é produzida pelos esporos do fungo da espécie Paracoccidioides brasiliensis. Eles afetam a saúde dos agricultores principalmente durante o trabalho de remoção do solo, quando os esporos são liberados para a atmosfera.
} 

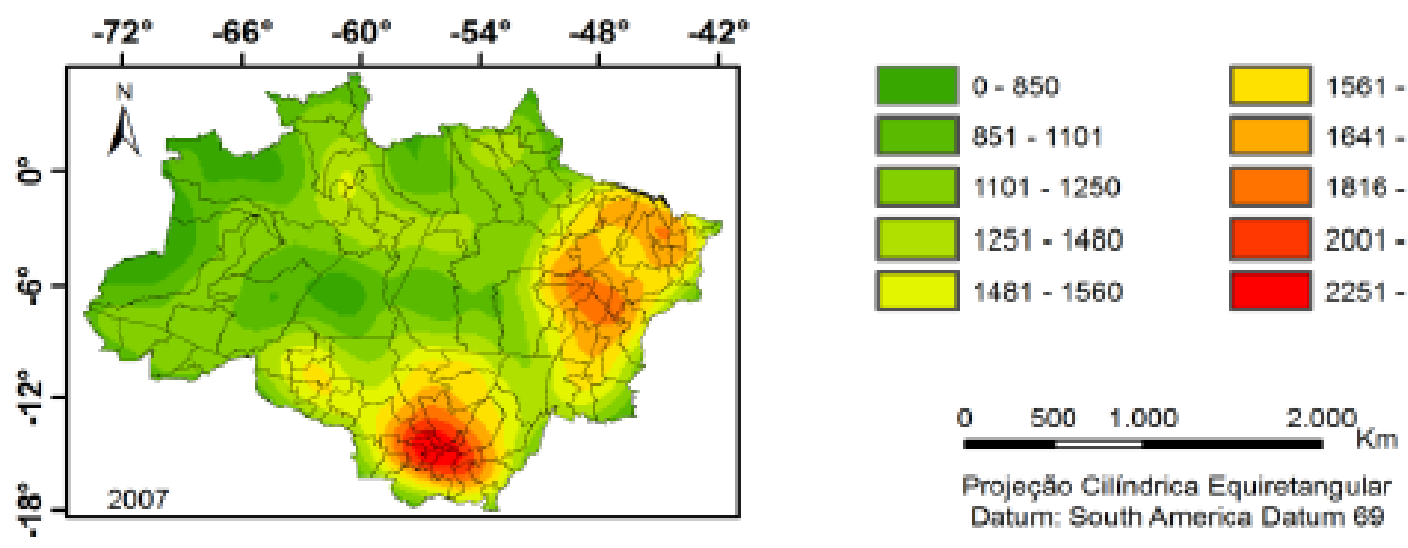

Figura 4 - Modelagem das taxas de mortalidade padronizadas por doenças do aparelho circulatório por 100.000 habitantes, 2007. Fonte: Nunes, Ignotti e Hacon (2013).

\subsection{Agrotóxicos, metais pesados e doenças neurodegenerativas}

Doença neurodegenerativa é um termo genérico usado para identificar uma série de condições que afetam o funcionamento do sistema nervoso de forma crônica e progressiva. De acordo com as estruturas cerebrais afetadas, as doenças prejudicam a motricidade, sensibilidade, linguagem, memória, percepção, habilidades cognitivas, entre outros. Desse grupo, as doenças de maior prevalência são as demências (o mal de Alzheimer, entre outras), e a doença de Parkinson.

A distribuição epidemiológica mundial das demências não está clara. Segundo o Alzheimer's Disease International (ADI), um painel de especialistas dedicado ao estudo de Alzheimer em todo o mundo, os vários tipos $^{37}$ de demência afetariam hoje cerca de 44,4 milhões de pessoas (ADI, 2009). Elas seriam responsáveis pela maior carga das doenças neurodegenerativas, representando entre 60 e $70 \%$ dos casos. No Brasil, de acordo com a OMS, essas doenças se mantêm ocultas e pouco esclarecidas. Em 2006, estimava-se que 729 mil brasileiros as apresentavam, o que representava, à época, cerca de $8 \%$ da população com idade acima de 65 anos. O cenário é de aumento para 1,4 milhões em 2020 e 3,2 milhões em 2040 (WHO, 2006b).

No que se refere à doença de Parkinson, os dados epidemiológicos são bem mais escassos. Estima-se que ela afete aproximadamente 1\% da população mundial com idade acima de 65 anos (NOYCE et al., 2012). Sobre a sua distribuição no Brasil, quase nada se sabe.

Pouco se sabe, também, sobre o comportamento epidemiológico desta doença na fronteira. Em termos científicos, as comprovações são bastante reduzidas. Há, contudo, um

${ }^{37}$ Os tipos de demência mais comuns são: Demência no mal de Alzheimer, Demência vascular e Demência com corpos de Lewy. 
estudo desenvolvido por Medeiros e colaboradores (2014), na região de Manaus, no Estado do Amazonas, que nos ajuda a perceber a magnitude do problema. Nos 12 anos incorporados à pesquisa (1998 a 2009), a prevalência da doença de Parkinson, nesta localidade, aumentou em $900 \%$. Os autores creditam este aumento aos processos de desenvolvimento da região. Destacam, neste sentido, a urbanização, a industrialização e a expansão da fronteira agrícola. Sabe-se que esses processos modificaram os estilos de vida e geraram a contaminação dos ecossistemas com produtos e subprodutos tóxicos e poluentes agrícolas. Segundo os autores, essas mudanças estariam na base da ascensão dessas doenças (MEDEIROS et al., 2014).

A origem das doenças neurodegenerativas é uma grande incógnita. Por enquanto, a informação mais segura é que elas sejam definidas pela genética individual e familiar. No entanto, aos poucos avançam pesquisas em outras direções. Elas lançam perguntas sobre a participação dos produtos químicos, tais como agrotóxicos e metais pesados, ou, os príons $^{38}$.

Nos países da Europa e nos Estados Unidos, os estudos são bem mais frequentes que na América Latina. Dentre as principais abordagens está a relação entre as doenças neurodegenerativas e a exposição laboral a agrotóxicos. Os agricultores são a população mais estudada. Os avanços são significativos. Na França, por exemplo, a doença de Parkinson é oficialmente reconhecida como uma doença profissional relacionada à agricultura (GOUVERNEMENT FRANÇAIS, 2012). Esse reconhecimento se apoia em estudos que evidenciam a relação entre o uso de agrotóxicos e o risco de desenvolver a doença.

\subsubsection{Agrotóxicos e doença de Parkinson}

Os agrotóxicos são uma ampla gama de substâncias usadas para controlar insetos, ervas invasoras e fungos. Eles são classificados de acordo com o organismo alvo, como: inseticidas (combate insetos), herbicidas (ervas invasoras), fungicidas (fungos) ou fumigantes (vermes nematoides). Entre os inseticidas encontram-se os organoclorados ${ }^{39}$, como o DDT, o percursor das denúncias de Rachel Carson (1962), sobre a redução da população de pássaros nos Estados Unidos da década de 1970. Esse grupo é o mais estudado em relação à doença de Parkinson (KAMEL; HOPPIN, 2004).

\footnotetext{
${ }^{38}$ Príons são partículas de proteína produzidas pelos neurônios, podem se transmitidas de um ser para outro e, eventualmente, provocam algum tipo de doença no cérebro, como a demência. Os príons passaram a ser investigados a partir do evento da "doença da vaca louca", uma encefalopatia capaz de ser transmita ao ser humano.

${ }^{39} \mathrm{DDT}, \mathrm{BHC} \mathrm{C}^{39}$, Aldrin, Endrin e Endossulfan, etc.
} 
No Brasil, os agrotóxicos são utilizados em grande escala por vários setores produtivos. As aplicações mais intensivas são realizadas em sistemas de monocultivo de grandes extensões e em pequenas e médias produções hortícolas e frutícolas (SILVA et al., 2005). Os números são intimidantes. Estima-se que, somente em 2010, tenham sido aplicados nas lavouras produtoras de cereais e nas pastagens, de todo o país ${ }^{40}$, cerca de 830 milhões de litros de agrotóxicos. Os mais consumidos foram os herbicidas $(60 \%)$ e inseticidas (20\%) (CARNEIRO; RIGOTTO; PIGNATI, 2012).

$\mathrm{Na}$ produção de soja, o mais consumido é o herbicida Glifosato $^{41}$, sobretudo na produção de variedades geneticamente modificadas (OGMs). Pela classificação da ANVISA (2014a), a toxicidade desse composto é considerada moderada. Estudos que tratam de seus efeitos nocivos à saúde dão destaque ao seu potencial mutagênico, que pode desencadear a formação de cânceres e a diminuição da fertilidade. A maior parte dos testes é realizada com cobaias, principalmente camundongos (GRISOLIA, 2005).

Nas pastagens, os herbicidas mais usados são o Tordon $^{42}$ e o Gramoxone $200^{43}$ (SILVA et al., 2005). Esses produtos provocam a morte ou impedem o desenvolvimento das plantas dicotiledôneas, conhecidas pelos agropecuaristas, como "folhas largas". Como resultado, após a pulverização, sobrevivem apenas as gramíneas. A aplicação é feita diretamente nas folhas com uso de um pulverizador manual ou acoplado a um trator. Estima-se que apenas 20 a $40 \%$ do produto pulverizado seja absorvido pelas plantas, o restante fica disperso no ar ou penetra no solo, de onde é carreado pelas chuvas para os sistemas aquáticos (PROCÓPIO et al., 2008).

Esses produtos são classificados, pela ANVISA (Agência Nacional de Vigilância Sanitária) (2014b, 2014c), como altamente tóxicos. Eles estão presentes, inclusive, em muitas listas de produtos carcinogênicos. Além disso, vale relembrar que o Tordon possui componentes do "agente laranja", utilizado pelos norte-americanos como arma química, durante a guerra do Vietnã (GRISOLIA, 2005).

Segundo Kamel e Hoppin (2004), a maioria dos tipos de agrotóxicos pode ser neurotóxica, mas apenas alguns deles foram estudados em detalhe. A literatura oferece fortes evidências da associação entre o Tordon e o paraquate ${ }^{44}$, e a doença de Parkinson (DE LAU; BRETELER, 2006; TANNER et al., 2011). O mesmo pode ser dito em relação aos

\footnotetext{
${ }^{40} \mathrm{O}$ Brasil é considerado, pelas suas dimensões, o país onde o consumo de agrotóxicos é o maior do mundo.

${ }^{41}$ Fórmula: Roundup, produzido pela Monsanto.

${ }^{42}$ Fórmula: $2,4-D+$ picloram.

${ }^{43}$ Fórmula: paraquate + diuron. Trata-se de um herbicida usado no combate as ervas invasoras e na dessecação de culturas de soja, milho e cana-de-açúcar.

${ }^{44}$ Também usado para controlar ervas invasoras.
} 
inseticidas organoclorados ${ }^{45}$ : DDT, BHC (hexaclorobenzeno), Aldrin e Endrin, retirados do mercado em meados da década de 1980, e Endosulfan, proibido em 2013. Estudos mostraram que o cérebro dos parkinsonianos apresenta níveis bastante superiores de organoclorados do que o cérebro de pessoas sãs (FLEMING et al., 1994).

Os inseticidas organoclorados são substâncias de alta resistência à degradação química e biológica e têm, portanto, longa persistência no ecossistema ${ }^{46}$. Além disso, eles possuem alta solubilidade em gorduras, o que facilita a sua acumulação nos organismos vivos. Ao serem lançados no meio ambiente, são transportados em grandes quantidades pelas chuvas, atingindo águas superficiais. Também podem infiltrar no solo, atingir as águas subterrâneas e contaminar a água de poços (FLORES et al., 2004). A partir da água, esses compostos contaminam alimentos, sobretudo vegetais, e acumulam-se nos diversos níveis da cadeia alimentar, especialmente na carne de peixes, aves e no leite de vaca (CORBI et al., 2006).

A contaminação humana pode ocorrer a partir do contato obtido durante o manuseio dos pesticidas, no momento das pulverizações, ou por contaminação alimentar e atmosférica (por vapores). Ao serem inalados ou ingeridos, esses compostos se concentram nos tecidos biológicos, tendo como alvo principal o sistema nervoso central. Em torno de uma década depois da primeira exposição, a doença de Parkinson pode se manifestar, embora permaneça assintomática por mais 5 a 10 anos. Na maioria dos agricultores ou trabalhadores rurais que a desenvolvem, isso ocorre entre os 45 e 70 anos de idade (TANNER et al., 2011).

As pessoas que trabalham diretamente com agrotóxicos ou que residem nas proximidades das lavouras, onde eles são aplicados os pesticidas, apresentam um risco até $70 \%$ maior de desenvolverem a doença de Parkinson (ASCHERIO et al., 2006). Sabe-se hoje que o trabalhador rural, sua família e as populações que habitam nas redondezas das unidades produtivas são as mais afetadas (FERRAZ et al., 1996; SILVA et al., 2005).

\subsubsection{Mercúrio, mal de Alzheimer e doença de Parkinson}

O mercúrio é um metal pesado, tóxico e nocivo à saúde, que ocorre naturalmente na crosta terrestre. Os fenômenos naturais, como a erosão e as erupções vulcânicas, e as atividades antrópicas, como a fundição de metal e a produção industrial, podem levar à

\footnotetext{
${ }^{45}$ Os compostos organoclorados apresentam uma molécula de cloro ligada a uma cadeia de carbono. Entre as suas principais características estão: a alta persistência no ambiente, a alta solubilidade em gorduras e os efeitos carcinogênicos.

${ }^{46} \mathrm{Em}$ alguns rios amazônicos, como no Teles Pires, em Mato Grosso, ainda podem ser encontrados resíduos do DDT usado no combate ao mosquito transmissor da malária, nos anos 1980 (D'AMATO; TORRES; MALM, 2007; LOIOLA; MANGABEIRA DA SILVA; TAUIL, 2002).
} 
contaminação do ambiente com o metal (TCHOUNWOU et al., 2003). Na Amazônia brasileira, são reconhecidas duas formas de ocorrência dessa contaminação: (i) a partir do uso de mercúrio nos garimpos de ouro (HACON et al., 1997a; LACERDA; DE SOUZA; RIBEIRO, 2004) e (ii) pela lixiviação do metal presente nos solos (ROULET et al., 1998, 1999).

Nos garimpos da Amazônia, o mercúrio foi amplamente usado, durante a mineração, para formar uma amalgama com as partículas de ouro, separando-o do cascalho. Nesta operação, o mercúrio alcança o meio ambiente por dois caminhos: (i) durante o processo de separação do ouro do cascalho, nas zonas de coleta do minério, geralmente às margens dos rios e igarapés, e (ii) pela fusão do ouro (amalgamação), nos postos de venda, localizados na zona urbana (figura 5) (CAHETÉ, 1998; HACON et al., 1995). Seguindo o primeiro caminho, o metal deposita-se nos solos, contamina os corpos d'água e pode ser transportado por longas distâncias, até entrar na cadeia alimentar aquática. No segundo, o aquecimento do metal produz vapores altamente tóxicos que afetam a saúde da população diretamente exposta (HACON et al., 1997a) e contaminam a água da chuva.

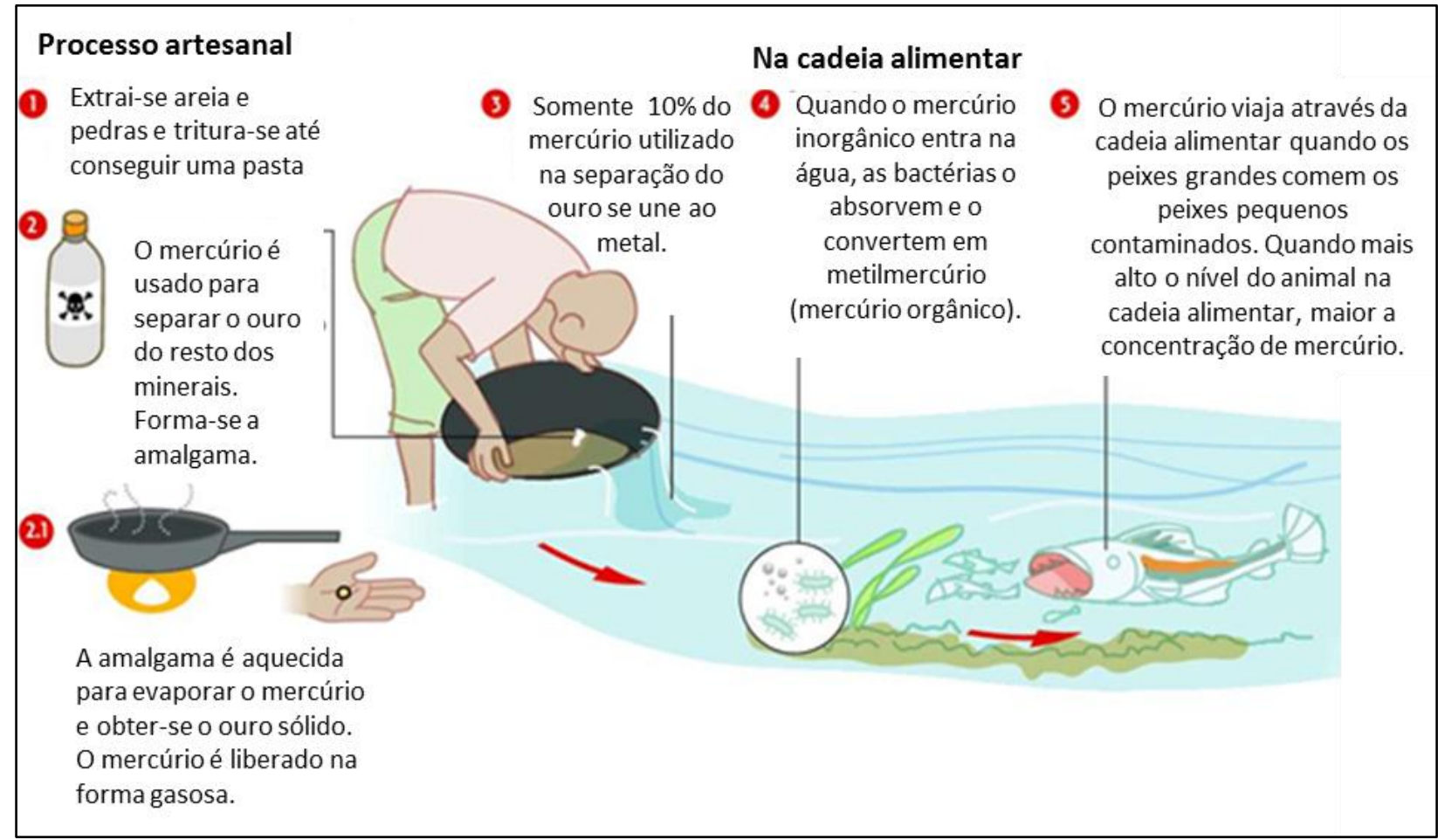

Figura 5 - Formas de contaminação do ambiente com mercúrio, a partir da mineração artesanal de ouro. Fonte: PNUMA (2002) (com adaptações).

A "corrida pelo ouro", que ganhou a Amazônia no final da década de 1970, fundando Serra Pelada, no Estado do Pará, e outras regiões importantes de garimpo, deixou um volume enorme de mercúrio no ecossistema amazônico. Alguns estudos sugerem que, somente no ano de 1989, 160 toneladas de mercúrio tenham sido usadas nos garimpos. 
Deste total, entre 20 e $25 \%$ do mercúrio ficou retido no ecossistema ainda na primeira fase de separação do ouro, realizada em campo. O percentual restante (75 a 80\%) volatilizou-se durante a fase de queima do amalgama, nos pontos de venda de ouro (VILLAS BÔAS, 1997).

A suspensão das atividades dos garimpos não interrompe a circulação do mercúrio nos ecossistemas naturais (LACERDA; MALM, 2008). Embora em menor concentração, os rejeitos contaminados deixados nos sítios de garimpagem e os resíduos que permaneceram no solo continuam sendo removidos para os corpos d'água pela ação das chuvas (HACON et al., 1997a). Na água, transformam-se em metil-mercúrio e são incorporados à cadeia alimentar, concentrando-se especialmente em peixes carnívoros (DE OLIVEIRA SANTOS et al., 2002).

No entanto, esta forma de contaminação não é a única. Estudos recentes indicam que os solos amazônicos acumulam quantidades significativas de mercúrio, associado à oxihidróxidos de ferro (GUIMARÃES, 2001; GUIMARÃES; MERGLER, 2011; ROULET et al., 1998, 1999). O metal seria removido do solo e carreado para os rios a partir da derrubada da floresta, a aração do solo, a erosão e a queima da vegetação (ROULET et al., 1998, 1999). Dentre estes, a queima da floresta é considerada a forma mais nociva em termos de contaminação mercurial. Estima-se que, por ano, essa prática libere cerca de 90 toneladas de mercúrio para a atmosfera. Grande parte da contaminação dos ecossistemas aquáticos viria deste fenômeno (GUIMARÃES, 2001; ROULET et al., 1999).

Ao ser deposto nos rios, o mercúrio metálico é transformado em metil-mercúrio e incorporado à cadeia alimentar, a partir de algas e plantas aquáticas. A concentração do metal, nesses organismos é baixa. Nos peixes, que as consomem, ela fica um pouco mais elevada. Nos peixes que consomem estes peixes, ainda mais alta. Assim, o mercúrio vai se concentrando à medida que é consumido por animais que ocupam posições mais altas da cadeia alimentar. No topo dessa cadeia, espécies carnívoras, como o pintado ${ }^{47}$ ou a piranha $^{48}$, amplamente consumidos pelas populações amazônicas, apresentam concentrações de mercúrio até um milhão de vezes superiores às da água (WASSERMAN; HACON; WASSERMAN, 2001).

Os danos provocados à saúde, pelo mercúrio, são sistêmicos, ou seja, atingem variados órgãos e sistemas. Eles também são difíceis de serem diagnosticados, uma vez que produzem sintomas que podem ser facilmente confundidos com outras doenças. De forma geral, a principal consequência da exposição ao mercúrio vem do acúmulo do metal

\footnotetext{
47 Nome popular dado a duas espécies de peixe carnívoras, encontradas na Amazônia: Pseudoplatystoma coruscans e Pseudoplatystoma fasciatum.

${ }^{48}$ Peixe carnívoro que, na Amazônia, se distribui em 36 espécies.
} 
no sistema nervoso central, sobretudo em crianças. Ele pode levar à diminuição do desempenho da função motora e da memória, produzindo perturbações da atenção, da coordenação motora fina ${ }^{49}$ e da memória verbal. Além disso, o mercúrio é associado a vários tipos de distúrbios, de ordem neurológica, nefrológica ${ }^{50}$, imunológico, cardíaca, reprodutiva e até mesmo genética (ZAHIR et al., 2005).

Estudos realizados nas regiões de garimpo de ouro da Amazônia brasileira e da Guiana Francesa mostraram que os níveis de exposição das populações locais ao mercúrio são notavelmente superiores aos encontrados em outras partes do mundo. Em relação à saúde da população exposta, as pesquisas mostram um ligeiro déficit em componentes funcionais da memória visuoespacial, na motricidade das pessoas expostas (CORDIER et al., 2002; GRANDJEAN et al., 1999). O aumento destes danos acompanhava o aumento do nível de exposição ao mercúrio (BOUDOU et al., 2006). Em populações ribeirinhas da região do médio rio Tapajós, no Estado do Pará, a alta exposição ao mercúrio, a partir do consumo de peixes carnívoros, tem sido associada a uma sutil diminuição do desempenho psicomotor, afetando os movimentos e a visão (DOLBEC et al., 2000; LEBEL et al., 1998).

Recentemente, a exposição a mercúrio também tem sido associada também às doenças de Alzheimer e Parkinson. Os mecanismos pelos quais o metal gera essas enfermidades ainda são pouco esclarecidos. É difícil determinar sua ação no organismo, porque os compostos de mercúrio são capazes de atuar em muitos âmbitos e por meio de diversos mecanismos toxicológicos. Em linhas gerais, sabe-se que as doenças emergem após um prolongado período de latência, isto é, muito tempo após a exposição ao metal (CRESPO-LÓPEZ et al., 2005).

\subsection{Cânceres}

Câncer é um distúrbio do crescimento e do comportamento celular que pode afetar qualquer órgão ou tecido humano. Trata-se de um conjunto que reúne mais de 100 tipos diferentes de doenças.

Os cânceres são um importante problema de saúde pública, principalmente nos países em desenvolvimento. Dos cerca de oito milhões de pessoas que morrem todo ano, vítimas de câncer, 60\% residem em países da África, Ásia, América Central e América do Sul (WHO, 2014b).

\footnotetext{
${ }^{49}$ Escrever, coordenar os movimentos das mãos e dos olhos, criar peças de arte, mover olhos e lábios são alguns exemplos.

${ }^{50}$ Ligada ao sistema urinário.
} 
O diagnóstico de novos casos da doença, nestes países, comporta-se de forma ascendente. No Brasil, o Ministério da Saúde estima que, em 2014, mais de 580 mil pessoas descobrirão a doença (BRASIL, 2013b). Os tumores mais frequentes são da próstata, pulmão, estômago, cólon e reto e esôfago na população masculina. Entre as mulheres, o câncer de mama é a primeira causa de morte, seguido pelos cânceres de colo uterino, cólon e reto, pulmão e estômago (BRASIL, 2014).

Sob o ponto de vista da saúde pública, a incidência da doença é preocupante. A prevalência mundial aumentou em $89 \%$ de 1980 a 2005. Até recentemente, este aumento era explicado pelo crescimento demográfico e o envelhecimento da população. Hoje se sabe que mais de $80 \%$ dos cânceres podem ser determinados pelo meio ambiente (CABANES; ROUSSEL, 2010).

Entre os agentes cancerígenos figuram os agrotóxicos. Entretanto, sob o ponto de vista epidemiológico, a avaliação do potencial carcinogênico desses compostos é extremamente complicada. Para Jobim e colaboradores (2010), as dificuldades inerentes às pesquisas são inúmeras. De um lado, estão os problemas associados aos produtos em si, que são bastante heterogêneos e, na prática, aplicados de formas múltiplas. De outro, a dificuldade em investigar a exposição humana, devido principalmente à natureza e à diversidade dessa exposição.

Entre os herbicidas, sabe-se que o Glifosato, embora apresente um grau moderado de toxicidade, pode provocar alterações como o retardo de crescimento, aumento do tamanho do fígado e inflamações gástricas, entre outros. Estes quadros podem incluir a formação de tumores (GRISOLIA, 2005). Estudos realizados com agricultores, e outras pessoas expostas ao herbicida, têm demonstrado que esta exposição está relacionada com aumento do risco de câncer do sistema linfático (COX, 2004).

Recentemente foram identificados alguns outros mecanismos pelos quais o Glifosato pode causar câncer. Entre eles, podemos citar os resultados das experiências realizadas por pesquisadores da Universidade de Minnesota (LIN; GARRY, 2000). Eles conseguiram reunir provas da ação do herbicida sobre a divisão celular, concluindo que o Glifosato é o precursor de vários tipos de câncer de mama. Em um estudo semelhante, Marc, MulnerLorillon e Bellé (2004), concluíram que o herbicida tem capacidade de gerar células tumorais e cânceres em humanos. O risco é elevado para as pessoas que inalam o produto durante ou após a sua pulverização. Neste grupo, estão incluídos os trabalhadores e as pessoas que habitam na vizinhança das propriedades rurais.

Em relação ao Tordon, estudos indicam que o Picloram, um de seus componentes químicos, pode causar câncer no fígado, na tiroide e nos rins. A doença resulta de uma prolongada exposição ao herbicida, em baixas concentrações, ou de uma intensiva e rápida 
contaminação. Estudos desenvolvidos pela U.S. Environmental Protection Agency (EPA), agência reguladora do meio ambiente dos Estados Unidos, indicam que a principal forma de contaminação é alimentar. Ela advém do consumo de carne ou leite, produzidos por gado que se alimenta de pastagens tratadas com Picloram. Os fatores de risco não incluem a exposição à água, ar ou superfícies contaminadas. As pesquisas foram realizadas com animais de laboratório (COX, 1998).

É possível reunir vários outros estudos que comprovam a relação entre os agrotóxicos e os cânceres. Contudo, em relação a esta questão na fronteira, continuamos sabendo pouco.

\section{Conclusão}

Este capítulo ofereceu importantes pistas para compreender os fatores que levaram à emergência e prevalência da malária na região. Há fortes indicativos de que a doença esteve relacionada, entre outros fatores, à dinâmica estabelecida pelo desmatamento.

Em segundo plano, é possível perceber a importância das doenças crônicas para a saúde pública regional, sobretudo no que diz respeito aos agravos respiratórios e cardiovasculares. Notou-se que a prevalência destas doenças é, provavelmente, o resultado do volume e do nível de toxicidade encontrada na fumaça das queimadas florestais. Em relação às doenças neurodegenerativas e dos cânceres, há indicativos de uma relação com a exposição a agrotóxicos e a metais pesados, como o mercúrio, entre outros.

Em síntese, este contexto subsidia a pesquisa sobre a relação entre as doenças e a degradação ambiental. No capítulo seguinte, tais temas são tratados em relação à área de estudo. 
- Segunda Parte -

DELINEAMENTO DA PESQUISA:

INTERDISCIPLINARIDADE E PARTICIPAÇÃO 


\section{Capítulo 4. CARACTERIZAÇÃO DA ÁREA DE ESTUDO: OCUPAÇÃO E DEGRADAÇÃO AMBIENTAL EM ALTA FLORESTA}

\section{Introdução}

Este capítulo apresenta as características principais da área de estudo. O município de Alta Floresta localiza-se ao Norte do Estado de Mato Grosso, na divisa com o Estado do Pará. A ocupação desta região foi efetivada pela iniciativa privada, a partir da aquisição de terras devolutas e ocorreu no ano de 1973. Trata-se de uma área de 8.976,177 $\mathrm{Km}^{2}$ ocupada, atualmente, por cerca de 50 mil habitantes (IBGE, 2014a).

O objetivo do capítulo é apresentar alguns elementos para que conheça as principais características da área de estudo. Isso é feito a partir de um breve resgate da história da ocupação dessa fronteira e da apresentação das condições socioeconômicas encontradas atualmente. Na primeira parte, fazemos uma rápida revisão dos eventos que levaram à alternância das fases de ocupação: quais foram os dispositivos e meios que promoveram a ocupação dessa região e como ela se deu. $\mathrm{Na}$ segunda, são apresentados alguns indicadores sociais e econômicos, os quais revelam com mais detalhes as caraterísticas socioeconômicas atuais do município de Alta Floresta, tendo como destaque os atuais problemas de saúde.

\subsection{Contextualização histórica: A ocupação de Alta Floresta}

\subsubsection{A ocupação e a expropriação indígena}

A região de Alta Floresta pertencia aos povos indígenas Kreenakarore, Apiaka, Munduruku e Kayabi. O território dos Kreenakarore foi atravessado pela BR-163, na década de 1970. Os confrontos entre indígenas e não-indígenas, durante da construção da rodovia, provocaram uma grande queda populacional, principalmente por doenças infecciosas como sarampo e gripe. No início de 1975, a FUNAI (Fundação Nacional do Indígena) iniciou a sua remoção para o Parque Indígena do Xingu. Restavam 79 sobreviventes, de uma população 350 pessoas, contada em fevereiro de 1973 pelos irmãos Villas Boas, os primeiros a fazerem contato com a etnia em Mato Grosso (EWART, 1998; MARTINS, 1996).

Os Apiaka, Munduruku e Kayabi tinham sofrido violentos decréscimos populacionais na virada do século XIX para o século $X X$, devido às epidemias e os massacres provocados por trabalhadores das frentes extrativistas da borracha (1879 a 1912). Na década de 1970, 
quando a INDECO (Integração, Desenvolvimento e Colonização) iniciou a abertura das áreas, eles tinham sido transferidos por missionários da Igreja Católica para as margens dos rios Juruena, Teles Pires e afluentes. Atualmente, muitos descendentes são originários de matrimônios entre diferentes etnias ou com trabalhadores imigrados durante o ciclo da borracha (TEMPESTA, 2010a).

Quando os primeiros migrantes chegaram a Alta Floresta, praticamente não existiam mais povos indígenas na região. A grande maioria havia sido expulsa, massacrada ou transferida para o Parque Indígena do Xingu. Há relatos de que a INDECO tenha "limpado" a área, para receber as famílias de agricultores (JATENE, 1983). Atualmente, a maior parte das aldeias está situada no município e Apiacás, no extremo Norte de Mato Grosso, divisa com o Estado do Pará e do Amazonas. Estes povos estão vulneráveis ao avanço das fazendas de gado e à construção de um complexo de cinco usinas hidrelétricas, nos rios Teles Pires e Tapajós, na porção Sul. Ao Noroeste e Leste, os seus territórios são limitadas por um grande complexo de unidades de conservação, formado pelo Parque Nacional do Juruena, a Floresta Nacional de Jatuarana, o Mosaico do Apuí, um conjunto nove unidades de conservação do Estado do Amazonas, e o Parque Igarapé do Juruena, do Estado de Mato Grosso.

\subsubsection{A dinâmica da ocupação da fronteira agrícola de Alta Floresta}

A ocupação da fronteira agrícola de Alta Floresta está relacionada a um contexto maior do setor agrícola e dos interesses nacionais das décadas de 1960/70. Nesta fase, o mundo vivenciou a modernização agrícola ("Revolução Verde") e a expansão da globalização. No Brasil, esses fatores levaram à redescoberta do setor agrícola como vetor de crescimento econômico, à reorganização dos espaços produtivos e à adoção de políticas orientadas para o mercado agroexportador. Esse modelo alterou a dinâmica agrícola principalmente nos Estados da região Sul e do Nordeste, onde produziu concentração fundiária, reorientação das atividades produtivas e expulsão de mão-de-obra do campo (COY, 1996; LE BORGNE-DAVID, 1998; LÉNA, 1992).

À mesma época, o governo militar assumiu a ocupação da Amazônia como uma prioridade. Ela serviria de "válvula de escape" para aliviar as pressões sociais ligados à crescente concentração da terra em outras regiões (BECKER, 1988). Além disso, segundo Foucher (1974) e Le Borgne-David (1998), o governo militar via na ocupação da Amazônia uma estratégia de integração nacional, diante dos riscos de uma desapropriação da região, desejada pelo governo dos Estados Unidos e demonstrada pelos grandes projetos de 
prospecção mineral. Outro fator colocado em evidência, na época, era o risco do território amazônico abrigar focos revolucionários oriundos dos países vizinhos (BECKER, 2001).

Esse conjunto de fatores levou à planificação dos grandes projetos de ocupação agrícola. Na ótica do governo da época, era preciso viabilizar o processo de ocupação das "terras livres", que se destinariam à produção de alimentos e matérias-primas (BECKER, 1988), ao tempo em que protegeria a Amazônia contra uma possível "internacionalização" (LE BORGNE-DAVID, 1998). A Amazônia se tornara uma nova reserva de espaço, uma "terra sem homens para homens sem terra" e uma estratégia da ditadura militar que deveria "integrar para não entregar" o domínio do território a outros países. Esses foram os dois slogans que orientaram a expansão da fronteira agrícola para as terras amazônicas.

A primeira fase de ocupação, iniciada na década de 1960, foi estimulada pela criação do Banco de Crédito da Amazônia (atual BASA - Banco da Amazônia), da SUDAM (Superintendência do Desenvolvimento da Amazônia) e do Programa de Integração Nacional (PIN). Esses dispositivos orientaram a construção das rodovias Transamazônica e Cuiabá-Santarém (BR-163), possibilitando a ocupação espontânea das terras do Estado do Pará e de Mato Grosso por pequenos produtores, oriundos principalmente dos Estados do Nordeste brasileiro (MIRANDA, 1990).

A segunda fase, na década de 1970, foi orientada pelo PROTERRA (Programa de Redistribuição de Terras e de Estímulos à Agroindústria do Norte e do Nordeste) e o POLAMAZÔNIA (Programa de Polos Agropecuários e Agrominerais da Amazônia). Esses programas concentraram a aplicação de recursos em projetos de colonização privada, dirigidos por empresas ou cooperativas que assumiam o processo de ocupação demográfica e econômica da região (MIRANDA, 1990). O objetivo era impedir a livre ocupação por "aqueles que não tinham capital para investir produtivamente na área de colonização" (GUIMARÃES NETO, 2002, p. 93). As terras eram destinadas, portanto, somente àqueles que possuíam algum recurso financeiro.

Segundo Jepson (2006), entre 1970 e 1990, 35 empresas ou cooperativas, organizadas em 104 projetos, promoveram a ocupação de 39\% da área total da fronteira agrícola da Amazônia Legal. Mato Grosso foi um dos Estados de maior significância em relação à implantação dos projetos agrícolas privados. Mais de 100 cidades, localizadas, sobretudo entre o Centro e o Norte do Estado, nasceram desta dinâmica (FERREIRA; MOURA E SILVA, 2008). Somente na porção Norte do Estado de Mato Grosso, a população aumentou em 12 vezes em um período de aproximadamente 20 anos. De 60.000 habitantes, registrados no recenseamento do IBGE de 1970, a população passou para 710.000 na pesquisa de 1991 (COY, 1996). 
A estratégia usada pelo governo para transferir o processo de ocupação dessas terras à iniciativa privada era a licitação pública de grandes lotes de terras devolutas. O primeiro destes certames ocorreu no ano de 1973 e resultou no repasse de dois milhões de hectares a quatro companhias de colonização - COLNIZA (Colonização Comércio e Indústria), RENDANYL (Indústria de Rendas), Juruena e INDECO -, a quem coube a completa implantação dos projetos agrícolas (MORENO, 1999).

Segundo Moreno (1999), das quatro companhias vencedoras, apenas a INDECO cumpriu os compromissos impostos pelo edital. Ela havia adquirido 400 mil hectares nas proximidades de outra área de 494 mil hectares, que já pertencia à empresa, localizada no extremo norte do Estado, atual município de Alta Floresta (figura 6) (JOANONI NETO, 2007).

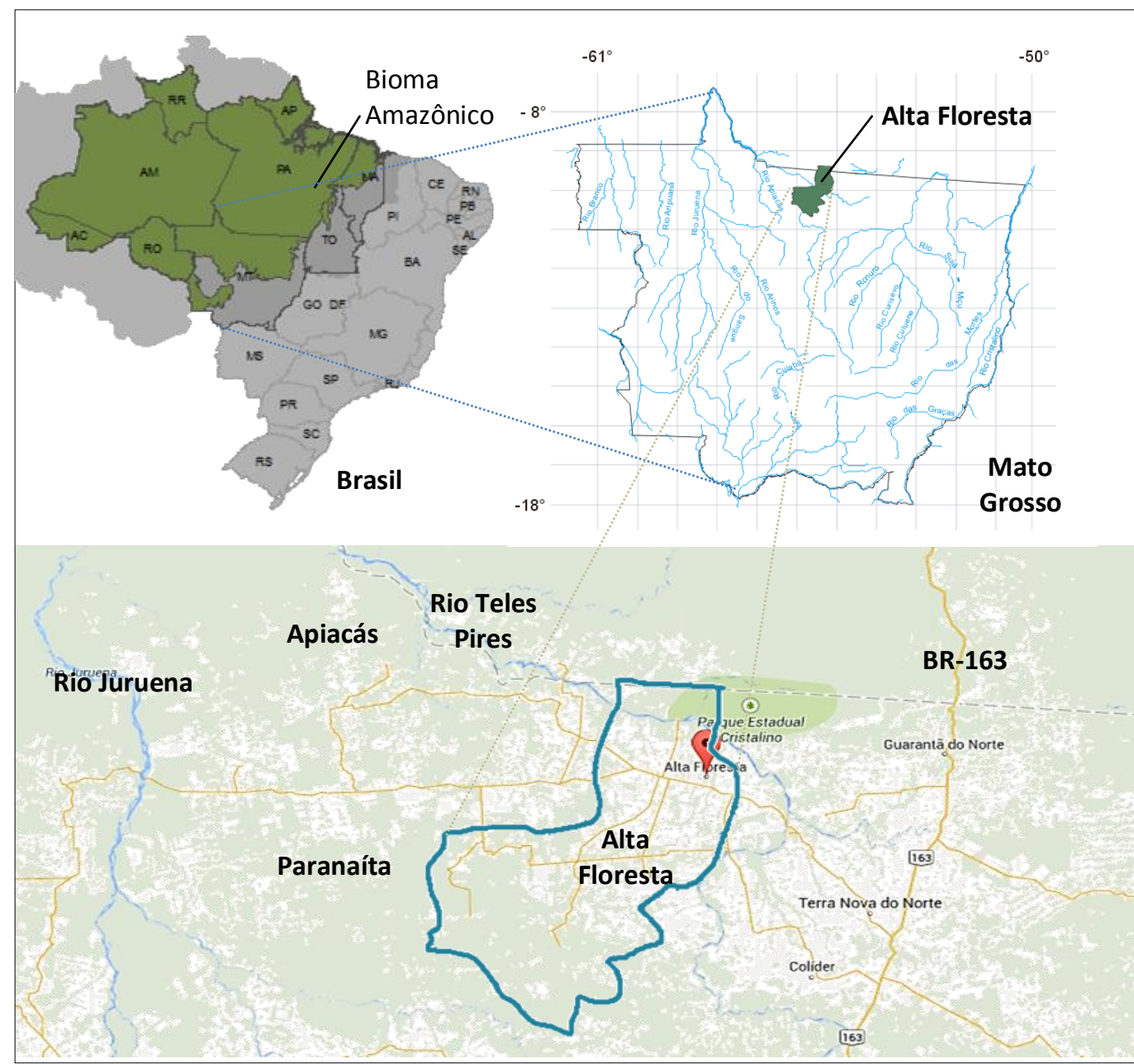

Figura 6 - Localização geográfica de Alta Floresta, MT: Bioma, bacias hidrográficas e rodovias. Fontes: IPAM (2014) e Google maps (2014) (com adaptações).

O compromisso assumido pela empresa foi de repassar os lotes aos agricultores num prazo máximo de cinco anos e em conformidade com as normas estabelecidas pelo INCRA (Instituto Nacional de Colonização e Reforma Agrária) (JOANONI NETO, 2007). Coube a ela 
todo o processo de levantamento, demarcação e ocupação da terra, a abertura de estradas vicinais, o planejamento da área urbana, a implantação das obras de infraestrutura e o fornecimento dos serviços de saúde e educação (JEPSON, 2006; MIRANDA, 1990). Em troca, a colonizadora lucrava com a venda dos lotes e, em alguns casos, com a retirada da madeira (JEPSON, 2006).

\subsubsection{O projeto Alta Floresta: do "ideal" ao concreto}

Segundo Guimarães Neto (2002), o projeto de ocupação agrícola de Alta Floresta foi criado no imaginário de seu idealizador, o proprietário da empresa INDECO, Ariosto da Riva, um paulista, antigo corretor de imóveis de um príncipe polonês que morava em São Paulo e possuía fazendas no interior do Estado do Mato Grosso do Sul (SCHWANTES, 1989). Esse colonizador tinha em seu histórico a criação da cidade Naviraí, no Mato Grosso do Sul. Além disso, havia sido responsável pela demarcação de uma área de mais de um milhão de hectares na fazenda Suiá-Missú, situada na região Nordeste do Estado de Mato Grosso (GUIMARÃES NETO, 2002), em terras do povo indígena Xavante ${ }^{51}$.

O objetivo de Ariosto da Riva era implantar, nas terras consideradas mais produtivas de Alta Floresta, um virtuoso e "moderno" projeto de colonização, que não havia sido possível efetivar em suas investidas anteriores (JOANONI NETO, 2007).

Para Guimarães Neto (2002), o projeto de Ariosto da Riva foi construído sobre uma visão mítica da Amazônia, fundamentada por ideias como a da "terra da riqueza". Sob esta ótica se colocaram em marcha - repetindo os ideais de Getúlio Vargas, da "marcha para o Oeste", na década de 1930 - verdadeiros guerreiros, vindos do Sul do Brasil "de machado e foice nas mãos, prontos para enfrentar o perigo e a 'natureza selvagem'” (p. 52). Estes homens e mulheres objetivavam conquistar a nova terra e sua independência econômica.

Uma vez na região, as famílias enfrentaram grandes adversidades. Entre elas, os perigos proporcionados pela abertura da floresta, a malária e o endividamento dos agricultores em decorrência dos maus resultados da produção ou de sua perda, ainda nas lavouras, devido às dificuldades de estocagem e escoamento (MIRANDA, 1990). Além disso, os agricultores tiveram de superar as deficiências na infraestrutura prometida, a inoperância dos serviços e o isolamento no interior da mata, entre outros fatores igualmente graves, que contribuíram para o abandono de lotes e a migração de muitos para a atividade

\footnotetext{
${ }^{51}$ Essas terras foram retomadas, em partes, em junho de 2012, pelo povo Xavante. O processo ocorreu sob decisão judicial e em meio a grandes conflitos com produtores rurais instalados na região há mais de 20 anos e usados como "frente de batalha" por latifundiários da região.
} 
garimpeira ou, em outros casos, para novas zonas de ocupação recente da Amazônia (JOANONI NETO, 2007).

Os migrantes foram atraídos pela propaganda, a principal estratégia usada pela INDECO para instigar a compra das terras. A empresa possuía escritórios de venda em cidades do Oeste e Norte do Paraná, onde corretores atuavam convencendo os camponeses das vantagens da migração para a Amazônia: as facilidades de aquisição de uma propriedade na Amazônia, o baixo preço da terra, a "alta" fertilidade do solo ${ }^{52}$ e as boas condições climáticas para a produção de café.

Os corretores da INDECO realizavam visitas e reuniões, apresentando slides e distribuindo panfletos de uma extraordinária plantação de café, das vastas terras férteis e baratas e de alguma infraestrutura já existente no local (JOANONI NETO, 2007). A Amazônia era exibida como a solução dos problemas das famílias do Paraná: risco de perda autonomia econômica, êxodo rural e desemprego (LE BORGNE-DAVID, 1998). Além disso, outro atrativo que mexia com a expectativa dos agricultores era a possibilidade de aumentar o tamanho da propriedade em três ou quatro vezes, em razão do baixo preço das terras (MOREIRA, 2014).

Grosso modo, o projeto da INDECO se destinava a pequenos produtores do interior do Paraná. Entre as décadas de 1940 e 1960, aquela região havia recebido um importante contingente de migrantes oriundos de estados do Nordeste, atraídos para servir de mão-deobra nas fazendas de café. A renda do trabalho permitiu-lhes adquirir propriedades de 5 a 50 hectares e formar seus próprios cafezais (AUBERTIN, 1990; RIBEIRO; SILVA, 2010). Esses pequenos proprietários interessavam à empresa por possuírem certa reserva de capital, suficiente para quitar a primeira parcela da nova propriedade. Além disso, interessava a sua experiência com a produção de café e a formação de uma fronteira agrícola (AUBERTIN, 1990).

\footnotetext{
${ }^{52}$ O mito da alta fertilidade do solo amazônico foi produzido ainda no início do século XIX a partir dos discursos do naturalista e explorador alemão Alexander von Humboldt. No século XX, o mito ganhou força com as declarações do presidente americano Theodore Roosevelt, que conheceu a floresta em uma expedição científica realizada entre 1913 e 1914. Eles disseminaram a ideia de que a Amazônia seria a "terra da superabundância" e o "celeiro do mundo". Imaginou-se, a partir disso, que a exuberância da floresta era sustentada por um solo igualmente fértil. No entanto, o tempo e o volume de prejuízos gerados pela conversão de solos pobres da Amazônia em terras agrícolas mostraram que, na verdade, a maior parte dos solos é rasa, mal estruturada, pobre e sobrevive à custa dos nutrientes que recebe da floresta (LOUREIRO, 2002). No outro extremo, disseminou-se que o mito contrário, de que os solos amazônicos de tão pobres não sustentariam qualquer atividade que não a preservação da floresta. Esta posição extremada vem sofrendo adequações recentes. $\mathrm{O}$ avanço da fronteira agrícola mostrou que existem extensas faixas de solos aptas e lucrativas para a agricultura (SILVA, 2009). Além disso, os projetos recentes mostram que os solos são passíveis de recuperação e reflorestamento.
} 
Entre as principais razões que levavam a trocar o Estado do Paraná pela Amazônia esteve a grande geada "negra", que havia dizimado a maior parte das lavouras de café, no ano de 1975. Além da perda da produção, este fenômeno acabara contribuindo para a transformação dos cafezais em lavouras de soja. Nestas circunstâncias, a aquisição de terras na Amazônia aparecia como uma alternativa diante do risco do êxodo rural, desemprego e empobrecimento.

O café foi eleito para ser o carro-chefe da economia da região de Alta Floresta. Esta opção foi determinada por uma política federal de orientação da produção, via créditos e incentivos fiscais (RIBEIRO, 2001). Aos agricultores interessados nas terras, a INDECO garantia a qualidade do solo e as adequadas condições climáticas a partir de resultados obtidos na fazenda experimental Caiabi, localizada em Alta Floresta (SELUCHINESK, 2008).

A primeira viagem dos prováveis compradores era financiada pela empresa (JOANONI NETO, 2007). O chefe da família viajava de avião para, do alto, escolher sua futura propriedade. No retorno para o Paraná, organizava a transferência da família. A viagem de caminhão, do Sul do país ao Norte de Mato Grosso, percorrendo cerca de 2.000 km, durava vários dias. Grande parte das estradas não era asfaltada e a travessia de rios, como o Teles Pires, era realizada sobre balsas.

Os agricultores chegavam à região com o desejo de, ali, construir um futuro melhor para os filhos. O futuro, neste sentido, traduzia-se em melhores condições financeiras e mais estudos. Esta aspiração era correspondida pelas promessas da empresa colonizadora de construir uma escola em cada núcleo agrícola ${ }^{53}$. Nestes núcleos seria possível encontrar ajuda comunitária, compartilhar experiências e conservar a cultura paranaense, um dos desejos da maioria dos migrantes.

As famílias eram constituídas por casais com um a três filhos. A maioria dos pais tinha entre 35 e 50 anos de idade e possuía algum nível de escolaridade. Entretanto, apesar da capacidade de leitura, os migrantes tinham pouco ou quase nenhum conhecimento sobre as condições ambientais da nova região. Faltava-Ihes, nestes termos, a experiência para lidar com o clima, o solo e as características pluviométricas, importantes para a agricultura. Ademais, a ausência de conhecimentos sobre as características da floresta amazônica

\footnotetext{
${ }^{53} \mathrm{O}$ projeto de colonização foi organizado em núcleos agrícolas. A cada quatro quilômetros foram construídos uma escola e uma Igreja. Depois de alguns anos, a maioria desses núcleos também recebeu um campo de futebol e um salão de festas. O objetivo desta organização era possibilitar a reunião das famílias e o desenvolvimento de ações solidárias que ajudassem a minimizar 0 sofrimento e as dificuldades imediatas. As aulas, nas escolas, eram ministradas por filhos de agricultores com formação de ensino fundamental (até $8^{\mathrm{a}}$ série) e médio ( $2^{\circ}$ grau). Depois do ano 2000, a maioria dessas escolas foi fechada e os filhos dos agricultores passaram a estudar na zona urbana.
} 
prejudicava a prevenção contra mosquitos transmissores da malária e da leishmaniose, entre outras doenças que poderiam se disseminar entre a população.

$\mathrm{Na}$ chegada à Alta Floresta, um funcionário da INDECO conduzia a família à sua propriedade. Na descrição de Guimarães Neto (2002, p. 73), o caminhão adentrava 30 ou $40 \mathrm{~km}$ de picadões em meio à mata fechada. No lugar de destino, "parava o caminhão, desciam todos, amarravam os animais nas árvores, desciam os badulaques, faziam barraca com o encerado, punham a família em baixo, e o caminhão voltava". Os primeiros dias eram de descoberta: as grandes árvores, os animais silvestres, o calor, os mosquitos. A primeira tarefa era a improvisação de uma moradia. Em poucas semanas, o acampamento de lonapreta era substituído por uma casa de madeira. Entretanto, essas moradias também eram precárias, muitas vezes sem água potável, banheiros e proteção contra a entrada de mosquitos (figura 7). Os alimentos eram escassos, principalmente para as crianças, a quem faltava o leite de vaca (JOANONI NETO, 2007).

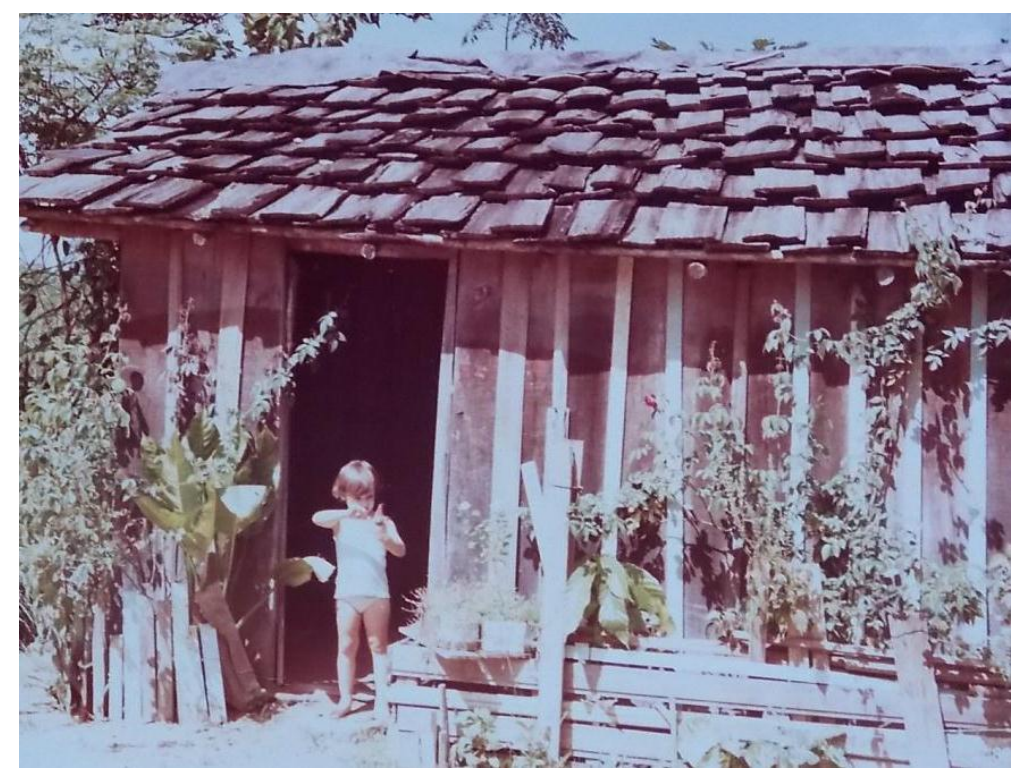

Figura 7 - As características das primeiras casas da zona rural de Alta Floresta. Foto: Esmeralda.

Concluída a construção da moradia, iniciava-se a abertura da área e o preparo da terra para o plantio. Em poucas semanas, os desmatamentos se desdobravam sobre vastas áreas. O trabalho era realizado em parceria com os vizinhos. Segundo Lessa (1991, p. 45), "duplas de tratores arrastavam correntes de navios, derrubando as árvores". Os restos florestais eram eliminados com fogo. As primeiras queimadas originavam gigantescos incêndios florestais, que se estendiam por vários dias (SCHWANTES, 1989). Quase nada da madeira do desmatamento era aproveitada, a não ser para a construção local (SELUCHINESK, 2008).

Segundo Guimarães Neto (2002), a INDECO cumpriu o compromisso de construir as estradas vicinais, demarcar as propriedades e implantar um núcleo urbano que contasse 
com uma infraestrutura mínima: escolas, atendimento hospitalar, entre outros (figura 8). Todos esses empreendimentos pertenciam inicialmente à empresa que, pouco a pouco, os terceirizou ou devolveu a sua gestão ao Estado (MIRANDA, 1990; ROCHA, 2008).
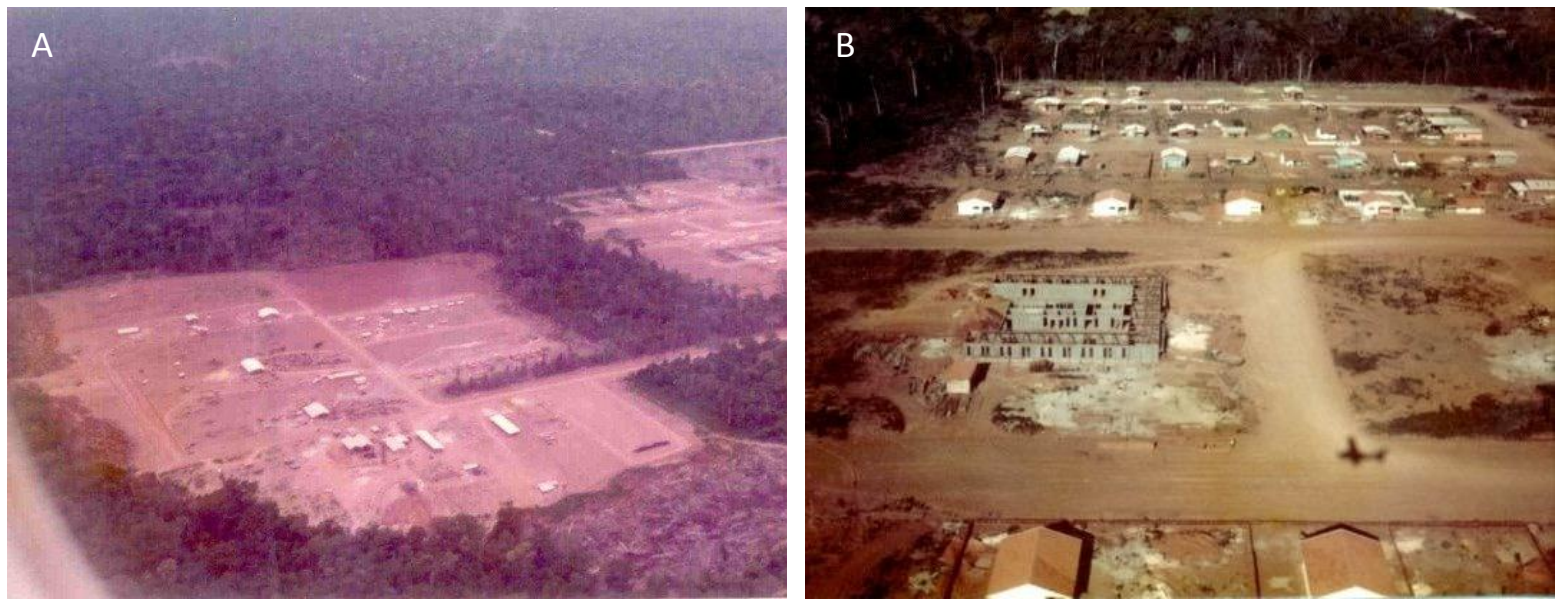

Figura 8 - A cidade de Alta Floresta em 1976 (A) e em 1978 (B). Foto: Carlos Girardi.

A descoberta de ouro na região, depois de 1978, a população local aumentou de 1.200 habitantes para 23.000 habitantes, de 1976 a 1980 (SCHAEFER, 1985). Em 1991, eram 66.926 pessoas, contadas pelo IBGE (Instituto Brasileiro de Geografia e Estatística) (2014a) (Gráfico 2).

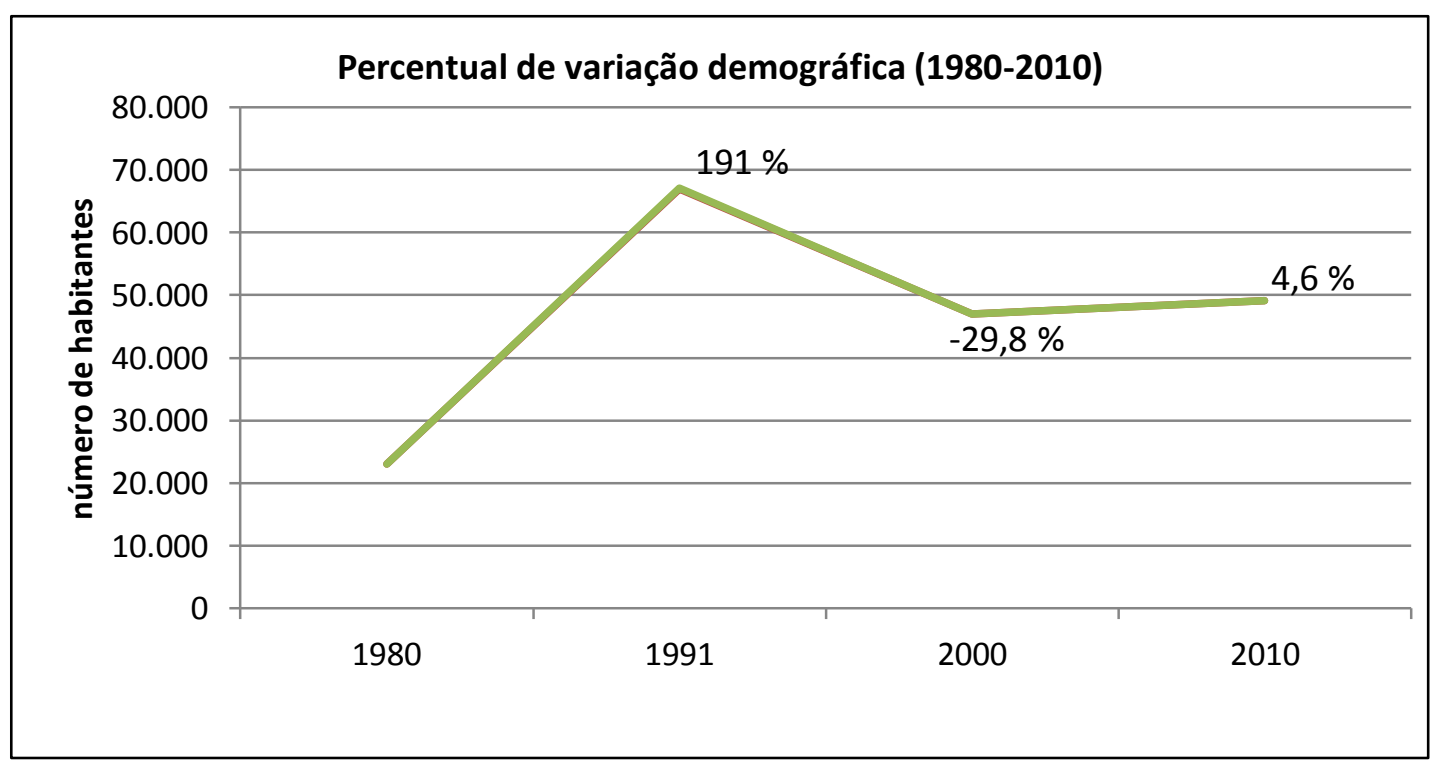

Gráfico 2 - Variação da população de Alta Floresta (1990 a 2010). Fonte: IBGE (2014a).

A chegada de um grande contingente de garimpeiros produziu conflitos, sobretudo com os interesses da INDECO. Os garimpos ameaçavam o cumprimento das etapas previstas no projeto, colocando em risco os recursos oficiais e os incentivos fiscais, "bem como o controle do estoque da mão-de-obra disponível" (RIBEIRO, 2001, p. 4). Três 
aspectos, em particular, se tornaram preocupantes para a empresa: (i) o enorme fluxo populacional, (ii) o abandono da produção ou a venda de terras e (iii) a interrupção da migração de agricultores para a região e, portanto, da venda de novas terras (BONINI; PESSOA; SEABRA JUNIOR, 2013).

Uma das medidas tomadas pelo INDECO foi a reespacialização dos garimpeiros, removendo-os para áreas distantes do município. A resistência dos garimpeiros desencadeou uma operação repressiva e violenta, um evento conhecido regionalmente como "taca". O episódio foi denunciado pela Comissão Pastoral da Terra (CPT, 1979) como um grande massacre, que teria resultado na morte de pelo menos 300 pessoas (RIBEIRO, 2001).

O assentamento das famílias não foi realizado sem conflitos. Há registros de um forte controle e domínio social, exercido pela INDECO, que excluía, não somente especuladores, mas, sobretudo, agricultores sem terra e garimpeiros (GUIMARÃES NETO, 2002; JOANONI NETO, 2007). Um discurso registrado no Diário do Congresso Nacional (BRASIL, 1979, p. 9.576), faz referência ao domínio político exercido pelas colonizadoras instaladas no Norte do Estado de Mato Grosso, com menção especial à INDECO. O dono da colonizadora, Ariosto da Riva, foi então acusado de estabelecer "uma espécie de governo paralelo", por meio do qual teria exercido "uma inconcebível tutela, não levando em conta a consciência politica de cada um". Além disso, o seu "coronelismo político-econômico" teria sido usado para ameaçar de morte aqueles que faziam "denúncias sobre a escravidão branca e outros abusos" exercidos pela empresa, principalmente sobre as populações pobres.

Além deste, outros conflitos marcaram a época. O contingente populacional sem recursos para adquirir terras foi impedido de adentrar na área do projeto. Segundo Guimarães Neto (2003), o rio Teles Pires, que à época era atravessado por meio de uma balsa, era usado como ponto de seleção daqueles considerados aptos a adquirir propriedades no projeto de Alta Floresta. O público remanescente foi assentado, em um período de dois a cinco anos, em uma área adjacente ao projeto da INDECO, de aproximadamente 240 mil hectares, criada pelo INCRA. Essa área configura atualmente o município de Carlinda (MIRANDA, 1990).

Em última instância, mesmo sendo destinado à pequena produção, menos de $50 \%$ das terras do território municipal de Alta Floresta foram revertidas à pequena propriedade (100 a 300 hectares). Inúmeras deficiências na infraestrutura prometida, a ausência de órgãos governamentais, as dificuldades de comercialização da produção, o isolamento e as doenças, acabaram por provocar a venda das pequenas propriedades, produzindo um rápido processo de urbanização precária e reconcentração da terra (JOANONI NETO, 2007). 


\subsection{A rápida urbanização}

Alta Floresta é um dos municípios mais urbanos do Norte mato-grossense. Apenas 13\% de seus 49.761 habitantes residem no meio rural (IBGE, 2014a). A cidade abriga, principalmente, as novas elites locais, formadas a partir da expansão da pecuária extensiva, e os trabalhadores que migraram do campo ou aqueles que permaneceram na região, ao término dos garimpos. Ela também concentra algumas ONGs socioambientalistas, como o ICV (Instituto Centro de Vida) e o IOV (Instituto Ouro Verde), além de um Campus da UNEMAT (Universidade do Estado de Mato Grosso) e escritórios regionais do IBAMA (Instituto Brasileiro do Meio Ambiente e dos Recursos Naturais Renováveis), da SEMA (Secretaria de Estado do Meio Ambiente) e da SES (Secretaria de Estado de Saúde).

O fenômeno da urbanização era destacado no próprio projeto agrícola. Na visão do colonizador, com exceção da educação, a cidade devia concentrar todos os demais serviços e demandas das famílias rurais (JOANONI NETO, 2007). A rede urbana de Alta Floresta foi inspirada na filosofia do urbanismo rural do INCRA e, paradoxalmente, se reproduziu, segundo Becker (1985), com mais sucesso do que nos projetos de ocupação agrícola coordenados pelo Estado. No início, o centro urbano servia de referência para o controle da ocupação dos 364 pequenos núcleos e comunidades rurais, instalados a cada três quilômetros. Com o processo de reconcentração de terras, promovido, entre outros fatores, pelo crescimento da pecuária extensiva, a partir da década de 1990, muitos desses núcleos acabaram sendo desestruturados. As escolas foram fechadas e os filhos dos pequenos agricultores foram estudar na cidade (PRETI, 1981; ROCHA, 2008).

O encerramento da atividade garimpeira, no início dos anos 1990, produziu uma importante concentração de mão-de-obra na periferia da cidade (RIBEIRO, 2001). Eram trabalhadores sem emprego fixo, que prestavam serviços principalmente em fazendas ou para as serrarias, onde trabalhavam no desmatamento e no corte e na retirada da madeira da mata.

Em síntese, vale ressaltar a importância que a cidade de Alta Floresta tem para a região em que se insere. Ela se configura, atualmente, no centro econômico-administrativo de 16 municípios $^{54}$ que compõem o território ${ }^{55}$ do Norte de Mato Grosso. Este conjunto de

\footnotetext{
${ }^{54}$ Alta Floresta, Apiacás, Carlinda, Colíder, Guarantã do Norte, Marcelândia, Matupá, Nova Bandeirantes, Nova Canaã do Norte, Nova Guarita, Nova Monte verde, Novo Mundo, Paranaíta, Peixoto de Azevedo, Terra Nova do Norte e Nova Santa Helena.

${ }^{55}$ Sob o ponto de vista do Ministério do Desenvolvimento Agrário, este território é abordado como "Portal da Amazônia". Ele pertence ao universo dos 120 Territórios da Cidadania. Trata-se de um programa federal voltado para regiões onde os investimentos públicos e privados não têm sido suficientes para garantir o atendimento das necessidades básicas da população. O objetivo é avançar na redução das desigualdades sociais e regionais, tendo como base uma estratégia de
} 
municípios tem sido recentemente integrado por meio de um conjunto de políticas de promoção do desenvolvimento territorial, desenvolvido pelo Ministério do Desenvolvimento Agrário (MDA) (BRASIL, 2007a).

Outro fator importante quando se trata do crescimento do índice de urbanização de Alta Floresta (superior a $80 \%$ ) é o fenômeno antropológico que o processo encerra. Para Becker (2005a), numa fronteira agrícola como a de Alta Floresta, o crescimento da cidade está relacionado à difusão dos valores urbanos. Os hábitos e comportamentos são, então, guiados pelo consumo e não mais pela produção. O que dissemina esta mudança, segundo a autora, são as redes de telecomunicações e a mobilidade de trabalho (rural-urbano).

\subsection{Indicadores socioeconômicos}

Os indicadores socioeconômicos do município, relativos à desigualdade e pobreza, modificaram-se de forma significativa nas últimas décadas (Gráfico 3a). De acordo com a classificação do Programa das Nações Unidas para o Desenvolvimento (PNUD), o índice de Gini $^{56}$, um indicador que mede o grau de desigualdade em função da renda domiciliar per capita, variou de 0,55 em 1991, para 0,48 em 2010 (PNUD, 2013). Quanto mais distante de 1, menor a desigualdade na distribuição da renda.

Também houve uma importante redução do percentual da população que vive em situação de pobreza ou pobreza extrema (Gráfico 3b) (PNUD, 2013). Além da evolução da renda (Gráfico 3c), a redução desses índices é explicada pelas mudanças socioeconômicas provocadas pelo "Bolsa Família" ${ }^{57}$, programa nacional de transferência de renda criado em 2004. Adicionalmente, tem grande importância socioeconômica as aposentadorias de agricultores familiares ${ }^{58}$. Tais programas cobrem em torno de $13 \%{ }^{59}$ da população local (BRASIL, 2010; IBGE, 2014b).

desenvolvimento territorial, alicerçada na participação social e na integração de ações governamentais (BRASIL, 2007a).

${ }^{56} \mathrm{O}$ Índice de Gini é uma medida de desigualdade de distribuição de renda. Ele consiste em um número entre 0 e 1, onde 0 corresponde à completa igualdade de renda (todos têm a mesma renda) e 1 corresponde à completa desigualdade (uma pessoa tem toda a renda e as demais não tem nenhuma renda). Segundo o Instituto Brasileiro de Geografia e Estatística (2013), atualmente, o índice de Gini nacional é de 0,498.

57 "Bolsa Família" é um programa de transferência de renda criado durante o Governo de Luís Inácio Lula da Silva (2003). Ele tem como objetivo principal combater a fome e a pobreza e promover a segurança alimentar e nutricional, bem como a emancipação dos grupos familiares mais vulneráveis socialmente. Destina-se às famílias em situação de pobreza e extrema pobreza, com renda per capita de até $\mathrm{R} \$ 154$ mensais e condiciona a transferência do benefício financeiro ao acesso das crianças na escola.

${ }^{58}$ Garantido pela Lei n. 8.213/91.

${ }^{59}$ São 3.460 famílias beneficiárias do Programa Bolsa Família (BRASIL, 2010) e 3.199 pessoas com idade acima de 55 anos, aposentadas (IBGE, 2014b). 
Alta Floresta é uma cidade jovem, cerca de $65 \%$ da população é considerada economicamente ativa. A população idosa, acima de 65 anos, representa apenas 2,9\% do todo, aproximadamente 2.800 pessoas (IBGE, 2014a) (Gráfico 3d).
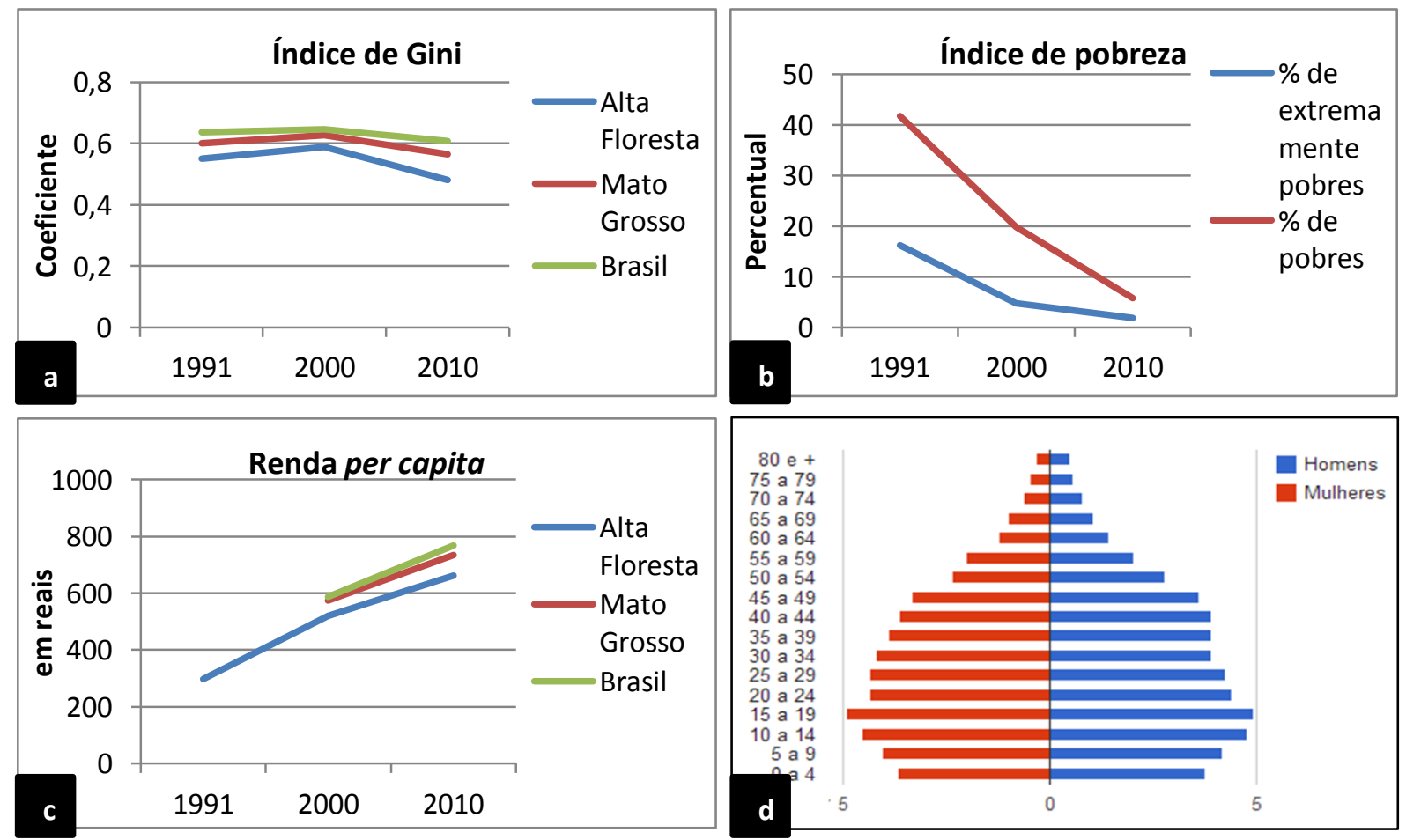

Gráfico 3 - a) Índice de Gini - comparação entre Alta Floresta, Mato Grosso e Brasil. b) Índice de pobreza em Alta Floresta. c) Renda per capita - comparação entre Alta Floresta, Mato Grosso e Brasil. d) Pirâmide etária em 2013. Fonte: PNUD (2013).

\section{Conclusão}

Este capítulo apresentou alguns elementos-chave para compreender o campo em que se insere a pesquisa. O objetivo foi alicerçar a análise dos dados. Neste sentido, vale destacar dois pontos em particular. O primeiro diz respeito ao contexto em que se ocupou a região amazônica que atualmente configura a fronteira de Alta Floresta. Tratava-se de um momento ímpar, de transformação dos modos de produção agrícola, orientado pelo governo brasileiro. Esta dinâmica se alastrou por vastas regiões agrícolas, sobretudo do Sul do país, disseminando o consumo de sementes híbridas, patenteadas por empresas multinacionais, e outros insumos, como fertilizantes e agrotóxicos, além da mecanização dos serviços.

As consequências deste processo foram, entre outros fatores, a transferência de centenas de pequenos produtores para a Amazônia. No novo espaço, eles disseminaram as práticas "modernas" de produção, aprendidas em sua região de origem. As consequências foram, no que concerne ao segundo ponto de destaque deste capítulo, o enfrentamento de uma série de riscos impostos pela floresta, como a formação das áreas de cultivo, as 
doenças, o endividamento e perda da terra. Ademais, o modelo de ocupação do espaço e de produção agrícola esteve relacionado ao crescente aumento da desigualdade social. Problema que vem sendo minimizado recentemente pelo acesso a políticas sociais de transferência de renda e as aposentadorias de produtores rurais. 


\section{Capítulo 5. DELINEAMENTO DO ESTUDO: A RELAÇÃO ENTRE A DEGRADAÇÃO AMBIENTAL E A SAÚDE NA FRONTEIRA}

\section{Introdução}

Depois de oferecer o referencial teórico sobre meio ambiente, risco, processo saúdedoença e fronteira agrícola, bem como, a caracterização da área de estudo, o capítulo atual aborda a problemática do estudo. Como desenvolver um estudo que articula fenômenos como a degradação ambiental e a saúde? Como inserir, nesta perspectiva, um enfoque temporal, que considera a fronteira como um movimento? Que elementos do "ciclo de vida" da fronteira ajudam a desenvolver esta interpretação?

O capítulo é esclarecedor em que concerne a responder perguntas como estas. Para tanto, ele mostra as abordagens adotadas na pesquisa e define as noções que fundamentam o objeto e a construção da análise. Adicionalmente, são apresentados alguns elementos do percurso pessoal e profissional desta autora, os quais subsidiaram a construção do objeto e a delimitação da pesquisa.

\subsection{O corpo teórico da pesquisa}

O objeto da pesquisa é a interface entre a degradação ambiental e a saúde. De forma mais esclarecedora, podemos definir o estudo como um esforço para compreender a relação entre a degradação ambiental e a saúde coletiva ao longo da ocupação da fronteira agrícola de Alta Floresta, Norte do Estado de Mato Grosso.

A base teórica que fundamenta a análise do objeto advém da área da saúde ambiental. Trata-se de um campo emergente, que se sustenta nos corpos teóricos das ciências ambientais e da área da saúde coletiva e tem, como principal perspectiva, a incorporação da questão ambiental na investigação do perfil epidemiológico e territórios em particular.

Neste contexto, apreendemos a noção de processo saúde-doença, não como a simples ausência de doença, mas como um fenômeno que diminui as capacidades e a condição individual de realizar anseios e satisfações da vida (ALMEIDA FILHO, 2011; PORTO, 2007). O julgamento dessa redução de capacidades, que define a presença ou a ausência de saúde, depende, neste estudo, da percepção social. Nesta perspectiva, a saúde é tratada como uma ideia. Ela significa aquilo que percebem, pensam e/ou sentem as pessoas que adoecem. Esta percepção é construída a partir dos saberes, das crenças, dos 
costumes, dos hábitos e das opiniões dos indivíduos e dos grupos sociais que eles integram (MINAYO, 2006). Ela também é influenciada pelo ponto de vista médico (LAPLANTINE, 1991).

Como esta noção de saúde é abordada neste estudo? Em primeiro lugar, é importante destacar que, embora estejamos falando de uma conceituação individual da saúde (como fenômeno que diminui as capacidades e a condição individual de realizar anseios e satisfações da vida), esta pesquisa compreende a saúde como um fenômeno social, coletivo. Isto porque, o que interessa é a manifestação da saúde no conjunto populacional, no curso do tempo. Como se comportou, ao longo do avanço da ocupação da fronteira agrícola, a saúde coletiva? Esta é, por exemplo, uma das perguntas que se procura responder.

\subsection{O desenho da pesquisa}

As noções e categorias analíticas apresentadas, até aqui, fundamentaram o esforço de pesquisa, que teve como objetivo compreender a relação entre a degradação ambiental e a saúde coletiva no contexto de uma fronteira agrícola.

Nesta perspectiva, orientaram a pesquisa, os seguintes objetivos específicos:

(i) Conhecer as etapas do avanço da ocupação agrícola da fronteira de Alta Floresta;

(ii) Identificar e qualificar as formas de degradação do meio ambiente ao longo da ocupação;

(iii) Compreender a relação entre a degradação ambiental e a emergência das doenças.

As perguntas que nortearam a pesquisa foram: Como a degradação ambiental afetou a saúde da população local, no curso do avanço da fronteira agrícola? Sob o ponto de vista da saúde pública, quais são as tendências atuais da fronteira agrícola?

Para conduzir o estudo, a partir destas perguntas, foram elaboradas duas hipóteses. A primeira é que, no curso do avanço da fronteira agrícola de Alta Floresta, a emergência das doenças de maior importância em termos de saúde pública foi determinada, entre outros fatores, pela degradação e a contaminação do meio ambiente.

A segunda hipótese é que, em termos de saúde pública, a fronteira de Alta Floresta está integrada ao território nacional, uma vez que o perfil epidemiológico converge para a tendência observada no restante no país. Neste contexto, contudo, a degradação ambiental, provocada pela ocupação agrícola, não perde sua importância. Ao contrário, ela se mantém como o principal determinante da emergência e manutenção das doenças crônicas. 


\subsection{A construção do objeto}

A pesquisa se situa no contexto de nosso trabalho na fronteira agrícola de Alta Floresta. Desde 2006, vimos desenvolvendo projetos na área da saúde ambiental. Uma das experiências mais significativas foi conduzida com a comunidade ${ }^{60}$ de um assentamento de reforma agrária, entre os anos de 2009 e 2010. Tratava-se de um projeto de pesquisa-ação (THIOLLENT, 2005), ancorado nas perspectivas da área da saúde ambiental e nas técnicas oferecidas pela ecossaúde. Na ocasião, aplicamos cinco oficinas participativas que visavam experimentar o potencial desta técnica nas pesquisas de saúde ambiental. Aquela comunidade apresentava altas taxas de prevalência de verminoses e as oficinas, associadas à pesquisa epidemiológica e parasitológica, permitiram ampliar a compreensão das causas ambientais deste problema. Além disso, a experiência nos deixou convencidos que os métodos participativos, se rigorosamente definidos a aplicados, ampliam a compreensão de problemáticas ditas complexas, como a relação meio ambiente e saúde.

Em 2011, durante o primeiro ano do curso de doutorado, voltamos a Alta Floresta e organizamos uma oficina participativa com onze profissionais da saúde ou afins. Do trabalho, resultou o esboço de uma cronologia da evolução da saúde e dos problemas ambientais da região. Este esboço nos permitiu perceber dois elementos importantes: (i) uma possível associação entre as etapas do ciclo de vida da fronteira (agricultura familiar, garimpo, madeira e pecuária extensiva) e os problemas ambientais e (ii) uma tendente transição de doenças, de infecciosas para crônico-degenerativas, acompanhando o avanço da ocupação agrícola. Tais elementos nos apoiaram na construção das hipóteses e dos procedimentos metodológicos adotados na pesquisa.

Mais adiante, durante as disciplinas do doutorado, descobrimos uma série de abordagens e referências teóricas no âmbito da questão ambiental e do desenvolvimento sustentável que nos ajudaram a construir o objeto de pesquisa. Entre as nossas descobertas teóricas mais significativas, neste sentido, podemos citar: (i) a noção de meio ambiente, como um produto da sociedade contemporânea (HANNIGAN, 1995; LATOUR, 2005), (ii) a noção de risco como construção e representação social (BECK, 2010; GIDDENS, 1991; HANNIGAN, 1995; MOSCOVICl, 2000) e (iii) a inserção da saúde ambiental no campo do desenvolvimento sustentável (CABANES; ROUSSEL, 2010; MINAYO; CARVALHO, 2002). Tais descobertas acabaram dando um novo direcionamento à pesquisa, sobretudo no que diz respeito à incorporação da noção de risco.

${ }^{60}$ Comunidade Vila Rural I, com 176 famílias, implantada pelo INTERMAT (Instituto de Terras do Estado de Mato Grosso), em 2003. 
Em 2013, durante o estágio "sanduíche" do doutorado, realizado no CIRAD (Centre de coopération internationale en recherche agronomique pour le développement), em Montpellier, na França ${ }^{61}$, tivemos a oportunidade de discutir o projeto da tese com pesquisadores de diversas áreas, muito deles, dedicados ao estudo de fronteiras agrícolas amazônicas. Estas discussões, e as leituras que se seguiram, nos ajudaram a melhor compreender a dinâmica da fronteira agrícola, fato que afinou a demarcação do quadro teórico.

Talvez seja pertinente lembrar que a fronteira agrícola faz parte de nosso percurso de vida. Nossa trajetória integra a migração do Rio Grande do Sul para o Mato Grosso ${ }^{62}$, ainda no início da infância, e, em decorrência disso, a imersão nos problemas inerentes ao avanço da fronteira. Associam-se a esta experiência, o acompanhamento da trajetória do avanço da monocultura e do uso de agrotóxicos, bem como a evolução do perfil epidemiológico.

\section{Conclusão}

Este capítulo é substancial para a compreensão do esforço que empreendemos para compreender a relação meio ambiente e saúde na fronteira. Ele define, com mais clareza, o objeto, os objetivos e as hipóteses. Adicionalmente, trilha o caminho percorrido no processo de definição das categorias analíticas e das abordagens epistemológicas.

É importante lembrar que não se trata de um estudo que pretendeu comprovar, com base em dados estatísticos, o comportamento da saúde ambiental na fronteira. Diferentemente, este foi um esforço para apresentar pistas, baseadas na construção cognitiva de grupos sociais, sobre a relação entre a saúde coletiva e a degradação e contaminação ambiental, ao longo da evolução da fronteira agrícola de Alta floresta. Esta análise foi complementada com os resultados de uma série de estudos epidemiológicos e sociais realizados na fronteira agrícola de Alta Floresta e regiões adjacentes. Como executamos a coleta de dados? Como estes dados foram organizados e analisados? Como foram associados aos resultados preexistentes? Estas questões são respondidas no próximo capítulo, que trata da construção do método de pesquisa.

\footnotetext{
${ }^{61}$ Sob orientação do pesquisador Jean-François Tourrand, veterinário e conhecedor da dinâmica da pecuária na Amazônia.

${ }^{62}$ Para o município de Nova Xavantina, região Nordeste de Mato Grosso.
} 


\section{Capítulo 6. MÉTODO}

\section{Introdução}

De posse do conhecimento do desenho da pesquisa, é possível, agora, descrever o método e as técnicas que viabilizam a sua operacionalização. O objetivo do capítulo é detalhar os fundamentos do método, bem como o passo-a-passo que conduziu as atividades de campo e a organização dos resultados. O capítulo faz, portanto, o elo entre a abordagem teórica, apresentada nos capítulos precedentes, e a seção seguinte, destinada à análise e discussão dos resultados e às conclusões finais do estudo.

A base teórica do método e as técnicas que se adotam para aplicá-lo foram oferecidos pela ecossaúde. Em termos de variáveis da pesquisa, foram priorizadas as informações relacionadas à noção de risco e saúde. Essas informações foram captadas por meio de uma técnica denomina "linha do tempo" (CHAMBERS, 1994; FARIA; FERREIRA NETO, 2006). Ela foi construída a partir do encontro de grupos de pessoas que participaram das fases de ocupação da fronteira de Alta floresta. Esse encontro e a forma com que a discussão foi conduzida são denominados "grupo focal" (KRUEGER, 1988).

Os resultados da pesquisa empírica foram agrupados por similaridade, organizados em diagramas e, para efeito de discussão, colocados em contraste com o conhecimento gerado por outros estudos científicos. Esta associação de informações permitiu validar as hipóteses do estudo.

\subsection{Um método centrado na abordagem ecossistêmica}

O quadro metodológico da pesquisa se sustenta nos princípios fundamentais da abordagem ecossistêmica: participação e interdisciplinaridade (LEBEL, 2003). Sob o ponto de vista metodológico, esses princípios nos permitiram: (i) sustentar o foco da pesquisa na relação entre o meio ambiente e a saúde, de modo a analisar como um se comporta em decorrência das modificações sofridas pelo outro (figura 9), (ii) analisar a evolução da fronteira para descobrir como cada etapa do avanço da ocupação agrícola na fronteira altera o meio ambiente e quais são as consequências dessas alterações à saúde coletiva (figura 10) e (iii) incluir os "pontos de vista"63 de grupos sociais que participaram da evolução da

\footnotetext{
${ }^{63}$ Esta opção se baseia na tendência recente de valorização dos saberes não-científicos no estudo das ameaças e riscos ambientais. Ela advém, conforme foi explicado em capítulos anteriores, da percepção de que a ciência, sozinha, não consegue elucidar a complexidade que envolve os problemas contemporâneos (LEFF, 2001).
} 
fronteira, como ponto de partida para apreender as ideias e interpretações ${ }^{64}$, sobre os riscos e a saúde.

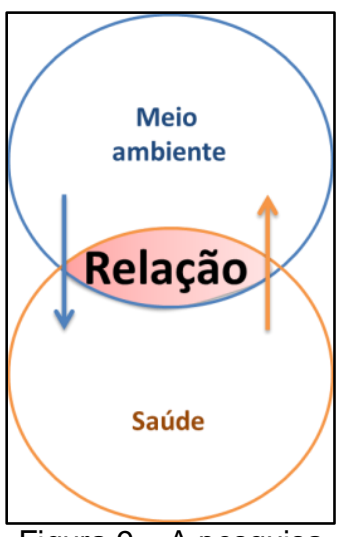

Figura 9 - A pesquisa foca a relação entre 0 meio ambiente e a saúde. Autoria própria.

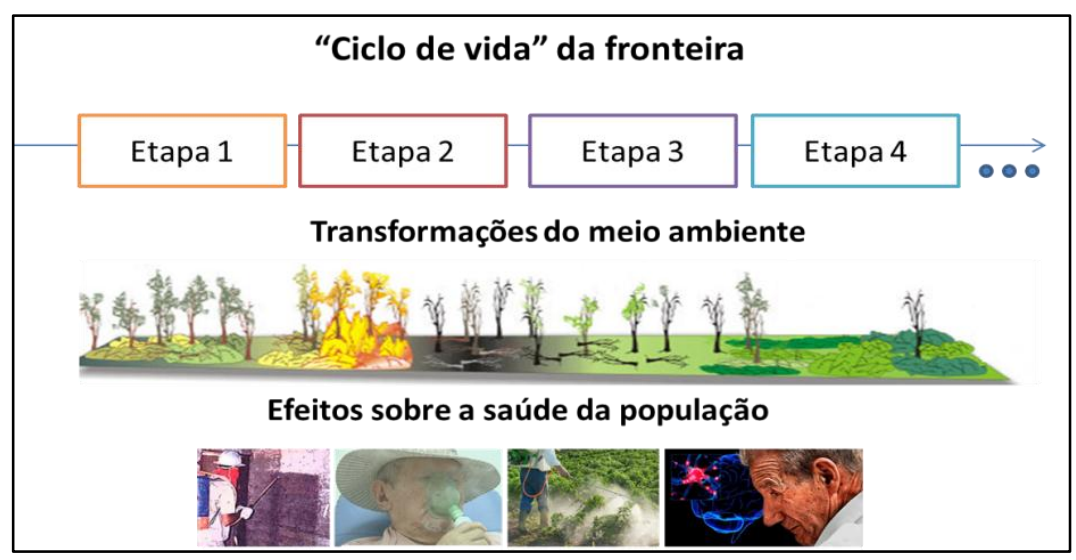

Figura 10 - Analisam-se as fases do ciclo de vida da fronteira, conectadas às transformações do meio ambiente e aos efeitos sobre a saúde da população. Autoria própria.

Estes três pontos configuram o cerne da abordagem que embasou a construção das técnicas usadas na pesquisa de campo. Essas técnicas integram: (i) entrevistas abertas, realizadas com pessoas-chaves, (ii) "grupos focais" 65 , aplicados a profissionais de saúde e pessoas que vivenciaram o avanço na fronteira agrícola em Alta Floresta, e (iii) "linhas do tempo" construídas durante os grupos focais com o objetivo de conhecer o comportamento da saúde coletiva ao longo das etapas do avanço da fronteira, bem como, a participação da degradação ambiental em sua definição.

A organização e a realização das atividades basearam-se em um dos fundamentos da ecossaúde: a participação. A participação é uma das estratégias da transdisciplinaridade, abordagem que subsidia a articulação do conhecimento. Ela permite apreender o problema de forma contextualizada ao dar voz aos membros da população que conhecem e vivenciam (LEBEL, 2003).

A organização das atividades de campo se baseou no instrumental metodológico oferecido pela AMESH (descrito no primeiro capítulo da tese): 1) diagnóstico de grupos; 2)

\footnotetext{
${ }^{64}$ Entendemos, neste sentido, que os "pontos de vista" são construídos socialmente, por meio da interação com a família, os amigos, a escola, entre outros, e são amplamente influenciados por informações científicas, capturadas a partir da veiculação midiática, leituras, conversas e outros meios de comunicação. Por esta razão, tratamos as ameaças como riscos, uma vez que elas são identificadas como construções sociais, influenciadas pela ciência. O mesmo vale para a saúde, a qual tratamos, nas atividades de campo, como ideia e, não, como uma noção científica. Afirmamos desta forma, que, assim como o risco, a saúde também é uma construção social.

${ }^{65}$ O grupo focal é uma técnica que faz alusão ao conceito de "esfera pública", desenvolvido por Jürgen Habermas ${ }^{65}$. A sua origem é anglo-saxônica e sua construção descende da década de 1940. Segundo Bauer e Gaskell (2002), existem três tradições distintas: a da terapia de grupo, que tem origem no Instituto Tavistock de Relações Humanas, na Grã-Bretanha, a da técnica da entrevista focalizada ${ }^{65}$, desenvolvida por Merton e Kendall (1984), e a da dinâmica de grupo da psicologia social, criada por Lewin (1958).
} 
coleta de narrativas; 3) elaboração de diagramas; 4) análise de variáveis endógenas e exógenas; 5) análise do sistema. As seções seguintes descrevem o percurso metodológico da pesquisa e justificam as escolhas do método e das técnicas.

\subsection{Os grupos focais: uma técnica para a coleta de dados}

Nos projetos fundamentados pela ecossaúde, a coleta de dados é desenvolvida por meio de oficinas participativas, as quais são moderadas por uma equipe interdisciplinar de pesquisa. A atividade permite aglutinar um grande volume de informações que é analisado por um conjunto diverso de pesquisadores, os quais cuidam, cada qual, dos dados sobre os quais têm propriedade (FORGET; LEBEL, 2001). Esta é uma característica das técnicas apresentadas pela ecossaúde que dificulta a sua execução em um trabalho de tese, por ser, este, um projeto executado individualmente.

Para driblar este problema, as oficinas participativas foram substituídas pela técnica denominada "grupo focal" (grupo de discussão). Trata-se de um método participativo que reúne seis a oito pessoas para realizar uma discussão informal, moderada por um único pesquisador (TRAD, 2009; WELLER, 2006).

Sob o ponto de vista metodológico, a posição que o grupo focal ocupa nas distintas formas de investigação varia de acordo com o objetivo da pesquisa. Em alguns casos, ele é usado para ajudar na formulação de questionários, em outros, é combinado com diferentes métodos qualitativos, como observação participante ou em entrevistas semiestruturadas (LERVOLINO; PELICIONI, 2001). Além disso, o grupo focal pode ser associado a técnicas como as histórias de vida, as entrevistas abertas e a pesquisa participante. Neste caso, "o pesquisador constrói uma série de possibilidades de informações que lhe permitem levar em conta várias opiniões sobre o mesmo assunto e obter mais informações sobre a realidade" (MINAYO et al., 2004, p. 69).

Em termos de aplicação, o grupo focal é usado principalmente no entendimento de símbolos e significados a cerca de um fato, uma prática, um produto ou um serviço (KRUEGER, 1988). Mas ele também pode ser empregado como método de pesquisa, para a confirmação de hipóteses e a avaliação de uma teoria. Na área da saúde, o grupo focal é cada vez mais usado na estruturação de ações, definição de políticas públicas e diagnóstico de problemas sociais (CARLINI-COTRIM, 1996; LERVOLINO; PELICIONI, 2001).

No que se refere aos procedimentos, a seleção dos participantes é intencional e obedece a critérios definidos pelo pesquisador, de acordo com os objetivos de sua pesquisa. Em alguns casos, fazem-se consultas prévias para apreender o nível de compreensão dos candidatos sobre o tema a ser discutido. Segundo Trad (2009), é recomendável que os 
participantes apresentem algumas características em comum, sobretudo, no que diz respeito ao assunto da discussão. Também é interessante que se conheçam ou possuam algum tipo de vínculo, o que aumenta a efetividade de sua participação. No entanto, não é conveniente escolher somente coordenadores, chefes ou atores políticos, devido à sua implicação direta com a questão. A atenção à equidade de gênero, idade, renda e outras características, é outra questão relevante.

Entre as vantagens da técnica está a aproximação do pesquisador com a população, fato positivo quando se entende que a geração de vínculo aumenta a qualidade das informações coletadas. Outra questão importante é a capacidade da técnica de amplificar as vozes dos grupos sociais e expor os consensos e dissensos desses grupos (ALMEIDA, 2009). Caso se pretenda estabelecer um processo de intervenção, a partir dos dados coletados, este é o ponto positivo.

Entre os limites da técnica estão as dificuldades que os pesquisadores enfrentam em trabalhar com os diferentes sistemas de construção de conhecimento. Sabe-se, neste sentido, que na ciência, o que conduz o processo de geração do saber é o método. Distintamente, na esfera do conhecimento informal, a forma de chegar à verdade é mais imprecisa, possui falhas e obscuridades. Teóricos dessa área sugerem que o essencial, para que o pesquisador consiga enfrentar estes desafios, é construir um diálogo menos rígido, que permita perceber as outras formas de apreender a realidade e construir o conhecimento (THIOLLENT, 2005). Neste sentido, é essencial a abertura do pesquisador para a "compreensão dos problemas do ponto de vista dos grupos populacionais" (LERVOLINO; PELICIONI, 2001, p. 116).

\subsection{A primeira etapa de campo: explorando as primeiras informações, encontrando as primeiras respostas}

A figura 11 orienta a descrição das atividades de campo, realizada a seguir. Trata-se de uma síntese das quatro mais importantes fases da construção progressiva do método. 


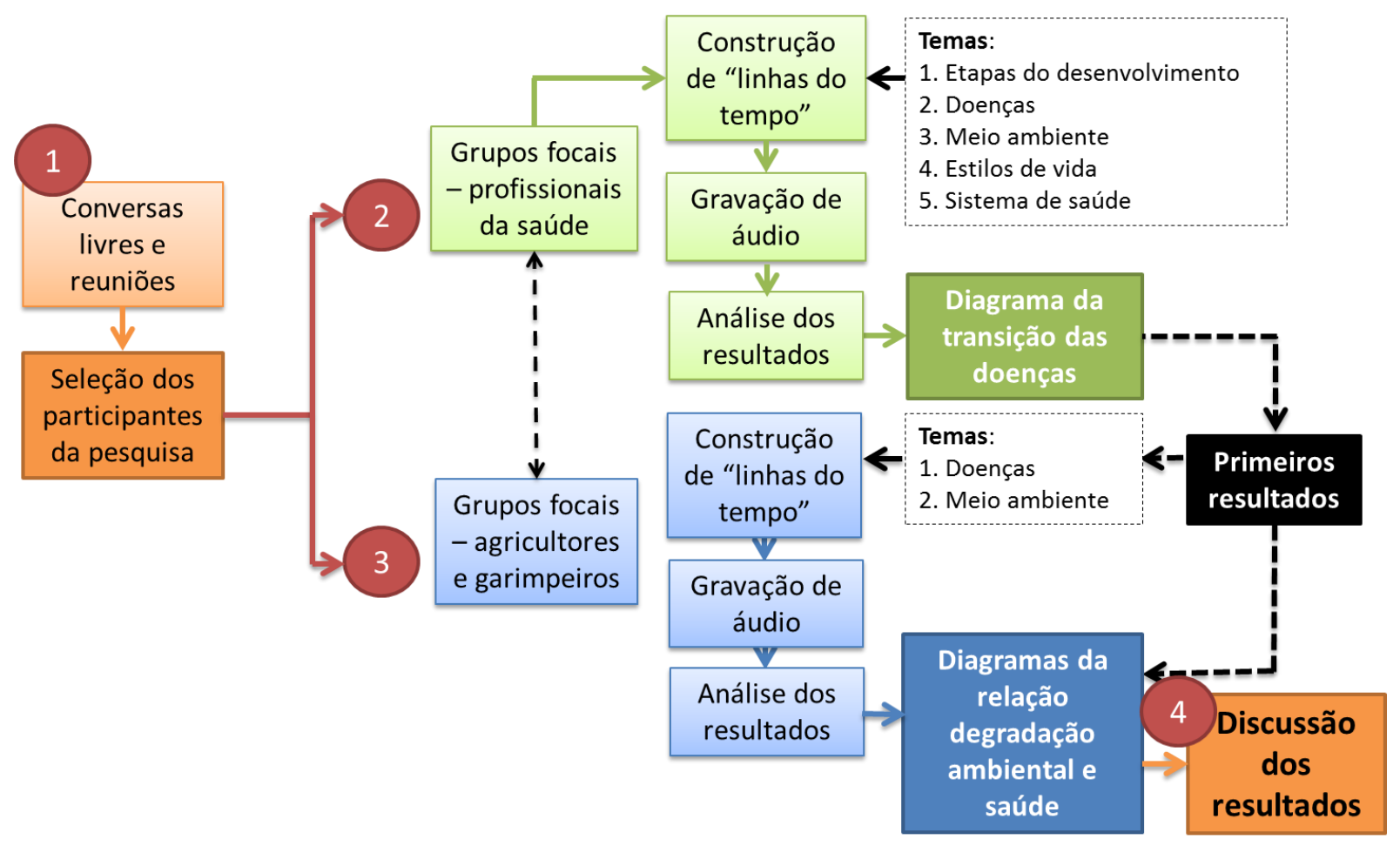

Figura 11 - Etapas do trabalho de campo. Autoria própria.

\subsubsection{Primeira fase: Entrevistas abertas e conversas livres}

A primeira fase da pesquisa de campo foi realizada no mês de março de 2013 , durante aproximadamente três semanas de trabalho. $\mathrm{Na}$ primeira semana, levantamos as informações históricas da região de Alta Floresta: a etapa inicial da ocupação, a migração, a instalação das famílias de agricultores, a chegada dos garimpos, o papel da empresa colonizadora, a organização do sistema de saúde, a urbanização, as principais doenças, as principais formas de degradação ambiental e a fase atual do desenvolvimento (economia, meio ambiente, sociedade e saúde). Estas informações foram obtidas por meio de entrevistas abertas e conversas livres (figura 12). Ambas duravam de 30 minutos a duas horas. Somente as entrevistas eram gravadas ${ }^{66}$. Os pontos mais importantes das conversas eram anotados em caderno de campo, logo após o término da conversa.

${ }^{66}$ Esta foi uma decisão consciente. Em muitos casos, conversávamos com pessoas que se intimidavam com a presença do gravador (aparelho celular). Depois de duas ou três tentativas, desistimos de efetuar a gravação. As anotações, ao final da conversa, conservaram grande parte das informações levantadas. 

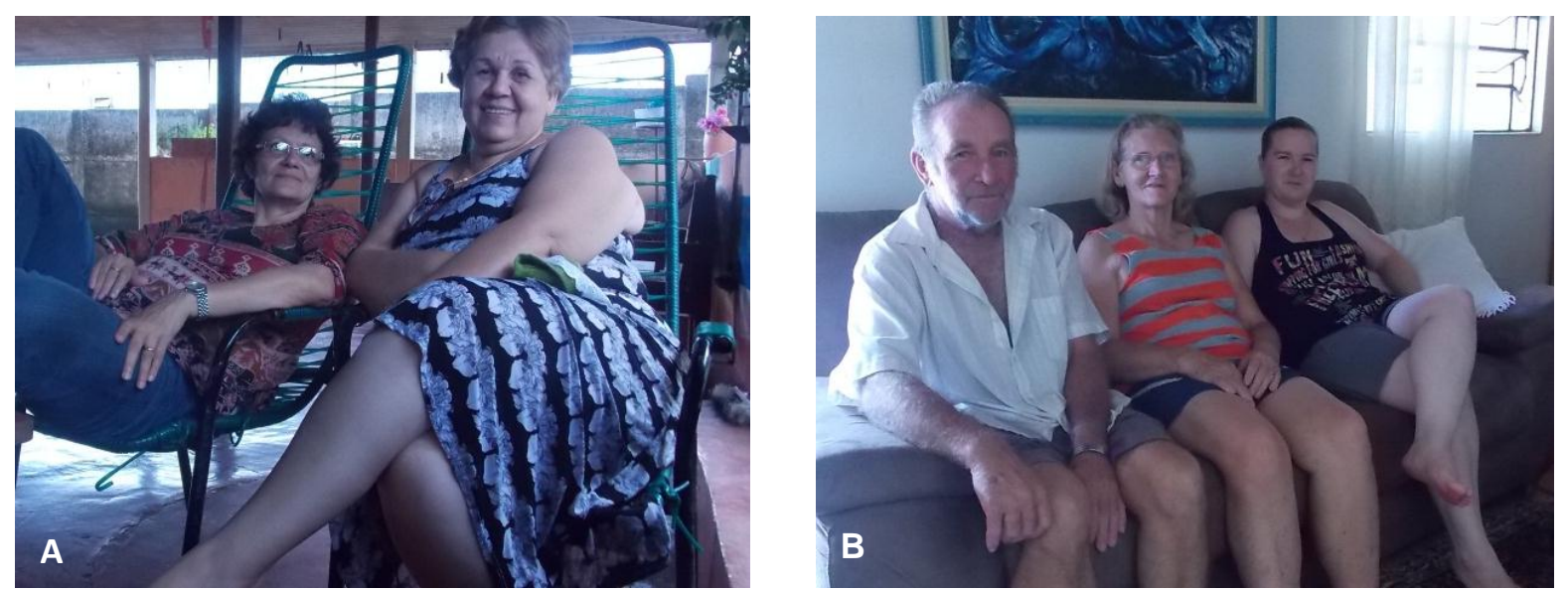

Figura 12 - Alguns dos participantes de entrevistas abertas. A) Uma professora e a viúva de um piloto de avião que trabalhou para os garimpeiros. B) Uma família de agricultores. Fotos: M. Weihs. Pesquisa de campo, março de 2013.

As entrevistas abertas eram guiadas por um roteiro (Anexo I). Elas foram executadas de forma a permitir que os informantes contassem livremente a história do avanço da fronteira de Alta Floresta. As interseções (orientadas pelo roteiro), quando eram efetuadas, visavam dar mais profundidade às reflexões, sobretudo no que dizia respeito ao processo de ocupação, a dinâmica da degradação ambiental e os problemas de saúde.

A seleção dos participantes baseou-se em redes de contato. Neste caso, uma pessoa, que possuía as qualidades de informante que se desejava, indicava uma segunda pessoa, a qual indicava uma terceira ou quarta, e assim por diante. Interessavam-nos os informantes que tinham participado da fase de ocupação da fronteira, entre a década de 1970 e o início dos anos 1990, e que ainda habitam na região. Eles foram selecionados, por esta razão, mas, também, por possuírem certo grau ${ }^{67}$ de compreensão dos problemas da região (ideias, interpretações e representações).

Usamos a nossa percepção do grau ou nível de compreensão da realidade do outro, o informante, com o objetivo de aumentar a qualidade das respostas e reflexões apreendidas por meio das entrevistas e conversas. Entendemos estas interpretações e representações da realidade como crenças, maneira de pensar, opiniões, sentimentos, maneiras de sentir, maneiras de atuar, condutas e projeções para o futuro, entre outros (MINAYO et al., 2004). De forma geral, elas são construídas, pelo indivíduo, a partir de seu ambiente social e suas relações interpessoais (MOSCOVICI, 2000). A sua valorização nos ajudou a melhorar a compreensão de aspectos subjetivos da realidade, dificilmente captados por outros instrumentos de pesquisa (MINAYO et al., 2004).

${ }^{67}$ Esta questão foi incluída em virtude de nossa preocupação com a riqueza das informações. Entendemos, neste sentido, que os informantes que trazem informações relevantes são aqueles que questionam, discutem e buscam entender os problemas regionais. Neste sentido, quando tratamos de "grau de interpretação", estamos nos referindo à formulação de ideias, interpretações e representações sobre o problema. 
Ao todo, realizamos nove entrevistas abertas. Delas participaram pessoas-chaves, como agricultores, ex-garimpeiros, representantes de movimentos sociais, proprietários de hotéis, ex-assessores do grupo fundador ${ }^{68}$ do município e de empresários ${ }^{69}$. 0 objetivo dessa atividade era apreender a maior diversidade e qualidade de informações possível, que contribuíssem para a reconstrução das fases do avanço dessa fronteira.

As entrevistas foram realizadas nas cidades de Alta Floresta, Paranaíta e Carlinda. Isto porque, na versão inicial do projeto de tese, se pretendia incluir estes três municípios na pesquisa. Após análise dos primeiros resultados, o município de Carlinda foi excluído. Esta decisão foi tomada em virtude da grande distinção entre a história deste município ${ }^{70}$ e a dos outros dois: Alta Floresta e Paranaíta. No entanto, os dados coletados em Paranaíta foram incorporados ao estudo. Isto porque se trata de um município criado pela subdivisão territorial de Alta Floresta, ocorrida no final dos anos 1970. As suas características sociais, ambientais e culturais são, portanto, similares às de Alta Floresta.

As conversas livres visavam explorar opiniões e narrativas que ajudassem a compreender aspectos da história da região. Trata-se de uma estratégia menos estruturada de pesquisa e que permite obter uma visão geral do problema (GIL, 2008). Elas foram realizadas sem qualquer roteiro. Fizemos, ao todo, 14 conversas como estas.

O trabalho da primeira semana de campo foi acompanhado de um exaustivo levantamento bibliográfico e documental em bibliotecas públicas, privadas e pessoais e em instituições públicas (livros históricos, trabalhos de conclusão de curso, monografias, dissertações, teses e documentos oficiais). Adicionalmente, foram coletadas fotografias e realizadas visitas ao museu da cidade e à biblioteca municipal. Nesta perspectiva, todas as atividades ficaram restritas ao município de Alta Floresta. Ao todo, foram identificados e coletados mais de 10 estudos desenvolvidos na região, os quais foram fotocopiados e mobilizados na discussão dos resultados.

As informações recolhidas, com o auxilio destas técnicas, subsidiaram: (i) uma aproximação com a história as etapas do avanço da ocupação agrícola dessa fronteira e (ii) a elaboração de um primeiro esboço de uma "linha do tempo". Esta linha foi composta por uma sucessão de etapas de desenvolvimento que marcam o avanço da fronteira em Alta Floresta (agricultura, garimpo, madeira e pecuária) (figura 13). A sua construção teve como objetivo orientar a discussão dos grupos focais.

\footnotetext{
${ }^{68}$ A empresa de colonização INDECO.

${ }^{69}$ Alta Floresta foi o palco inicial do enriquecimento do empresário Eike Batista, um ex-bilionário brasileiro do setor do petróleo, mineração, indústria naval e carvão mineral, entre outros. Nesta região, ele trabalhou com a extração e venda de ouro, durante a fase de garimpo.

${ }^{70}$ Carlinda é um município que foi ocupado por um projeto do INCRA e não pela INDECO, como ocorreu com Alta Floresta e Paranaíta.
} 


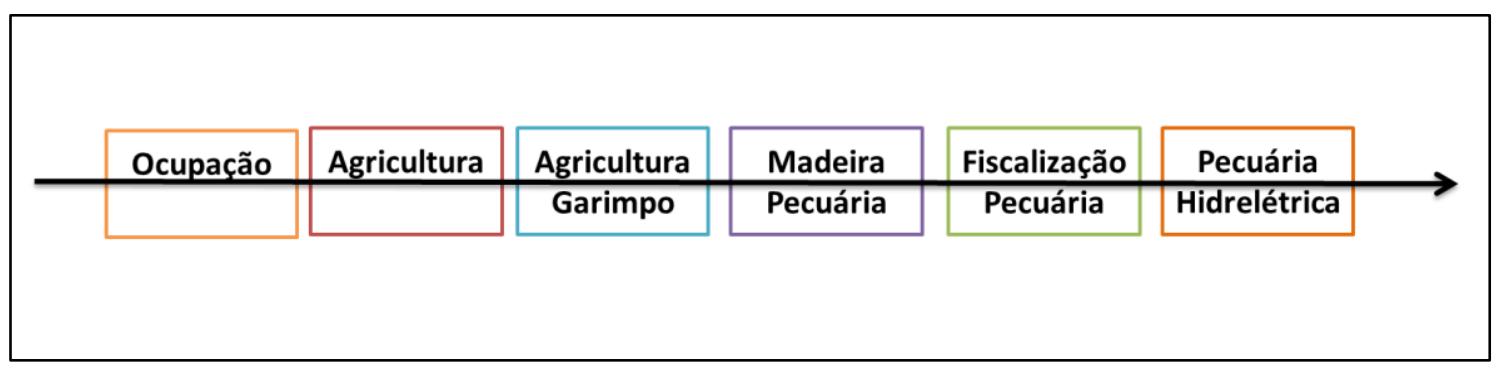

Figura 13 - Primeira "linha do tempo", subsídio para a discussão dos grupos focais formados por profissionais da saúde. Autoria própria.

Este esboço da linha foi testado em uma atividade preliminar de grupo focal realizada com agricultores familiares do município de Nova Xavantina ${ }^{71}$, uma fronteira agrícola localizada na região Nordeste de Mato Grosso. Este teste do método teve como objetivo fundamentar e redefinir a organização da prática, em relação ao tipo e a quantidade de materiais e a adequação dos procedimentos (tipos de perguntas, organização da descrição dos resultados pelos participantes, tempo de discussão de cada pergunta, etc.). Desta forma, foi possível validar a efetividade do uso associado das técnicas (grupo focal + linha do tempo). Os resultados deste teste permitiram repensar alguns detalhes da execução do método. Após algumas adaptações, foi realizada a primeira rodada de grupos focais em Alta Floresta.

\subsubsection{Primeira rodada de grupos focais}

$\mathrm{Na}$ segunda e terceira semanas de trabalho, realizado em março de 2013, foram organizados e executados três grupos focais. Deles participaram profissionais da saúde da (i) Secretaria Municipal de Saúde de Alta Floresta (SMS/AF), do (ii) Escritório Regional de Saúde da microrregião do Alto Tapajós ${ }^{72}$ (ERS), pertencente à Secretaria de Estado de Saúde de Mato Grosso (SES/MT), incluindo profissionais da FUNASA (Fundação Nacional de Saúde), extinta SUCAM (Superintendência de Campanhas de Saúde Pública), e da (iii) Secretaria Municipal de Saúde de Paranaíta (SMS/PT). Em cada grupo, participaram sete pessoas, selecionadas com a ajuda de um ou mais servidores de cada instituição ${ }^{73}$.

\footnotetext{
71 A escolha por esta localidade decorreu de sua proximidade com Brasília e por apresentar características históricas similares às de Alta Floresta.

${ }^{72} \mathrm{O}$ escritório atende aos municípios de Alta Floresta, Carlinda, Paranaíta, Nova Monte Verde, Nova Bandeirantes e Apiacás, localizados no extremo Norte do Estado de Mato Grosso. Ele tem por objetivo organizar a assistência à saúde, em termos de ações de saúde coletiva, e gerir o sistema microrregional no que se refere ao financiamento, a implantação da política da saúde, o sistema de informação, entre outros.

73 Estes servidores foram escolhidos devido à sua participação na história da saúde na região e o conhecimento das equipes de profissionais dos municípios. No caso das secretarias municipais de saúde de Alta Floresta e de Paranaíta, foram duas enfermeiras e ex-secretárias municipais de saúde.
} 
Esta primeira rodada de atividades teve como objetivo: (i) conhecer a evolução da saúde coletiva ao longo das fases do avanço da fronteira e, adicionalmente, (ii) compreender que fatores produziram e controlaram as doenças.

Inicialmente, estabelecemos contato telefônico com um ou dois profissionais de saúde de cada instituição participante. Este primeiro contato serviu para organizar um breve encontro. Nesta reunião, explicamos o objetivo da pesquisa e o método que seria usado com o grupo. Definimos, além disso, algumas das características que se pretendia encontrar nos participantes dos grupos focais: (i) ser servidor do sistema de saúde local e (ii) viver na região há mais de 10 anos. Pedimos à pessoa responsável que selecionasse e convidasse sete ou mais pessoas com esse perfil e que marcasse o local, dia e horário convenientes para cada instituição. Este seria o momento de execução do grupo focal.

No prazo de dois dias a uma semana, depois das respectivas reuniões, todos os encontros, para a realização dos grupos focais, tinham sido marcados. O primeiro foi realizado nas dependências da Secretaria Municipal de Saúde de Alta Floresta e contou com a participação de sete profissionais do sistema local de saúde. Usaremos este evento para descrever a dinâmica da série de grupos focais que realizamos nesta primeira fase de trabalho de campo.

O evento durou em torno de duas horas. Após a chegada, os participantes se organizaram em torno de uma mesa, sobre a qual estava disposta a cartolina com o esboço da linha do tempo. No primeiro momento, reforçamos o convite para a participação na pesquisa e solicitamos a confirmação do interesse de cada um dos profissionais. Em seguida, explicamos os objetivos do estudo e convidamos os participantes a se apresentar e comentar brevemente a sua experiência no sistema de saúde local.

No momento subsequente, distribuímos a cada um participantes um bloco composto por pequenos papeis, lápis, borracha e cola. Somente após este procedimento, explicamos as etapas da atividade. Apresentamos a linha do tempo, seguida da seguinte questão: "Vocês concordam com a divisão da história de Alta Floresta nestas etapas (agricultura familiar, garimpo, madeira e pecuária)?". Pedimos que, caso não houvesse concordância com a linha apresentada, uma pessoa fizesse as devidas alterações de acordo com a proposição do grupo. Duas etapas foram alteradas. De uma parte, o grupo discordou da divisão entre (i) ocupação, (ii) agricultura e (iii) agricultura e garimpo. Para eles, estas três etapas representavam uma só, que durou de 1976 a 1992. De outra parte, foi acrescentada a etapa que corresponde à expansão da produção de soja, na fase atual do

No caso do Escritório Regional, foi uma servidora que havia ocupado a chefia da instituição em períodos anteriores. 
desenvolvimento. Nos demais grupos focais, que realizamos durante a semana seguinte, as modificações foram similares.

Lançamos, em seguida, a segunda pergunta: Em cada uma dessas etapas do desenvolvimento de Alta Floresta, quais foram as principais doenças que afetaram a população? Os participantes discutiram a questão para cada etapa e à medida que iam lembrando-se das doenças, marcavam-nas nos pequenos papeis e colavam na cartolina. Neste interim de tempo de discussão, nossa participação ficou restrita à observação. Vez ou outra, nós apenas repetíamos a pergunta. A discussão desta questão, acompanhada das respectivas anotações, durou em torno de 40 minutos.

Concluída esta fase, lançamos a terceira pergunta: Como se comportou o sistema de saúde, em termos de infraestrutura e atendimento, em cada uma dessas fases? O ritual anterior se repetiu. Contudo, desta vez fomos obrigados a intervir com certa frequência. É que emergiam, durante as discussões, várias histórias particulares ou lembranças de eventos que não interessavam ao estudo. Para desviar destes assuntos, pedíamos que as respostas fossem refinadas de forma a responder apenas a questão proposta. Repetimos a questão por diversas vezes. Conseguimos concluir esta fase em menos de 40 minutos.

A quarta questão foi: Quais foram as formas de degradação e contaminação do meio ambiente que ocorreram em cada uma das fases? Novamente o ritual de discussões e anotações se repetiu. Mas, desta vez, alguns participantes, que haviam participado de projetos executados pela Prefeitura Municipal e por ONGs locais, com o intuito de reduzir as taxas de queimadas e desmatamento, ocuparam a maior parte do tempo com as suas descrições. Neste contexto, apareceram os detalhes de maior importância para a compreensão da dinâmica da mobilização local em resposta à pressão dos órgãos ambientais, depois do ano 2000. Concluímos esta fase em menos de 30 minutos. Nos demais grupos focais esta discussão foi menos calorosa e contribuiu menos em termos de resultados da pesquisa.

A quinta questão tratou das mudanças nos estilos de vida, incluindo a evolução das questões sociais e econômicas. Como elas se manifestaram ao longo do tempo?, perguntamos. Alguns das respostas já haviam aparecido em questões anteriores. Desta forma, o que se observou foi uma rápida discussão, seguida de algumas poucas anotações. Elas destacavam essencialmente as variações no perfil dos riscos. Um ponto de destaque foram as recentes mudanças observadas nos hábitos de consumo, principalmente entre as populações mais pobres.

Ao final, pedimos aos participantes que verificassem qualquer incongruência nas informações dispostas na linha do tempo e que fizessem as correções que julgassem 
necessárias. Dois pontos foram rediscutidos e apagados após consenso do grupo. Todas as discussões foram gravadas e os encontros foram fotografados (figura 14).
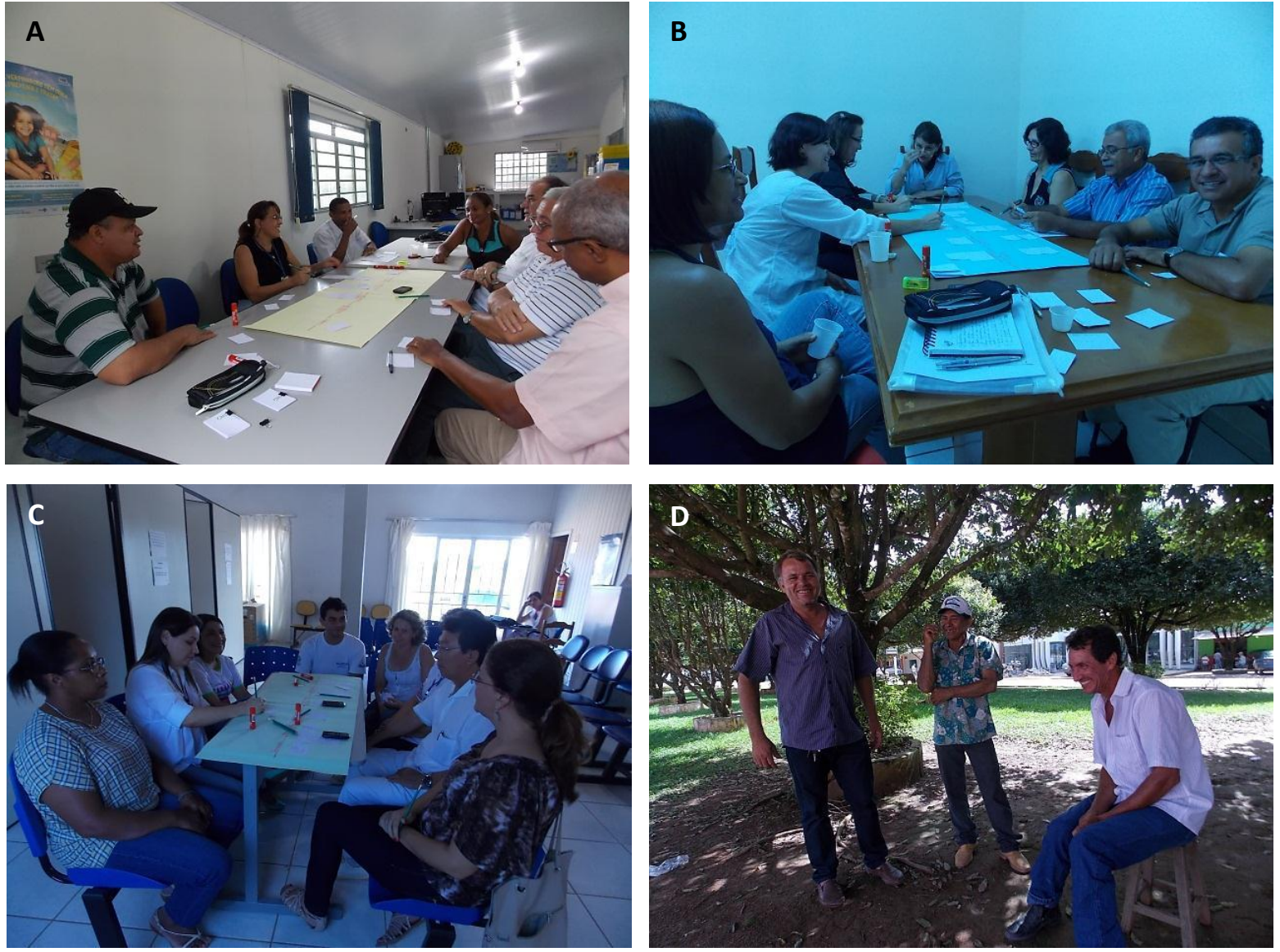

Figura 14 - Grupos focais e conversas informais (1afase). A) Profissionais do Escritório Regional da microrregião do Alto Tapajós da Secretaria de Estado de Saúde de Mato Grosso e da FUNASA (antiga SUCAM). B) Profissionais da Secretaria Municipal de Saúde de Alta Floresta. C) Profissionais da Secretaria

Municipal de Saúde de Paranaíta. E) Agricultores do Assentamento de Reforma Agrária "São Pedro", emigrados de Alta Floresta para Paranaíta nos anos 2000. Fotos: M. Weihs. Pesquisa de campo, março de 2013.

Além disso, os participantes assinaram um "termo de consentimento libre e esclarecido" (Anexo II). O objetivo do documento foi obter autorização para a gravação e publicação das informações fornecidas. Ademais, o documento permitiu obter informações específicas dos participantes dos grupos focais, como idade, formação universitária, local de origem, ano em que ingressou no sistema de saúde e atividade exercida. A título de conhecimento, estas informações são apresentadas no quadro 1. 
Quadro 1. Informações gerais dos participantes da primeira etapa dos grupos focais.

\begin{tabular}{|c|c|c|c|c|c|c|}
\hline Setor & Sexo & Formação & Atividade profissional & $\begin{array}{l}\text { Ingresso } \\
\text { no SUS }^{4}\end{array}$ & Origem & Idade \\
\hline \multirow{7}{*}{ ERS $^{1} /$ SES } & 0 & $\begin{array}{l}\text { Técnico de } \\
\text { laboratório }\end{array}$ & $\begin{array}{l}\text { Vigilância de doenças } \\
\text { infecciosas }\end{array}$ & 1982 & MT & 55 \\
\hline & $0^{\lambda}$ & $\begin{array}{l}\text { Agente de saúde } \\
\text { pública }\end{array}$ & Fiscal sanitário & 1983 & $M G$ & 51 \\
\hline & $0^{\lambda}$ & $\begin{array}{l}\text { Agente de saúde } \\
\text { pública }\end{array}$ & $\begin{array}{l}\text { Vigilância de doenças } \\
\text { infecciosas }\end{array}$ & 1983 & $M G$ & 62 \\
\hline & q & Psicologia & Técnica do SUS & 1987 & MT & 49 \\
\hline & $\hat{0}$ & Pedagogia & Vigilância imunobiológica & 1990 & MT & 40 \\
\hline & q & $\begin{array}{l}\text { Pedagogia e } \\
\text { Assistência social }\end{array}$ & $\begin{array}{l}\text { Vigilância de doenças } \\
\text { infecciosas }\end{array}$ & 1993 & MA & 38 \\
\hline & $\hat{0}$ & Administração & Administração hospitalar & 1997 & $\mathrm{BA}$ & 53 \\
\hline \multirow{7}{*}{ SMS/AF ${ }^{2}$} & q & Administração & Técnica do SUS & - & MS & 62 \\
\hline & q & $\begin{array}{l}\text { Técnico em } \\
\text { enfermagem }\end{array}$ & Técnica do SUS & 1987 & GO & 51 \\
\hline & $\hat{0}$ & $\begin{array}{l}\text { Técnico em } \\
\text { vigilância em } \\
\text { saúde }\end{array}$ & Fiscal sanitário & 1987 & MS & 49 \\
\hline & 우 & Enfermagem & $\begin{array}{l}\text { Coordenadora da atenção } \\
\text { básica }\end{array}$ & 1988 & PR & 47 \\
\hline & 우 & Odontologia & Cirurgiã dentista & 1993 & PR & 51 \\
\hline & q & Enfermagem & $\begin{array}{l}\text { Vigilância de doenças } \\
\text { infecciosas }\end{array}$ & 1996 & PR & 57 \\
\hline & $\hat{0}$ & Biologia & Saúde escolar & 2007 & MG & 58 \\
\hline \multirow{7}{*}{$\mathrm{SMS} / \mathrm{PT}^{3}$} & q & $\begin{array}{l}\text { Técnico em } \\
\text { enfermagem }\end{array}$ & Técnica em enfermagem & 1982 & PR & 45 \\
\hline & $0^{\lambda}$ & $\begin{array}{l}\text { Técnico em } \\
\text { enfermagem }\end{array}$ & Assessor hospitalar & 1994 & PR & 44 \\
\hline & q & $\begin{array}{l}\text { Enfermagem e } \\
\text { obstetrícia }\end{array}$ & Enfermeira & 1999 & PR & 41 \\
\hline & q & Enfermagem & $\begin{array}{l}\text { Coordenadora da atenção } \\
\text { básica e vigilância da } \\
\text { saúde }\end{array}$ & 2000 & PR & 35 \\
\hline & $\hat{0}$ & Pedagogia & Auditor de saúde pública & 2001 & $\mathrm{SP}$ & 30 \\
\hline & $\hat{0}$ & Medicina & Médico - Clínico geral & 2003 & PR & 60 \\
\hline & o & $\begin{array}{l}\text { Técnico em } \\
\text { contabilidade }\end{array}$ & Técnica do SUS & 2005 & PR & 47 \\
\hline
\end{tabular}

${ }^{1}$ Escritório Escritório Regional de Saúde da microrregião do Alto Tapajós/Secretaria de Estado de Saúde de Mato Grosso, incluindo profissionais da FUNASA.

${ }^{2}$ Secretaria Municipal de Saúde de Alta Floresta

${ }^{3}$ Secretaria Municipal de Saúde de Paranaíta.

${ }^{4}$ Sistema Único de Saúde.

$\checkmark$ Sexo masculino e $\bigcirc$ sexo feminino.

As gravações foram posteriormente ouvidas e as informações de maior importância foram organizadas em tabelas (anexo II). A partir delas, criamos diagramas e selecionamos citações para ser usadas durante a fase de descrição dos resultados. 


\subsubsection{Segunda rodada de grupos focais}

A partir dos resultados da primeira fase dos grupos focais elaboramos uma segunda linha do tempo (figura 15). Nessa, foram esboçadas, além das etapas do avanço da fronteira, o comportamento (etapas de emergência e controle) das principais doenças (malária, doenças respiratórias e crônicas), detectadas na etapa anterior da pesquisa de campo.

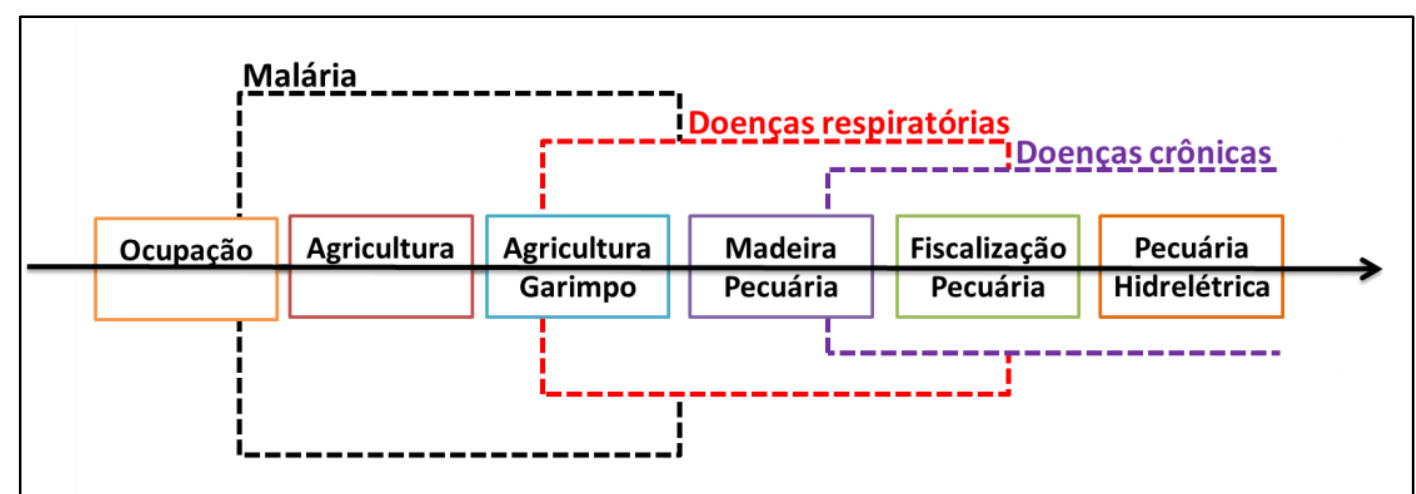

Figura 15 - Segunda "linha do tempo", subsídio para a discussão dos grupos focais formados por agricultores, trabalhadores rurais e ex-garimpeiros. Autoria própria.

Esta segunda linha do tempo serviu de guia para as discussões de um único grupo focal, formado por agricultores, trabalhadores rurais e ex-garimpeiros. Nessa nova configuração, alterou-se o objetivo da atividade. Nessa fase, o foco da discussão foi apenas o conjunto de fatores ambientais e sociais que determinaram a emergência e o controle das doenças de maior importância em termos de saúde pública.

A segunda fase de campo foi realizada em agosto de 2014. Dela participaram trabalhadores que habitam, atualmente, um dos mais antigos bairros de Alta Floresta (denominado "Vila Nova").

A seleção dos participantes foi iniciada no posto de saúde do referido bairro. A partir de um primeiro contato com uma agente de saúde ${ }^{74}$, foi marcada uma breve reunião com todo o grupo de agentes (oito profissionais). Usamos a reunião para explicar o objetivo da pesquisa e esclarecer o papel dos moradores, que seriam convidados, para participar do trabalho do grupo focal. Deste modo, delineamos o perfil das pessoas que gostaríamos de encontrar. Depois de todos os esclarecimentos, solicitamos a cada uma das agentes de saúde que convidasse uma ou duas pessoas de sua área de atuação. Para a seleção dos participantes, dever-se-ia considerar as seguintes características: (i) ter participado da ocupação da região desde a década de 1970 ou 1980, (ii) ser agricultor, garimpeiro ou trabalhador rural (aposentado ou não) e (iii) incluir homens e mulheres.

\footnotetext{
${ }^{74}$ Agentes de saúde são os profissionais que operacionalizam as ações de prevenção e promoção de saúde nos bairros, acompanhando as pessoas por meio de visitas semanais às residências.
} 
A reunião do grupo focal foi realizada nas dependências do próprio posto de saúde e durou aproximadamente duas horas. Aqui também, o grupo foi formado por sete pessoas. Neste caso, antes de iniciar a atividade foi realizada uma conversa com os participantes (que se autodenominavam "pioneiros"). Ela durou aproximadamente uma hora. O objetivo foi melhor conhecer essas pessoas, suas trajetórias e o grau de compreensão do problema da pesquisa

A organização da atividade foi similar à etapa anterior. Contudo, desta vez, o esboço da linha do tempo não partiu das informações basilares, como foi comentado no início desta seção. A discussão se concentrou, prioritariamente, em torno das doenças e dos problemas ambientais.

No começo da atividade, foi explicado o conteúdo da linha do tempo, bem como, sua origem e significado. Esta explicação demandou uma série de detalhes e o esclarecimento de diversas dúvidas. Nas etapas seguintes, o desenvolvimento da atividade seguiu os mesmos passos e ateve-se aos mesmos cuidados da primeira fase dos grupos focais. As perguntas que orientaram a discussão foram: "Vocês concordam que a malária tenha ocorrido durante esse período? O que gerou a malária? O que controlou a malária?". As mesmas questões foram repetidas para as demais doenças (respiratórias e crônicas). Os grupos discutiram as respostas, uma a uma, enquanto anotávamos os pontos de consenso na cartolina ${ }^{75}$ (figura 16). Antes do encerramento, os participantes avaliaram as respostas mais comentadas. Todas as discussões foram gravadas. Todos os participantes (figura 17) preencheram e assinaram um "termo de consentimento libre e esclarecido". Controlar a ansiedade dos participantes e organizar a separação das falas, em tempos diferentes, foram os principais desafios desta etapa.

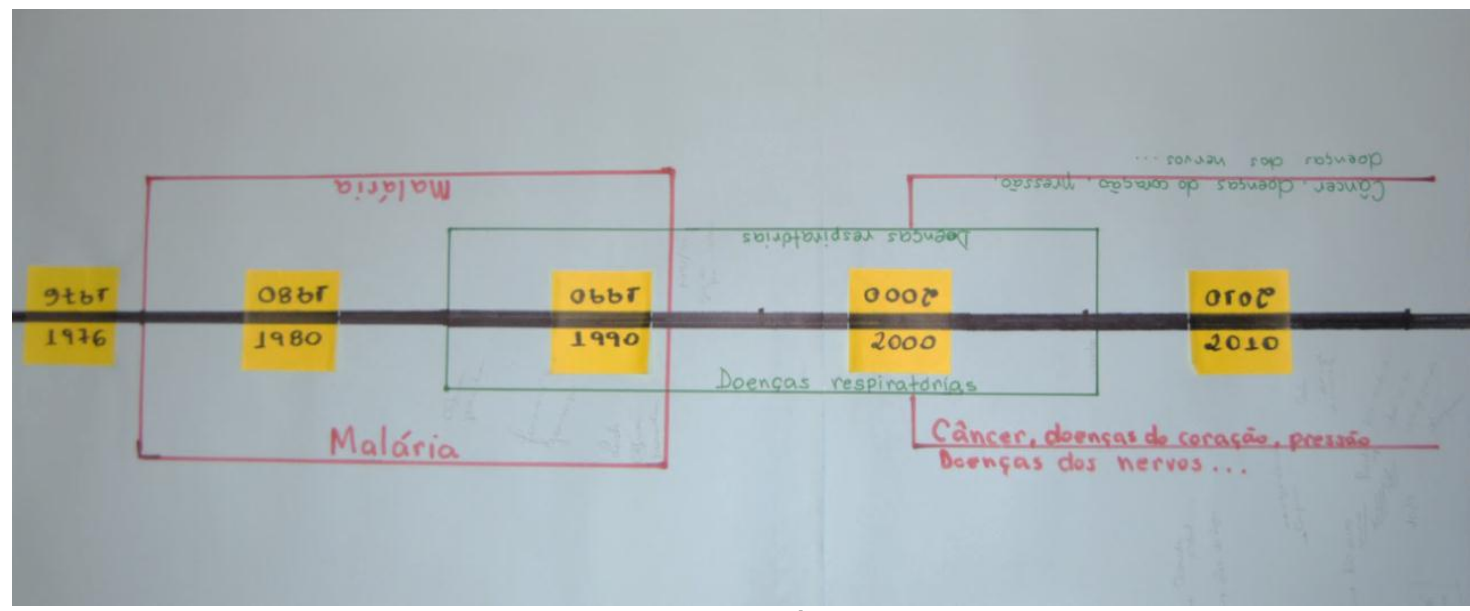

Figura 16 - Exemplo de uma linha do tempo construída pelos participantes da segunda etapa de grupos focais. Foto: M. Weihs. Fonte: Pesquisa de campo, agosto de 2014.

\footnotetext{
${ }^{75}$ Neste grupo, não foi possível esperar que as pessoas anotassem as respostas. Esse processo os acanhava, então consideramos melhor nós mesmos fazê-lo.
} 


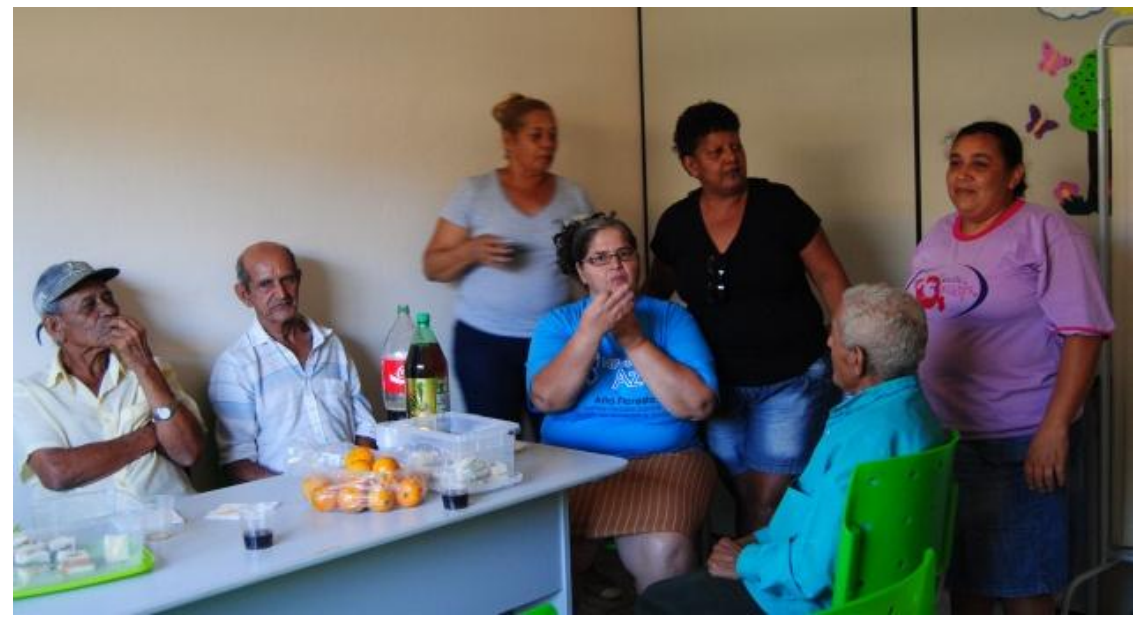

Figura 17 - Moradores do bairro Vila Nova (agricultores e trabalhadores rurais), participantes do último grupo focal. Foto: M. Weihs. Pesquisa de campo, agosto de 2014.

\subsection{A organização dos resultados}

Em primeira mão, as informações coletadas em todas as fases, anotadas ou gravadas, foram agrupadas por similaridade (Anexo III). Formaram-se, por conseguinte, conjuntos de dados que contribuíram para: (i) caracterizar as etapas do avanço da fronteira (agricultura, garimpo, madeira, pecuária, etc.), (ii) analisar as formas de degradação ambiental e (iii) apreender a evolução da saúde coletiva. Esta sistematização permitiu que se percebessem as particularidades de cada fase da fronteira em termos de degradação ambiental e saúde.

Num segundo momento, construímos diagramas, que visaram permitir a visualização do comportamento global da relação meio ambiente e saúde na fronteira. Esta diagramação resultou de uma análise detalhada das informações agrupadas por similaridade. Ela permitiu que se analisassem e discutissem as conexões entre as partes (formas de uso e ocupação do espaço $\leftrightarrow$ degradação ambiental $\leftrightarrow$ perfil epidemiológico $\leftrightarrow$ participação do sistema de saúde). A compreensão destas conexões ofereceu uma visão global da evolução do sistema (a fronteira), em termos de saúde ambiental.

As informações de campo e os diagramas foram discutidos na interface com resultados de estudos epidemiológicos desenvolvidos em Alta Floresta. Os detalhes dessa discussão são encontrados no capítulo nove da tese.

Os resultados da pesquisa de campo foram apresentados e discutidos com a comunidade local em um evento organizado pela UNEMAT em novembro de $2014^{76}$. Realizamos, nesse momento, a apresentação da síntese das discussões da pesquisa e

\footnotetext{
${ }^{76}$ VII Semana da Biologia e II Semana do Jornalismo, que aconteceu entre 10 e 16 de novembro de 2014, em Alta Floresta - MT.
} 
abrimos a discussão para receber contribuições dos participantes (figura 18). Ao todo, foram realizadas duas horas de discussão, da qual participaram cerca de 70 estudantes, professores, pesquisadores e demais membros da sociedade local. Dentro do possível, as contribuições foram incluídas na discussão dos resultados.

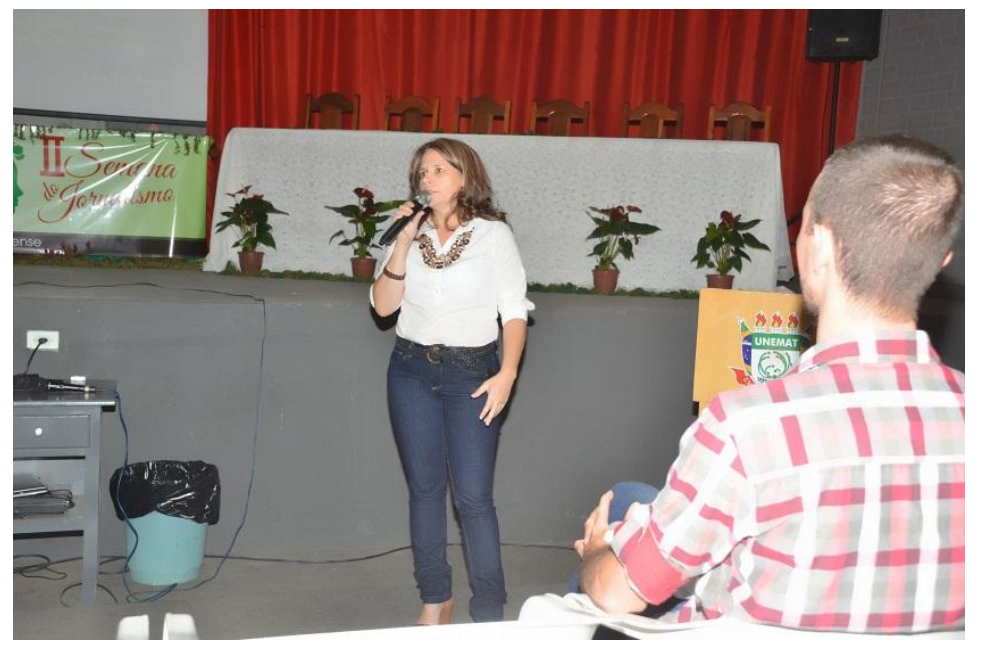

Figura 18 - Fase de restituição dos resultados preliminares. Pesquisa de campo, novembro de 2014.

\subsection{Alguns limites do método e os meios para superá-los}

Como qualquer pesquisa, o método aqui adotado apresenta limites. Eles se encontram, fundamentalmente, nas dificuldades em selecionar os participantes que apresentam o perfil que se deseja. Isto porque se trabalha com um grupo pequeno de informantes, intentando valorizar as informações em profundidade. Caso ocorram falhas na seleção desses participantes, corre-se o risco de não conseguir avançar, em termos de compreensão da complexidade que o tema impõe. As informações obtidas podem nada ou pouco ajudar a compreender o objeto de estudo.

$\mathrm{Na}$ ciência destes limites, investiu-se na definição clara de uma série de critérios que balizaram as etapas do trabalho de campo: (i) a repetição de levantamentos para avaliar a qualidade dos dados obtidos, (ii) o rigor na seleção dos participantes, observando cuidadosamente os aspectos que os incluía ou excluía da pesquisa e (iii) os cuidados com a condução dos grupos focais, evitando a perda do foco da atividade e dos temas em discussão, bem como, com as intervenções, durante o processo, vigiando para que não interferíssemos no resultado das discussões.

De forma mais ampla, o alicerce oferecido pela ecossaúde e as orientações apreendidas da AMESH deram mais segurança à atividade de campo. Ademais, vale ressaltar que já havíamos experimentado este tipo de método anteriormente em projetos desenvolvidos na região. Em qualquer uma das experiências, o cuidado na aplicação das 
técnicas de pesquisa de campo, na sistematização e esquematização dos resultados, tem sido nossa preocupação constante.

\section{Conclusão}

Neste capítulo descremos o método adotado nesta pesquisa. O método foi adaptado a partir dos fundamentos teóricos e metodológicos da ecossaúde, notadamente, no que se refere à participação e transdisciplinaridade. A participação é entendida como o envolvimento recíproco entre pesquisador e o grupo pesquisado. Este envolvimento toma corpo, nesta pesquisa, a partir da organização e realização de grupos focais.

Cabe ressaltar, neste sentido, que as atividades de campo foram construídas progressivamente, de modo que os resultados de uma etapa ofereciam subsídios para a realização da próxima. Assim, partindo de entrevistas abertas e conversas informais, conseguimos organizar os grupos focais. Na maior parte das atividades, foi dada prioridade aos profissionais de saúde. Esta escolha se deve à percepção de que eles possuíam uma compreensão mais ampla do perfil epidemiológico e de seus determinantes. Por fim, o último grupo, formado por agricultores, trabalhadores rurais e ex-garimpeiros esgotou a coleta de dados. Este fechamento foi decidido em razão da complementariedade com as informações já coletas e a saturação de informações novas. 
- Terceira Parte -

ALTA FLORESTA:

DEGRADAÇÃO AMBIENTAL E SAÚDE NA FRONTEIRA AGRÍCOLA 


\section{Capítulo 7. FRONTEIRA AGRÍCOLA EM ALTA FLORESTA: FORMAS DE USO E OCUPAÇÃO DO ESPAÇO E TRANSIÇÃO DE DOENÇAS}

\section{Introdução}

Este capítulo é dedicado à descrição das informações de campo. O objetivo é oferecer as bases para a análise e a discussão da relação entre a degradação ambiental e a saúde coletiva, que são realizadas nas próximas seções. Trabalha-se, neste sentido, com duas dimensões: (i) uma breve reconstrução do avanço da ocupação agrícola da região de Alta Floresta e (ii) a apresentação das principais doenças que afetaram a população local, no curso deste avanço da ocupação da fronteira. Adicionalmente, faz-se uma breve descrição da história do sistema de saúde, dando ênfase às mudanças das abordagens do sistema e seus impactos ao perfil epidemiológico local.

As informações apresentadas se baseiam na percepção dos participantes dos grupos focais. Trata-se de um conhecimento constituído a partir dos elementos que esses grupos possuem, os seus signos tradicionais e populares e seus saberes, elaborados em interação com o conhecimento científico (LAPLANTINE, 2001; MINAYO, 2006). Em outras palavras, os ingredientes da análise aqui apresentada são as construções sociais que dão vida ao território (BERGER; LUCKMANN, 1995). Elas permitem que a fronteira agrícola seja caracterizada a partir das concepções daqueles que a constroem.

O texto é enriquecido com citações que reproduzem, de forma fidedigna, algumas falas e narrativas. Além disso, os resultados são apresentados, na maior parte das vezes, na forma de diagramas, que foram construídos a partir da síntese das informações coletadas em campo. A discussão dessas citações e diagramas, por sua vez, é complementada com proposições teóricas obtidas em teses, artigos científicos e outras fontes bibliográficas. Vale ressaltar que a ausência de dados oficiais, em algumas partes do texto, se explica, em grande medida, pela baixa disponibilidade e/ou fragilidade das informações administradas pelo Ministério da Saúde, sobretudo no que se refere às décadas de 1970 a 1990.

\subsection{A ocupação agrícola}

\subsubsection{O desenvolvimento da agricultura}

Em termos de produtividade agrícola, a primeira fase da ocupação, efetivamente iniciada em 1976, foi marcada por importantes crises. O investimento nas lavouras de café 
não obteve o sucesso esperado. A variedade escolhida não se adaptou às condições ambientais da região. A produtividade, a qualidade e, portanto, a rentabilidade do produto era muito baixa (JATENE, 1983). Aos poucos, os agricultores foram substituindo as plantações de café por lavouras temporárias, principalmente de arroz, feijão e milho, e outras culturas perenes, como o cacau e o guaraná. Contudo, os solos não eram tão férteis quanto se esperava, faltava assistência técnica e os canais de distribuição e venda da produção não estavam suficientemente estruturados (BRASIL, 2001; MOREIRA, 2014). Além disso, grande parte das rodovias não era asfaltada e as chuvas prejudicavam a circulação dos caminhões nas estradas rurais. Por consequência, parte da produção perdiase nas próprias propriedades. Esse processo provocou o retorno de várias famílias para as suas regiões de origem ou, ainda, a migração para novas fronteiras agrícolas da Amazônia (CUNHA, 2006).

Depois de uma década de ocupação, duas crises já haviam afetado o desenvolvimento da região: a do café e a das lavouras temporárias. Para os agricultores que permaneceram na região, a alternativa foi transformar as áreas agrícolas em pastagens e comprar gado, o que significava uma menor dependência das condições climáticas e da logística de comercialização (MIRANDA, 1990). Paralelamente, as melhorias da infraestrutura e o aumento do preço da madeira tornou viável o extrativismo madeireiro.

No entanto, a principal atividade econômica regional, entre os anos 1980 e 1990, foi o garimpo de ouro. Parte dos agricultores apostou na abertura dos garimpos, adquirindo pequenas áreas potencialmente ricas em ouro. Em termos de desenvolvimento regional, os impactos desta mudança foram significativos. Alta Floresta se tornou um dos maiores centros de garimpagem de ouro do país (PEREIRA FILHO, 1995).

\subsubsection{Entre a agricultura e o garimpo de ouro}

Depois de 1978, o boato da existência de ouro na região correu o Brasil. À época, a disponibilidade de ouro em Serra Pelada, no Estado do Pará - o maior garimpo a céu aberto $^{77}$ da história do país -, estava no limite das reservas. Além disso, uma importante crise financeira ganhava o país naquele período, afetando, sobretudo, os pequenos produtores rurais dos Estados do Nordeste e do Norte. Por fim, o preço do ouro no mercado

\footnotetext{
${ }^{77}$ Os garimpos de céu aberto se caracterizavam pela exploração de aluviões ou rochas mineralizadas aflorantes. As atividades são desenvolvidas sem qualquer planejamento e as técnicas utilizadas são fortemente predatórias ao meio ambiente (assoreamento de rios, desmatamento e contaminação ambiental por mercúrio). Trata-se de um tipo de garimpo que tem caráter ilegal (clandestino) e gera uma série de problemas sociais, em virtude da falta de infraestrutura, da baixa qualidade de vida dos trabalhadores e a insegurança no trabalho. Além disso, eles também estão associados ao alto consumo de álcool e à proliferação da prostituição, DSTs e da violência.
} 
internacional era animador. Estes fatores estimularam milhares de trabalhadores rurais e garimpeiros a migrar para os novos garimpos. Alta Floresta estava na lista dos locais mais promissores para a realização desta atividade (PEREIRA FILHO, 1995).

Estima-se que somente no ano de 1978, Alta Floresta tenha recebido mais de 10 mil garimpeiros (ARAÚJO, 1999). Nos anos seguintes, o fluxo populacional cresceu ainda mais. Os números oficiais são ambíguos, uma vez que se tratava de uma população móvel, difícil de ser contada. Segundo Paulo ${ }^{78}$, um dos entrevistados, no início dos anos 1980, contavase cerca de 20 ônibus por dia, chegando à cidade, lotados de migrantes. Outros entrevistados confirmaram que, em poucos anos, a população teria passado de 10 a 15 mil para mais de 100 mil pessoas. No extremo, falam-se até em 140 mil pessoas. Eram trabalhadores, em sua maioria do sexo masculino, com idade entre 25 e 40 anos. Eles tinham como objetivo melhorar as condições econômicas da família, deixada em sua região de origem.

O município se tornou um polo regional devido à produção de ouro (HOGAN et al., 2000). Calcula-se que aproximadamente 25 toneladas de ouro tenham sido purificadas e comercializadas anualmente durante a década de 1980 e o início dos anos 1990 (HACON et al., 1997b).

A atividade garimpeira entrou em declínio no início dos anos 1990. Ela foi condicionada pela redução dos depósitos de ouro de superfície. Na falta de recursos para investir em novas tecnologias, um número cada vez maior de garimpeiros migrou para outras regiões. Por fim, em 1992, com a baixa no valor do ouro e o aumento no preço do óleo diesel, provocados pelo "Plano Collor" ${ }^{\text {") }}$, os últimos garimpos foram desativados (BARBIERI; SAWYER, 2007).

O declínio da atividade garimpeira provocou uma drástica evasão populacional, com perda de aproximadamente $30 \%$ da população. Segundo dados do IBGE (2013), o número de habitantes de Alta Floresta baixou de 67 mil, em 1991, para 47 mil, em 2000.

\footnotetext{
${ }^{78}$ Os nomes verdadeiros dos participantes foram mantidos.

${ }^{79}$ O "Plano Collor" (Plano Brasil Novo) foi um pacote, lançado pelo governo Fernando Collor de Mello (1990-1992), em março de 1990. A medida emergencial visava a modernização administrativa e vitalização da economia. Entre outras ações, ela promovia: a volta do Cruzeiro como moeda, o congelamento de preços e salários, o bloqueio de contas correntes e poupanças no prazo de 18 meses, a demissão de funcionários e redução de departamentos e órgãos públicos e a eliminação de vários tipos de incentivos fiscais para importações, exportações, agricultura, etc. O objetivo principal era a estabilização da inflação. O resultado foi uma profunda recessão, desemprego e insatisfação popular. Nos garimpos, o plano gerou prejuízos devido à brusca queda do preço interno do ouro e o aumento do preço dos insumos usados na extração do minério.
} 


\subsubsection{O avanço da pecuária}

A atividade pecuária vinha se fortalecendo como atividade econômica desde os anos 1980, no entanto, apenas a partir da década de 1990, com a instalação de redes de frigoríficos e laticínios, a atividade se fortaleceu (SABOURIN; RODRIGUES, 2010). Nas grandes fazendas, ela se concentrou na produção de carne e, na pequena propriedade, vigorou a pecuária leiteira, uma tendência observada nas fronteiras agrícolas amazônicas em geral (PIKETTY et al., 2005).

A produção de leite é hoje a principal atividade econômica de 1.300 dos 1.500 estabelecimentos agrícolas familiares do município. São produzidos em média 39 mil litros por dia (2\% da produção total do Estado de Mato Grosso) (IBGE, 2014b). Além dessa atividade, também se verifica na pequena propriedade, uma agricultura familiar ${ }^{80}$ voltada para a criação de suínos e a produção de cana-de-açúcar, pupunha, cupuaçu, guaraná, mandioca e milho, além de hortaliças e mel (BRASIL, 2005). Ao todo, esses estabelecimentos agrícolas ocupam menos $18 \%$ da área municipal destinada à agropecuária (menos de 95.000ha), enquanto responde por mais de $70 \%$ dos trabalhadores ocupados no campo (BRASIL, 2005; IBGE, 2014b).

O rebanho bovino aumentou de 19 mil cabeças, em 1981, para 850 mil, em 2012 (gráfico 4). Para se ter a dimensão desses números, existem hoje, para cada habitante do município, 17 cabeças de gado. Em torno de $85 \%$ dessa produção é desenvolvida em grandes fazendas (IBGE, 2014a).

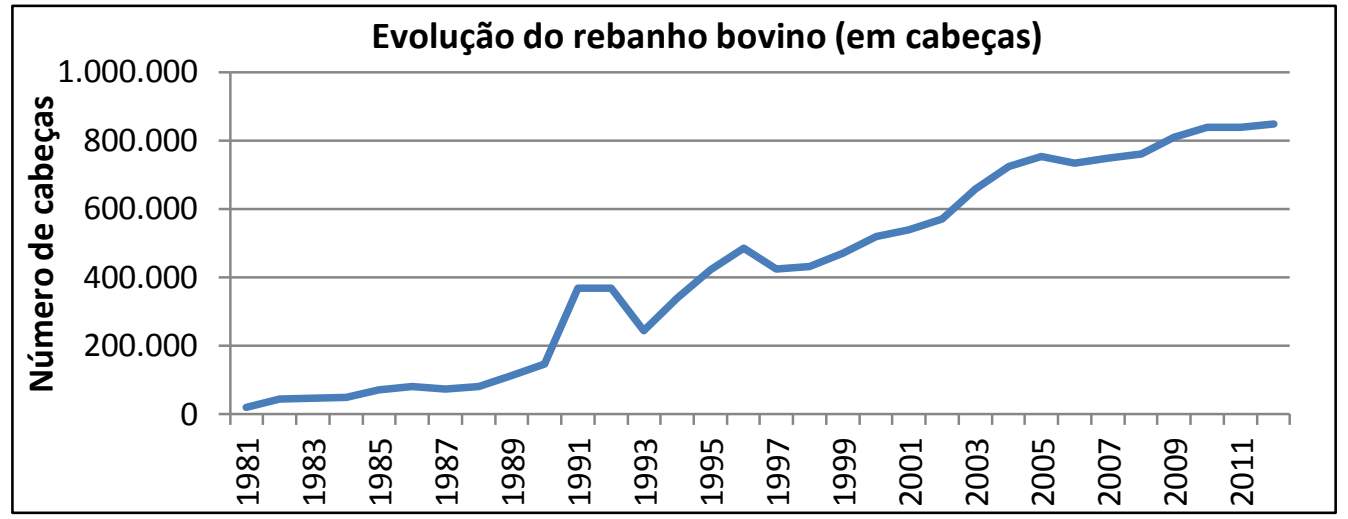

Gráfico 4 - Evolução do rebanho bovino em Alta Floresta, de 1981 a 2011. Fonte: IBGE (2014a).

${ }^{80}$ A agricultura familiar é aqui concebida como aquela atividade econômica que utiliza predominantemente mão de obra da própria família. Do ponto de vista jurídico, são consideradas unidades produtivas familiares, aqueles estabelecimentos que possuem até 4 módulos fiscais. 0 módulo fiscal é uma unidade territorial agrária fixada por cada município brasileiro baseados na Lei Federal no 6.746/79. O tamanho do módulo fiscal varia de 5 a 100 hectares, e é definido em função da qualidade dos solos, do relevo, das condições de acesso ao local etc. No município de Alta Floresta, o tamanho das propriedades, destinadas à agricultura familiar, limita-se a quatro módulos fiscais (400 hectares). 
A maior parte do rebanho destina-se à produção de carne, sobretudo para consumo local e nacional. O abate médio na área do município é entre 1.200 e 1.500 cabeças/dia (MOREIRA, 2014). Segundo dados do Ministério do Desenvolvimento, Indústria e Comércio Exterior (MDIC, 2014), a carne produzida no município ganhou o mercado internacional apenas em 2009. Hoje, são exportados mensalmente cerca de $350.000 \mathrm{~kg}$ de carne desossada e congelada, o que equivale a $2 \%$ do total da carne produzida no Estado de Mato Grosso. Os principais mercados são o Egito, Estados Unidos, Hong Kong e Angola. O principal fator responsável por este incremento da taxa de exportação é a aquisição dos frigoríficos locais por grandes redes, como a JBS (Friboi).

\subsubsection{A indústria madeireira}

Com o fim dos garimpos, em 1992, restabeleceu-se, aos poucos, a vocação agrícola da região. Contudo, a configuração fundiária já não era mais a mesma. Muitos dos pequenos lotes haviam sido adquiridos por pessoas que tinham enriquecido com a extração ou a compra-e-venda de ouro ou, ainda, com a prosperidade das fazendas de gado.

Paralelamente, a valorização do mercado da madeira, sobretudo, no Sudeste brasileiro, e possibilidade de escoamento da produção, gerada pela melhoria das estradas, possibilitou o incremento da indústria madeireira. Na percepção dos profissionais da SMS/AF, no ano 2000, existiam mais de 40 madeireiras instalaram-se na região.

Tais atividades persistem até os dias de hoje. Contudo, elas já não apresentam as mesmas configurações das primeiras fases da ocupação. $O$ setor madeireiro foi potencialmente atingido pelas fiscalizações executadas pelos Ministérios do Trabalho e do Meio Ambiente, durante a década de 2000, demandando a regularização da situação trabalhista, o aumento da segurança e o enquadramento na legislação ambiental.

Este fenômeno gerou o aumento da exportação de madeira laminada e serrada, impulsionada a partir de 2005 (gráfico 5). Atualmente a exportação de madeira está entre as principais atividades que compõem o PIB (Produto Interno Bruto) municipal ${ }^{81}$.

\footnotetext{
${ }^{81}$ Em 2006, o PIB municipal era de $\mathrm{R} \$ 389.937$ mil, composto principalmente por: $\mathrm{R} \$ 218.473$ mil (serviços), $\mathrm{R} \$ 70.743$ mil (agropecuária), $\mathrm{R} \$ 57.564$ mil (indústria) (IBGE, 2014a).
} 


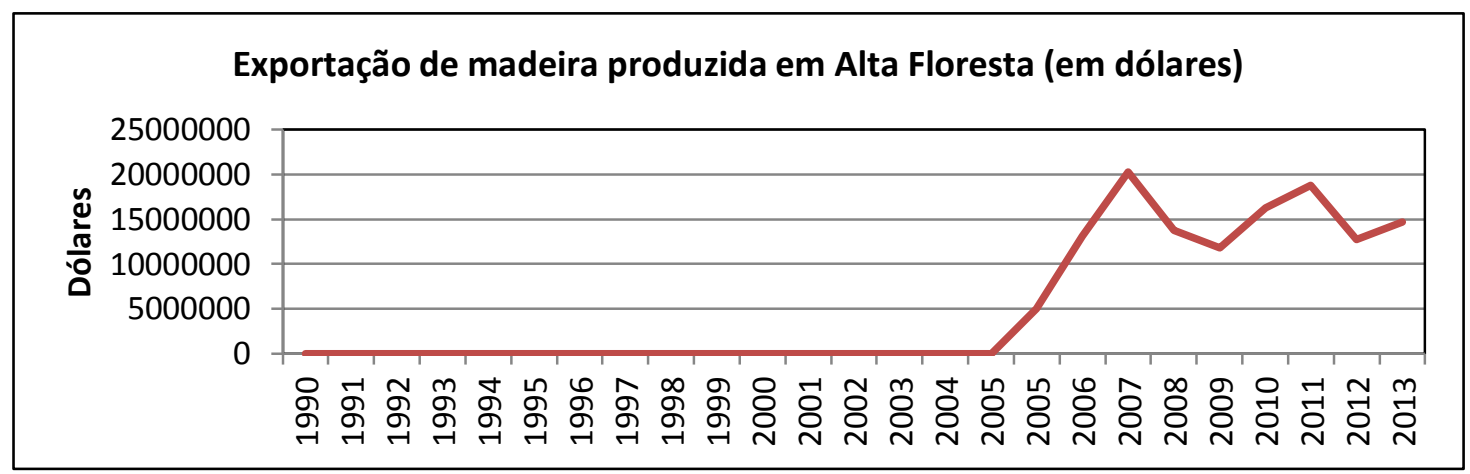

Gráfico 5 - Registro de madeira exportada, extraída em Alta Floresta, em dólares. Fonte: MDIC (2014).

\subsubsection{A chegada das grandes obras de infraestrutura e das lavouras de soja}

O potencial hidrelétrico da região vem sendo inventariado desde a década de 1980 . Contudo, apenas em 2005, com o início da implantação das obras do PAC (Programa de Aceleração do Crescimento), as construções começaram a se tornar realidade. Em 2010 iniciou-se a construção de duas (Usina Hidrelétrica Colíder ${ }^{82}$ e Usina Hidrelétrica Teles Pires ${ }^{83}$ ), de um total de cinco usinas hidrelétricas (Foz do Apiacás, São Manoel, Teles Pires, Colíder e Sinop). Elas estão localizadas nos municípios vizinhos Colíder e Paranaíta (figura 19) e afetam diretamente a dinâmica estabelecida em Alta Floresta, sobretudo no que tange à economia e demografia.

\footnotetext{
${ }^{82}$ Operado pela COPEL - Companhia Paranaense de Energia. Sua potência instalada será de 300 megawatts, o suficiente para atender ao consumo de 850 mil habitantes. A área inundada será de 182,8 km². O prazo de execução é de 2010 a 2014 (WWW.COPEL.COM/, 2015).

${ }^{83}$ Operado pelas empresas Odebrecht Energia, Voith e Alston. Sua potência instalada será de 1.820 megawatts. A área inundada será de $95 \mathrm{~km}^{2}$. O prazo de execução é de 2010 a 2014. O processo de enchimento do reservatório foi completado em janeiro de 2015 (WWW.UHETELESPIRES.COM.BR/, 2015).
} 


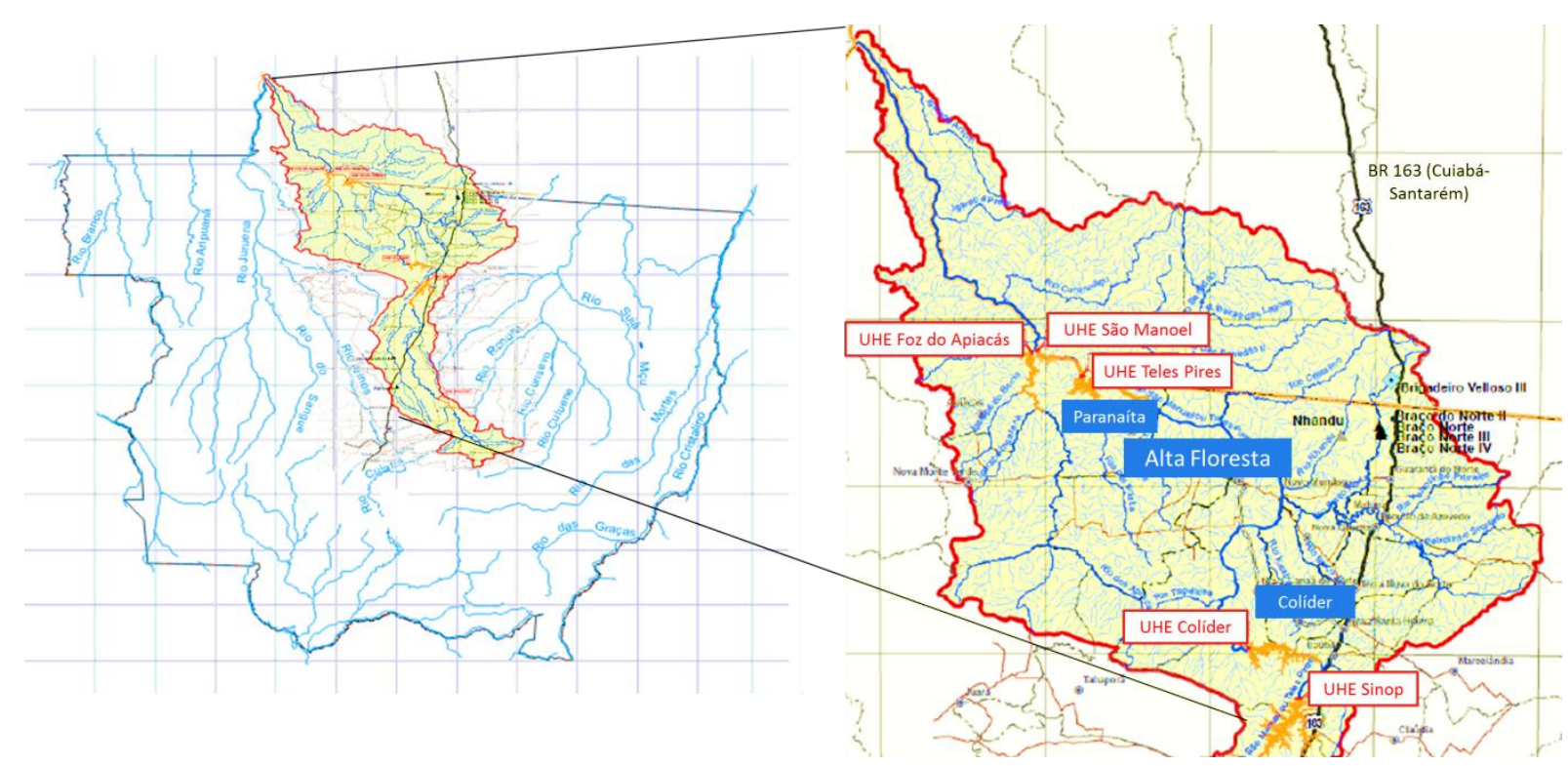

Figura 19 - Complexo hidrelétrico do rio Teles Pires. UHE = Usina Hidrelétrica. Fonte: BRASIL (2009) (com adaptações).

Além da construção das usinas hidrelétricas, especula-se que, no cenário futuro, as lavouras de soja venham a substituir grande parte da produção bovina, a qual teria como destino o confinamento.

\subsubsection{O avanço da fronteira em fases}

Em linhas gerais, o avanço da fronteira agrícola de Alta Floresta pode ser sintetizado em quatro fases. Elas apresentam a transição dos ciclos de desenvolvimento, iniciada com a produção agrícola (café, cacau, arroz, etc.) e o garimpo de ouro, e substituída, ao longo do tempo, sobretudo pela produção de carne e leite, de origem bovina, situadas em grandes (latifúndios) e pequenas propriedades (agricultura familiar). Numa perspectiva futura, cabe neste modelo (figura 20), a expansão das lavouras de soja que vem ganhado, na concepção dos quatro participantes dos quatro grupos focais, áreas do município atualmente destinadas à produção de pastagens e criação extensiva de gado.

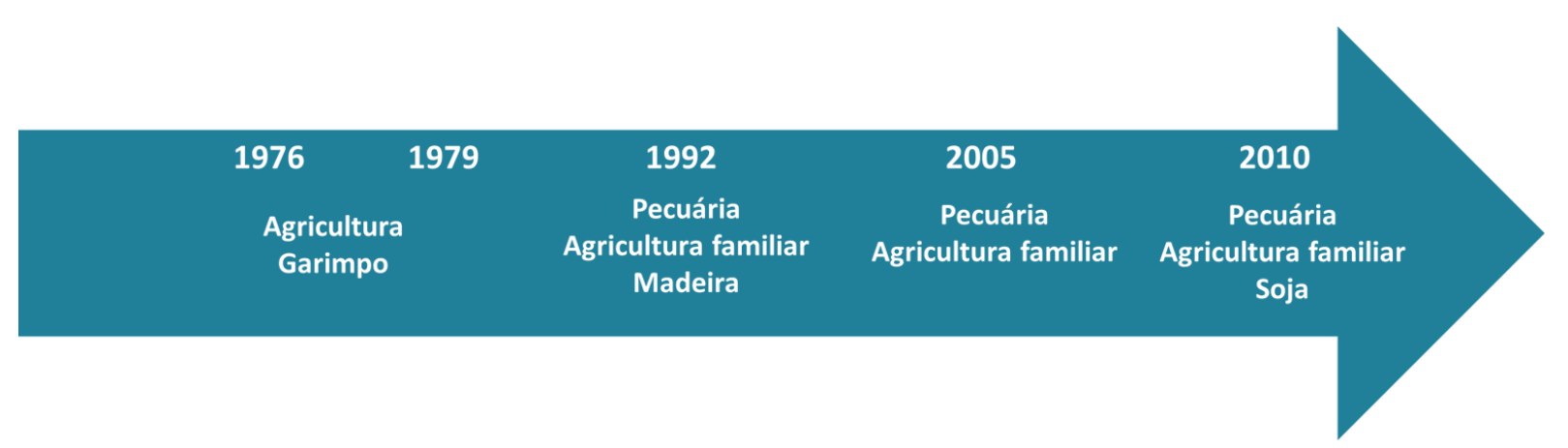

Figura 20 - Síntese do avanço da fronteira agrícola de Alta Floresta em etapas. Autoria própria. 
Esta estruturação subsidia a descrição da diferenciação das formas de adoecimento da população local, no curso do avanço da fronteira.

\section{2. $O$ avanço da fronteira e a transição das doenças: das infecções aos agravos crônicos}

Entre a chegada das primeiras famílias de agricultores à região de Alta Floresta, em 1976, aos dias de hoje, as condições de saúde se modificaram substancialmente. Sobre o período anterior à formação da fronteira pouco se comenta. Há, apenas, algumas suposições sobre a morte de indígenas por envenenamento, durante a fase de preparação da região para receber os primeiros migrantes, entre 1972 e 1976.

A figura 21 apresenta uma síntese do comportamento das doenças ao longo do avanço da fronteira. O esquema foi produzido a partir das narrativas dos participantes dos quatro grupos focais e contribui para a distinção dos principais problemas de saúde desta fronteira: a malária, as doenças respiratórias e as demais doenças crônicas, relacionadas, sobretudo, aos sistemas circulatório, cardíaco e neurológico. Além disso, o esquema tem importância em termos de identificação da dinâmica transitória das doenças. 
Acidentes (motosserras. queda de árvores e trator)

Violências Acidentes (queda de barreira e afogamento)

Malária $\quad$ Violências

Leishmaniose tegumentar americana

Mortalidade infantil

HIV

\begin{tabular}{lll} 
& Hepatites e outras DSTs & Dengue \\
Verminoses & Hanseníase \\
\hline Blastomicose &
\end{tabular}

Blastomicose

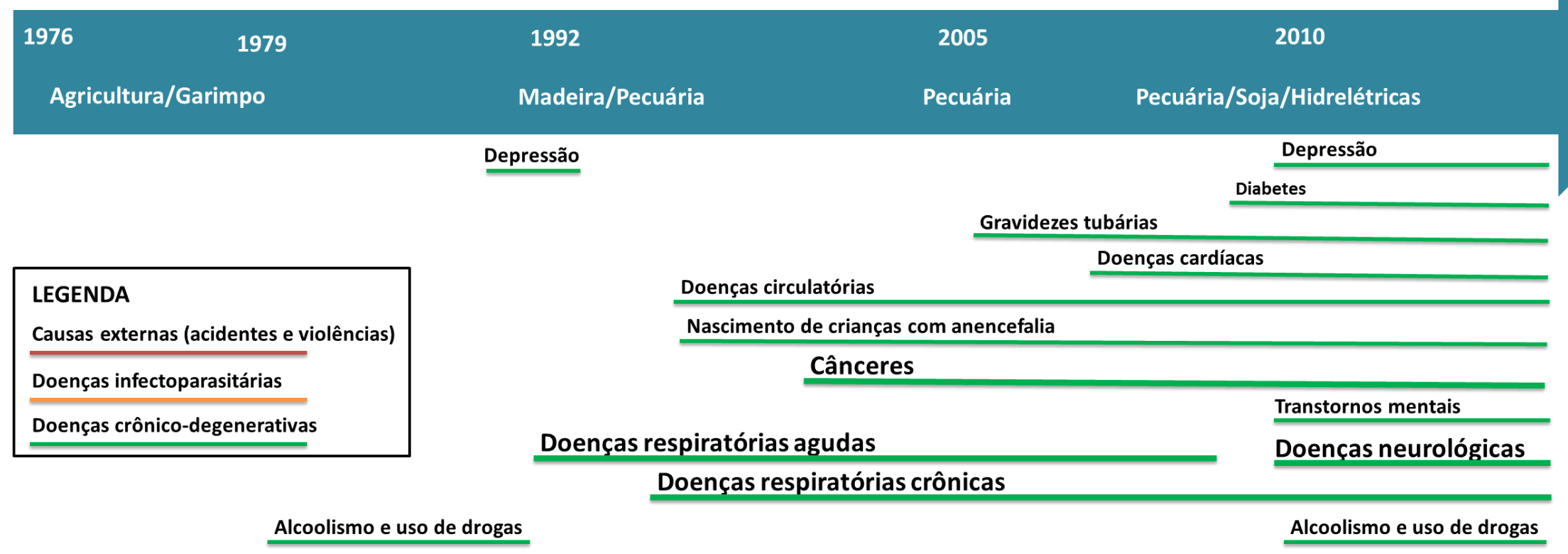

Figura 21 - Linha histórica das doenças na fronteira agrícola de Alta Floresta. Autoria própria. Fonte: Pesquisa de campo, março de 2013. 
Na fase I, de predominância da agricultura e da mineração de ouro, são encontrados os problemas mais representativos em termos de saúde. De um lado, uma alta prevalência de verminoses e de mortalidade infantil, associadas à pobreza e à insalubridade. De outro, uma série de agravos, provocados por acidentes e violências (lesões, traumas físicos e mortes), e um conjunto de doenças infectoparasitárias, relacionadas ao ecossistema amazônico (malária, leishmaniose tegumentar americana) ou aos garimpos de ouro (hepatites virais e DSTs - Doenças sexualmente transmissíveis ${ }^{84}$ ).

No que se refere ao trabalho agrícola nota-se a importância dos acidentes de trabalho associados à derrubada da floresta. Eles deviam-se, em grande medida, à negligência dos fatores de risco e à deficiência em relação ao uso de equipamentos de proteção individual (EPIs). Trata-se de uma situação que foi definida, sobretudo, pela falta de conhecimento e experiência com o uso de equipamentos, como, por exemplo, motosserras e tratores. Em última instância, ela resultava da escassa orientação e fiscalização das condições de trabalho.

Nos garimpos, sobressaiam-se os casos de acidentes provocados por "queda de barreira" e afogamento. Estes incidentes eram gerados, de maneira geral, pela forma com que executava a extração do minério. A garimpagem se dava principalmente às margens de rios e igarapés. O substrato presente nestas margens era escavado com o auxílio de uma bomba d'água (draga). À medida que a draga aprofundava na superfície, formavam-se barrancos de terra. Com certa frequência, estas barreiras desabavam sobre os trabalhadores provocando afogamentos, traumas físicos e, inclusive, lesões fatais.

Outras centenas de trabalhadores dos garimpos sucumbiram na grande epidemia de malária que ganhou força nesse período. A infecção malárica foi introduzida na região pelos próprios garimpeiros (BARBIERI, 2007). Eles vinham infectados com o agente da doença das suas regiões de origem, principalmente os Estados do Norte do país. Na chegada em Alta Floresta, tornavam-se disseminadores da infecção após serem picados pelo mosquito transmissor. A ampla distribuição de mosquitos veiculava a doença em todas as áreas, atingindo praticamente todas as pessoas. Na percepção dos agricultores, na fase forte da epidemia, entre 1987 e 1992, cerca de nove entre cada dez habitantes locais desenvolveram a doença.

A eliminação da epidemia de malária coincidiu com o fechamento dos garimpos, no ano de 1992. Nessa nova fase, ao tempo em que a madeira e a pecuária extensiva se tornavam as principais atividades econômicas, ganhavam relevância as doenças respiratórias agudas e crônicas. Elas foram atribuídas a dois fatores: (i) o aumento da

\footnotetext{
${ }^{84}$ Doenças como gonorreia e sífilis, entre outras.
} 
poluição atmosférica, provocada pelas queimadas florestais e de pastagens e, em menor proporção, (ii) a mobilização de fungos presentes no solo, causadores da blastomicose ${ }^{85}$, uma doença pulmonar que acomete principalmente agricultores e trabalhadores rurais.

Embora os agravos respiratórios crônicos persistam até os dias atuais, as formas agudas da doença foram parcialmente reduzidas no final da década de 2000. Esta diminuição coincidiu com o fortalecimento das ações de controle do desmatamento e das queimadas, impulsionado pelo governo federal, a partir de 2005. Em Alta Floresta, essas ações geraram o fechamento da grande parte das madeireiras e o aumento da preocupação do administrativo municipal e dos produtores agropecuários com a regularização ambiental. Nesse cenário, observa-se uma expressiva redução da taxa das queimadas.

Além das doenças respiratórias, os anos 1990 foram marcados pelo aumento do número de casos esporádicos de nascimento de crianças com anencefalia (ausência de cérebro) e de gravidez tubária (geração extrauterina de embriões). Em linhas gerais, suspeita-se, na região, que a emergência destas doenças esteja associada à contaminação ambiental por mercúrio, deixada pelos garimpos, e por agrotóxicos (do tipo DDT e BHC), usados na produção de café, arroz e pastagens, bem como no controle dos mosquitos transmissores da malária.

Também são dessa época, as primeiras manifestações de hanseníase, dengue e AIDS (Síndrome da Imunodeficiência Adquirida). Tais doenças se instalaram na região e, até hoje, concorrem como as infecções de maior importância em termos de saúde pública. De forma geral, o recrudescimento ou a emergência dessas doenças infecciosas, no período recente, obedece a uma tendência nacional. Somente a hanseníase se apresenta como um problema mais particular da Amazônia. A dinâmica desta doença é atribuída, sobretudo, à vulnerabilidade social, sustentada pelo reduzido nível de escolaridade, a pobreza e as restrições do acesso a serviços de saneamento e saúde. Adicionalmente, verifica-se uma ligeira associação entre a sua manifestação e alguns fatores típicos da ocupação das fronteiras agrícolas, como a alta mobilidade populacional e a criação de ambientes favoráveis à sua disseminação, a partir do desmatamento e da urbanização (SILVA et al., 2010). A tendência da hanseníase na região, segundo informações de campo, é estabilizarse, em razão do maior acesso à informação e ao conhecimento sobre e doença, principalmente porque grande parte da população já foi infectada e tratada.

No quadro recente se radicam as doenças crônicas. Nesta perspectiva, são cada vez mais comuns, os casos de "pressão alta" (hipertensão arterial), os "derrames cerebrais"

${ }^{85}$ Ela é causada pelos esporos do fungo da espécie Paracoccidioides brasiliensis, por isso ela também é conhecida como paracoccidioidomicose. Estes esporos são removidos do solo pelo uso de enxadas, arados ou outros equipamentos de uso agrícola. Na sequencia, misturam-se ao ar e são inalados pelo trabalhador. A doença acomete principalmente agricultores e trabalhadores rurais. 
(AVCs), os infartos cardíacos e a "doença do coração grande" (cardiomiopatia dilatada ${ }^{86}$ ). Estas enfermidades pertencem ao conjunto de doenças denominado cardiovascular, a principal causa de morte no Brasil e no mundo.

Outras doenças crônicas relacionadas ao período mais recente são os diversos tipos de câncer, as diabetes, os transtornos mentais (esquizofrenia), as depressões e as doenças neurológicas (mal de Parkinson e doença de Alzheimer). Tais doenças se manifestam, sobretudo, entre agricultores e filhos de agricultores (que formam a grande maioria da população local).

O período atual é marcado, além do que já foi mencionado, pelo aumento dos diferentes tipos de violências físicas ${ }^{87}$ e dos acidentes de trânsito. Em termos gerais, esta multiplicação das "causas externas" é associada ao aumento populacional ${ }^{88}$ dos últimos anos, provocado pela entrada de trabalhadores para a construção da usina hidrelétrica do Teles Pires. Coopera, com este quadro, a proliferação do uso de motocicletas, o meio de transporte adotado por uma parte significativa da população, face à ausência de transporte coletivo no município e as facilidades de aquisição do veículo (por financiamentos e consórcios).

Em síntese, observa-se que entre as doenças de maior importância em termos de quantidade de pessoas afetadas e gravidade dos danos à saúde destacam-se: (i) a malária, devido à grande epidemia que acometeu a maior parte da população entre os anos $1980 \mathrm{e}$ 1990, (ii) as doenças respiratórias, que se diferenciam ao longo do tempo, passando de uma fase em que predominaram as formas agudas (anos 1990 e início dos anos 2000), para uma fase em que aumentou a prevalência das formas crônicas (a partir do final dos anos 1990), e (iii) as demais doenças crônicas de efeito, preponderantemente, cardiovascular e neurológico (na fase atual).

\subsection{A trajetória do Sistema de Saúde}

Uma das características dos projetos agrícolas privados, como o de Alta Floresta, era o domínio das empresas colonizadoras sobre todas as dimensões do desenvolvimento, principalmente durante as primeiras fases da ocupação. Estes fatores limitavam a

\footnotetext{
${ }^{86}$ Aumento do volume do coração causado pelo comprometimento do ventrículo esquerdo. Tem como causa: fatores genéticos, defeitos congênitos, infecções (vírus, fungos, parasitas ou bactérias), doenças autoimunes (febre reumática, por exemplo), consumo de álcool e medicamentos e exposição a metais pesados, como chumbo, mercúrio e cobalto.

${ }_{87}$ Atualmente são registrados, em média, 1,5 casos diários de internação provocados por lesões, envenenamentos e algumas outras consequências de causas externas. A principal causa tem sido os acidentes que envolvem motocicletas (MATO GROSSO, 2014).

${ }^{88}$ Mais de quatro mil trabalhadores migraram para a região para atuar na construção da usina.
} 
participação do Estado e desenhavam uma lógica privada de gestão (MIRANDA, 1990). Neste contexto, o acesso da população a serviços públicos foi limitado àqueles que possuíam condições financeiras para pagar pelas consultas médicas e pelo tratamento farmacêutico. No caso de Alta Floresta, até mesmo nas situações em que o acesso aos serviços públicos existia, como no caso das escolas públicas, a orientação e o controle das atividades se mantinha nas mãos da INDECO (ROCHA, 2008).

Estes fatores tiveram forte influência sobre a constituição dos serviços de saúde. $O$ primeiro hospital público de Alta Floresta só foi inaugurado no ano de 1993, dezessete anos após a ocupação inicial da região. Antes disso, os serviços médicos eram prestados por hospitais privados. Os únicos serviços públicos eram a vigilância ${ }^{89}$ de doenças infecciosas e a vacinação, realizada pela extinta SUCAM, e as ações da Atenção Básica (vacinação e prevenção e promoção da saúde), sobretudo no que se refere à saúde infantil, desenvolvidas por um posto de saúde, vinculado ao, então, INAMPS (Instituto Nacional de Assistência Médica da Previdência Social) ${ }^{90}$ (atual SUS - Sistema Único de Saúde).

Em termos de atendimento à saúde, alguns contrassensos marcaram essa época. Em primeiro lugar, a qualidade dos serviços. Segundo os profissionais da SMS/AF e da $\mathrm{SMS} / \mathrm{PT}$, a formação das equipes técnicas de enfermagem era elementar, o que comprometia, em partes, os resultados dos tratamentos. Mas, paradoxalmente, conta-se que o trabalho dos médicos no tratamento da malária e no atendimento de pessoas baleadas ou esfaqueadas em conflitos apresentava resultados consideravelmente superiores aos encontrados em outras regiões do país. Para os profissionais do ERS/AF, os médicos haviam se especializado em razão do grande número de atendimentos, principalmente, da malária. As pessoas que saiam da cidade, para procurar tratamento em outras regiões do país, como nos Estados do Paraná e de São Paulo, poucas vezes sobreviviam, devido a demoras no diagnóstico e no tratamento das doenças.

\subsubsection{A SUCAM, as doenças infectoparasitárias e os equívocos de abordagem}

A SUCAM teve um papel primordial na minimização dos danos provocados pelas doenças infectoparasitárias. No entanto, alguns equívocos, em termos de prioridade e abordagem, bem como a baixa quantidade de servidores, trouxeram significativos prejuízos

\footnotetext{
${ }^{89}$ Vigilância, na área da saúde, significa a observação e análise permanente da situação de saúde de uma população.

${ }^{90}$ Naquele período, a estrutura do sistema nacional de saúde se fundamentava no INAMPS. Tratavase de uma autarquia federal que prestava atendimento médico aos contribuintes da previdência social, ou seja, aos empregados de carteira assinada, uma categoria praticamente inexistente na fronteira agrícola daquela época. Além disso, era bastante restrito o acesso ao Programa de Assistência Rural (PRORURAL), que previa a assistência à saúde dos trabalhadores rurais, durante o governo militar.
} 
ao controle das doenças. Em primeiro lugar, os profissionais da FUNASA citaram o investimento na vacinação de toda a população contra a febre amarela. Esta foi uma medida importante para impedir que a doença se disseminasse pela região. No entanto, diante da prioridade dada à febre amarela, o risco para a malária foi secundarizado. Assim, quando o agente desta doença foi introduzido na região, os agricultores não possuíam o conhecimento para reconhecê-la, o que resultou em vários casos de adoecimento ou morte. "As pessoas do Sul confundiam a doença com uma gripe forte", comentou-se no grupo focal realizado no Bairro Vila Nova.

Outro equívoco da SUCAM esteve relacionado à medida escolhida para o controle da malária. Optou-se pela distribuição e aplicação de inseticidas, como o DDT e o BHC. Eles eram oferecidos às famílias de agricultores para o uso doméstico. Ademais, realizavam-se pulverizações na zona urbana com uso de um veículo, conhecido como "fumacê". Depois de mais de uma década de uso contínuo destas substâncias, os resultados ainda estavam bastante aquém das expectativas. Só então se concluiu que, além do uso de pesticidas significar um problema maior ao sistema de saúde, devido às intoxicações e as possíveis consequências futuras, ele não era suficiente para o controle da doença. As pulverizações não conseguiam eliminar o mosquito, que se multiplica no ambiente natural.

Também a baixa capacidade de atendimento aos doentes, em virtude do pequeno número de servidores, prejudicava os resultados do trabalho da SUCAM. Quando a instituição foi instalada na região, no ano de 1976, ela contava com apenas dois funcionários. A eles cabia a vacinação contra a febre amarela, como já foi comentado, e a vigilância de todos os imóveis, rurais e urbanos, centrada no controle da leishmaniose e na eliminação de insetos. Com a explosão da epidemia de malária, a instituição passou a cobrir, também, o diagnóstico ${ }^{91}$ da malária, o tratamento dos doentes e a distribuição de medicamentos nas localidades de maior incidência da doença, como os garimpos. A abrangência das ações da instituição, face à grandeza que ganhou a epidemia da malária, se tornou incipiente.

Nesse entremeio, surgiram algumas outras formas de atendimento à saúde. Havia, segundo relatos dos profissionais da SMS/PT, uma forte presença de benzedeiros. Além disso, disseminou-se uma técnica alternativa de diagnóstico e terapêutica, conhecida como "bioenergético" ou "araminho". Conta-se que, preocupada com a alta prevalência de doenças como a malária, a leishmaniose e a tuberculose, a Igreja Católica ofereceu cursos de formação de agricultores com o objetivo de disseminar esta técnica. Na prática, as doenças eram diagnosticadas com base no "equilíbrio energético do corpo", que era

\footnotetext{
${ }^{91}$ O diagnóstico era realizado por meio da coleta de sangue, confecção de lâminas e visualização das amostras em microscópio.
} 
verificado por uma dupla de pessoas, usando um arame (por isso o nome "araminho") e um manual de referência de doenças. Para o tratamento era sugerida uma combinação de várias plantas medicinais.

Os profissionais da FUNASA citaram que, diante do caos que se instalou na saúde pública, devido à epidemia de malária, uma das alternativas encontradas pela instituição foi o treinamento dos casais que praticavam o "araminho", para participar da vigilância da infecção. Eles eram preparados para disseminar medidas de controle e cuidados com os mosquitos e coletar sangue, para o diagnóstico das pessoas que apresentavam quaisquer sintomas da doença.

Sob o ponto de vista do sistema de saúde, os tratamentos se baseavam na ingestão de comprimidos de Quinino ${ }^{92}$ e Cloroquina ou Aralen ${ }^{93}$, entre outros. Esses medicamentos eram distribuídos gratuitamente pela SUCAM. Grandes quantidades eram levadas às zonas de garimpo e entregues a uma pessoa, escolhido para administrá-los àqueles que apresentassem algum sintoma da malária. Um dos profissionais da FUNASA contou que os garimpeiros ingeriam o medicamento mesmo sem apresentar qualquer indício da infecção. O objetivo do uso antecipado do remédio era prevenir-se contra a doença.

Nos primeiros anos da década de 1990, o sistema público de saúde brasileiro organizou uma ampla campanha de controle da malária na região amazônica. Esta campanha tinha um diferencial: o controle da epidemia a partir do tratamento dos doentes, ao invés do combate aos mosquitos. Estas medidas integravam um Projeto de Controle da Malária na Bacia Amazônica (PCMAM), financiado por instituições internacionais ${ }^{94}$ e desenvolvido com o objetivo de estruturar os serviços locais de saúde, principalmente quanto à capacidade de diagnóstico e tratamento dos doentes (LOIOLA; MANGABEIRA DA SILVA; TAUIL, 2002).

Em 1993, quando o hospital público local foi inaugurado, grande parte dos garimpeiros já havia emigrado para outras regiões e o controle da malária já estava numa fase bastante avançada. O hospital se tornou importante, no entanto, por aumentar o acesso ao tratamento das doenças infectoparasitárias (verminoses, hepatites, tuberculose, leishmaniose e blastomicose) e das lesões traumáticas, provocadas por acidentes e violências. Estas, contudo, não foram as principais responsáveis pela internação, mas, sim,

\footnotetext{
${ }^{92}$ Composto de origem natural, extraído da quina (Cinchona sp), uma árvore originária da América do Sul, encontrada na Amazônia. A planta vem sendo amplamente usada de forma medicinal desde a sua descoberta no Império Inca, final do século XVI e início do século XVII. Os Incas a usavam para curar febre.

${ }^{93}$ Composto de origem sintética distribuído pelo sistema de saúde a partir da década de 1980 para o tratamento da malária.

${ }_{94}$ Banco Mundial e Banco Internacional de Reconstrução e Desenvolvimento (BIRD).
} 
as doenças do trato respiratório, um dos principais problemas de saúde dos anos 1990 e 2000.

\subsubsection{Um novo modelo para a saúde: avanços e limites do SUS em Alta Floresta}

Com a Constituição de 1988, o sistema de saúde brasileiro foi ampliado e ganhou nova abordagem. Os cidadãos brasileiros passaram a ter a saúde como direito universal, que deveria ser cumprido de forma integral, incluindo desde a promoção da saúde, à prevenção de riscos e agravos e a assistência a doentes (tratamento e cura). Em Alta Floresta, este novo enfoque só chegou depois de 1998, quando se iniciou a implementação dos postos do PSF (Programa Saúde da Família ${ }^{95}$ ) e foram contratados os primeiros agentes comunitários de saúde ${ }^{96}$. Consequentemente, o novo conjunto de serviços, ofertado pelo Hospital Municipal, os postos de saúde e a SUCAM (já em processo de transformação para FUNASA), passou a ter maior influência em termos de controle das doenças, sobretudo as infectoparasitárias.

$\mathrm{Na}$ década de 2000, foi instalado, no município, o escritório regional do Alto Tapajós, vinculado à Secretaria de Estado de Saúde. Esta repartição passou a ter papel relevante no controle dos gastos públicos e da qualidade dos serviços, bem como, no domínio das notificações das doenças. Paralelamente, ganhou folego a cobertura das equipes dos PSFs, baseada nas atividades da Atenção Básica, a porta de entrada do SUS, para resolver os problemas de saúde mais frequentes entre a população. Também foram fortalecidas as ações de vigilância epidemiológica centradas no controle de vetores de doenças como a leishmaniose e a dengue. Neste contexto, foi possível controlar uma boa parte dos problemas de saúde que se arrastavam desde a primeira fase da ocupação da região, principalmente a mortalidade infantil, as DSTs e as verminoses.

\footnotetext{
${ }^{95}$ Postos vinculados à Estratégia Saúde da Família, vinculados ao Ministério da Saúde. Esta estratégia tem como objetivo reorientar o modelo assistencial (hospitalocêntrico) da saúde, para que possa assumir perspectivas da atenção básica (vigilância, prevenção e promoção da saúde). $\mathrm{Na}$ prática, executam-se ações orientadas pelo atendimento integral e contínuo de um conjunto de famílias de acordo com problemas identificados em seu território (bairro, setor, vila, comunidade, etc.). Essas ações são fundamentadas pela promoção, proteção e recuperação da saúde e são desenvolvidas por uma equipe multiprofissional (médico da família, enfermeiros, dentistas, psicólogos, educadores físicos, etc.), que tem como sede fixa um posto de saúde. Elas também são executadas por agentes comunitários de saúde, que são profissionais da própria comunidade, preparados para atuar na vigilância da saúde, realizada por meio de visitas residenciais mensais.

${ }_{96}$ Agentes comunitários de saúde são profissionais que atuam em um território definido coletando informações das condições de saúde, acompanhando os casos de doenças crônicas (diabetes, hipertensão, etc.) e infectocontagiosas (tuberculose, hanseníase, etc.), vigilando a vacinação e controlando as endemias.
} 
Atualmente, o município possui um hospital público e quatro hospitais privados, de média complexidade ${ }^{97}$. São, ao todo, 87 leitos hospitalares conveniados ao SUS (um leito para cada 565 habitantes). Além disso, a rede de serviços públicos de saúde se estrutura por meio de 13 unidades básicas de saúde, 11 delas orientadas pela Estratégia Saúde da Família (cobrindo 64\% da população total) (CARMO et al., 2009). Não existem leitos de Unidade de Tratamento Intensivo (UTI) no município. Também não há Serviço de Atendimento Móvel de Urgência (SAMU), mas o município participa do Sistema Integrado de Atendimento ao Trauma (SIAT), operacionalizado pelo Corpo de Bombeiros, que oferece serviços similares ao do SAMU (VENITES, 2009).

Apesar das conquistas recentes, o sistema de saúde local ainda enfrenta importantes problemas relacionados ao acesso e à qualidade dos serviços, sobretudo no âmbito hospitalar. Os participantes dos grupos focais citaram, repetidamente, a falta de infraestrutura e de médicos. Além disso, aborda-se o problema da própria formação médica. Segundo um dos servidores do ERS/AF, a classe médica nem sempre contribui para os avanços do sistema, devido à "falta de sensibilidade em relação à prevenção e promoção da saúde".

O quadro atual é, portanto, de um sistema estruturado em termos de atenção básica, o que vem contribuindo, de forma considerável, para o controle de algumas doenças como a tuberculose e a hanseníase (a partir do acompanhamento dos pacientes), e para a vigilância de outras, como a hipertensão arterial e diabetes (por meio da sensibilização para a mudança de hábitos).

Sob o ponto de vista médico-hospitalar também há ganhos importantes, segundo os participantes dos grupos focais, sobretudo no que diz respeito ao aumento da complexidade dos serviços. Contudo, também neste aspecto, preocupam algumas questões como a dificuldade de acesso ao sistema (grandes filas de espera nos hospitais) e baixa qualidade dos serviços, entre outros. Além disso, reconhece-se, por exemplo, a inexistência de atendimentos específicos de psicoses e de tratamentos a agravos como os cânceres e as doenças neurodegenerativas (mal de Alzheimer e doença de Parkinson). Nestes casos, os doentes são, ou negligenciados (psicoses), ou são obrigados a buscar apoio em centros

\footnotetext{
${ }^{97}$ A organização da prestação da assistência no SUS é baseada em dois blocos: (i) a atenção básica, que abrange a promoção e a proteção da saúde, a prevenção de agravos, o diagnóstico, o tratamento, a reabilitação, a redução de danos e a manutenção da saúde, mas emprega tecnologia de baixa densidade (BRASIL, 2012) e (ii) as ações de média e alta complexidade ambulatorial e hospitalar, que integra procedimentos especializados realizados por profissionais médicos, outros profissionais de nível superior e nível médio (BRASIL, 2007b).
} 
maiores $^{98}$, como em Cuiabá ou em cidades do Estado do Paraná (doenças neurodegenerativas) e, ainda, em Barretos, interior de São Paulo (cânceres).

\section{Conclusão}

A descrição apresentada neste capítulo alimenta a afirmação de que o perfil epidemiológico de Alta Floresta sofreu mudanças significativas ao longo do avanço da ocupação da região. Esta transformação está relacionada, em primeira instância, à melhoria da infraestrutura local, sobretudo no que diz respeito ao setor saúde. A partir da constituição de equipes de trabalho e a instalação de estruturas de apoio, foi possível reduzir a prevalência da maior parte das doenças infectoparasitárias. Este resultado incidiu de forma mais significativa sobre a prevalência da malária.

Verifica-se, contudo, que a redução da incidência das doenças infectoparasitárias não significou a efetiva melhoria das condições de saúde da população local. Assim como ocorreu nas fronteiras da maior parte do mundo, à medida que a ocupação desta região foi avançando, a população passou a ser acometida também pelas doenças crônicas.

A tendência atual é de redução das doenças infectoparasitárias e o incremento das doenças crônicas. Que fatores produzem a emergência destes dois grupos de doenças? Que relação existe entre a emergência das doenças e as formas de ocupação do espaço? As alterações no meio ambiente, efetivadas durante este processo, estão entre os potenciais responsáveis por este processo. Estes resultados são apresentados no próximo capítulo.

\footnotetext{
${ }^{98}$ Esta migração de doentes para outros centros médicos, em busca de tratamento, distorce, em grande medida, a notificação das doenças. Para serem atendidos naquelas localidades, eles precisam, muitas vezes, comprovar residência e, assim, os casos acabam sendo notificados como pertencentes àqueles territórios da saúde.
} 


\section{Capítulo 8. DEGRADAÇÃO BIOFíSICA DO MEIO AMBIENTE E RISCOS À SAÚDE NO CONTEXTO DA FRONTEIRA AGRÍCOLA DE ALTA FLORESTA: DOENÇAS INFECTOPARASITÁRIAS}

\section{Introdução}

No capítulo anterior, descrevemos o histórico do uso e ocupação agrícola do espaço em paralelo ao percurso da saúde pública. Esta abordagem nos mostrou algumas similaridades entre o avanço da ocupação agrícola e a transição das doenças (de infectoparasitárias para crônicas). Nesta seção, apresentamos a trajetória das transformações do meio ambiente, tendo como objetivo destacar o elo entre a degradação biofísica e as doenças infecciosas, com prioridade ao comportamento da malária. Esta é a primeira parte da discussão sobre a relação meio ambiente e saúde. A análise dos riscos produzidos pela contaminação tóxica é realizada no próximo capítulo.

Assim como no capítulo anterior, também aqui o texto está ancorado em diagramas, falas e narrativas. Em complemento, subsidiam a discussão, resultados de pesquisas científicas de diferentes áreas, desenvolvidas na região de estudo.

\subsection{O avanço da ocupação e a degradação biofísica do meio ambiente}

\subsubsection{Desmatamento}

A chegada das famílias de agricultores, a partir do ano de 1976, impulsionou a derrubada de uma parcela importante da floresta, que deu lugar à rodovia MT-208 e as estradas vicinais, que ligavam a cidade de Alta Floresta às propriedades rurais. Além disso, a abertura da floresta também esteve relacionada à construção da cidade e à formação das lavouras agrícolas. Neste primeiro momento, predominou a produção de café e cacau, entre outras culturas perenes. Numa fase subsequente, ganharam importância as plantações de arroz, feijão e milho.

Segundo um dos servidores da SMS/AF, nesta fase, a derrubada da floresta não respeitava quaisquer limites. Ao contrário, "os proprietários de terras tinham instruções da colonizadora para abrir $50 \%$, senão, havia ameaças de perda da propriedade. Depois de aberta esta parte, os proprietários deixavam o fogo entrar nos outros $50 \%$ e derrubavam tudo". 
No entanto, o primeiro impulso econômico, diretamente relacionado à dinâmica do desmatamento, não se perpetuou nos primeiros anos. As dificuldades econômicas encontradas pelos produtores rurais, diante de uma série de problemas relacionados à produção, transporte e comercialização, em um contexto de crise econômica nacional vivenciada nos anos 1980 resultaram no endividamento de uma grande maioria. Neste cenário, a migração para os garimpos de ouro, abertos no final da década de 1970, reduziu os investimentos na agricultura e influenciou, em última instância, a queda do ritmo do desmatamento.

Contudo, o fechamento dos garimpos, em 1992, fez o desmatamento voltar a crescer. Até então a ocupação agrícola havia consumido cerca de 200 mil hectares de mata, significando aproximadamente $25 \%$ do território municipal (SOUZA, 2006).

Em grande parte dos casos, o impulso para a abertura das áreas, nesta segunda fase, era dado pelas empresas madeireiras, que se multiplicaram a partir do final dos anos 1980 . A madeira de maior valor econômico era comprada dos agricultores a preços irrisórios. Ela era retirada da mata com a ajuda de tratores, caminhões e motosserras (CASTRO et al., 2008). Desta forma, numerosas estradas e picadas foram abertas no interior da mata, de onde a madeira era extraída de forma predatória, sem planejamento de exploração ou autorização. Raras vezes a ação das madeireiras sofria algum tipo de fiscalização ambiental.

Grosso modo, após a fase de exploração madeireira, as áreas foram abertas para a formação de pastagens, destinadas à criação extensiva de gado de corte e leite. Restam, hoje, menos de 400 mil hectares de floresta, o que representa menos de $50 \%$ do território municipal (INPE, 2014a) (gráfico 6). Deste total, pelo menos 285 mil hectares são destinados à pastagem, sustentando um efetivo bovino de mais de 800 mil cabeças (IBGE, 2006). 


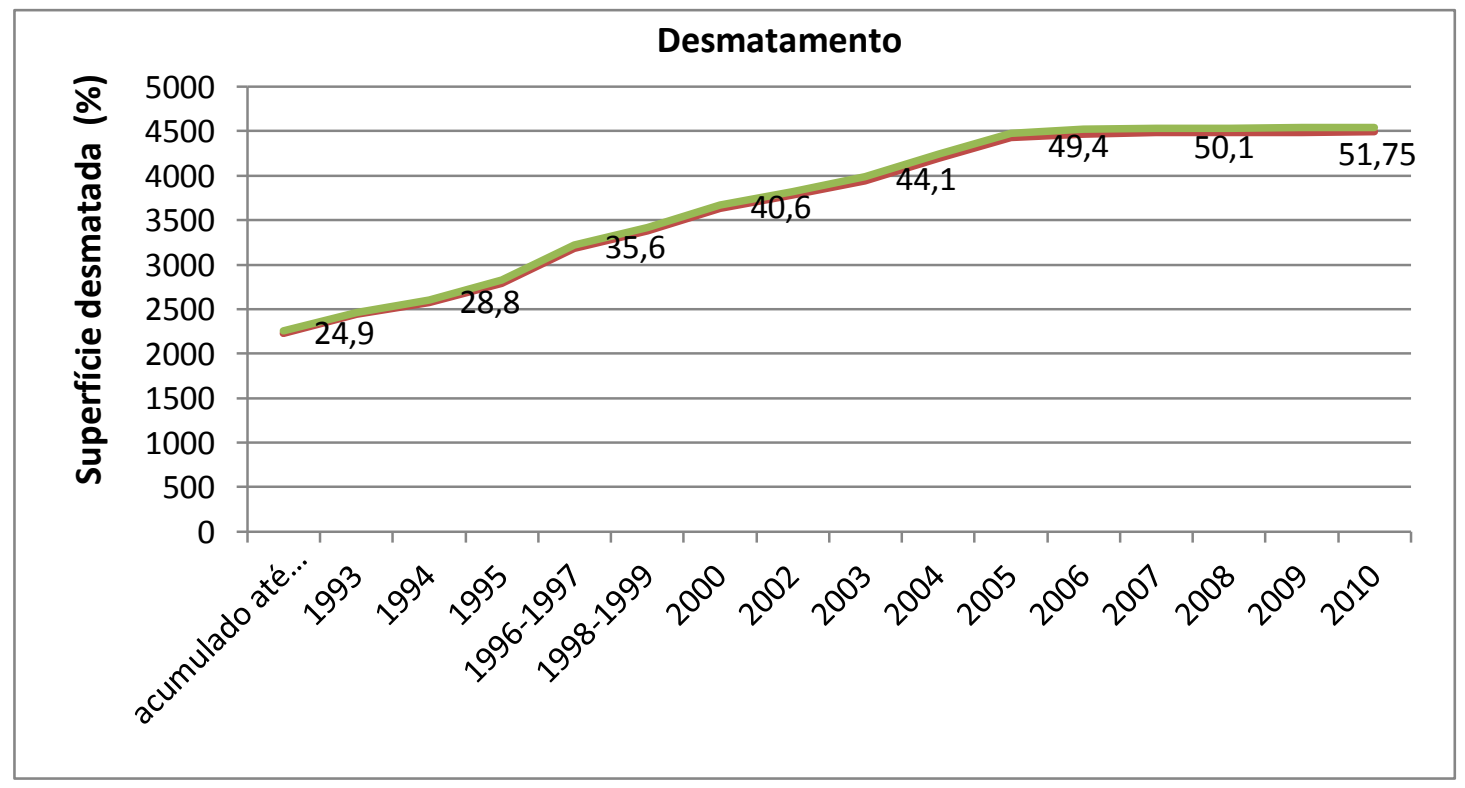

Gráfico 6 - Acumulado do desmatamento até 2010, elaborado a partir de dados da SEMA e do PRODES/INPE (Programa de Cálculo do Desflorestamento da Amazônia/Instituto Nacional de Pesquisas Espaciais). Fonte: Souza (2006) e INPE (2014).

\subsubsection{Queimadas}

$\mathrm{Na}$ atividade pecuária, seguiram-se reproduzindo formas de degradação similares às da fase de formação das áreas de plantio. A vegetação era derrubada com uso de uma corrente de navio, atracada a dois tratores esteiras. Na medida em que os tratores avançavam, a corrente derrubava toda a vegetação. Concluída a derrubada, faziam-se aceiros, para impedir propagação de incêndios para outras propriedades, e ateava-se fogo. De forma geral, pouco ou quase nada da madeira era aproveitada.

Além da queima da biomassa florestal, o fogo também foi usado para a prática de limpeza e renovação das áreas de pastagem. Neste caso, os produtores ateavam fogo na sua própria propriedade durante a estação seca com objetivo de reduzir as ervas invasoras, incluindo algumas plantas venenosas, e de provocar o rápido rebrotamento do capim. Em alguns casos, os produtores perdiam o controle do fogo, que acabava invadindo outras propriedades ou a floresta remanescente, gerando extensos incêndios. Em outros casos, comenta-se que a prática era utilizada como estratégia para aumentar a área de pastagem, sem que fosse preciso desmatar. Esse comportamento despistava, segundo os participantes da pesquisa, a atenção dos órgãos ambientais.

O acumulado da passagem do fogo pelas florestas foi o principal responsável pela atual degradação de cerca de $20 \%$ das áreas adjacentes às pastagens, algo como 170 mil hectares de cobertura vegetal (BERNASCONI; ADAB; MICOL, 2008). Além disso, o fogo 
também foi responsável pela degradação da vegetação e do solo que protege as nascentes hidrográficas. Neste contexto, estima-se que mais de $50 \%$ das nascentes de cerca de seis mil, existentes no território municipal, estejam degradadas (ALTA FLORESTA, 2008; BERNASCONI; ADAB; MICOL, 2008).

Em linhas gerais, o uso do fogo foi responsável por altas taxas de contaminação do ar com partículas tóxicas. Artaxo e colaboradores (2005) mediram a poluição atmosférica da cidade de Alta Floresta durante 10 anos (1992 a 2002) (gráfico 7). Eles se concentraram nas partículas tóxicas que geram riscos à saúde. $\mathrm{Na}$ época da seca (agosto a outubro), foram encontradas concentrações semanais que variavam de 50 a 600 microgramas por metro cúbico de $\operatorname{ar}\left(\mu \mathrm{g} / \mathrm{m}^{3}\right)$. Nos dias de maior pico, os valores chegavam quase ao dobro tolerado pela Organização Mundial de Saúde (350 $\mathrm{mg} / \mathrm{m}^{3} /$ semana) (WHO, 2006a).

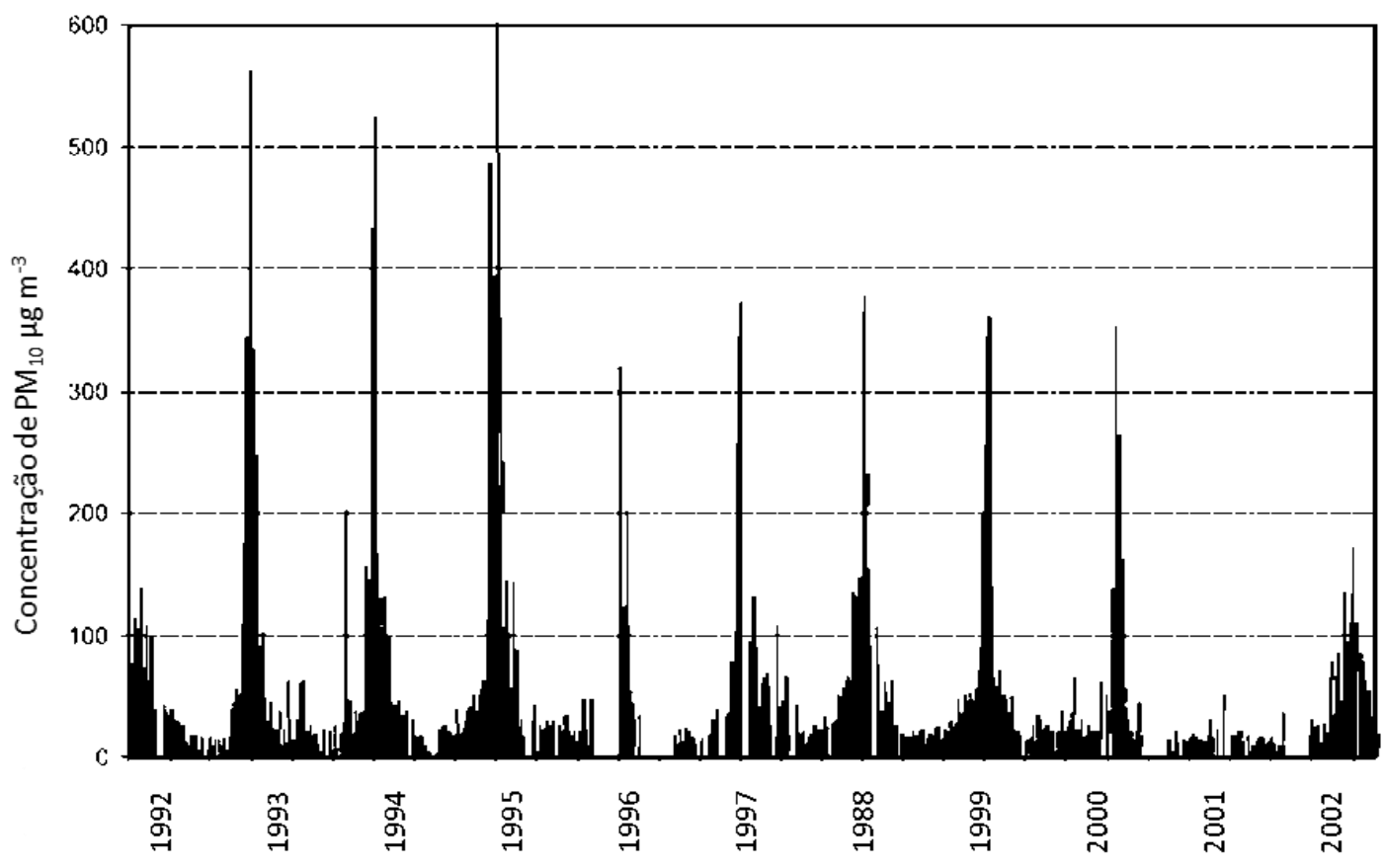

Gráfico 7 - Concentração de partículas tóxicas de fumaça em Alta Floresta, de agosto de 1992 a setembro de 2002. Fonte: Artaxo e colaboradores (2005).

\subsubsection{A reviravolta da degradação biofísica do meio ambiente}

Até o início dos anos 2000, o desmatamento era realizado de forma descontrolada. Segundo um dos profissionais da SMS/AF, as ações de fiscalização eram tão restritas que os agricultores consideram que a intensificação da fiscalização, ocorrida nos anos 2000, foi o resultado de uma nova Lei, quando, na verdade, ela executava as determinações do Código Florestal de 1965 e suas alterações subsequentes. 
O conjunto de medidas que "mudou as regras do jogo", como foi mencionado por um dos servidores da SMS/AF, integrou ações de fiscalização ambiental, detenção de servidores públicos e controle do licenciamento ambiental. O estopim deste processo foi a "Operação Curupira", deflagrada pela Polícia Federal, com apoio da Força Nacional de Segurança, em 2005. Tal operação resultou na detenção e exoneração de dezenas de servidores do IBAMA e do Escritório local da SEMA, envolvidos em corrupção. Ela também esteve relacionada ao fechamento da uma ampla maioria de indústrias madeireiras, que atuavam ilegalmente, e à apreensão de motosserras e caminhões usados no transporte de toras (MOURA, 2006).

Em termos econômicos, esta frente de fiscalização e combate ao crime ambiental trouxe importantes consequências. Depois do fechamento das madeireiras, o município vivenciou uma fase de desemprego e recessão que pôde ser comparada àquela que afetou a região no início dos anos 1990, quando ocorreu o fechamento dos garimpos.

No entanto, desta vez, a questão econômica se redefiniu rapidamente. Uma parcela importante de madeireiras regularizou as atividades, adequando-se em um programa de gestão de florestas nativas, que permite a extração da madeira, em função da aprovação de um Plano de Manejo Florestal Sustentável $\left(\mathrm{PMFS}^{99}\right)$. Esta mudança Ihes permitiu adentrar, de forma mais estável, no mercado internacional da madeira. Atualmente, o município exporta mensalmente cerca de oito mil toneladas de madeira de origem florestal (MDIC, 2014).

Ademais, em 2008, Alta Floresta foi inscrita na lista dos municípios prioritários para a prevenção e o controle do desmatamento, definida pelo MMA (Ministério do Meio Ambiente), por ter sido considerado um dos municípios que mais desmatavam na Amazônia. A repercussão da inserção do município na tal lista sensibilizou o mercado consumidor de carne, o que pesou, novamente, sobre a economia do município. Neste contexto, a sociedade civil, representada, sobretudo, pelos agropecuaristas, mobilizou-se para pressionar o poder público municipal a favor da retirada do município da referida lista do MMA. Em consequência, a Prefeitura Municipal, em parceria com as ONGs locais, criou metas que objetivavam melhorar a imagem ambiental do município. Entre as principais, constavam: (i) o chamamento dos produtores rurais - pequenos, médios e grandes -, para comprometerem-se com a redução da taxa anual de desmatamento e de queimadas e (ii) a elaboração conjunta de projetos, de amplo alcance, voltados à execução do Cadastro

\footnotetext{
${ }^{99}$ O Plano de Manejo Florestal Sustentável compõe um estudo prévio das condições da floresta, que ajuda a definir um conjunto de técnicas (plano de manejo) apropriado à produção madeireira. Ele é definido pelo CONAMA (Conselho Nacional do Meio Ambiente) e orienta a atividade de extração de madeira, assegurando um melhor aproveitamento dos recursos, com menor impacto da exploração.
} 
Ambiental Rural (CAR), incluindo a responsabilização pela recuperação de áreas degradadas (APPs - Áreas de Proteção Ambiental - e Reservas Legais).

De uma parte, o setor agropecuário assumiu uma agenda de compromissos ambientais, como a redução das taxas de desmatamento e dos focos de incêndio. De outra, aprovou-se dois grandes projetos, financiados pelo Fundo Amazônia ${ }^{100}$. Estes projetos executam um conjunto compartilhado de compromissos, assumido por produtores rurais, ONGs e a própria Prefeitura. Entre os resultados deste processo consta uma queda acentuada na taxa anual de desmatamento. A média de 20.000 hectares desmatados por ano, entre 2000 e 2005, caiu para cerca de 1.800 hectares/ano, a partir de 2007 (queda de 99\%) (INPE, 2014a; SOUZA, 2006). Constam, também, a recuperação de cerca de três mil hectares de áreas degradadas, por meio da implantação de SAFs (Sistemas Agroflorestais ${ }^{101}$ ) e a conquista do objetivo principal, a retirada do município da lista do MMA, o que ocorreu no ano de 2012.

As taxas de queimadas seguiram tendências similares. Neste caso, a redução foi de 97\%, de 2004 para 2013 (INPE, 2014b) (gráfico 8). Além da intensificação da fiscalização ambiental, por meio de operações policiais, este também é o resultado de uma série de outras medidas implantadas pelo governo federal na Amazônia, com o objetivo de reduzir a emissão de gases relacionados às mudanças climáticas (ABRAMOVAY, 2010). Entre elas, as ações de controle dos grandes incêndios florestais e a formação dos produtores para executar o manejo do fogo, executados pelo IBAMA (Instituto Brasileiro do Meio Ambiente e dos Recursos Naturais Renováveis), em parcerias com instituições nacionais e locais.

\footnotetext{
${ }^{100}$ Trata-se de um dispositivo proposto pelo governo brasileiro durante a COP-12, em Nairóbi (2006), que busca a contribuição voluntária de países em desenvolvimento para a Redução das Emissões por Desmatamento e Degradação florestal (REDD). Estes recursos, cuja gestão cabe ao BNDES (Banco Nacional de Desenvolvimento Econômico e Social), são destinados a projetos de prevenção, monitoramento e combate ao desmatamento e de promoção da conservação e uso sustentável no bioma amazônico. Em Alta Floresta são desenvolvidos dois grandes projetos "Olhos d'água da Amazônia" e "Sementes do Portal". De 2009 a 2014, eles acessaram um montante superior a 20 milhões de reais.

101 São formas de uso da terra em que são combinadas espécies arbóreas (frutíferas e/ou madeireiras) com cultivos agrícolas e/ou criação de animais.
} 


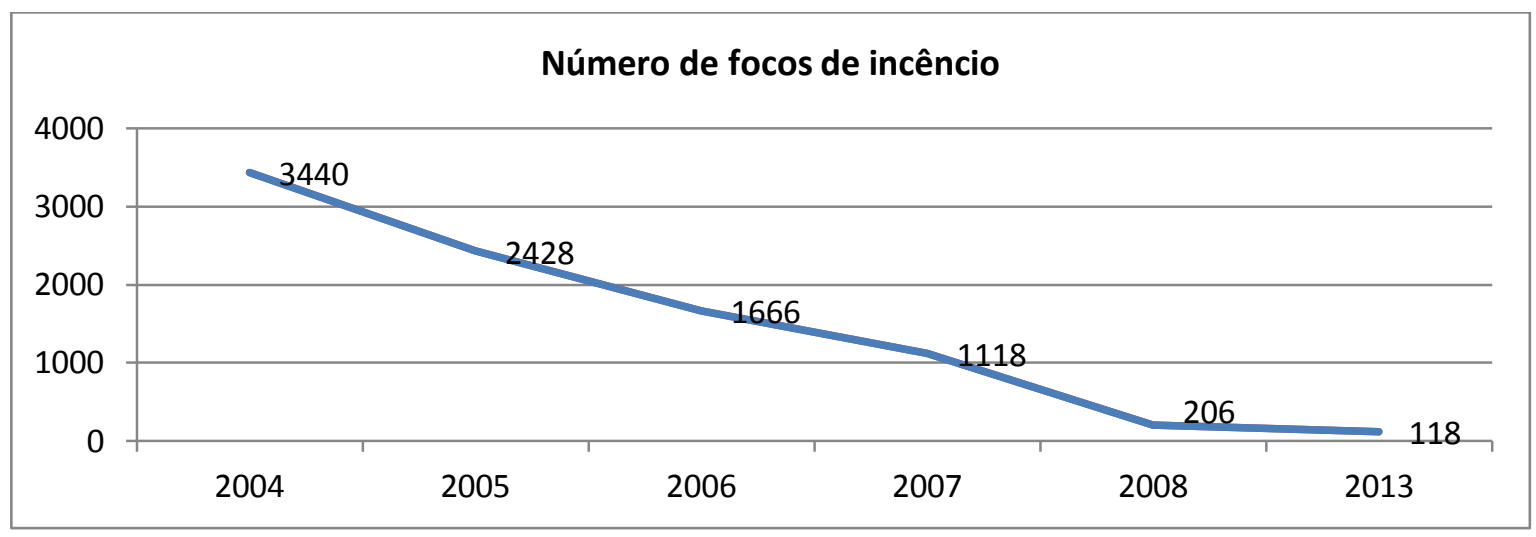

Gráfico 8 - Número de focos de incêndio - Alta Floresta, 2004 a 2013. Fonte: INPE, 2014b.

Localmente, estes dispositivos aumentaram a atenção, por parte dos órgãos públicos, ao uso do fogo. Os produtores receberam formações sobre o manejo do fogo, oferecidas pela Secretaria Municipal do Meio Ambiente em parceira com ONGs locais. Na perspectiva de um dos servidores da SMS/AF, a formação dos produtores se delineava da seguinte maneira: "- Você só vai queimar depois da segunda ou terceira chuva. - Ah? Mas como é que eu vou monitorar. - O negócio é o seguinte: Nós vamos trazer os pluviômetros e você vai monitorando. Se tiver o índice que nós estamos marcando, vocês queimam, senão não queimam. Aí vieram várias caixas de pluviômetro de acrílico que foram distribuídos nas comunidades". Adicionalmente, eles receberam orientações sobre o uso de aceiros, para evitar que o fogo se espalhe para outras propriedades. Esta dinâmica traz indicativos de uma efetiva contribuição para a redução das taxas de queimadas.

\subsubsection{A degradação biofísica e o momento atual}

Em termos ambientais, o que se observa, atualmente, é uma importante mudança no clima, sobretudo no que diz respeito ao prolongamento da estação seca. Segundo uma agricultora do bairro Vila Nova, "hoje chove bem menos que no início. Os poços de água derramavam no início. Agora, mesmo na época da chuva a água não sobe mais. Muitos poços que derramavam, agora secaram”. Além disso, há menções ao aumento do "mormaço", durante a estação seca. Cita-se que "o ar quente fica parado, antigamente não era assim".

Estudos desenvolvidos em Alta Floresta por Dubreuil (2002; 2005) e Dubreuil e colaboradores (2008) mostraram que o desmatamento tem influenciado, para cima, a temperatura ambiente, e, para baixo, a umidade relativa do ar. Estas diferenças são notadas, segundo os autores, principalmente na zona urbana e nas áreas de pastagem. No total, o aumento de temperatura observado atualmente no centro da cidade e nos sítios que 
a circundam, está entre 2 e $4^{\circ} \mathrm{C}$, o que é comparavelmente superior ao observado em regiões adjacentes, menos desmatadas. Os dados dos estudos comprovam que as formas de uso e ocupação agrícola, entre outros fatores, estão diretamente relacionadas a esta elevação da temperatura e redução da umidade relativa do ar (DUBREUIL, 2002).

O que se observa, em síntese, é que o acumulado de desmatamento, do início da ocupação à fase recente, pode ter deixado como herança uma importante alteração no ciclo das chuvas, na temperatura e na umidade do ar.

\subsection{Riscos à saúde associados ao desmatamento}

\subsubsection{A alta exposição a mosquitos}

Entre outros problemas encontrados pelos migrantes, na chegada à Amazônia, esteve a forte presença de mosquitos. Piuns ${ }^{102}$ (borrachudos), mosquitos-palha ${ }^{103}$ e pernilongos ${ }^{104}$, eram os de maior abundância. Para os agricultores, esses insetos eram, em grande parte, desconhecidos. Por conseguinte, pouco ou quase nada se sabia sobre a participação dos mosquitos na transmissão de doenças infectoparasitárias (malária, leishmaniose, febre amarela, etc.).

Os piuns incomodavam devido à sua alta densidade e a irritação provocada pelas inúmeras picadas. Segundo um servidor da SMS/AF, à época, muitas pessoas circulavam com roupas que cobriam todo o corpo, deixando aparentes apenas os olhos. Esta estratégia era utilizada principalmente pelas mulheres e crianças. Este grupo focal também mencionou a importância da presença dos insetos nas decisões de permanência ou migração das famílias, de volta para as suas regiões de origem ou em direção a novas fronteiras.

A presença dos mosquitos-palha não causou os mesmos incômodos que os piuns. Eles eram menos abundantes. O problema, contudo, foi a disseminação da leishmaniose

\footnotetext{
102 Insetos da família das moscas, do gênero Simulium, são antropófagos (alimentam-se de sangue humano), silvestres e têm hábito diurno. Eles são capazes de transmitir a oncocercose ${ }^{102}$, uma doença parasitária que pode levar o paciente à cegueira (NEVES, 2006). No entanto, não há registros de quaisquer manifestações deste tipo na região de Alta Floresta, provavelmente porque o agente da doença não tenha sido introduzido na região.

${ }^{103}$ Mosquitos do gênero Lutzomyia, também são antropófagos silvestres e transmitem os agentes da leishmaniose tegumentar americana, conhecida como úlcera-de-Bauru, e da leishmaniose visceral. Somente a primeira doença existe na região de Alta Floresta. Também são conhecidos por birigui e tatuquira, entre outros.

${ }^{104}$ Principalmente dos gêneros: (i) Anopheles, inseto autóctone da Amazônia, predominantemente silvestre, transmissor da malária, e (ii) Culex, pernilongo doméstico, transmissor da filariose bancroftiana (uma forma de elefantíase).
} 
tegumentar americana, uma doença provocada por um microrganismo protozoário ${ }^{105}$ e conhecida como úlcera-de-Bauru. Há registros de sua ocorrência desde a chegada dos primeiros migrantes até os dias atuais. Os mosquitos transmissores são silvestres, autóctones da Amazônia e tem hábitos diurnos (NEVES, 2006). Na primeira fase da ocupação, os tratoristas, serradores, agricultores e garimpeiros, eram os que estavam mais expostos ao risco da doença.

Os pernilongos domésticos logo se tornaram comuns nas habitações rurais e urbanas. Mas, este fenômeno não se traduziu em problemas de saúde pública. De fato, eram os mosquitos silvestres, transmissores da malária, que ofereceram os maiores riscos. Estes riscos estavam associados, em primeiro lugar, às próprias condições de moradia. Segundo Paulo, um dos entrevistados, "as pessoas, quando chegavam, faziam um barraco de lona, e ali se instalavam. Abriam, primeiro, a mata, plantavam o café, o cacau ou o arroz, depois construíam as casas, que eram feitas de tabuas cortadas com motosserras e cobertas com lascas de madeira feitas com o machado. A maioria não tinha banheiro. Os que levavam a higiene mais a sério construíam latrinas. A maioria não tinha nada".

Não havia, na percepção dos participantes dos quatro grupos focais, a "cultura" da malária e, portanto, faltavam conhecimentos para tomar certos cuidados referentes ao contato com os insetos transmissores. "As pessoas estavam expostas aos mosquitos na hora do banho, de ouvir o rádio", comentou-se no grupo focal do ERS/AF. A exposição também era intensa durante as atividades de trabalho, principalmente no desmatamento e nas áreas agrícolas.

Em linhas gerais, observa-se que a exposição aos mosquitos esteve associada às condições de moradia e de trabalho. No entanto, há um fator que é anterior a estas características. Trata-se da relação estabelecida entre os trabalhadores e a mata. A floresta amazônica abriga a mais importante espécie brasileira envolvida na transmissão da malária, o Anopheles darlingi. Este inseto prefere o entorno da floresta, onde encontra as condições favoráveis à sua reprodução, devido à maior incidência solar e a maior concentração de poças d'água, criadas pela redução da permeabilidade do solo (NEVES, 2006). À medida que os agricultores avançavam com o desmatamento, eles aumentavam a incidência da luminosidade e umidade exatamente no mesmo local em que trabalhavam. Isso significa dizer que o lócus de trabalho tornava-se também o lócus de reprodução do mosquito transmissor da malária, aumentando o risco da infecção.

Outro fator que provocou o aumento dos mosquitos foi a própria presença humana no ambiente silvestre. A abundância de sangue humano, o principal alimento diante da redução

${ }^{105}$ Existem várias espécies de protozoários que respondem pela causa da doença. Elas pertencem ao gênero Leishmania. 
da fauna silvestre gerada pelo desmatamento e a caça favoreceu a multiplicação dos insetos (CASTRO et al., 2006).

A exposição ao mosquito era mais intensa nos garimpos de ouro. Segundo uma agricultora do Bairro Vila Nova, os garimpeiros "jogavam uma "boroca"106 nas costas, com uma rede e um bocado de roupa e sumiam. Chegavam lá, dormiam em rede, expostos a tudo". Trabalhavam geralmente sem camisa e dentro da água (figura 34a). Quando adoeciam "nem sempre recebiam socorro. Em alguns casos, não havia estradas que ligavam os garimpos à cidade. As saídas eram só de avião". Assim, "diferente dos que vieram colonizar e que, quando se sentiam mal, corriam para buscar o tratamento e seguiam o tratamento, a vida do garimpeiro era desregrada. Ele se afundava lá no mato e ele só vinha quando dava para vir, quando ele tirava o ouro e se sentia satisfeito". No que se refere aos cuidados preventivos, conta-se que só quando a malária "estourou, ele começou a prevenir a doença, dormia em "fuscão" ${ }^{107}$, levava mosquiteiro, repelente e remédio" (figura 34b).

De forma mais ampla, o aumento do risco para a malária, decorrente da maior exposição ao mosquito, pode ser explicada pela relação que se estabeleceu com a natureza. Esta relação foi guiada, majoritariamente, por uma visão antropocêntrica, própria dos migrantes e, sobretudo, daqueles que planificaram a transformação da Amazônia em fronteira agrícola (governantes, empresários, etc.). Não é novidade que a Amazônia foi percebida como objeto de domínio, durante a fase de ocupação agrícola (GUIMARÃES NETO, 2003). Os agricultores do Bairro Vila Nova contaram que vieram para a Amazônia "preparados para desbravar a floresta". Ela precisava ser domada para ser transformada em área produtiva. Aqueles que não tinham esta coragem, não serviam para participar da formação da fronteira (LE BORGNE-DAVID, 1998). Neste contexto, nenhum tipo de consequência da transformação da floresta, em termos ecossistêmicos ou em relação à vida humana, foi levado em conta (CONFALONIERI, 2005).

\subsubsection{Malária}

\subsubsection{A emergência da doença}

A figura 22 nos ajuda a descrever e melhor compreender os fatores que contribuíram para a emergência da malária e para o controle da epidemia. Trata-se de uma síntese, elaborada a partir dos resultados das discussões realizadas com os participantes dos grupos focais. O texto que segue faz alusão aos pontos destacados no esquema.

\footnotetext{
106 Mochila.

107 Uma cobertura de lona preta.
} 


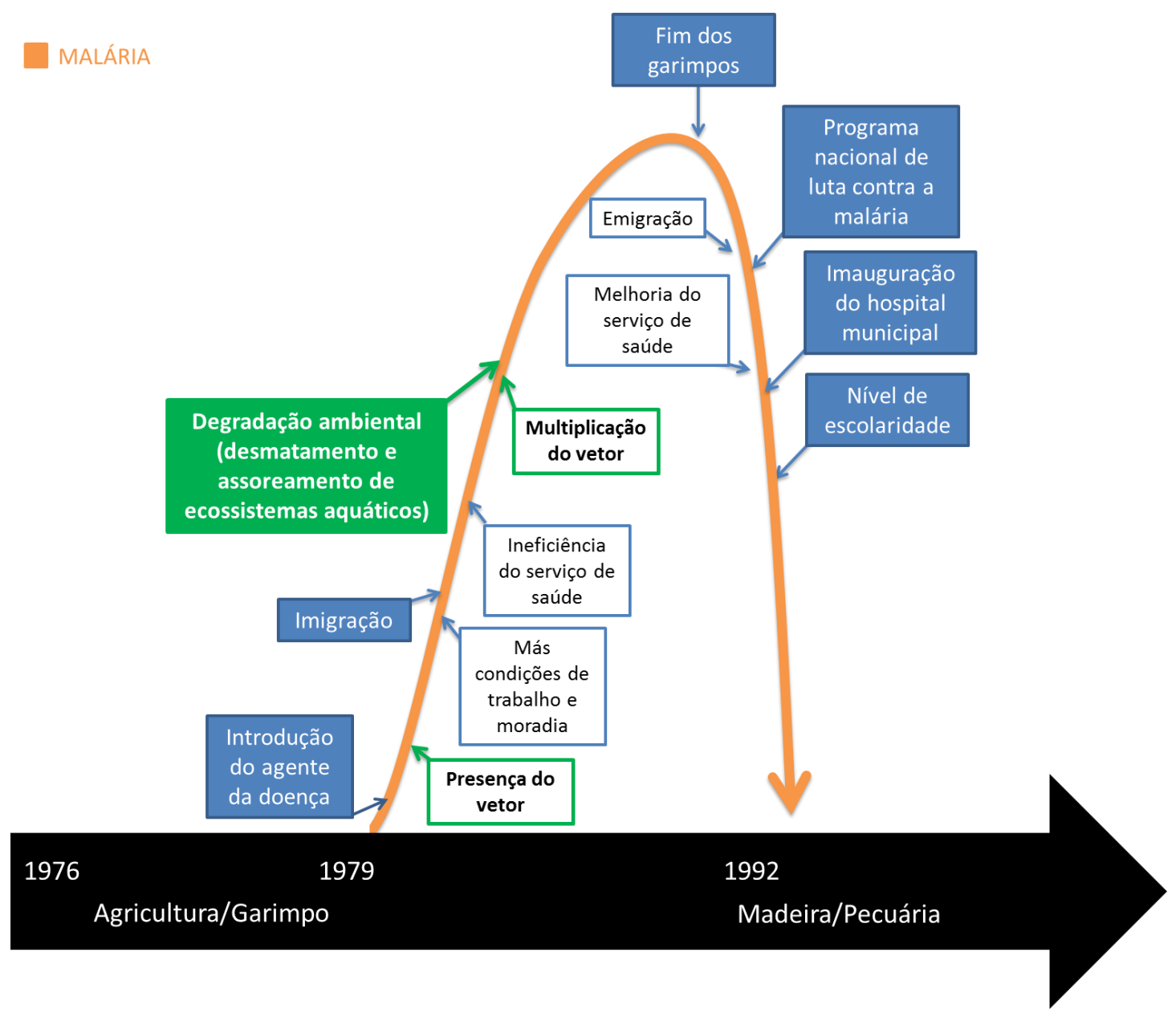

Figura 22 - Fatores que contribuíram para a emergência da malária e para o controle da epidemia na fronteira agrícola de Alta Floresta. Autoria própria. Fonte: Pesquisa de campo, março de 2013 e agosto de 2014.

A região de Alta Floresta só conheceu a malária no ano de 1979. Até então, mesmo expostos aos mosquitos, os trabalhadores não desenvolviam a doença porque o agente causador da malária (Plasmodium) ainda não havia sido introduzido na região. Esse agente chegou, segundo relatos, em companhia dos garimpeiros infectados. Ele se instalou na região devido à presença do mosquito transmissor e se disseminou, entre outros fatores, em razão da multiplicação deste mosquito, provocada, como explicado anteriormente, pela conversão da floresta em área de cultivo e a presença humana.

Diante do quadro de elevação do número de mosquitos infectados e a alta mobilidade populacional, o serviço de saúde não conseguiu impedir o avanço da epidemia. O maior número de casos foi registrado entre os anos 1987 a 1992. Segundo um dos profissionais da FUNASA, neste período, eram feitas, diariamente, entre 100 e 300 lâminas ${ }^{108}$ sanguíneas $^{2}$

${ }^{108}$ A preparação de lâminas é o método mais usado para o diagnóstico da malária. É coletada uma pequena quantidade de sangue que é esfregada (esfregaço) sobre uma lâmina de vidro. Esta lâmina é observada ao microscópio. Se o material estiver contaminado, são encontradas formas sanguíneas 
de pessoas suspeitas de apresentar a doença. O grau de positividade variava entre 30 e 40\%. "1992 foi o pico, a SUCAM fechou o ano com 36 mil diagnósticos, $55 \%$ de positividade", comentou. Para se ter uma ideia mais precisa da dimensão do problema, à época, em Paranaíta, município de 11 mil habitantes, foram diagnosticados 12 mil casos de malária em um ano ${ }^{109}$.

Para um servidor da SMS/AF, "todos pegavam a doença. O piloto do garimpo pegava a doença tanto quanto ao garimpeiro. A diferença esteve na origem das pessoas. Algumas estavam mais preparadas para buscar assistência médica". Os mais resistentes à busca por tratamento eram os garimpeiros. Entre os fatores que os mantinham em campo, mesmo doentes, estavam as dificuldades logísticas (ausência de estradas) e, principalmente, econômicas. Há relatos que "alguns morriam no intervalo de tempo entre a coleta de sangue e o resultado do diagnóstico" (4 horas ou mais), sentados nas cadeiras da sala de espera da SUCAM

Entre as populações paranaenses, a malária era totalmente desconhecida. Em primeiro lugar, porque o Estado do Paraná não é uma região de ocorrência natural da doença, devido à baixa densidade de mosquitos transmissores. Em segundo, porque não houve qualquer tipo de conscientização das populações migrantes, por parte do governo ou da empresa colonizadora, sobre o risco de contrair a doença. Por conseguinte, as pessoas só descobriram a malária, depois de ela se disseminar pela região. Mesmo assim, em alguns casos, eles não identificavam a doença. "Achavam que era gripe e acabavam morrendo", citou uma das agricultoras do Bairro Vila Nova.

Segundo Rogério, um dos entrevistados, as famílias de agricultores foram afetadas, principalmente, devido ao envolvimento dos homens na atividade garimpeira. "Eles saíam do sítio para conseguir um recurso extra no garimpo e, na volta, infectavam toda a família". Os gastos com a doença consumiam um volume considerável dos recursos financeiros desses agricultores. Em situações extremas, "alguns perderam tudo por causa da malária", afirmou um agricultor do Bairro Vila Nova.

A partir de retrospectiva histórica é possível afirmar que esta foi, de fato, a doença que trouxe os maiores prejuízos à saúde da população local. Ademais, comenta-se que o próprio projeto agrícola não se efetivou como o planejado, devido à interferência da epidemia. $\mathrm{A}$

do protozoário do gênero Plasmodium. Como estas formas se distinguem conforme a espécie, o técnico, responsável pelo exame laboratorial, pode identificar que tipo de malária possui o paciente: "falciparum", "malarie" ou "vivax". Das três, a malária "falciparum" é a mais agressiva e, portanto, exige maior atenção médica.

109 Este fenômeno pode ser explicado pelo fato de, em alguns casos, uma mesma pessoa pode ter desenvolvido a doença mais de uma vez ao ano. Também é válido considerar que em localidades de garimpo, como em Paranaíta, àquela época, uma parte da população é transitória, o que aumenta a margem de erro na contagem populacional. 
época da epidemia é concebida pela população local como a fase mais difícil da história desta fronteira, que só pôde ser controlada graças ao enfrentamento da doença, estimulado pelo sistema de saúde.

\subsubsection{O controle da epidemia}

$\mathrm{Na}$ compreensão um dos entrevistados, o nível de escolaridade das famílias de agricultores foi um fator importante para a implantação de mecanismos de preservação da malária. "Uma boa parte das pessoas que veio para a agricultura já tinha uma formação escolar. O Estado do Paraná era muito exigente em relação à educação", relatou Paulo. Por conseguinte, entende-se que as condições de disseminação da doença não foram piores porque as famílias não tiveram dificuldade em adaptar os seus hábitos diante da perspectiva de infectarem-se com o mosquito. Elas compravam mosquiteiros, ajudavam no trabalho da SUCAM, sobretudo de pulverização, e completavam o tratamento.

Entre os garimpeiros a questão era mais sensível. Eles frequentemente abandonavam os tratamentos e contribuíam, assim, com a ressurgência da infecção, colaborando também, desta forma, para a manutenção do foco da doença na região. Além disso, eles reproduziam alguns mitos em relação à malária, como a crença de que ela se disseminava a partir da lama. Segundo um agricultor do Bairro Vila Nova, muitos acreditavam que era possível identificar um local favorável à infecção a partir do cheiro da terra encharcada. Assim, por vezes, instalavam-se em locais próximos aos criadouros dos mosquitos, acreditando ser este o ambiente adequado para prevenir-se da doença, porque "não tinha cheiro de malária".

Mas não só de conhecimentos "mágicos" se alimentava essa população. Alguns saberes foram importantes para reduzir o sofrimento provocado pela malária. Segundo narrativas, "as pessoas se tratavam com o melão-de-são-caetano ${ }^{110}$ e quina"111. Este conhecimento foi transmitido por migrantes da região Norte do país. Eram feitas infusões das folhas do melão-de-são-caetano e chás da casca das árvores de quina. Havia também quem se prevenisse fazendo uso de alho ou uma mistura de fedegoso (Cassia sp.) com óleo de rícino (óleo de mamona). Segundo depoimentos de agricultores do Bairro Vila Nova, esses tratamentos ajudaram alguns a se curar. Outros morreram ou conheceram repetidas fases de ressurgência dos sintomas da doença.

No ano de 1992, o garimpo entrou em crise e gerou, como consequência, um esvaziamento populacional. Muitos trabalhadores voltaram para a sua região de origem ou

\footnotetext{
${ }^{110}$ Da espécie Momordica charantia.

111 As cascas da quina (Cinchona sp.) são ricas em quinino, uma substância presente em medicamentos usados no tratamento da malária.
} 
seguiram em direção a outros garimpos. Segundo estudos, tal redução da densidade populacional pode ter ajudado a reduzir a frequência dos casos de malária (BARBIERI, 2007; CASTRO et al., 2006). Além disso, o fechamento dos garimpos também contribuiu com a diminuição do trânsito garimpo-cidade, reduzindo a capacidade de circulação do agente de doenças e, por conseguinte, de infecção de novos hospedeiros.

Deste modo, ao diminuir o número de pessoas doentes, reduziu-se também a presença do Plasmodium na população de mosquitos, o que provocou a brusca redução do número de casos. "A partir de 1993, o número de lâminas feitas pela SUCAM [que ultrapassavam os $30 \mathrm{mil}$ caiu para 3 a 4 mil/ano", argumentou um profissional da FUNASA.

Outro fator decisivo para contenção da epidemia foram os mutirões de diagnóstico e tratamento de viajantes, realizados pela SMS/AF, entre os anos de 1992 e 1993. Nas estradas que davam acesso à cidade foram colocados correntões que serviam para barrar a passagem dos trabalhadores que circulavam entre os garimpos e a cidade, bem como, dos caminhoneiros que trabalhavam para as madeireiras ou fazendas de gado. Estas pessoas eram "obrigadas a fazer o diagnóstico sanguíneo ali mesmo, à beira da estrada", comentou uma enfermeira da SMS/AF. Caso o resultado fosse positivo, elas somente eram liberadas depois de fazerem uso assistido do medicamento antimalárico.

Estudos epidemiológicos, baseados nos registros oficiais ${ }^{112}$ dos casos de malária, mostram que o número de casos, no município, caiu de 209,1 por mil habitantes, no início dos anos 1990, para 9,6 casos em 1.000 habitantes, no final da mesma década (ATANAKASANTOS et al., 2006). Para Castro e colaboradores (2006), o nascimento de uma coesão comunitária, teve um importante papel nesse processo. Segundo os profissionais da SMS/AF, na fase mais crítica da epidemia, o sistema de saúde se aliou à população local para prevenir e controlar a doença. Quando os últimos doentes foram tratados, o Plasmodium foi eliminado da região. Assim, a presença dos mosquitos (livre do agente causador) não foi mais suficiente para disseminar a doença.

Em 2010, entretanto, a malária voltou a preocupar os sistemas municipais de saúde de Alta Floresta e Paranaíta. A inquietação foi gerada pelas perspectivas criadas pela instalação das usinas hidrelétricas (UHEs) no rio Teles Pires (UHE Colíder e UHE Teles Pires). A chegada de mais de 10 mil trabalhadores, muitos deles, provindos de usinas como as de Santo Antônio e Jirau, em Rondônia, onde as obras estiveram relacionadas a uma epidemia recente de malária, preocupava o serviço de saúde. Contudo, em 2014, quatro anos depois do início das obras, o número de casos de malária na região ainda se mantinha dentro do limite tolerável que é estabelecido pela OMS. Um sistema de controle individual,

${ }^{112}$ Nesta época, uma parcela significativa dos casos de doenças não era registrada no sistema de informação do sistema de saúde devido, sobretudo, a falhas no sistema. 
instalado na entrada dos canteiros de obras e o monitoramento constante dos doentes, contribuíram para eliminar o risco de uma nova epidemia da doença na região. No quadro atual, são registrados cerca de 100 casos da doença por ano (MATO GROSSO, 2014).

Além disso, considera-se que a população local tenha adquirido certa imunidade, depois das repetidas crises da doença (DE CASTRO; SAWYER; SINGER, 2007). No conjunto populacional, este fator dificultaria a instalação de uma nova epidemia na região.

Por fim, existem obstáculos criados pelo próprio sistema de saúde que dificultam a reemergência da doença. Este aspecto se deve ao acúmulo de aprendizagens que, segundo uma enfermeira da SMS/PT, "aumenta a capacidade de acerto diante de uma nova situação de risco". Tem-se, hoje, maior capacidade de vigilância e de atendimento aos doentes.

\section{Conclusão}

Este capítulo destaca os problemas ambientais gerados pelas formas de uso e ocupação do espaço, praticadas durante o avanço da fronteira em Alta Floresta. Em linhas gerais, observa-se que o desmatamento esteve vinculado ao próprio projeto de ocupação agrícola. Na fase atual, estes fenômenos foram freados pela intensificação da fiscalização ambiental e a imposição de restrições de comercialização de alimentos produzidos em áreas de desmatamento ilegal.

Nas primeiras duas décadas de ocupação agrícola, a dinâmica envolvida no desmatamento esteve relacionada à explosão da epidemia de malária. De uma parte, esta participação da devastação ambiental na emergência e prevalência da doença é explicada pelas transformações sofridas pelo ecossistema florestal. O aumento da incidência solar nos remanescentes florestais, sobretudo nas bordas da floresta, melhorou as condições de reprodução do inseto vetor da doença. O mesmo ocorreu em decorrência do aumento das áreas agrícolas, as quais diminuíram a permeabilidade do solo e aumentaram a concentração de poças d'água. Além disso, a maior parte dos trabalhadores envolvidos com o desmatamento, seja na agricultura ou nos garimpos, trabalhava neste espaço de borda das florestas de maior densidade de mosquitos. Por conseguinte, a alta exposição humana a uma população de insetos cada vez maior foi determinante para o aumento do número de casos da doença na região. 


\section{Capítulo 9. CONTAMINAÇÃO TÓXICA DO MEIO AMBIENTE E RISCOS À SAÚDE NO CONTEXTO DA FRONTEIRA AGRÍCOLA DE ALTA FLORESTA: DOENÇAS CRÔNICAS}

\section{Introdução}

Vimos no capítulo anterior que a degradação biofísica do meio ambiente teve significativa importância para a disseminação e prevalência de doenças infectoparasitárias. Para compreender este fenômeno, abordamos a dinâmica de emergência e controle da epidemia de malária. Neste capítulo, atemo-nos à relação entre a contaminação tóxica do meio ambiente, produzida principalmente pela ocupação agrícola e garimpeira, e a recente emergência das doenças crônicas. As formas de controle dessas doenças ainda são pouco efetivas. Algumas pistas, que podem contribuir para que a região avance em direção à minimização da prevalência destas doenças, são apresentadas nas considerações finais.

$\mathrm{Na}$ primeira parte deste capítulo, abordamos os efeitos do uso do fogo à saúde respiratória. Na segunda, tratamos da relação entre o uso e a exposição humana aos agrotóxicos e ao mercúrio e a emergência das demais doenças crônicas. O cerne da discussão é alimentado pelos resultados da pesquisa de campo. Adicionalmente, são recuperados alguns conhecimentos publicados em uma série de outros estudos desenvolvidos principalmente na área da epidemiologia.

\subsection{O uso do fogo e o risco para as doenças respiratórias}

A fase crítica das queimadas, segundo os participantes da pesquisa, durou do início dos anos 1990 a meados da década de 2000. Os incêndios perduravam por vários dias ou, em alguns casos, até semanas. Para uma agricultora do Bairro Vila Nova, "na época de agosto, o sol desapareceria durante todo o mês. Ardia o nariz. O ônibus não podia circular, tinha que esperar diminuir a fumaça, para conseguir passar". Este mês era o mais significativo em termos de contaminação atmosférica por caracterizar a fase mais intensa da estação seca e, portanto, de maior inflamabilidade da floresta (ARTAXO et al., 2005).

No período de maior propagação das queimadas, a internação hospitalar aumentava substancialmente. Segundo o relato de uma ex-garimpeira do Bairro Vila Nova, no ano de 1993, "quando as proximidades da cidade foram desmatadas e queimadas, as pessoas ajudaram a levar crianças para o hospital. Todos os hospitais ficaram lotados". Ademais, fala-se, com frequência, das enormes filas que se formavam nos postos de saúde, para as 
crianças receberem inalação (nebulização), um das formas de administração de medicamentos contra doenças respiratórias agudas (problemas das vias inferiores, bronquites, etc.).

A dimensão do problema é revelada pelo número de atendimentos médicos por doenças respiratórios realizado no município. Um estudo desenvolvido por Pereira e colaboradores (2011), durante o período de julho de 2005 e junho de 2006, mostrou que, no ano da pesquisa, foram registrados 11.818 casos de doenças respiratórias. Isso significa que mais de $20 \%$ da população do município adoeceu. A principal causa deste quadro foi a exposição direta ou indireta à fumaça emitida pelas queimadas. Em mais de $10 \%$ do total de atendimentos médicos, as partículas tóxicas emitidas pelas queimadas estiveram diretamente relacionadas com o adoecimento.

Desde 2005, uma equipe da FIOCRUZ (Fundação Oswaldo Cruz), do Rio de Janeiro, coordenada por Carmo (2010), De Oliveira (2011) e Ignotti (2007, 2010a), entre outros, vem trabalhando no monitoramento dos níveis de partículas atmosféricas tóxicas, emitidas pelas queimadas, e no levantamento da frequência das internações hospitalares por doenças respiratórias. Os estudos indicam que, embora o nível de exposição aos poluentes do ar tenha sido razoavelmente o mesmo para todos os grupos, de forma geral, as crianças e os idosos foram os grupos mais afetados. Isso ocorreu devido à vulnerabilidade biológica destes grupos e porque a sua saúde respiratória pode ser comprometida, inclusive, em condições de baixa concentração de partículas tóxicas no ar (IGNOTTI et al., 2010a).

Os estudos desenvolvidos no município por Jacobson e colaboradores (2012) e Carmo e colaboradores (2010), dão uma melhor dimensão do risco à saúde, gerado pelo uso do fogo nesta fronteira agrícola. Segundo os autores, o aumento mínimo de $10 \mu \mathrm{g} / \mathrm{m}^{3}$ no nível das partículas no ar $\left(\mathrm{PM}_{2.5}\right)$, é suficiente para aumentar as consultas de ambulatório de crianças, devido a doenças respiratórias (CARMO et al., 2010). No ano de 2006, em Alta Floresta, a média diária de concentração de partículas tóxicas no ar variou de 6,39 a 99,91 $\mu \mathrm{g} / \mathrm{m}^{3}$ (JACOBSON et al., 2012). Isso significa que a concentração de substâncias tóxicas na atmosfera ${ }^{113}$, devido às queimadas, verificada no município, oferecia, aos grupos mais vulneráveis, um risco até $100 \%$ maior para o desenvolvimento de doenças respiratórias, do que em condições ambientais naturais (sem a presença de contaminantes atmosféricos oriundos da queima da biomassa). Nos meses mais críticos eram os de menor umidade relativa do ar, entre agosto e setembro (JACOBSON et al., 2012).

\footnotetext{
${ }^{113}$ Vale lembrar que o limite máximo semanal estabelecido pela Organização Mundial de Saúde é 350 $\mu \mathrm{g} / \mathrm{m} 3$ (WHO, 2006a).
} 
Estes estudos mostram que os riscos para as doenças respiratórias agudas, ao longo do avanço da fronteira agrícola em Alta Floresta, tiveram uma relação direta com as queimadas. É notório, neste sentido, que o período de maior intensidade dos incêndios equivalia à fase de maior prevalência destas doenças. Nesta perspectiva, pode-se afirmar que a emergência das formas agudas das doenças respiratórias, nesta fronteira agrícola, teve relação direta com a degradação ambiental.

\subsection{Doenças respiratórias: um mal de fronteira}

Além da fumaça, os profissionais da SMS/PT citaram a participação de fungos, agentes da blastomicose, e da exposição à poluição atmosférica de caráter mais recente, gerada principalmente por automóveis e caminhões.

A figura 23 oferece elementos que nos ajudam a melhor compreender este fenômeno e explicá-los, no texto que segue.
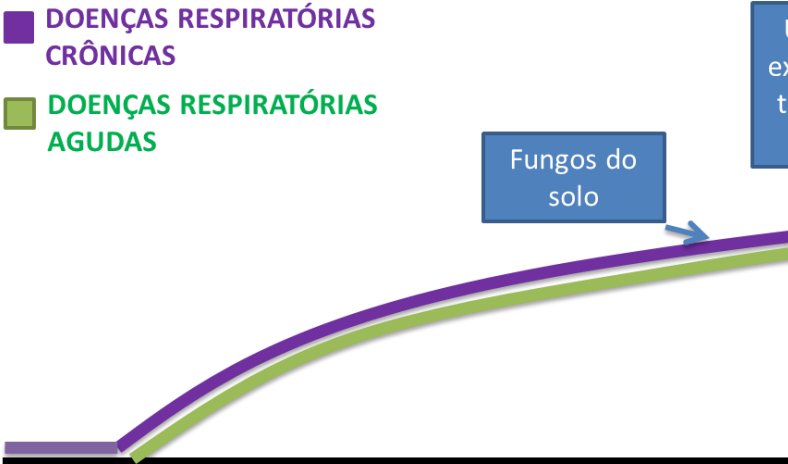

1992
2005
Uso de tabaco e

exposição a outros

tipos de poluição atmosférica

Controle das queimadas

Degradação

ambiental

(queimadas)

Madeira/Pecuária

Pecuária/Soja/Hidrelétricas

Figura 23 - Fatores que contribuíram para a emergência das doenças respiratórias agudas e crônicas e para o seu controle na fronteira agrícola de Alta Floresta. Autoria própria. Fonte: Pesquisa de campo, março de 2013 e agosto de 2014.

Em 2007, uma pesquisa sobre a prevalência da asma no município encontrou os sintomas da doença em mais $20 \%$ dos estudantes. O estudo concluiu que "Alta Floresta está entre os municípios brasileiros com uma das maiores prevalências de asma da América Latina entre escolares na faixa etária de 6 e 7 anos de idade" (FARIAS et al., 2010, p. 49). As causas desse problema, segundo os pesquisadores, era a intensidade da poluição atmosférica, verificada durante o período da seca.

Também em 2007, o município foi escolhido como prioritário para uma avaliação do efeito das queimadas à saúde. O estudo base para esta escolha mostrou que, de 2000 a 
2004, de cada 100 internações de crianças menores de 5 anos, nos hospitais de Alta Floresta, 80 deviam-se a problemas respiratórios. Isto significa que, de longe, o principal problema de saúde na infância era gerado pelas queimadas. A posição ocupada pelo município no ranking estadual da mortalidade infantil por doenças do aparelho respiratório revela, com mais clareza, da dimensão do problema. Ainda recentemente, Alta Floresta ocupava o segundo lugar, entre os 141 municípios do Estado (IGNOTTI et al., 2007).

A relação entre essas taxas de morbidade e mortalidade e as queimadas foi comprovada por outro estudo coordenado por Ignotti (2010). Neste caso, foi medida a concentração de partículas $\mathrm{PM}_{2.5}$ na atmosfera durante a estação seca e os resultados foram correlacionados com o percentual de internações hospitalares de pessoas idosas. Concluiu-se, com a pesquisa, que o aumento de $10 \mu \mathrm{g} / \mathrm{m}^{3}$ de partículas $\mathrm{PM}_{2.5}$ na atmosfera promovia um acréscimo de $6,8 \%$ nas internações hospitalares. Como no ano de 2010 , as emissões diárias variavam de 44.5 a $257.5 \mu \mathrm{g} / \mathrm{m}^{3}$, a taxa diária de internações de idosos, nos dias de pico das queimadas, pode ter sido $100 \%$ maior que em dias normais, de pouca incidência de queimadas.

Vale ressaltar que em 2010, quando Ignotti e sua equipe desenvolveram o referido estudo, grande parte das queimadas já estava sob controle. Este controle resultou, como ocorreu com o desmatamento, do conjunto de ações governamentais que intensificou a fiscalização ambiental e o manejo do uso do fogo nas pastagens, a partir de 2005. Tais ações contribuíram, consequentemente, com a queda da frequência das doenças respiratórias agudas.

Esta nova dinâmica não reduziu, contudo, a prevalência das doenças respiratórias crônicas. O que se observa, atualmente, é que a prevalência das formas crônicas das doenças respiratórias, nesta região, se coloca em um nível semelhante ao quadro nacional. Este fenômeno sugere, entre outros fatores, que as causas da atual forma crônica estejam relacionadas a fenômenos e comportamentos de tendência generalizada globalmente, como a poluição atmosférica emitida por automóveis e o consumo de tabaco.

\subsection{Contaminação tóxica do meio ambiente e o aumento do risco para doenças crônicas}

As doenças crônicas formam um conjunto de doenças não-transmissíveis que compreende, inclusive, as doenças respiratórias, já abordadas. Segundo os participantes grupos focais, os agravos de maior prevalência, nesta fronteira, são os respiratórios, os cardiovasculares (circulatórias e cardíacas) e os neurodegenerativos (mal de Parkinson e doença de Alzheimer, entre outras), bem como as diversas formas de câncer. A 
manifestação deste grupo de doenças advém desde a primeira fase de ocupação. No entanto, na fase atual elas se tornam o principal problema de saúde pública da região. A figura 24 nos ajuda de compreender este fenômeno, ao tempo em que oferece elementos para a discussão que segue. 


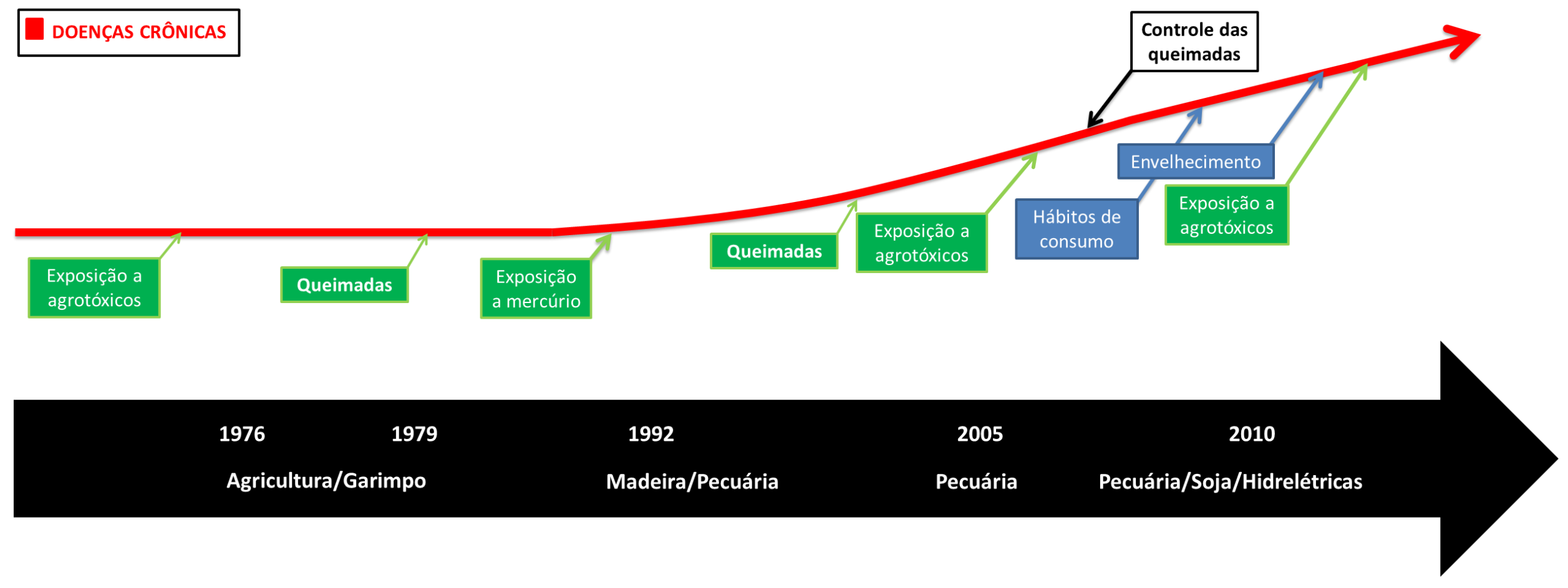

Figura 24 - Linha histórica do comportamento das doenças crônicas (respiratórias, cardiovasculares, neurodegenerativas e cânceres) na fronteira de Alta Floresta. Autoria própria. Fonte: Pesquisa de campo, março de 2013 e agosto de 2014. 


\subsubsection{Formas de contaminação tóxica do meio ambiente e riscos associados}

\subsubsection{Agrotóxicos}

Quando migraram para Alta Floresta, muitos agricultores traziam em seu histórico uma elevada e prolongada exposição a agrotóxicos. No Estado do Paraná, eles usavam inseticidas organoclorados de alta toxicidade, como o DDT, o Aldrin e o $B \mathrm{CC}^{114}$ (inseticidas organoclorados). Esta prática era amplamente disseminada no combate à broca-do-café, na década de 1970, e continuou se reproduzindo por mais de duas décadas, na região de Alta Floresta. A aplicação dos produtos era realizada sem o uso de qualquer tipo de equipamento de proteção individual (luvas e botas de borracha, óculos ou respiradores).

O uso destes produtos foi disseminado na agricultura brasileira a partir dos anos 1960, por meio de um conjunto de políticas governamentais que visavam o aumento da produção agrícola, via modernização da agricultura. Além de ser socialmente excludente ${ }^{115}$, a política aumentou significativamente o poder da indústria de sementes, insumos e pesticidas. Nestas circunstâncias, o DDT e o BHC se tornaram conhecidos como a "salvação" da agricultura. Os produtos agradavam aos agricultores em razão do baixo custo e a alta eficiência em termos de controle de pragas, fatores que contribuíam para o aumento da produtividade e da renda.

Entre os produtores, os inseticidas eram conhecidos como "remédio", uma versão propagandeada pela indústria, com o objetivo de diminuir o receio de sua utilização. Segundo um agricultor do Bairro Vila Nova, os agricultores e os trabalhadores que atuavam na pulverização, em Alta Floresta, pouco ou nada conheciam sobre os danos que os compostos poderiam causar à saúde. Eles comentaram, inclusive, que os trabalhadores mediam a eficácia da dedetização ${ }^{116}$, em relação à eliminação das pragas, de acordo com o grau do mal-estar que sentiam, após o término da aplicação da solução. Assim, quando não sentiam nada, entendiam que, na próxima aplicação, seria necessário aumentar a dose do pó, durante a preparação da mistura usada na pulverização.

As ameaças destes inseticidas ao meio ambiente e à saúde humana só se tornaram conhecidas durante os anos 1980, quando ecoaram, no Brasil, os resultados dos estudos de

\footnotetext{
${ }^{114} \mathrm{O} B H C$ é um inseticida criado em 1825 e usado, durante a Segunda Guerra Mundial, para combater piolhos e pulgas. O uso foi permitido no Brasil até o ano de 1985. Ele era aplicado para combater o barbeiro, responsável pela doença de Chagas, e os mosquitos transmissores da malária. $\mathrm{Na}$ agricultura, servia principalmente ao combate da broca-do-café, produzida pelo besouro negro.

${ }^{115}$ Como já foi mencionado, este dispositivo provocou a supressão de grande parte das pequenas propriedades no interior do Estado do Paraná, fator que culminou na migração de centenas de famílias de agricultores para a Amazônia.

${ }^{116}$ Termo originado a partir da sigla do inseticida $D D T$.
} 
Rachel Carson ("Primavera Silenciosa"), difundidos pelos movimentos ambientalistas. Mas, apesar de tomar conhecimento dos riscos, os agricultores só recuaram, em relação ao uso dos inseticidas, após a proibição ${ }^{117}$ da comercialização do produto ou o término dos estoques, nos anos 1980 e $1990^{118}$.

\subsection{Risco em ascensão}

Além do histórico de exposição a agrotóxicos trazidos, pelos produtores rurais, da região Sul do país, também em Alta Floresta estas populações ficaram expostas a este grupo de compostos. Os principais agrotóxicos usados nas primeiras fases da ocupação foram o $B H C$, destinado ao controle de pragas nas culturas de café, e o $D D T$, aplicado e distribuído pela SUCAM para controlar populações de mosquitos transmissores de doenças infectoparasitárias.

O último lote de $D D T$ foi aplicado no ano de 1991. Estudos indicam que em peixes do rio Teles Pires e em alguns de seus afluentes, ainda podem ser encontradas doses moderadas de resíduos do produto (DALLA VILLA et al., 2006; D'AMATO; TORRES; MALM, 2007). Isso ocorre em razão da resistência dos inseticidas, principalmente o $D D T^{119}$, à degradação natural, o que faz com que persistam nos ecossistemas por longos períodos.

Mas o problema não se restringe ao $D D T$, uma pesquisa atual, sobre a comercialização de pesticidas em Alta Floresta, realizada por Silva e colaboradores (2011), indica os herbicidas são, atualmente, o tipo de agrotóxico mais consumido na região. A quantidade chega a 145 mil quilos por ano. O Tordon (2,4-D + Picloram), que é usado principalmente para o controle de ervas invasoras em pastagens é líder de consumo. A correlação entre o volume comercializado e a área destinada à pastagem mostra que cada hectare de pastagem recebe em média 0,5 kg desse produto por ano (IBGE, 2014b; SILVA et al., 2011). As pulverizações são realizadas principalmente no período chuvoso, o que pode aumentar o risco de contaminação dos ecossistemas aquáticos.

O Tordon é classificado como nível I de uma escala de toxicidade de I a IV, definida pela Agência Nacional de Vigilância Sanitária (ANVISA, 2014b, 2014c). Ele possui extenso efeito residual no solo, o que aumenta o risco de contaminação das águas subterrâneas ou superficiais, por longos períodos (PROCÓPIO et al., 2008).

${ }^{117}$ O DDT foi retirado do mercado em duas etapas: em 1985, quando foi cancelada a autorização para uso agrícola; e em 1998, quando foi proibido o seu uso em campanhas de saúde pública. Apesar disso, o uso não foi totalmente interrompido. Na realidade, a sua fabricação, importação, exportação, manutenção em estoque, comercialização e utilização só foi controlada em 2009, quando foi sancionada a Lei 11.936 .

${ }^{118} \mathrm{O}$ uso de $B H C$ foi proibido em 1992.

${ }^{119}$ Os resíduos de $D D T$ são encontrados frequentemente no território dos EUA, até os dias de hoje, apesar de seu uso ter sido abolido nos anos 1970 (D'AMATO; TORRES; MALM, 2002). 
Além do volume de comercialização, as demais informações sobre o uso de agrotóxicos em Alta Floresta são bastante limitadas. Para se ter uma ideia, os dados do IBGE (2013) sugerem que os estabelecimentos agrícolas do município não utilizam qualquer tipo de pesticida. Contudo, algumas informações secundárias permitem melhor entender o problema. Em alguns trabalhos de conclusão de curso desenvolvidos por estudantes da UNEMAT, na região de Alta Floresta, descobriu-se que os produtores locais de hortaliças substituíram totalmente o uso do esterco bovino por fertilizantes químicos ou esterco de aves (BELTZ, 2008; LIMA, 2011; MARTINS, 2008). Segundo os produtores, a concentração de Tordon nos resíduos bovinos, coletados na região, compromete o crescimento das verduras de folhas largas, inviabilizando a produção.

\subsection{Outras fontes de contaminação ambiental por agrotóxicos}

De acordo com os dados coletados por Silva e colaboradores (2011), a contaminação ambiental por agrotóxicos, em Alta Floresta, não se restringe aos herbicidas. O volume anual de consumo de inseticidas também é considerado alto. São cerca 6.000 quilos por ano. A exposição ambiental individual a pesticidas em geral (herbicidas, inseticidas e fungicidas) pode chegar a 5,1 litros/ano ${ }^{120}$. Entre as principais vias de contaminação estão a exposição ao ar contaminado, durante a pulverização, e o consumo de água, peixes e outros alimentos contaminados.

Os produtos mais comercializados são os compostos organofosforados e os organoclorados, como o Fipronil $^{121}$ e o Endosulfan ${ }^{122}$. No que se refere ao nível de toxicidade, a maioria deles pertence à Classe I (altamente tóxicos). Eles são usados no combate a pragas em diversos tipos de plantações, incluindo hortaliças, arroz, milho, cacau, café e outras frutas.

Embora a maior parte das hortaliças consumidas no município derive de outras regiões, sobretudo do Estado do Paraná, a produção local pode ser considerada significativa. São mais de 40 hortas que abastecem supermercados e feiras livres (NESPOLI et al., 2003). É provável que um volume significativo de agrotóxicos seja destinado a esta

\footnotetext{
120 Não encontramos estudos similares que pudessem servir de comparação para clarear, por exemplo, a amplitude deste nível de exposição. Também não há limites de tolerância estabelecidos pela Organização Mundial da Saúde, como pode ser verificado para o mercúrio e as substâncias tóxicas de origem atmosférica.

${ }^{121}$ Ingrediente ativo de produtos como o Regente e o Termidor, usados no controle das principais pragas de solo e atualmente comercializados pela $B A S F$. O seu uso foi proibido na União Europeia em 2013.

122 Organoclorado vendido como Thiodan, Thionex, Phaser, Benzoepin, pelas empresas Bayer CropScience, Makhteshim Agan, Nortox S.A., entre outras. O seu uso é proibido em mais de 60 países, incluindo países da União Europeia (em 2005), do Oeste da África e da Ásia.
} 
produção. Os dados locais são escassos. Em outras regiões amazônicas, o consumo de agrotóxico tem sido verificado em 64\% a 96,7\% das hortas municipais (IBGE, 1998 apud WAICHMAN, 2008). Um dos maiores problemas associados ao uso de inseticidas em hortas, sobretudo na região amazônica, é o baixo nível de escolaridade dos produtores, o que dificulta a compreensão dos rótulos dos produtos. Além disso, segundo Waichman (2008), o treinamento dos agricultores sobre os perigos associados aos pesticidas é insuficiente.

A contaminação fluvial em largas distâncias é outro problema presente na região de Alta Floresta. Os produtos usados nas lavouras do Centro-Sul do Estado de Mato Grosso alcançam as águas por meio das chuvas e contaminam os rios que escoam em direção à Amazônia. Entre eles, está o rio Teles Pires. Não existem dados específicos sobre o índice de contaminação do rio na região de Alta Floresta. A título de conhecimento, é importante mencionar que o cálculo do consumo médio de herbicidas, inseticidas e fungicidas, em Mato Grosso, está em torno de 12L/ha para soja, 6L/ha para milho, 28L/ha para algodão e 4,8L/ha para cana-de-açúcar. Em 2010, estas cultivares consumiram cerca de 110 milhões de litros de agrotóxicos, pulverizados em 9,6 milhões de hectares de lavouras do Estado (ABRASCO, 2012). As áreas de produção se localizam no berço das principais bacias hidrográficas do Estado.

Adicionalmente, a tendente consolidação da região de Alta Floresta, como produtora de carne e leite e, gradualmente, de soja, implica no incremento do uso de agrotóxicos, como o Tordon, aplicado a pastagens, e na introdução de novos tipos, como o herbicida Glifosato, usado na produção de soja transgênica. Nesta perspectiva, observa-se que a forma que a degradação ambiental se manifesta, nos dias atuais, é potencialmente mais danosa para o ecossistema, que a degradação biofísica observada nas fases anteriores.

\subsubsection{Mercúrio}

Os mais de 10 anos de garimpo produziram danos ambientais irreversíveis. A extração e a purificação do ouro se baseavam em métodos que empregam baixíssima tecnologia, o que resultou na devastação de sistemas aquáticos e terrestres. Do ponto de vista dos impactos físicos, grandes áreas marginais aos rios e igarapés foram reviradas, principalmente por meio do uso de dragas ${ }^{123}$. Também o leito dos rios foi afetado. Profissionais da SMS/AF contaram que, em certas circunstâncias, as águas do rio Teles Pires ficavam "da cor de leite", devido à remoção de sedimentos gerada pelas dragas dos garimpos. No caso dos igarapés, comentou-se sobre o desvio de cursos d'água, gerados

\footnotetext{
${ }^{123}$ Draga é uma máquina usada para tirar a areia ou o lodo do fundo dos rios.
} 
pela exploração garimpeira, além de erosões e empobrecimento de solos, o que pode impedir, ainda hoje, a revegetação natural.

Mas, foi a contaminação química gerada pelo mercúrio que trouxe os mais sérios prejuízos aos ecossistemas. Estima-se que durante 15 anos de mineração de ouro (19801995), os garimpos de Alta Floresta tenham lançado de 2.000 a 3.000 toneladas de mercúrio nos ecossistemas do município (MALM, 1998).

$\mathrm{Na}$ percepção dos agricultores do bairro Vila Nova, as águas de igarapés e rios continuam contaminadas com o metal - identificado, por eles, como "azougo"124. Eles justificam tal afirmação pelas numerosas cavas que foram abertas nas proximidades e no interior destes corpos d'água e pela enorme quantidade de mercúrio que foi usado nestes locais. Estes fatores têm sido apontados em alguns estudos desenvolvidos no município por Hacon e colaboradores (2006). Eles comprovam que, atualmente, vinte anos após o fechamento dos garimpos, o mercúrio ainda é encontrado em moderada concentração no organismo dos peixes dos rios da região.

Diante deste quadro, é provável que as águas e peixes, desta região, apresentem contaminações de mercúrio superiores às encontradas nas demais regiões do país. Segundo Hacon e colaboradores (1997b), até o final dos anos 1990, os níveis de mercúrio encontrados nos peixes do rio Teles Pires, a fonte mais significativa de pescado para consumo local, variavam entre 0,5 a 3,6 mg por quilo de pescado. No estudo mais recente, também realizado com peixes do rio Teles Pires, a autora e sua equipe encontraram uma concentração de $0,6 \mathrm{mg} / \mathrm{kg}$, níveis que ainda estão acima do limite tolerado pela OMS $(0,3$ mg de mercúrio por pessoa) (HACON et al., 2006).

Além disso, importa mencionar que o sistema de produção de peixe, adotado atualmente em Alta Floresta, também é um fator que pesa em desfavor a exposição da população ao metal. Isso porque, em parte das pisciculturas, os peixes são produzidos em tanques que ocupam o mesmo lugar, antes explorado pelo garimpo (figura 25). Assim, se houve contaminação do ecossistema com o mercúrio, utilizado na mineração, a produção de peixes pode estar contaminada.

\footnotetext{
${ }^{124}$ Uma flexão da palavra azougue, que significa mercúrio.
} 

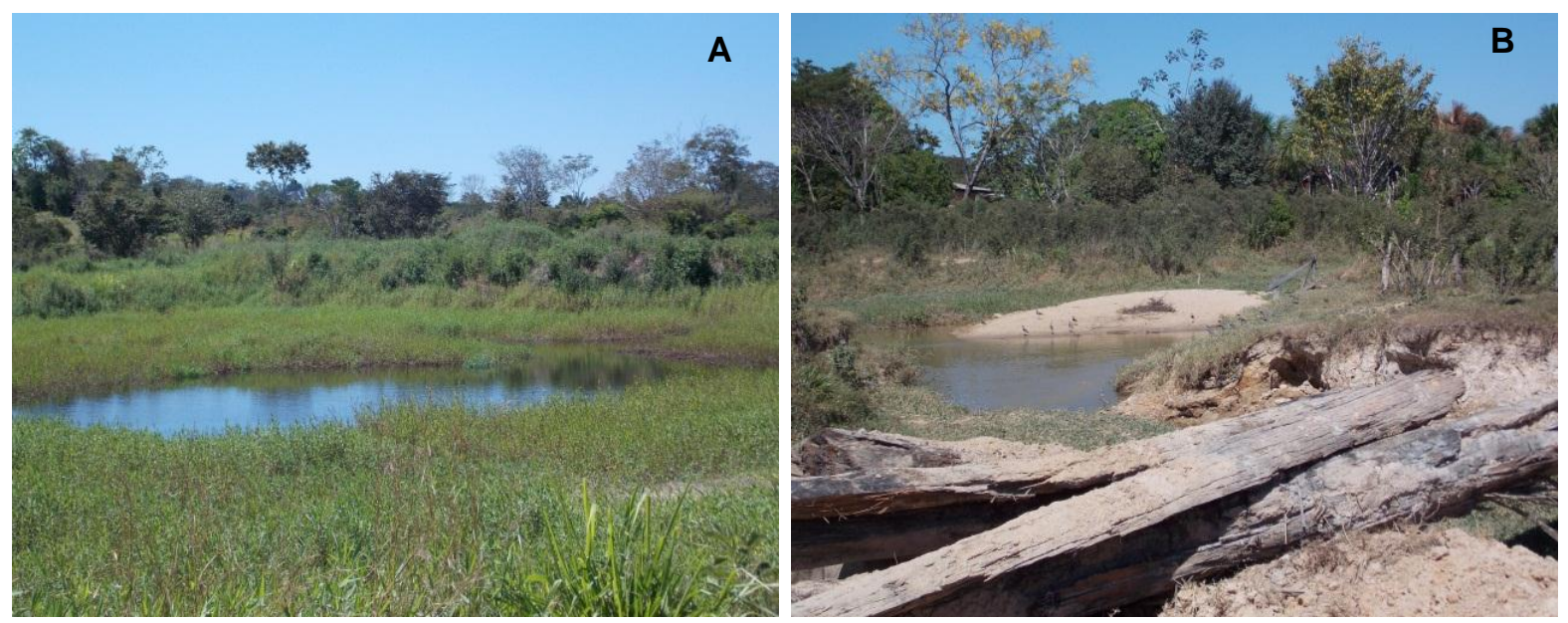

Figura 25 - Exemplo de uma antiga cava de garimpo que serve atualmente como tanque de criação de peixes. Observar, na imagem A, o tanque, e, na B, o que restou da antiga cava. Ambos os espaços situam-se, um nas adjacências do outro. Chácara Jesus Cristo é o Senhor, Alta Floresta - MT. Foto: Bianca Weihs.

Há, contudo, um aspecto que reduz o risco à contaminação humana. Trata-se de uma região produtora e consumidora de carne bovina, onde o consumo de peixe é significativamente mais baixo em outras regiões da Amazônia.

\subsubsection{O risco para as doenças crônicas}

\subsubsection{Doenças cardiovasculares: como identificar as causas?}

As interpretações dos participantes da pesquisa sobre as origens das doenças cardiovasculares são distintas. Antes de entrar nas explicações destes temas, propriamente ditas, cabe destacar os fatores que, ao que o estudo indica, interferem nestas interpretações. Observa-se, em linhas gerais, que as interpretações dos grupos sobre os determinantes e as causas destas doenças sofrem forte influência da mídia (rádio, tv, etc.) e próprio do sistema de saúde. Sob esta ótica, predominam as prerrogativas de que as doenças são produzidas, sobretudo, pelos hábitos "modernos" de consumo, isto é, de produtos industrializados.

$\mathrm{Na}$ percepção dos profissionais da SMS/AF, as principais mudanças estão na substituição de alimentos in natura, produzidos nas próprias propriedades ou adquiridos em feiras, por exemplo, por alimentos que apresentam altas concentrações de açúcar, sal e gorduras. Esta nova tendência alimentar teria importante contribuição para a emergência das doenças cardiovasculares e diabetes. Ademais, cita-se a importância do consumo de tabaco e álcool, como fatores que também influenciariam o crescimento do número de casos de cânceres, entre outras doenças. 
Sendo assim, embora a literatura reconheça a contribuição de contaminantes atmosféricos para a ocorrência de doenças cardiovasculares (DOCKERY, 2001; FARIA et al., 2006), este elemento não apareceu em nossa pesquisa. Outros fatores, como os riscos da exposição a agrotóxicos e ao mercúrio, igualmente investigados como determinantes deste tipo de enfermidade (MOSTAFALOU; ABDOLLAHI, 2013; VIRTANEN et al., 2007), também não foram citados.

O que se observa, em linhas gerais, é que os riscos tóxicos disseminados nos ecossistemas pela atividade agrícola ainda encontram pouco espaço na abordagem dos agravos cardiovasculares. No sistema de saúde, por exemplo, os hábitos "modernos" de consumo, são amplamente priorizados como determinantes destas doenças. Esta prioridade é explicada, em termos, pelos problemas encontrados, no interior das ciências, para comprovar questões de maior complexidade. Não é novidade, como citou Lessa (2004), que o que se conhece, em termos de fatores de risco para as doenças cardiovasculares, seja, ainda, insuficiente para compreender o amplo conjunto de elementos que as determina. Diante desta parcial incompreensão, a maioria dos escritos científicos sustenta a afirmação que estas doenças são determinadas por escolhas individuais (dieta rica em gorduras saturadas, com consequente aumento dos níveis de colesterol e da hipertensão, além do tabagismo, inatividade física) (ISHITANI et al., 2006; LENFANT, 2001). Percebe-se, assim, que, como o sistema de saúde se sustenta no conhecimento da ciência, também, ali, as escolhas individuais ganham ampla prioridade. Em última instância, esta escolha secundariza a importância da degradação e contaminação ambiental na determinação das doenças.

\subsubsection{Cânceres: A exposição a contaminantes ambientais e o aumento da frequência da doença}

Além da influência da mídia e do sistema de saúde, percebe-se que as interpretações dos participantes dos grupos focais sofrem, também, a influência de equipes de pesquisadores $^{125}$ que passam pela região, desde a década de 1990, desenvolvendo pesquisas da área da saúde ambiental. São projetos que se dedicam, sobretudo: (i) à concentração de mercúrio nos ecossistemas e na fauna piscívora ${ }^{126}$, e (ii) à poluição

\footnotetext{
${ }^{125}$ De instituições como a FIOCRUZ, do Rio de Janeiro, a UNEMAT, a USP (Universidade de São Paulo) ou a UFRJ (Universidade Federal do Rio de Janeiro).

${ }^{126}$ Estes estudos foram realizados principalmente pela equipe da pesquisadora Sandra Hacon, da Fiocruz do Rio de Janeiro. Ela pesquisa a epidemiologia do mercúrio na região desde os anos 1990, quando defendeu a tese de doutorado sobre o risco potencial do mercúrio, usado nos garimpos de Alta Floresta, para a saúde humana.
} 
atmosférica, gerada pelas queimadas, e sua relação com as doenças respiratórias ${ }^{127}$. Em menor grau de importância, em termos de percepção pública local, encontram-se algumas pesquisas sobre o índice de contaminação de peixes do rio Teles Pires com $D D T^{128}$.

De forma geral, observa-se que os principais problemas crônicos de saúde da fase atual do avanço da fronteira são provocados principalmente pela exposição a contaminantes ambientais. Nesta perspectiva foram citados pelos participantes dos grupos focais principalmente a exposição: (i) ao mercúrio, lançado nos ecossistemas pelos garimpos de ouro, e (ii) aos agrotóxicos, usados desde a época em que os agricultores ainda trabalhavam nas lavouras de café do Estado do Paraná, até os dias atuais, quando os aplicam, em maior parte, nas pastagens.

Eles acreditam que o alto número de caso de cânceres, destacado, também, por alguns médicos da região ${ }^{129}$, se deve principalmente à exposição ao mercúrio. O metal estaria sendo veiculado pelos alimentos, principalmente o peixe e a água. A contaminação humana ocorreria, segundo esta interpretação, desde a época do garimpo à fase atual.

Para melhor compreender este fenômeno é valioso resgatar o conhecimento que se possui hoje sobre esta temática. Em termos gerais, os efeitos da exposição laboral ao mercúrio são bastante discutidos na literatura. Tais discussões ampliaram o conhecimento da relação entre a exposição direta ao metal e os efeitos à saúde. Entretanto, quanto à exposição ambiental, ou seja, indireta - que se dá por meio do consumo de alimentos e água contaminados com o mercúrio - se sabe bem menos. É consenso, entre os pesquisadores da área, que são tardias as consequências de maior importância à saúde (CRESPO-LÓPEZ et al., 2005). Por exemplo, no caso da intoxicação por mercúrio na baía de Minamata, Japão, citada no capítulo quatro, os efeitos à saúde só começaram a aparecer após 18 anos. O pico epidêmico, ou seja, a fase de maior diagnóstico das consequências à saúde, só se manifestou 28 anos mais tarde (VERAS; ARAÚJO, 1998).

Além de ser tardio, é importante relembrar que os efeitos do mercúrio à saúde são sistêmicos e, por estas razões, as pesquisas encontram dificuldades em correlacioná-los

\footnotetext{
${ }^{127}$ Neste caso, há pesquisas que trataram apenas da poluição atmosférica, como as que são desenvolvidas pela equipe do pesquisador Paulo Artaxo, da USP, e a pesquisas que relacionam estas emissões com a saúde da população. Neste último caso, tem importância os trabalhos da pesquisadora da UNEMAT (Campus de Cáceres), Eliane Ignotti, em parceria com estudiosos da Fiocruz, como Cleber Nascimento do Carmo, Beatriz Fátima Alves de Oliveira e Washington Leite Junger, entre outros.

${ }^{128}$ Orientadas pelo pesquisador Olaf Malm, da Universidade Federal do Rio de Janeiro.

${ }^{129}$ Nas narrativas aparecem informações de interpretações individuais de dois médicos de Alta Floresta, provindos, um do Rio de Janeiro e o outro, de Belo Horizonte. Os médicos compararam a incidência de cânceres nesta região, com a que conheciam na região de sua procedência. Eles acreditam que a explicação para a forte incidência da doença na região seja a alta exposição aos vapores do mercúrio, durante a fase de garimpo, e aos resíduos deste metal concentrados nos alimentos e na água, consumidos atualmente.
} 
com a contaminação alimentar, por exemplo. O que se sabe é que as pessoas que consomem alimentados com alto teor de mercúrio podem sofrer alguns efeitos mutagênicos (BOFFETTA; MERLER; VAINIO, 1993). Além disso, recentemente, a toxicidade mediada pelo mercúrio, tem sido associada a doenças como Alzheimer, Parkinson, autismo, lúpus, esclerose lateral amiotrófica, entre outras (ZAHIR et al., 2005).

Nestes termos, o que se observa é que o aumento das doenças crônicas, em Alta Floresta, pode ter, entre outras causas, a significativa contaminação ambiental por mercúrio, já observada por diversos estudos (HACON, 2000; HACON et al., 1997b, 2006; MALM, 1998) e amplamente citada pelos participantes dos grupos focais. Esta contaminação teria relação com o amplo consumo do metal nos garimpos de ouro. Há, contudo, alguns estudos desenvolvidos na região do médio rio Tapajós, Estado do Pará, que indicam que a concentração de mercúrio encontrada nas águas e nos organismos de peixes da Amazônia pode decorrer, também, da mobilização do metal, natural dos solos, por atividades agrícolas (GUIMARÃES; MERGLER, 2011; ROULET et al., 1998, 1999). A confirmação deste fenômeno, em Alta Floresta, dependerá de estudos específicos.

O crescente número de casos de cânceres na região também é associado ao extensivo uso de agrotóxicos. Os compostos contaminariam os trabalhadores durante a pulverização e afetariam, em menor grau, a saúde dos consumidores de produtos como verduras e legumes. Esse conhecimento é disseminado na região, mas encontra poucas provas científicas, uma vez que há significativa carência de estudos sobre a relação entre a exposição a agrotóxicos e o desenvolvimento de tumores cancerígenos.

Mesmo em Mato Grosso, Estado considerado o maior consumidor nacional de pesticidas do país (ABRASCO, 2012), as pesquisas são bastante escassas. Um dos poucos estudos sobre o tema foi realizado por Curvo, Pignatti e Pignati (2013). Eles fizeram a comparação entre os indicadores de morbidade e mortalidade por câncer na faixa etária de 0 a 19 anos e o uso de agrotóxicos no Estado, de 2000 a 2006. Neste intervalo, o uso de agrotóxicos apresentou incremento de $89,10 \%$ e a mortalidade de jovens com câncer aumentou de 2,97\% para 3,76\%. Embora pareçam reduzidos, esses resultados indicam que a exposição a agrotóxicos, desde o nascimento, tem relação estatisticamente significante com o adoecimento e a morte de crianças e jovens por câncer.

Embora restem várias lacunas no conhecimento, a percepção dos participantes da pesquisa é a de que o mercúrio, em primeiro lugar, e os agrotóxicos, em segundo, sejam os principais fatores de risco para os diferentes tipos de câncer. Neste sentido, cita-se, sobretudo, o $D D T$ e o $B H C$, aplicados nas fases iniciais da ocupação, e o Tordon, atualmente usado no controle de ervas invasoras em pastagens. Acredita-se, além disso, que o acúmulo de pesticidas nos ecossistemas e no organismo humano, não traz apenas 
riscos de aumento no número de casos de cânceres, na fase atual, como está relacionado o aumento futuro de sua prevalência na população.

De forma sintética, os resultados da pesquisa sobre a relação entre degradação e contaminação ambiental, fatores de risco e doenças, na fronteira de Alta Floresta, podem ser observados no quadro 2. O esforço para comprimir tais informações em um espaço único teve como objetivo exclusivo melhorar a visualização destes resultados. Toda a discussão é encontrada nos textos que precedem esta apresentação.

Quadro 2. Síntese da relação entre degradação/contaminação ambiental, risco e doenças, observada na fronteira de Alta Floresta. Fonte: Pesquisa de campo, março de 2013 e agosto de 2014

\begin{tabular}{|c|c|c|}
\hline $\begin{array}{l}\text { Degradação e } \\
\text { contaminação } \\
\text { ambiental }\end{array}$ & Fatores de risco & Doenças \\
\hline Desmatamento & $\begin{array}{l}\text { - Maior exposição humana ao mosquito } \\
\text { vetor. } \\
\text { - Aumento da população de mosquitos. }\end{array}$ & - Malária \\
\hline Queimadas & $\begin{array}{l}\text { - Exposição humana a partículas tóxicas } \\
\text { presentes na fumaça. }\end{array}$ & $\begin{array}{l}\text { - Doenças } \\
\text { respiratórias }\end{array}$ \\
\hline Mercúrio & $\begin{array}{l}\text { - Exposição a vapores, nas áreas de } \\
\text { mineração de ouro. } \\
\text { - Exposição prolongada a resíduos } \\
\text { acumulados nos ecossistemas. }\end{array}$ & $\begin{array}{l}\text { - Uma série de } \\
\text { doenças crônicas e } \\
\text { degenerativas. }\end{array}$ \\
\hline Agrotóxicos & $\begin{array}{l}\text { - Exposição durante a pulverização. } \\
\text { - } \quad \text { Exposição prolongada a resíduos } \\
\text { acumulados nos ecossistemas. } \\
\text { - Exposição a alimentos e água } \\
\text { contaminados. }\end{array}$ & $\begin{array}{l}\text { - Uma série de } \\
\text { doenças crônicas e } \\
\text { degenerativas. }\end{array}$ \\
\hline
\end{tabular}

\section{Conclusão}

Os resultados da pesquisa mostram que à medida que avançou a ocupação da fronteira, aumentou a contaminação do meio ambiente com substâncias tóxicas, sobretudo os agrotóxicos e o mercúrio. A alta persistência destes compostos nos ecossistemas contribuiu para eles ficassem disponíveis ao consumo humano por um espaço maior de tempo. Somado a isso, o longo tempo de exposição dos trabalhadores contribuiu para que aumentasse a concentração dessas substâncias no organismo.

No caso de Alta Floresta, as famílias de agricultores já sofriam a exposição a agrotóxicos desde que trabalhavam na produção de café, no Estado do Paraná. No cenário atual, a tendência é de aumento da concentração de resíduos destes compostos nos ecossistemas. Muito embora, vale ressaltar, aos poucos, os produtos utilizados estejam 
sofrendo modificações no que tange ao nível de toxicidade e de agressão ao organismo (os organoclorados, altamente tóxicos e persistentes, por exemplo, foram banidos ou reformulados). O risco à saúde pode estar no consumo de alimentos e água contaminados e na exposição dos trabalhadores e demais populações, aos vapores emitidos durante a pulverização.

Além disso, as famílias de agricultores conheceram a explosão do uso de mercúrio nos garimpos, ainda na primeira fase da ocupação da região, no final dos anos 1970 . Nos dias de hoje, embora possa estar reduzindo, persiste a exposição da população à alta/moderada concentração deste metal pesado nos ecossistemas. O fator de risco se revela, neste caso, no consumo de peixes de hábitos carnívoros.

Nesta fase de envelhecimento da população de Alta Floresta, a carga individual de exposição ambiental, conhecida desde a primeira idade, somada ao nível de toxicidade e persistência destes compostos no organismo humano, afeta, de maneira diferente, o organismo dos indivíduos. Uma série de outros fatores, como os imunológicos, genéticos, sociais e culturais, contribuem para que cada caso de adoecimento seja um caso específico. De forma coletiva, contudo, a determinação das doenças crônicas atuais tem, entre outros fatores, a escolha - ou a permissão - do uso de substâncias altamente tóxicas e persistentes no ambiente e no organismo humano. 


\section{CONSIDERAÇÕES FINAIS}

Este estudo buscou compreender como a degradação ambiental associada à ocupação agrícola afetou a saúde da população da fronteira de Alta Floresta. A pesquisa foi orientada por duas questões: No curso do avanço da fronteira agrícola, como a degradação ambiental afetou a saúde da população local? Sob o ponto de vista da saúde pública, quais são as tendências atuais desta fronteira?

A primeira hipótese era de que a emergência das doenças de maior importância em termos de saúde pública, nesta fronteira, foi determinada, entre outros fatores, pela degradação do meio ambiente. Para confirmar esta proposição, analisamos a relação entre as formas de uso e ocupação do espaço, as formas de degradação ambiental e as mudanças no perfil epidemiológico local.

Na perspectiva ambiental, verificou-se que, ao longo do avanço da ocupação agrícola, a degradação biofísica, principalmente na forma de desmatamento e queimadas, foi sendo substituída pela contaminação tóxica do meio ambiente. Atualmente, os agrotóxicos, sobretudo os herbicidas usados na produção de pastagens e soja, estão entre os fatores de maior agressão aos ecossistemas. A eles se soma o acúmulo de mercúrio no ambiente, originado, de uma parte, nos garimpos de ouro dos anos 1980 e 1990 e, de outra, como sugerem alguns estudos, no próprio solo do ecossistema amazônico, de onde o metal vem sendo removido pelo desmatamento, as queimadas e a mecanização agrícola.

As similaridades encontradas, entre estas formas de degradação ambiental e as mudanças no perfil epidemiológico, destacam a importância do meio ambiente para a definição desse perfil, na fronteira. Nesse sentido, vale notar que no quadro de transição das doenças, aqui observado, a emergência das novas doenças está associada, sobretudo, à degradação do meio ambiente. Exemplo deste fenômeno é a manifestação da malária, em um contexto de amplo desmatamento, das doenças respiratórias agudas, no período de maior incidência de queimadas, e das doenças crônicas, na fase atual, de acúmulo de produtos tóxicos nos ecossistemas e de prolongado período de exposição humana a estas substâncias. Em síntese, estas questões confirmam a primeira hipótese do estudo.

Além disso, destacamos que, além do fator ambiental, propriamente dito, a emergência das doenças, nesta região, sofreu influências de fatores como o envelhecimento da população e as mudanças nos hábitos de consumo. Sob o ponto de vista do envelhecimento, percebeu-se que não foi o fenômeno, por si próprio, que definiu o perfil epidemiológico. Mas, ele foi determinante por prolongar o tempo de exposição da população, essencialmente rural, às substâncias tóxicas associadas à agricultura. Nesta 
perspectiva, os resultados mostraram que, em síntese, o atual quadro de emergência e manutenção das doenças crônicas se deve, em primeiro plano, à quantidade, qualidade e diversidade de substâncias tóxicas, depositadas nos ecossistemas, e, em segundo, ao prolongado período de exposição individual a estas substâncias.

No que tange aos hábitos, destacamos a importância do processo de urbanização da fronteira. Ele transferiu as escolhas, em termos de qualidade dos produtos, por exemplo, da dimensão da produção para a dimensão do consumo. Neste processo, ganharam importância os alimentos industrializados (ricos em gorduras, sal, açúcar, etc.), enquanto diminuiu a preocupação dos agricultores quanto à origem de produtos (carnes, peixes, frutas, hortaliças, etc.).

Em linhas gerais, estes problemas foram potencializados pela dificuldade de percepção individual dos riscos. Embora o conhecimento sobre a contaminação ambiental por mercúrio ou por herbicidas esteja disseminado na região, ele pouco influencia os hábitos da população. Tal aspecto também se reconhece no sistema de saúde. Numa perspectiva mais abrangente, a pesquisa nos mostrou que as estratégias de atuação do setor em relação à exposição a contaminantes ambientais são insuficientes. A exposição a agrotóxicos, por exemplo, raramente é tema de discussão no interior do sistema. Quando o é, as preocupações centram-se em aspectos agudos, como a intoxicação. Por consequência, o sistema de saúde local pouco contribui para a difusão e minimização dos efeitos crônicos à saúde da alta e/ou prolongada exposição a contaminantes ambientais.

Diante das dificuldades do sistema de saúde em reduzir os níveis de exposição da população ao risco, a perspectiva mais relevante, em termos de controle das enfermidades associadas aos contaminantes tóxicos, foi a intensificação da fiscalização ambiental. Neste sentido, notou-se, por exemplo, que a pressão dos órgãos ambientais em favor da redução das taxas de desmatamento e queimadas teve um papel preponderante na queda das taxas de internação por doenças respiratórias agudas. Trata-se de ações intersetoriais que nem sempre são destacadas no âmbito das políticas públicas.

Outro aspecto importante, revelado pelo estudo, diz respeito à fase atual do avanço da fronteira em Alta Floresta. Partindo da perspectiva oferecida pela saúde pública, notou-se que esta fronteira se encontra em um estágio avançado de integração ao território nacional. Neste processo, há uma perda significativa das especificidades da fronteira, que joga a favor da melhoria da qualidade de vida da população. A fronteira termina, em termos de saúde pública, ao se consolidar como geradora de serviços e tecnologias que a colocam numa posição similar às demais regiões do país.

Tais resultados confirmam a segunda hipótese do estudo. Como perspectiva, a fronteira agrícola é, então, concebida como um movimento de apropriação de terras e de 
recursos naturais, viabilizado e subsidiado pelo Estado e colocado em prática por diversos grupos sociais, dotados de distintos interesses e necessidades. Em Alta Floresta, este movimento se expande no espaço e no tempo. No espaço, à medida que novas áreas são incorporadas, e no tempo, na medida em que a fronteira vai se transformando, da fase de ocupação à fase de consolidação. Em ambos os casos, põe-se em curso um importante processo de transformação do meio natural (degradação ambiental), que determina, em conjunto com outros fatores, o perfil epidemiológico.

No que concerne aos limites da pesquisa, sentimos falta de uma possibilidade de aproximação, mais consistente, das percepções dos grupos sociais com os resultados da pesquisa epidemiológica. Além disso, a pesquisa foi afetada pela escassez de dados oficiais no campo da saúde pública, sobretudo nos períodos anteriores aos anos 1990. Este obstáculo limitou as análises em termos de corroboração dos resultados com outros indicadores.

Do ponto de vista de pesquisas complementares, três aspectos, em especial, merecem ser aprofundados. O primeiro refere-se à relação entre a exposição a contaminantes ambientais e as doenças tardias. O segundo diz respeito à criação de indicadores de risco, que subsidiem as ações do sistema de saúde em regiões de fronteira. O terceiro, por sua vez, aponta a importância do estudo da história de vida dos doentes, bem como, da representação social da relação meio ambiente e saúde, como perspectivas para abordar algumas das doenças cada vez mais comuns entre agricultores, como o mal de Alzheimer e a doença de Parkinson.

Vale ressaltar, neste sentido, a pertinência do método empregado no estudo. Apesar de termos notado algumas limitações, no que concerne, por exemplo, à definição dos participantes e a distinção do conhecimento, entre mitos e símbolos pouco compreendidos, temos alguns pontos positivos a destacar. A associação entre as técnicas de grupo focal e a linha do tempo ajudou a compreender alguns aspectos que estariam fora do escopo de outras perspectivas metodológicas. A abordagem sistêmica do problema, incluindo a noção de tempo, é um exemplo desta questão. Neste sentido, sugerimos que outros estudos contribuam no sentido de adaptar o método a outras escalas e contextos.

Além disso, o estudo nos apontou, como perspectiva, algumas mudanças em termos de produção e exposição aos riscos. De um lado, percebemos que o controle do conjunto de doenças crônicas, nesta fronteira, depende de uma reconfiguração dos sistemas de produção agrícola. Destaca-se, neste aspecto, a necessidade de maior eficiência na gestão do consumo de agrotóxicos. Este mecanismo tem potencial para reduzir a cronicidade e irreversibilidade dos produtos agrícolas nos ecossistemas. Além disso, notamos que é significativamente importante manter o controle sobre a exploração de novas terras 
amazônicas. Trata-se de uma estratégia que, à priori, limita a contaminação dos ecossistemas com mercúrio.

De outro lado, salientamos a importância da inclusão de novas orientações no sistema de saúde, que levem em conta a distinção dos riscos contemporâneos, em termos de invisibilidade, cronicidade e irreversibilidade. Estas ações podem ser incluídas na Estratégia Saúde da Família (ESF). Há de se considerar, contudo, que elas demandam uma abordagem diferenciada.

De forma conclusiva, destacamos que o fator de maior importância, em termos de determinação dos riscos à saúde, durante o avanço da fronteira, não foi o processo de ocupação, em si. Mas, a forma com que ele foi concebido e conduzido. Neste sentido, vale salientar a escolha do governo brasileiro pelo pacote tecnológico produzido pela "Revolução Verde" (uso de agrotóxicos, sementes melhoradas, insumos, mecanização agrícola, etc.). $\mathrm{Na}$ fronteira de Alta Floresta, este pacote determinou, inicialmente, o investimento desmesurado em desmatamento e queimadas e está associado, atualmente, à disseminação do uso de agrotóxicos. A saúde da população, neste contexto, teve como pano de fundo o modelo de desenvolvimento adotado, constituído de uma lógica espoliadora do meio ambiente, que não leva em conta os problemas emergentes. 


\section{REFERÊNCIAS BIBLIOGRÁFICAS}

ABRAMOVAY, R. Desenvolvimento sustentável: qual a estratégia para o Brasil? Novos Estudos - CEBRAP, n. 87, p. 97-113, jul. 2010.

ABRASCO. Dossiê ABRASCO 1 - Um alerta sobre os impactos dos agrotóxicos na saúde. ABRASCO, , 2012.

ABREU SÁ, T. D. et al. Queimar ou não queimar? De como produzir na Amazônia sem queimar. Revista USP, v. 72, p. 90-97, 20072006.

ADI. World Alzheimer Report - 2009. London: Alzheimer's Disease International, 2009.

ALBALADEJO, C. et al. La construction du territoire sur les fronts pionniers. Tendances d'évolution et actions de développement sur les sites de Marabá (Amazonie) et de Missiones (Argentine). In: ALBALADEJO, C.; TULET, J.-C. (Eds.). Les fronts pionniers de l'Amazonie brésilienne: la formation de nouveaux territoires. Paris: L'Harmattan, 1996. p. 247-278.

ALBALADEJO, C.; ARNAULD DE SARTRE, X. (EDS.). L’Amazonie brésilienne et le développement durable: expériences et enjeux en milieu rural. Paris: L'Harmattan, 2005.

ALET, B.; DESAILLY, B.; VERGNOLLE-MAINAR, C. L'environnement: une nouvelle forme de rapports entre l'homme et la nature. In: VERGNOLLE-MAINAR, C.; DESAILLY, B. (Eds.). Environnement et sociétés : territoires, risques, développement, éducation. Grenoble: CRDP Midi-Pyrénées, 2005. p. 1-39.

ALMEIDA, C. S. Possibilidades ou limites da memória dos jovens: a história oral e a técnica metodológica Grupos Focais. Métis: história \& cultura, v. 8, n. 15, p. 103-120, 2009.

ALMEIDA FILHO, N. DE. A problemática teórica da determinação social da saúde (nota breve sobre desigualdades em saúde como objeto de conhecimento). Saúde em Debate, v. 33, n. 83, p. 349-370, 2009.

ALMEIDA FILHO, N. O que é saúde?. Rio de Janeiro: FIOCRUZ, 2011.

ALTA FLORESTA. Agenda 21 local de Alta Floresta: Planejando um futuro sustentável. Alta Floresta: Prefeitura Municipal de Alta Floresta, Fundo Nacional do Meio Ambiente, Ministério do Meio Ambiente, Governo Federal, 2008.

ANVISA. Índice monográfico: Glifosato. Disponível em: <http://portal.anvisa.gov.br/wps/wcm/connect/6e400500474594899c26dc3fbc4c6735/G01.pd f?MOD=AJPERES>.

ANVISA. Índice monográfico: Picloram. Disponível em: <http://portal.anvisa.gov.br/wps/wcm/connect/77bdb60047458cae95cad53fbc4c6735/P07++ Picloram.pdf?MOD=AJPERES $>$. 
ANVISA. Índice monográfico: 2,4-D. Disponível em: <http://portal.anvisa.gov.br/wps/wcm/connect/bdea3b804745780e857bd53fbc4c6735/D27++ 24-D.pdf?MOD=AJPERES>.

ARAÚJO, R. T. O movimento da Boa Nova. Belo Horizonte: Editora O Lutador, 1999. ARNAULD DE SARTRE, X. Fronts pionniers d'Amazonie. Paris: CNRS Editions, 2006. ARTAXO, P. et al. Química atmosférica na Amazônia: a floresta e as emissões de queimadas controlando a composição da atmosfera amazônica. Acta Amazonica, v. 35, n. 2, p. 185-196, jun. 2005.

ARVOR, D. Étude par télédétection de la dynamique du soja et de l'impact des précipitations sur les productions au Mato Grosso (Brésil). Thèse de doctorat de géographie-Rennes: Université Rennes 2 Haute-Bretagne, 2009.

ASCHERIO, A. et al. Pesticide exposure and risk for Parkinson's disease. Annals of Neurology, v. 60, n. 2, p. 197-203, ago. 2006.

ATANAKA-SANTOS, M. et al. Comportamento epidemiológico da malária no Estado de Mato Grosso, 1980-2003. Revista da Sociedade Brasileira de Medicina Tropical, v. 39, n. 2, p. 187-192, 2006.

AUBERTIN, C. Mouvements de populations et changements économiques dans le CentreOuest brésilien. Cah. Sci. Hum., v. 26, n. 3, p. 327-42, 1990.

AUGUSTO, L. G. DA S. Saúde e vigilância ambiental: um tema em construção. Epidemiologia e Serviços de Saúde, v. 12, n. 4, p. 177-187, 2003.

BARATA, R. B. Malária no Brasil: panorama epidemiológico na última década. Cadernos de Saúde Pública, v. 11, n. 1, p. 128-136, 1995.

BARATA, R. B. Como e por que as desigualdades sociais fazem mal à saúde. Rio de Janeiro: Fiocruz, 2009.

BARBIERI, A. F. População, uso da terra e prevalência de malária na Amazônia Brasileira. In: HOGAN, D. J. (Ed.). Dinâmica populacional e mudança ambiental: cenários para o desenvolvimento brasileiro. Campinas: Núcleo de Estudos de População-Nepo/Unicamp, 2007. p. $145-64$.

BARBIERI, A. F.; SAWYER, D. O. Heterogeneity of malaria prevalence in alluvial gold mining areas in Northern Mato Grosso State, Brazil. Cadernos de Saúde Pública, v. 23, n. 12, p. 2878-2886, dez. 2007.

BARCELLOS, C. et al. Mudanças climáticas e ambientais e as doenças infecciosas: cenários e incertezas para o Brasil. Epidemiol. Serv. Saúde, v. 18, n. 3, p. 285-304, 2009. BAUER, M. W.; GASKELL, G. Pesquisa qualitativa com texto: imagem e sam : urn manual pratico. Traducao P A Gareschi. Petrópolis: Vozes, 2002. 
BECKER, B. K. Amazônia: nova geografia, nova política regional e nova escala de ação. In: COY, M.; KOHLHERPP, G. (Eds.). Amazônia sustentável: desenvolvimento sustentável entre políticas públicas, estratégias inovadoras e experiências locais. Rio de Janeiro: Garamond, 2005b. p. 23-44.

BECKER, B. K. Geopolítica da Amazônia. Estudos Avançados, v. 19, n. 53, p. 71-86, 2005a.

BECKER, B. K. Fronteira e Urbanização Repensadas. Revista Brasileira de Geografia, v. 47, n. 3-4, p. 357-371, 1985.

BECKER, B. K. Significância contemporânea da fronteira: uma interpretação geopolítica a partir da Amazônia Brasileira. In: AUBERTIN, C. (Ed.). Fronteiras. Brasília: Editora UnB, 1988. p. 60-89.

BECKER, B. K. Amazônia. São Paulo: Ática, 1990.

BECKER, B. K. Revisão das políticas de ocupação da Amazônia: é possível identificar modelos para projetar cenários? Parcerias estratégicas, v. 12, p. 135-159, 2001.

BECKER, B. K. Amazônia: geopolítica na virada do III milênio. Rio de Janeiro: Garamond, 2009.

BECK, Ü. Sociedade de risco: Rumo a uma outra modernidade. São Paulo: Ed. 34, 2010.

BELTZ, L. Análise parasitológica em hortaliças de três hortas orgânicas no município de Paranaíta - MT. Trabalho de Conclusão de Curso-Alta Floresta: Universidade do Estado de Mato Grosso, 2008.

BENTES, R. A intervenção do ambientalismo internacional na Amazônia. Estudos Avançados, v. 19, n. 54, p. 225-240, ago. 2005.

BERGER, P. L.; LUCKMANN, T. Construção social da realidade: tratado de sociologia do conhecimento. Tradução Floriano de Souza Fernandes. Petrópolis: Vozes, 1995.

BERNASCONI, P.; ADAB, R.; MICOL, L. Diagnóstico ambiental do município de Alta Floresta - MTICV, , 2008.

BERTALANFFY, L. V. Teoria geral dos sistemas. Petrópolis: Ed. Vozes, 1975.

BOFFETTA, P.; MERLER, E.; VAINIO, H. Carcinogenicity of mercury and mercury compounds. Scandinavian Journal of Work, Environment \& Health, v. 19, n. 1, p. 1-7, fev. 1993.

BÖHLKE, M. Imunossupressão induzida pela malária: existe um papel para o óxido nítrico?

Rev. bras. alergia imunopatol, v. 22, n. 6, p. 173-178, 1999.

BONINI, I.; PESSOA, M. J. G.; SEABRA JUNIOR, S. Faces da produção agrícola na Amazônia mato-grossense: tipos de exploração, origem dos agricultores e impactos na 
conservação ambiental em Alta Floresta (MT). Novos Cadernos NAEA, v. 16, n. 1, p. 173190, 2013.

BOUDOU, A. et al. Les chercheurs d'or et la pollution par le mercure en Guyane française : conséquences environnementales et sanitaires. Environnement, Risques \& Santé, v. 5, n. 3, p. $167=179,2006$.

BRANDO, P. M. et al. (EDS.). Ecology, economy and management of an agroindustrial frontier landscape in the Southeast Amazon: papers of a theme issue. [s.l: s.n.].

BRASIL. Discurso do Deputado Gilson de Barros (MDB/MT)Diário do Congresso Nacional, de setembro de 1979. Disponível em: <http://imagem.camara.gov.br/lmagem/d/pdf/DCD15SET1979.pdf>. Acesso em: 26 nov. 2014

BRASIL. Estudos do Componente Indígena das UHE São Manoel e Foz do Apiacás Revisão e complementação. Empresa de Pesquisa Energética (EPE), 2001.

BRASIL. Estudo propositivo: Território Portal da Amazônia. Ministério do Desenvolvimento Agrário/Fundação Cândido Rondon, 2005.

BRASIL. Territórios da Cidadania: Proposta do Ministério do Desenvolvimento Agrário para Redução da Desigualdade Social no Meio Rural Brasileiro. Brasília: Ministério do Desenvolvimento Agrário/Secretaria de Desenvolvimento Territorial, 2007a.

BRASIL. Assistência de Média e Alta Complexidade no SUS. Conselho Nacional de Secretários de Saúde (CONASS), 2007b.

BRASIL. Informações Cadastro Único. Disponível em: <http://www.mds.gov.br/adesao/mib/matrizview.asp?|BGE=5100250>.

BRASIL. Política Nacional de Atenção Básica. Ministério da Saúde. Secretaria de Atenção à Saúde. Departamento de Atenção Básica, 2012.

BRASIL. Situação epidemiológica da malária no Brasil, 2000 a 2011: Boletim epidemiológico. Brasília: Secretaria de Vigilância em Saúde - Ministério da Saúde, 2013a.

BRASIL. Oncologia: Brasil deverá registrar cerca de 580 mil casos de câncer em 2014.

Disponível em: <http://portalsaude.saude.gov.br/index.php/cidadao/principal/agenciasaude/noticias-anteriores-agencia-saude/6898->.

BRASIL. Estimativa 2014: Incidência de Câncer no Brasil. Instituto Nacional de Câncer José Alencar Gomes da Silva. Disponível em: <http://www.inca.gov.br/estimativa/2014/index.asp?ID=2>.

BRASIL, M. DE M. E E. Avaliação ambiental integrada da bacia hidrográfica do rio Teles Pires. Brasília: EPE - Empresa de pesquisa energética, 2009. 
BRASIL; OPAS. Doenças relacionadas ao trabalho: Manual de Procedimentos para os Serviços de Saúde. Brasília: Ministério da Saúde do Brasil/Organização Pan-Americana da Saúde/Brasil, 2001.

BREILH, J. et al. Floriculture and the health dilemma: Towards fair and ecological flower production. In: BREILH, J. (Ed.). . Latin American health watch: Alternative Latin American Health Report. Cuenca: Global Health Watch, 2005. p. 70-83.

BREILH, J. Epidemiologia crítica: ciência emancipadora e interculturalidade. Rio de Janeiro: FIOCRUZ, 2006.

BREILH, J. Pilhagens, ecossistemas e saúde. In: MIRANDA, A. C. DE et al. (Eds.). . Território, ambiente e saúde. Rio de Janeiro: FIOCRUZ, 2008.

BURSZTYN, M. Alguns temas de questão setentrional: contribuição ao debate sobre um projeto para a Amazônia brasileira. In: SAYAGO, D.; TOURRAND, J.-F.; BURSZTYN, M. (Eds.). Amazônia: cenas e cenários. Brasília: UnB, 2004. p. 295-319.

BURSZTYN, M. A. A.; BURSZTYN, M. Desenvolvimento sustentável: biografia de um conceito. In: NASCIMENTO, E.; VIANNA (Eds.). Economia, meio ambiente e comunicação. Rio de Janeiro: Garamond, 2006. p. 54-67.

BURSZTYN, M.; BURSZTYN, M. A. A. Fundamentos de política e gestão ambiental: caminhos para a sustentabilidade. Rio de Janeiro: Garamond Universitária, 2012.

CABANES, P.-A.; ROUSSEL, I. Santé et environnement. In: Développement durable et territoire. Villeneuve-d'Ascq: Septentrion Presses Universitaires, 2010. p. 351-61.

CAHETÉ, F. L. S. A extração do ouro na Amazônia e suas implicações para o meio ambiente. Novos Cadernos NAEA, v. 1, n. 2, p. 134-158, 1998.

CAMARGO, E. P. Malária, maleita, paludismo. Cienc. Cult. [online], v. 55, n. 1, p. 26-29, 2003.

CAPONI, S. Georges Canguilhem y el estatuto epistemológico del concepto de salud. História, Ciências, Saúde-Manguinhos, v. 4, n. 2, out. 1997.

CARLINI-COTRIM, B. Potencialidades da técnica qualitativa grupo focal em investigações sobre abuso de substâncias. Revista de Saúde Pública, v. 30, n. 3, jun. 1996.

CARMO, C. N. et al. Queima de biomassa e doenças respiratórias na região amazônica: Uma aplicação de modelos aditivos generalizados. XLI SBPO 2009. In: XLI SIMPÓSIO BRASILEIRO DE PESQUISA OPERACIONAL. Porto Seguro: SOBRAPO, 2009 CARMO, C. N. DO et al. Mortalidade por doenças cardiorrespiratórias em idosos no estado de Mato Grosso, 1986 a 2006. Revista de Saúde Pública, v. 44, n. 6, p. 1112-1119, dez. 2010. 
CARMO, E. H.; BARRETO, M. L.; SILVA JR, J. B. Mudanças nos padrões de morbimortalidade da população brasileira: os desafios para um novo século. Epidemiol. Serv. Saúde. [online], v. 12, n. 2, p. 63-75, 2003.

CARNEIRO, F. F.; RIGOTTO, R. M.; PIGNATI, W. Frutas, cereais e carne do sul: agrotóxicos e conflitos ambientais no agronegócio no Brasil. e-cadernos CES, v. 17, p. 1030, 2012.

CARSON, R. Primavera silenciosa. São Paulo: Edições Melhoramentos, 1962.

CARTA CAPITAL. Acabou a farra. Os países pobres não terão a chance de crescer antes de ficarem "verdes", n. 703, p. 52-54, 27 jun. 2012.

CASTRO, M. C. D. et al. Malaria risk on the Amazon frontier. Proceedings of the National Academy of Sciences, v. 103, n. 7, p. 2452-2457, 14 fev. 2006.

CASTRO, S. M. et al. Ecorregião Xingu-Tapajós - Principais vetores do desmatamento no município em Alta Floresta, MTIV UFRJ Ambientável. In: IV UFRJ AMBIENTÁVEL. Rio de Janeiro: Escola Politácnica da UFRJ, a 23 de Outubro de 2008 CELENTANO, D.; VERÍSSIMO, A. O avanço da fronteira na Amazônia: do boom ao colapso. Belém, PA: IMAZON, Instituto do Homem e Meio Ambiente da Amazônia, 2007. CHAMBERS, R. The origins and practice of participatory rural appraisal. World Development, v. 22, n. 7, p. 953-969, jul. 1994.

CHARRON, D. Ecohealth: Origins and approach. In: CHARRON, D. (Ed.). Ecohealth research in rractice: Innovative applications of an Ecosystem Approach to Health. New York: Springer Publishers, 2012. p. 1-33.

COMISSÃO MUNDIAL SOBRE O MEIO AMBIENTE E DESENVOLVIMENTO. Nosso futuro comum - Relatório Brundtland. Rio de Janeiro: FGV, 1988.

CONFALONIERI, U. E. C. Saúde na Amazônia: um modelo conceitual para a análise de paisagens e doenças. Estudos Avançados, v. 19, n. 53, p. 221-236, abr. 2005.

CONFERÊNCIA DAS NAÇÕES UNIDAS SOBRE MEIO AMBIENTE E DESENVOLVIMENTO. Agenda 21 Global. Brasília: Senado Federal/SSET, 1996.

CORBI, J. J. et al. Diagnóstico ambiental de metais e organoclorados em córregos adjacentes a áreas de cultivo de cana-de-açúcar (Estado de São Paulo, Brasil). Química Nova, v. 29, n. 1, p. 61-65, fev. 2006.

CORDIER, S. et al. Neurodevelopmental investigations among methylmercury-exposed children in French Guiana. Environmental Research, v. 89, n. 1, p. 1-11, maio 2002.

CORVALÁN, C. F.; KJELLSTRÖM, T.; SMITH, K. R. Health, environment and sustainable development: identifying links and indicators to promote action. Epidemiology (Cambridge, Mass.), v. 10, n. 5, p. 656-660, set. 1999. 
COX, C. Herbicide factsheet: Picloram. Journal of Pesticide Reform, v. 18, n. 1, p. 13-20, 1998.

COX, C. Herbicide factsheet: Glyphosate. Journal of Pesticide Reform, v. 24, n. 4, p. 1015, 2004.

COY, M. Différenctiation et transformation de l'espace ao Nord du Mato Grosso. Contribuition à un modèle dynamique des fronts pionniers en Amazonie brésilienne. In: ALBALADEJO, C.; TULET, J.-C. (Eds.). Les fronts pionniers de l'Amazonie brésilienne: la formation de nouveaux territoires. Paris: L'Harmattan, 1996. p. 103-27.

CPT, C. P. DA T. - R. M. G. Dossiê Imprensa e Documentos 1979/2. Cuiabá: CPT, 1979. CRESPO-LÓPEZ, M. E. et al. Mercury and neurotoxicity. Revista De Neurologia, v. 40, n. 7, p. 441-447, 1 abr. 2005.

CUNHA, J. M. P. D. Dinâmica migratória e o processo de ocupação do Centro-Oeste brasileiro: o caso de Mato Grosso. Rev. bras. estud. popul, v. 23, n. 1, p. 87-107, 2006.

CURVO, R. M.; PIGNATI, W. A.; PIGNATTI, M. G. Morbimortalidade por câncer infantojuvenil associada ao uso agrícola de agrotóxicos no Estado de Mato Grosso, Brasil. Cadernos Saúde Coletiva, v. 21, n. 1, p. 10-17, mar. 2013.

CZERESNIA, D. Constituição epidêmica: velho e novo nas teorias e práticas da epidemiologia. História, Ciências, Saúde-Manguinhos, v. 8, n. 2, p. 341-356, ago. 2001.

DALLA VILLA, R. et al. Dissipation of DDT in a heavily contaminated soil in Mato Grosso, Brazil. Chemosphere, v. 64, n. 4, p. 549-554, jul. 2006.

D'AMATO, C.; TORRES, J. P. M.; MALM, O. DDT (dicloro difenil tricloroetano): toxicidade e contaminação ambiental - uma revisão. Química Nova, v. 25, n. 6a, p. 995-1002, nov. 2002.

D'AMATO, C.; TORRES, J. P. M.; MALM, O. Determinação de ¿DDT encontradas em peixes comestíveis de diferentes áreas da Amazônia brasileira. Oecologia Brasiliensis, v. 11, n. 2, p. 202-212, 2007.

DEBOURDEAU, A. Les grands textes fondateurs de l'écologie. [Paris]: Flammarion, 2013.

DE CASTRO, M. C.; SAWYER, D. O.; SINGER, B. H. Spatial patterns of malaria in the Amazon: Implications for surveillance and targeted interventions. Health \& Place, v. 13, n. 2, p. 368-380, jun. 2007.

DE LAU, L. M. L.; BRETELER, M. M. B. Epidemiology of Parkinson's disease. Lancet Neurology, v. 5, n. 6, p. 525-535, jun. 2006.

DE OLIVEIRA, B. F. A. DE; IGNOTTI, E.; HACON, S. A systematic review of the physical and chemical characteristics of pollutants from biomass burning and combustion of fossil 
fuels and health effects in Brazil. Cad. Saúde Pública [online], v. 27, n. 9, p. 1678-1698, 2011.

DE OLIVEIRA SANTOS, E. et al. Mercury Exposure in Munduruku Indians from the Community of Sai Cinza, State of Pará, Brazil. Environmental Research, v. 90, n. 2, p. 98103, out. 2002.

DOCKERY, D. W. Epidemiologic evidence of cardiovascular effects of particulate air pollution. Environmental Health Perspectives, v. 109 Suppl 4, p. 483-486, ago. 2001.

DOLBEC, J. et al. Methylmercury exposure affects motor performance of a riverine population of the Tapajós river, Brazilian Amazon. International archives of occupational and environmental health, v. 73, n. 3, p. 195-203, abr. 2000.

DOMINGUES, M. S.; BERMANN, C. O arco de desflorestamento na Amazônia: da pecuária à soja. Ambiente \& sociedade, v. 15, n. 2, p. 1-22, ago. 2012.

DROULERS, M.; LE TOURNEAU, F.-M. Amazonie: la fin d'une frontière? Caravelle, Cahiers du Monde hispanique et luso-brésilien, v. 75, p. 109-135, 2000.

DROULERS, M.; LE TOURNEAU, F.-M. La question environnementale vue du sud, vue du nord : l'exemple de l'Amazonie brésilienne. Revue socialiste, v. 27, p. 15-31, 2007.

DUARTE, E. C. et al. The changing distribution of malaria in the Brazilian Amazon, 20032004 and 2008-2009. Revista da Sociedade Brasileira de Medicina Tropical, v. 47, n. 6, p. 763-769, 2014.

DUARTE, L. C. B. A política ambiental internacional: Uma introdução. Cena Internacional, v. 6 , n. 1, p. 4-12, 2004.

DUBREUIL, V. Etude des relations entre les caractéristiques géographiques de la surface et les nuages convectifs dans la région de l'arc de déforestation en Amazonie. Tese de Doutorado-Marseille: Université d'Aix-Marseille, 2002.

DUBREUIL, V. Climats et pionniers du Mato Grosso : apport des données satellitaires et de la modélisation pour le suivi des interactions nature/société dans une région de front pionnier de l'Amazonie brésilienne. Dossier pour l'habilitation à diriger des recherches-Rennes: Université Rennes 2, 2005.

DUBREUIL, V. et al. Etude de l'impact du changement de l'occupation du sol sur les températures dans la région d'Alta Floresta, Brésil. Bulletin de la Société géographique de Liège, v. 51, p. 79-90, 2008.

DUCHIADE, M. P. Poluição do ar e doenças respiratórias: uma revisão. Cad. Saúde Públ., v. 8, n. 3, p. 311-330, 1992.

EWART, E. Panará: a volta dos índios gigantes. Revista de Antropologia, v. 41, n. 1, p. 255-261, 1998. 
FARIA, A. A. C.; FERREIRA NETO, P. S. Ferramentas de diálogo: qualificando o uso das técnicas de DRP - diagnóstico rural participativo. Brasília: Ministério do Meio Ambiente; Instituto Internacional de Educação do Brasil, 2006.

FARIA, N. M. X. et al. Farm work, dust exposure and respiratory symptoms among farmers. Revista de saúde pública, v. 40, n. 5, p. 827-836, out. 2006.

FARIAS, M. R. DE C. DE et al. Prevalência de asma em escolares de Alta Floresta município ao sudeste da Amazônia brasileira. Revista Brasileira de Epidemiologia, v. 13, n. 1, p. 49-57, mar. 2010.

FÁVERO, K. A. S. Pulverizações de agrotóxicos nas lavouras em Lucas do Rio Verde MT e os agravos respiratórios em crianças menores de 5 anos de idade no período de 2004 a 2009. Dissertação de Mestrado em Saúde Coletiva-Cuiabá: Universidade Federal de Mato Grosso, 2011.

FEARNSIDE, P. M. Desmatamento na Amazônia brasileira: história, índices e conseqüências. Megadiversidade, v. 1, n. 1, p. 113-123, 2005.

FEOLA, G.; BAZZANI (EDS.). Desafíos y Estrategias para la Implementación de un Enfoque Ecossistémico para la Salud Humana en los Países en Desarollo: reflexiones a propósito de las consultas regionales. Montevideo: CIID, 2002.

FERRAZ, H. B. et al. Rural or urban living and Parkinson's disease. Arquivos de NeuroPsiquiatria, v. 54, n. 1, p. 37-41, mar. 1996.

FERREIRA, J. C. V.; MOURA E SILVA, J. Mato Grosso e seus municípios. Cuiabá: Editora Memória Brasileira, 2008.

FILLION, M. et al. Neurotoxic sequelae of mercury exposure: an intervention and follow-up study in the Brazilian Amazon. EcoHealth, v. 8, n. 2, p. 210-222, jun. 2011.

FINKELMAN, J.; FRANCO NETTO, G.; GALVÃO, L. A. C. Prefácio. In: MINAYO, M. C. S.; MIRANDA, A. C. DE (Eds.). Saúde e ambiente sustentável: estreitando nós. Rio de Janeiro: FIOCRUZ, 2002. p. 11-14.

FISCHER, G.-N.; DODELER, V. Psychologie de la santé et environnement facteurs de risque et prévention. Paris: Dunod, 2009.

FLEMING, L. et al. Parkinson's disease and brain levels of organochlorine pesticides. Annals of Neurology, v. 36, n. 1, p. 100-103, jul. 1994.

FLORES, A. V. et al. Organoclorados: um problema de saúde pública. Ambiente \& sociedade, v. 7, n. 2, dez. 2004.

FORGET, G.; LEBEL, J. An ecosystem approach to human health. International journal of occupational and environmental health, v. 7, n. 2 Suppl, p. S3-38, jun. 2001.

FOUCHER, M. La mise en valeur de l'Amazonie brésilienne. Problèmes d'Amérique Latine, v. 33, p. 71-94, 1974. 
FRANCO, J. L. DE A. et al. História ambiental: fronteiras, recursos naturais e conservação da natureza. Rio de Janeiro: Garamond, 2012.

FREITAS, C. M. DE et al. Ecosystem approaches and health in Latin America. Cadernos de Saúde Pública, v. 23, n. 2, p. 283-296, fev. 2007.

FREITAS, C. M. DE; PORTO, M. F. Saúde, ambiente e sustentabilidade. Rio de Janeiro: Ed. Fiocruz, 2006.

GIDDENS, A. As conseqüências da modernidade. São Paulo: UNESP, 1991.

GIDDENS, A. A vida em uma sociedade pós-tradicional. In: BECK, Ü.; GIDDENS, A.; LASH, S. (Eds.). . Modernização reflexiva. São Paulo: UNESP, 1997. p. 73-134.

GIL, A. C. Métodos e técnicas de pesquisa social. São Paulo: Atlas, 2008.

GOLDBLATT, D. Teoria social e ambiente. Lisboa: Instituto Piaget, 1996.

GOMES, M. J. M. Ambiente e pulmão. J Pneumol, v. 28, n. 5, p. 261-269, 2002.

GONÇALVES, C. Avaliação de Projetos - Fundo Amazônia - Projeto "Sementes do Portal". In: MARCOVITCH, J. (Ed.). Fundo Amazônia: Cooperação Internacional e Gestão Brasileira. São Paulo: USP, 2014. v. 1p. 80-96.

GONÇALVES, C. W. P. O desafio ambiental. Rio de Janeiro: Editora Record, 2004.

GONÇALVES, K. DOS S.; CASTRO, H. A. DE; HACON, S. DE S. As queimadas na região amazônica e o adoecimento respiratório. Ciência \& Saúde Coletiva, v. 17, n. 6, p. 15231532, jun. 2012.

GOUVERNEMENT FRANÇAIS. Décret n 2012-665 du 4 mai 2012 révisant et complétant les tableaux des maladies professionnelles en agriculture annexés au livre VII du code rural et de la pêche maritime. Ministère de l'Agriculture, de l'Agroalimentaire et de la Forêt, mai 2012.

GRANDJEAN, P. et al. Methylmercury neurotoxicity in Amazonian children downstream from gold mining. Environmental Health Perspectives, v. 107, n. 7, p. 587-591, jul. 1999.

GRISOLIA, C. K. Agrotóxicos: mutações, reprodução \& câncer. Brasília: UnB, 2005.

GUIMARÃES, J. Origins and effects of mercury on riparian populations of the Brazilian Amazon. Int J Occup Environ Health, n. 7, p. 23-25, 2001.

GUIMARÃES, J. R. D.; MERGLER, D. A virtuous cycle in the Amazon: Reducing mercury exposure from fish consumption requires sustainable agriculture. In: CHARRON, D. F. (Ed.). Ecohealth research in practice. Ottawa: International Development Research Centre, 2011. p. 119-32.

GUIMARÃES NETO, R. B. A lenda do ouro verde: política de colonização no Brasil contemporâneo. Cuiabá, MT : [Brasília, Brazil]: UNICEN Publicações; UNESCO, 2002.

GUIMARÃES NETO, R. B. Vira mundo, vira mundo: trajetórias nômades. As cidades na Amazônia - Mato Grosso. Revista de Pós Graduação da PUC, v. 27, p. 49-69, 2003. 
HACON, S. et al. Atmospheric Mercury and Trace Elements in the Region of Alta Floresta in the Amazon Basin. In: PORCELLA, D. B.; HUCKABEE, J. W.; WHEATLEY, B. (Eds.). . Mercury as a Global Pollutant. Dordrecht: Springer Netherlands, 1995. p. 273-283.

HACON, S. et al. Risk assessment of mercury in Alta Floresta. Amazon Basin - Brazil. In: WHEATLEY, B.; WYZGA, R.; MCCORMAC, B. M. (Eds.). Mercury as a Global Pollutant: Human Health Issues. Dordrecht: Springer Netherlands, 1997a. p. 91-105.

HACON, S. et al. Mercury exposure through fish consumption in the urban area of Alta Floresta in the Amazon Basin. Journal of Geochemical Exploration, v. 58, n. 2-3, p. 209216, abr. 1997b.

HACON, S. Exposure to Mercury in Pregnant Women from Alta Floresta-Amazon Basin, Brazil. Environmental Research, v. 84, n. 3, p. 204-210, nov. 2000.

HACON, S. et al. Evaluación de riesgo una herramienta para el proceso de gerenciamiento socioambiental: estudio de caso región Norte de Mato Grosso. In: SILVA, C. R. et al. (Eds.). Geologia médica no Brasil: efeitos dos materiais e fatores geológicos na saúde humana e meio ambiente. Workshop Internacional de Geologia Médica. Rio de Janeiro: Serviço Geológico do Brasil, 2006. p. 48-54.

HANNIGAN, J. A. Sociologia ambiental: A formação de uma perspectiva social. Lisboa: Instituto Piaget, 1995.

HOGAN, D. J. et al. Um breve perfil ambiental da região Centro-Oeste. Campinas: Ed. UNICAMP, 2000.

HOMMA, A. K. O. Amazônia pós-código florestal e pós-Rio+20, novos desafios. Revista de Economia e Agronegócio, v. 10, n. 2, p. 206-240, 2012.

HORLICK-JONES, T.; SIME, J. Living on the border: knowledge, risk and transdisciplinarity. Futures, v. 36, n. 4, p. 441-456, maio 2004.

HTTP:/MWW.SOCIOAMBIENTAL.ORG. Fiscalização aumenta presença na Amazônia, mas impunidade para os crimes ambientais continua. Disponível em: <http://siteantigo.socioambiental.org/esp/desmatamento/site/fiscalizacao_controle/fiscalizacao_aument a_impunidade_continua>. Acesso em: 18 jul. 2014.

IBGE. Censo Agropecuário 2006.2 Disponível em: <http://www.sidra.ibge.gov.br/bda/pesquisas/ca/default.asp?o=2\&i=P\#13>. Acesso em: 23 jul. 2014.

IBGE. Indicadores de Desenvolvimento Sustentável - Edição 2013. Disponível em: $<$ http://www.sidra.ibge.gov.br/bda/pesquisas/ids/default.asp?o=8\&i=P>.

IBGE. Cidades@. Disponível em: <www.cidades.ibge.gov.br/>.

IBGE, I. B. DE G. E E. SIDRA - Banco de dados agregados. Disponível em: <http://www.sidra.ibge.gov.br/bda/tabela/protabl.asp?c=73\&z=p\&o=26\&i=P>. 
IGNOTTI, E. et al. Efeitos das queimadas na Amazônia: método de seleção dos municípios segundo indicadores de saúde. Revista Brasileira de Epidemiologia, v. 10, n. 4, dez. 2007.

IGNOTTI, E. et al. Impact on human health of particulate matter emitted from burnings in the Brazilian Amazon region. Revista de Saúde Pública, v. 44, n. 1, p. 121-130, fev. 2010a.

IGNOTTI, E. et al. Air pollution and hospital admissions for respiratory diseases in the subequatorial Amazon: a time series approach. Cad Saude Publica, v. 26, n. 4, p. 747-761, abr. 2010b.

INPE. Desflorestamento nos Municípios da Amazônia Legal para o ano de 2012. Disponível em: <http://www.dpi.inpe.br/prodesdigital/atrmunic.php?ID=5100250\&ano=2012\&>. INPE. SIG Queimadas. Disponível em: <http://www.dpi.inpe.br/proarco/bdqueimadas/>. ISHITANI, L. $H$. et al. Desigualdade social e mortalidade precoce por doenças cardiovasculares no Brasil. Revista de Saúde Pública, v. 40, n. 4, p. 684-691, ago. 2006. JACOBSON, L. DA S. V. et al. Association between fine particulate matter and the peak expiratory flow of schoolchildren in the Brazilian subequatorial Amazon: A panel study. Environmental Research, v. 117, p. 27-35, ago. 2012.

JATENE, H. DA S. Reabertura da fronteira sobre controle: a colonização particular dirigida de Alta Floresta. Dissertação de Mestrado em Sociologia-Campinas: Universidade Estadual de Campinas, 1983.

JEPSON, W. Private agricultural colonization on a Brazilian frontier, 1970-1980. Journal of Historical Geography, v. 32, n. 4, p. 839-863, out. 2006.

JOANONI NETO, V. Fronteiras da crença: ocupação do norte de Mato Grosso após 1970. Cuiaba, MT́: EdUFMT : Carlini \& Caniato Editorial, 2007.

JOBIM, P. F. C. et al. Existe uma associação entre mortalidade por câncer e uso de agrotóxicos?: Uma contribuição ao debate. Ciência \& Saúde Coletiva, v. 15, n. 1, p. 277288, jan. 2010.

KAMEL, F.; HOPPIN, J. A. Association of Pesticide Exposure with Neurologic Dysfunction and Disease. Environmental Health Perspectives, v. 112, n. 9, p. 950-958, 20 maio 2004. KATSURAGAWA, T. H. et al. Endemias e epidemias na Amazônia: malária e doenças emergentes em áreas ribeirinhas do Rio Madeira. Um caso de escola. Estudos Avançados, v. 22, n. 64, p. 111-141, dez. 2008.

KAY, J. K. et al. An ecosystem approach for sustainability: addressing the challenge of complexity. Futures, v. 31, n. 7, p. 721-742, 1999.

KRUEGER, R. A. Focus group: a pratical guide for applied research. Newbury Park: Sage Publications, 1988. 
LACERDA, L. D. Contaminação por mercúrio no Brasil: fontes industriais vs garimpo de ouro. Química Nova, v. 20, n. 2, p. 196-199, abr. 1997.

LACERDA, L. D.; DE SOUZA, M.; RIBEIRO, M. G. The effects of land use change on mercury distribution in soils of Alta Floresta, Southern Amazon. Environmental Pollution (Barking, Essex: 1987), v. 129, n. 2, p. 247-255, maio 2004.

LACERDA, L. D.; MALM, O. Contaminação por mercúrio em ecossistemas aquáticos: uma análise das áreas críticas. Estudos Avançados, v. 22, n. 63, p. 163-190, 2008.

LAPLANTINE, F. Antropologia da doença. São Paulo: Martins Fontes, 1991.

LAPLANTINE, F. Antropologia dos sistemas de representações da doença: sobre algumas pesquisas desenvolvidas na França contemporânea reexaminadas à luz de uma experiência brasileira. In: JODELET, D. (Ed.). As representações sociais. Rio de Janeiro: EdUERJ, 2001. p. 241-259.

LATOUR, B. Jamais fomos modernos: ensaio de antropologia simétrica. Rio de Janeiro: Editora 34, 2005.

LAURELL, A. C. La salud-enfermedad como proceso social. Rev Panam Salud, v. 2, p. 725, 1982.

LEBEL, J. et al. Neurotoxic effects of low-level methylmercury contamination in the Amazonian Basin. Environmental research, v. 79, n. 1, p. 20-32, out. 1998.

LEBEL, J. Health: an ecosystem approach. Ottawa: International Development Research Centre, 2003.

LE BORGNE-DAVID, A. Les migrations paysannes du sud-Brésil vers L'Amazonie: Le salariat plutôt que la malaria. Paris: Editions L'harmattan, 1998.

LEFF, E. Epistemologia ambiental. São Paulo: Ed. Cortez, 2001.

LÉNA, P. Expansion de la frontière économique, accès au marché et transformation de l'espace rural en Amazonie brésilienne. Cahiers des Sciences Humaines, v. 28, n. 4, p. 579-601, 1992

LENFANT, C. Can we prevent cardiovascular diseases in low- and middle-income countries? Bulletin of the World Health Organization, v. 79, n. 10, p. 980-982; discussion 983-987, 2001.

LERVOLINO, S. A.; PELICIONI, M. C. F. A utilização do grupo focal como metodologia qualitativa na promoção da saúde. Revista da Escola de Enfermagem da USP, v. 35, n. 2, p. 115-121, jun. 2001.

LESSA, I. Doenças crônicas não-transmissíveis no Brasil: um desafio para a complexa tarefa da vigilância. Ciência \& Saúde Coletiva, v. 9, n. 4, p. 931-943, dez. 2004.

LESSA, R. Amazônia: as raízes da destruição. São Paulo: Atual, 1991. 
LEWIN, K. Group decision and social change. In: MACCOBY, E. E.; NEWCOMB, T. M.; HARTLEY, E. L. (Eds.). Readings in social psychology. New York: Holt, Rinehart, Winston, 1958. p. 197-211.

LIMA, G. F. Análise parasitológica em alface (Lactuca sativa) de três hortas do município de Alta Floresta - MT. Trabalho de Conclusão de Curso-Alta Floresta: Universidade do Estado de Mato Grosso, 2011.

LIN, N.; GARRY, V. F. In vitro studies of cellular and molecular developmental toxicity of adjuvants, herbicides, and fungicides commonly used in Red River Valley, Minnesota. Journal of Toxicology and Environmental Health. Part A, v. 60, n. 6, p. 423-439, 28 jul. 2000.

LOIOLA, C. C. P.; MANGABEIRA DA SILVA, C. J.; TAUIL, P. L. Controle da malária no Brasil: 1965-2001. Rev Panam Salud Publica, v. 11, p. 235-44, 2002.

LOUREIRO, V. R. Amazônia: uma história de perdas e danos, um futuro a (re)construir. Estudos Avançados, v. 16, n. 45, p. 107-121, ago. 2002.

MAENHAUT, W. et al. Two-year study of atmospheric aerosols in Alta Floresta, Brazil: Multielemental composition and source apportionment. Nuclear Instruments and Methods in Physics Research Section B: Beam Interactions with Materials and Atoms, v. 189, n. 1-4, p. 243-248, abr. 2002.

MALM, O. Gold mining as a source of mercury exposure in the Brazilian Amazon. Environmental research, v. 77, n. 2, p. 73-78, maio 1998.

MARC, J.; MULNER-LORILLON, O.; BELLÉ, R. Glyphosate-based pesticides affect cell cycle regulation. Biology of the Cell, v. 96, n. 3, p. 245-249, abr. 2004.

MARTINS, E. N. Análise parasitológica em alface (Lactuca sativa) de três hortas convencionais do município de Carlinda - MT. Trabalho de Conclusão de Curso-Alta Floresta: Universidade do Estado de Mato Grosso, 2008.

MARTINS, J. DE S. O tempo da fronteira. Retorno à controvérsia sobre o tempo histórico da frente de expansão e da frente pioneira. Tempo Social; Rev. Sociol. USP, v. 8, n. 1, p. 2770, 1996.

MARTINS, J. DE S. Fronteira: a degradação do outro nos confins do humano. São Paulo: Hucitec, 1997.

MATO GROSSO. Informações em saúde - SES-MT, 2014. Disponível em: <http://appweb3.saude.mt.gov.br/informacao-saude/pesquisa-municipal>

MDIC. Balança Comercial Brasileira por Município. Disponível em: <http://www.desenvolvimento.gov.br//sitio/sistema/balanca/>. 
MEDEIROS, M. S. DE et al. Custo das doenças atribuíveis a fatores ambientais na cidade de Manaus, Amazonas, Brasil. Ciência \& Saúde Coletiva, v. 19, n. 2, p. 599-608, fev. 2014.

MELLO, N. A. Contradições territoriais: signos do modelo aplicado na Amazônia. Soc. estado, v. 18, n. 1-2, p. 339-360, 2013.

MENDONÇA, F. La question environnementale en géographie au Brésil: une approche épistémologique. Norois, n. 197, p. 55-67, 1 dez. 2005.

MERTENS, F. et al. Network Approach for Analyzing and Promoting Equity in Participatory Ecohealth Research. EcoHealth, v. 2, n. 2, p. 113-126, 15 abr. 2005.

MERTENS, F.; SAINT-CHARLES, J.; MERGLER, D. Social communication network analysis of the role of participatory research in the adoption of new fish consumption behaviors.

Social Science \& Medicine (1982), v. 75, n. 4, p. 643-650, ago. 2012.

MERTON, R.; KENDALL, P. Das fokussierte interview. In: HOPF, C.; WEINGARTEN, E. (Eds.). Qualitative sozialforschung. 2. ed. Stuttgart: Klett-Cotta, 1984. p. 171-204.

MILLS, N. L. et al. Adverse cardiovascular effects of air pollution. Nature Clinical Practice Cardiovascular Medicine, v. 6, n. 1, p. 36-44, jan. 2009.

MINAYO-GOMEZ, C.; MINAYO, M. C. S. Enfoque ecossistêmico de saúde: Uma estratégia transdisciplinar. InterfacEHS, v. 1, n. 1, p. 1-19, 2006.

MINAYO, M. C. DE S. et al. Pesquisa social: Teoria, método e criatividade. 23. ed. Petrópolis: Vozes, 2004.

MINAYO, M. C. DE S. Contribuições da antropologia para pensar a saúde. In: CAMPOS, G. W. DE S. et al. (Eds.). Tratado de saúde coletiva. 2. ed. São Paulo: Hucitec, 2006. p. 189218.

MINAYO, M. C. S.; CARVALHO, A. M. Saúde e ambiente sustentável: estreitando nós. Rio de Janeiro: FIOCRUZ, 2002.

MIRANDA, M. O papel da colonização dirigida na expansão da fronteira agrícola na Amazônia. In: BECKER, B. K.; MIRANDA, M.; MACHADO, L. O. (Eds.). Fronteira amazônica: questões sobre a gestão do território. Brasília: Ed. UnB, 1990. p. 47-62.

MONDARDO, M. L.; GOETTERT, J. D. Frente de expansão e frente pioneira no Brasil: Espaços e tempos da migração, do conflito e da alteridade. Revista OKARA: Geografia em debate, v. 2, p. 38-61, 2007.

MOREIRA, I. S. Gouvernance territoriale du développement rural au Brésil. Le cas d'un front pionnier: "Portal da Amazônia". Thèse de Doctorat en Géographie et Aménagement-Toulouse: Université Toulouse II, 2014.

MOREIRA, J. C. et al. Avaliação do risco à saúde humana decorrente do uso de agrotóxicos na agricultura e pecuária na região Centro-Oeste. Brasília: CNPq, 2010. 
MOREIRA, J. C. et al. Contaminação de águas superficiais e de chuva por agrotóxicos em uma região de Mato Grosso. Cien Saude Colet, v. 17, n. 6, p. 1557-1568, 2012.

MORENO, G. O processo histórico de acesso à terra em Mato Grosso. Geosul, v. 14, n. 27, p. 67-90, 1999.

MOSCOVICI, S. Social representations: explorations in social psychology. Cambridge, England: Polity Press, 2000.

MOSTAFALOU, S.; ABDOLLAHI, M. Pesticides and human chronic diseases: Evidences, mechanisms, and perspectives. Toxicology and Applied Pharmacology, v. 268, n. 2, p. 157-177, abr. 2013.

MOURA, D. G. Mídia e corrupção: a Operação Curupira na Amazônia. Dissertação de Mestrado em Desenvolvimento Sustentável—Brasília: Universidade de Brasília, 2006.

MOURA, M. et al. Qualidade do ar e transtornos respiratórios agudos em crianças. Revista de Saúde Pública, v. 42, n. 3, p. 503-511, jun. 2008.

MUELLER, C. C. Dinâmica, condicionantes e impactos socioambientais da evolução da fronteira agrícola no Brasil. Rev. Adm. púb., v. 26, n. 3, p. 64-87, 1992.

NASCIMENTO, L. F. C.; MEDEIROS, A. P. P. DE. Admissions due to pneumonia and biomass burning: a spatial approach. Jornal de Pediatria, 20 mar. 2012.

NEPSTAD, D. et al. Road paving, fire regime feedbacks, and the future of Amazon forests. Forest Ecology and Management, v. 154, n. 3, p. 395-407, dez. 2001.

NEPSTAD, D. C.; ALMEIDA, O. T. A Amazônia no caminho da transição agrícola mundial. É possível usar as forças do mercado para reduzir os impactos ecológicos e sociais negativos da expansão da agropecuária industrial?. Belém: IPAM/WHRC, 2005.

NEPSTAD, D. C.; MOREIRA, A.; ALENCAR, A. A. A floresta em chamas: Origens, impactos e prevenção de fogo na Amazônia. Brasília: IPAM, 1999.

NESPOLI, A. et al. Perfil socioeconômico dos horticultores do município de Alta Floresta/MTCadernos de Agroecologia. In: RESUMOS DO VIII CONGRESSO BRASILEIRO DE AGROECOLOGIA. Porto Alegre: Associação Brasileira de Agroecologia - ABAAgroecologia, 2003

NEVES, D. P. Parasitologia Dinâmica. 2. ed. São Paulo: Atheneu, 2006.

NICOLIS, G.; PRIGOGINE, I. Self-organization in non-equilibrium systems. New York: Wiley-Interscience, 1977.

NICOLIS, G.; PRIGOGINE, I. Exploring complexity. New York: W. H. Freeman, 1989.

NIELSEN, N. O. Ecosystem approaches to human health. Cad. Saúde Pública, v. 17, n. suppl., p. S69-S75, 2001. 
NOYCE, A. J. et al. Meta-analysis of early nonmotor features and risk factors for Parkinson disease. Annals of Neurology, v. 72, n. 6, p. 893-901, dez. 2012.

NUNES, K. V. L.; NEVES, S. M. A. S.; IGNOTTI, E. Mortality due to diseases of the circulatory system among the elderly population in Brazilian Amazon: temporal and spatial analysis. Rev. bras. epidemiol, v. 16, n. 4, p. 838-48, 2013.

NUNES, K. V. R.; IGNOTTI, E.; HACON, S. DE S. Circulatory disease mortality rates in the elderly and exposure to PM2.5 generated by biomass burning in the Brazilian Amazon in 2005. Cadernos de Saúde Pública, v. 29, n. 3, p. 589-598, mar. 2013.

OLIVEIRA-FERREIRA, J. et al. Malaria in Brazil: an overview. Malaria Journal, v. 9, n. 1, p. 115, 2010.

OLIVEIRA FILHO, J. P. DE. O Caboclo e o Brabo: notas sobre duas modalidades de força de trabalho na expansão da fronteira amazônica no século XIX. Rio de Janeiro: Civilização Brasileira, 1979. v. 11

OLSON, S. H. et al. Deforestation and Malaria in Mâncio Lima County, Brazil. Emerging Infectious Diseases, v. 16, n. 7, p. 1108-1115, jul. 2010.

ONU. Declaração de Estocolmo sobre o ambiente humano. Estocolmo: Conferência das Nações Unidas sobre Meio Ambiente Humano, 1972.

OPAS. Determinantes ambientais e sociais da saúde. Organização Pan-Americana da Saúde, Escritório Regional para as Américas da Organização Mundial da Saúde; Editora Fiocruz, 2011.

OPAS, S. S. A. 2. Enfoques ecossistêmicos em saúde - Perspectivas para sua adoção no Brasil e em países da América Latina. Organização Pan-Americana da Saúde - OPAS / Ministério da Saúde., 2009.

PÁDUA, G. L. D. DE. A epistemologia genética de Jean Piaget. Revista FACEVV, v. 2, p. 22-35, 2009.

PÁDUA, J. A. As bases teóricas da história ambiental. Estudos Avançados, v. 24, n. 68, p. 81-101, 2010.

PALMA, D. C. DE A. Agrotóxicos em leite humano de mães residentes em Lucas do Rio Verde - MT. Dissertação de Mestrado em Saúde Coletiva-Cuiabá: Universidade Federal de Mato Grosso, 2011.

PARKES, M. W. et al. All Hands on Deck: Transdisciplinary Approaches to Emerging Infectious Disease. EcoHealth, v. 2, n. 4, p. 258-272, 10 nov. 2005.

PEREIRA FILHO, S. R. Metais pesados nas sub-bacias hidrográficas de Poconé e Alta Floresta. Rio de Janeiro: CETEM/CNPq, 1995. 
PEREIRA, V. S. et al. Análise dos atendimentos ambulatoriais por doenças respiratórias no Município de Alta Floresta - Mato Grosso - Amazônia brasileira. Epidemiologia e Serviços de Saúde, v. 20, n. 3, p. 393-400, set. 2011.

PIAGET, J. A equilibração das estruturas cognitivas: problema central do desenvolvimento. Rio de Janeiro: Zahar, 1976.

PIGNATI, W. A.; MACHADO, J. M. H.; CABRAL, J. F. Acidente rural ampliado: o caso das "chuvas" de agrotóxicos sobre a cidade de Lucas do Rio Verde - MT. Ciênc. saúde coletiva, v. 12, n. 1, p. 105-114, mar. 2007.

PIKETTY, M.-G. et al. Determinantes da expansão da pecuária na Amazônia oriental: conseqüências para as políticas públicas. Cadernos de Ciência \& Tecnologia, v. 22, n. 1, p. 221-234, 2005.

PNUD. Índice de Desenvolvimento Humano no Brasil 2013: Perfil do município de Alta Floresta - MT. Disponível em: <http://www.atlasbrasil.org.br/2013>.

POCCARD-CHAPUIS, R. Les réseaux de la conquête. Rôle des filières bovines dans la structuration de l'espace sur les fronts pionniers d'Amazonie Orientale brésilienne. Thèse de doctorat en géographie-Paris: Université Paris X - Nanterre, 2004.

PORTO, M. F. DE S. Uma ecologia política dos riscos: Princípios para integrarmos o local e o global na promoção da saúde e da justiça ambiental. Rio de Janeiro: Fiocruz, 2007.

PRETI, O. Expectativas educacionais numa área de fronteira agrícola (a escola vista pelos colonos de Alta Floresta). Dissertação de Mestrado em Educação-São Carlos: Universidade Federal de São Carlos, 1981.

PROCÓPIO, S. O. et al. Fitorremediação de solo contaminado com picloram por capim-péde-galinha-gigante (Eleusine coracana). R. Bras. Ci. Solo, v. 32, p. 2517-2524, 2008.

PROJETO CARUSO. Degradação ambiental, mercúrio e saúde no Tapajós. Santarém: Université du Québec à Montréal (Canadá) / Universidade de Brasília, 2008.

RAPPORT, D. (ED.). Ecosystem health. Malden, MA: Blackwell Science, 1998.

REBORATTI, C. Migraciones y frontera agraria: Argentina y Brasil en la cuenca del Alto Paraná-Uruguay. Cuardernos del CENEP, v. 8, p. 47, 1979.

RIBEIRO, A. R.; SILVA, F. C. A Colonização promovida por empresas e famílias do CentroSul do Brasil no Estado do Mato-Grosso 1958-2008. Papers do NAEA N² 274, p. 1-22, 2010.

RIBEIRO, H. Queimadas de cana-de-açúcar no Brasil: efeitos à saúde respiratória. Revista de Saúde Pública, v. 42, n. 2, p. 370-376, abr. 2008.

RIBEIRO, H.; ASSUNÇÃO, J. V. DE. Efeitos das queimadas na saúde humana. Estudos Avançados, v. 16, n. 44, p. 125-148, abr. 2002. 
RIBEIRO, J. D. Terra e garimpos: um estudo da violência na consolidação do espaço da colonização Alta Floresta - MT (1978 - 1983). Dissertação de Mestrado em HistóriaCuiabá: Universidade Federal de Mato Grosso, 2001.

ROCHA, J. M. DE F. Alfabetização em Alta Floresta: aspectos de uma trajetória (19782006). Dissertação de Mestrado em Educação-Cuiabá: Universidade Federal de Mato Grosso, 2008.

ROULET, M. et al. Distribution and partition of total mercury in waters of the Tapajós River Basin, Brazilian Amazon. Science of The Total Environment, v. 213, n. 1-3, p. 203-211, jun. 1998.

ROULET, M. et al. Effects of recent human colonization on the presence of mercury in Amazonian ecosystems. Water, Air, and Soil Pollution, v. 112, n. 3-4, p. 297-313, 1999.

SABOURIN, E.; RODRIGUES, J. A. Interação entre políticas públicas e dinâmicas locais da agricultura familiar no território Portal da Amazônia. In: Desenvolvimento territorial: Diretrizes para a região da BR-163. Brasília: WWF-Brasil, 2010. v. 2.

SACHS, I. Sociedade, cultura e meio ambiente. Mundo \& Vida, v. 2, n. 1, p. 7-13, 2000.

SASSAKI, A. H. Projeto Olhos d'água da Amazônia - Alta Floresta (MT). In: MARCOVITCH, J. (Ed.). . Fundo Amazônia: Uma Experiência de Cooperação Internacional e Gestão Brasileira. São Paulo: USP, 2014. v. 1p. 33-42.

SAWYER, D. R. Fluxo e refluxo da fronteira agrícola no Brasil: ensaio de interpretação estrutural e espacial. Revista Brasileira de Estudos de População, v. 1, n. 1/2, p. 3-33, 1984.

SAWYER, D. R. The potential contribuition of social research to controlo of malaria in Brazil. Mem. Inst. Oswaldo Cruz, v. 81, n. Suppl II, p. 31-37, 1986.

SAWYER, D. R. Frontier malaria in the Amazon region of Brazil: types of malaria situations and some implications for control. PAHOMHO/TDR. Technical consultation on Research in support of malaria control in the Amazon., 1988.

SAWYER, D. R. Economic and social consequences of malaria in new colonization projects in Brazil. Soc.Sci. Med., v. 37, n. 9, p. 1131-I36, 1993.

SAYAGO, D.; TOURRAND, J.-F.; BURSZTYN, M. Introdução - um olhar sobre a Amazônia: das cenas aos cenários. In: SAYAGO, D.; TOURRAND, J. F.; BURSZTYN, M. (Eds.). . Amazônia: cenas e cenários. Brasília: Ed. UnB, 2004. p. 17-28.

SCHAEFER, J. R. As migrações rurais e implicações pastorais: Um estudo das migrações campo-campo do Sul do país em direção ao Norte de Mato Grosso. São Paulo: Edições Loyola, 1985.

SCHIESARI, L.; GRILLITSCH, B. Pesticides meet megadiversity in the expansion of biofuel crops. Frontiers in Ecology and the Environment, v. 9, n. 4, p. 215-221, maio 2011. 
SCHITTINI, G. DE M.; FRANCO, J. L. DE A.; DRUMMOND, J. A. Expansão da fronteira de recursos naturais e Unidades de Conservação da natureza na área da influência da BR-163. In: FRANCO, J. L. DE A.; DRUMMOND, J. A.; TAVARES, G. G. (Eds.). História ambiental: fronteiras, recursos naturais e conservação da natureza. Rio de Janeiro: Garamond, 2012. p. 119-146.

SCHMIDT, M. I. et al. Chronic non-communicable diseases in Brazil: burden and current challenges. The Lancet, v. 377, n. 9781, p. 1949-1961, jun. 2011.

SCHNEIDER, R. et al. Sustainable Amazon: limitations and opportunities for rural development. Washington D. C.: World Bank, 2000.

SCHWANTES, N. Uma cruz em Terra Nova. São Paulo: Scritta Oficina Editorial, 1989.

SCLIAR, M. História do conceito de saúde. Physis: Revista de Saúde Coletiva, v. 17, n. 1, p. 29-41, abr. 2007.

SELUCHINESK, R. D. R. De heróis a vilões: imagem e auto-imagem dos colonos da Amazônia mato-grossense. Tese de Doutorado em Desenvolvimento SustentávelBrasília: Universidade de Brasília, 2008.

SILVA, J. M. DA et al. Agrotóxico e trabalho: uma combinação perigosa para a saúde do trabalhador rural. Ciência \& Saúde Coletiva, v. 10, n. 4, p. 891-903, dez. 2005.

SILVA, D. M. Amazônia, a pátria dos mitos. In: $61^{\mathrm{a}}$ Reunião Anual da SBPC. Manaus: SBPC, 2009

SILVA, D. R. X. et al. Hanseníase, condições sociais e desmatamento na Amazônia brasileira. Revista Panamericana de Salud Pública, v. 27, n. 4, abr. 2010.

SILVA, J. R. R. et al. Agrotóxicos comercializados no município de Alta Floresta no triênio de 2006 a 2008. Revista de Ciências Agro-Ambientais, v. 9, n. 2, p. 283-299, 2011.

SINGER, B. H.; CASTRO, M. C. Agricultural colonization and malaria on the Amazon frontier. Annals of the New York Academy of Sciences, v. 954, p. 184-222, dez. 2001.

SOARES-FILHO, B. S. et al. Cenários de desmatamento para a Amazônia. Estudos Avançados, v. 19, n. 54, p. 137-152, ago. 2005.

SOUZA, S. C. Desmatamento e clima em Alta Floresta - Amazônia mato-grossense.

Dissertação de Mestre em Geografia-Cuiabá: Universidade Federal de Mato Grosso, 2006. STAHEL, A. W. Capitalismo e entropia: Os aspectos ideológicos de uma contradição e a busca de alternativas sustentáveis. In: CAVALCANTI, C. (Ed.). Desenvolvimento e natureza: Estudos para uma sociedade sustentável. [s.I.] Ed. Cortez, 1994. p. 104-27.

STOCKHOLM RESILIENCE CENTRE. Resilience dictionary. Disponível em: <http://www.stockholmresilience.org/21/research/what-is-resilience/resiliencedictionary.html>. Acesso em: 15 jul. 2014. 
STOKOLS, D. et al. Evaluating transdisciplinary science. Nicotine \& Tobacco Research: Official Journal of the Society for Research on Nicotine and Tobacco, v. 5 Suppl 1, p. S21-39, dez. 2003.

TANNER, C. M. et al. Rotenone, paraquat, and Parkinson's disease. Environmental Health Perspectives, v. 119, n. 6, p. 866-872, jun. 2011.

TCHOUNWOU, P. B. et al. Review: Environmental exposure to mercury and its toxicopathologic implications for public health. Environmental Toxicology, v. 18, n. 3, p. 149-175, 2003.

TEMPESTA, G. A. Travessia dos banzeiros. Historicidade e organização sociopolítica Apiaká. Tese de Doutorado em Antropologia Social-Brasília: Universidade de Brasília, 2009.

TEMPESTA, G. A. Guerreiros, riquezas e onças nas rotas fluviais. Notas históricas e etnográficas sobre os Apiaká. Revista Brasileira de Linguística Antropológica, v. 2, n. 1, p. 77-97, 2010a.

TEMPESTA, G. A. Vivendo como parente: notas sobre a concepção de pessoa e a organização social apiaká. Soc. e Cult., v. 13, n. 1, p. 91-99, $2010 b$.

THIOLLENT, M. Metodologia da pesquisa-ação. São Paulo: Cortez, 2005.

TOURRAND, J. F.; VALARIÉ, P.; OLIVEIRA, J. R. D. Monopoly amazonien. Cahiers Agricultures, v. 16, n. 5, p. 423-427, 2007.

TRAD, L. A. B. Grupos focais: conceitos, procedimentos e reflexões baseadas em experiências com o uso da técnica em pesquisas de saúde. Physis: Revista de Saúde Coletiva, v. 19, n. 3, 2009.

U.S. ENVIRONMENTAL PROTECTION AGENCY. Great Lakes. Disponível em: $<$ http://www.epa.gov/greatlakes/atlas/glat-ch5.html>.

VENITES, V. Processo de construção de um instrumento de avaliação das diretrizes da Estratégia Saúde da Família. Dissertação de Mestrado em Saúde Coletiva-Cuiabá: Universidade Federal de Mato Grosso, 2009.

VERAS, R. P.; ARAÚJO, A. (EDS.). Epidemiologia: contextos e pluralidade. Rio de Janeiro, RJ: Editora Fiocruz: ABRASCO, 1998.

VESTENA, C. L. B. Piaget e a questão ambiental: sujeito epistêmico, diagnóstico e considerações educacionais. São Paulo: Cultura Acadêmica, 2011.

VILLAS BÔAS, R. C. The mercury problem in the Amazon due to gold extraction. Journal of Geochemical Exploration, v. 58, n. 2-3, p. 217-222, abr. 1997.

VIRTANEN, J. K. et al. Mercury as a risk factor for cardiovascular diseases. The Journal of Nutritional Biochemistry, v. 18, n. 2, p. 75-85, fev. 2007. 
VITTOR, A. Y. et al. Linking deforestation to malaria in the Amazon: characterization of the breeding habitat of the principal malaria vector, Anopheles darlingi. The American Journal of Tropical Medicine and Hygiene, v. 81, n. 1, p. 5-12, jul. 2009.

WAICHMAN, A. V. Uma proposta de avaliação integrada de risco do uso de agrotóxicos no estado do Amazonas, Brasil. Acta Amazonica, v. 38, n. 1, p. 45-50, 2008.

WALTNER-TOEWS, D. An ecosystem approach to health and its applications to tropical and emerging diseases. Cadernos de saúde pública, v. 17 Suppl, p. 7-22; discussion 23-36, 2001.

WALTNER-TOEWS, D. et al. Adaptive Methodology for Ecosystem Sustainability and Health (AMESH): An Introduction. In: MIDGLEY, G.; OCHOA-ARIAS, A. (Eds.). Community Operational Research: Systems Thinking for Community Development. Boston: Kluwer Academic Publishers, 2004.

WALTNER-TOEWS, D. et al. Agro-urban Ecosystem Health Assessment in Kathmandu, Nepal: Epidemiology, Systems, Narratives. EcoHealth, v. 2, n. 2, p. 155-164, 22 abr. 2005. WALTNER-TOEWS, D.; FERNANDES, O.; BRICEÑO-LEÓN, R. Un enfoque ecosistémico para la salud y las enfermedades transmisibles. In: FEOLA, G.; BAZZANI, R. (Eds.). . Desafíos y estrategias para la implementación de um enfoque ecosistémico para la salud humana em los países em desarrollo. Montevideo: Centro Internacional de Investigaciones para el Desarrollo (CIID), 2002. p. 29-42.

WANIEZ, P. La mortalité des populations sur les fronts pionniers agricoles du Brésil. Territoire en mouvement, v. 4, p. 17-33, 2007.

WASSERMAN, J. C.; HACON, S. DE S.; WASSERMAN, M. A. Ciclo do Mercúrio no Meio Ambiente Amazônico. Revista Mundo e Vida, v. 2, p. 46-53, 2001.

WEIHS, M.; MERTENS, F. Os desafios da geração do conhecimento em saúde ambiental: uma perspectiva ecossistêmica. Ciênc. saúde coletiva, v. 18, n. 5, p. 1501-1510, maio 2013.

WELLER, W. Grupos de discussão na pesquisa com adolescentes e jovens: aportes teóricometodológicos e análise de uma experiência com o método. Educação e Pesquisa, v. 32, n. 2, p. 241-260, ago. 2006.

WHO. Air quality guidelines: global update 2005: particulate matter, ozone, nitrogen dioxide, and sulfur dioxide. Copenhagen, Denmark: World Health Organization, 2006a.

WHO. Neurological disorders: public health challenges. Geneva: World Health Organization, 2006b.

WHO. World health statistics 2014. Geneva: World Health Organization, 2014a.

WHO. Cancer. Disponível em: <http://www.who.int/cancer/en/>. 
WHO. WHO campaigns. Disponível em: <http://www.who.int/campaigns/malariaday/2014/en/>. Acesso em: 11 jul. 2014c.

WHO. Cardiovascular disease. Disponível em:

<http://www.who.int/cardiovascular_diseases/en/>. Acesso em: 11 jul. 2014d.

WWW.COPEL.COM/. COPEL - Hidrelétrica Colíder. Disponível em:

$<$ http://www.copel.com/uhecolider/>.

WWW.UHETELESPIRES.COM.BR/. Hidrelétrica Teles Pires - energia eficiente.

Disponível em: <http://www.uhetelespires.com.br/site/empreendimento/\#body>.

YASUOKA, J.; LEVINS, R. Impact of deforestation and agricultural development on anopheline ecology and malaria epidemiology. The American journal of tropical medicine and hygiene, v. 76, n. 3, p. 450-460, mar. 2007.

ZAHIR, F. et al. Low dose mercury toxicity and human health. Environmental Toxicology and Pharmacology, v. 20, n. 2, p. 351-360, set. 2005. 
ANEXOS 


\section{ANEXO I - ROTEIRO PARA AS ENTREVISTAS}

\section{Roteiro para as entrevistas}

1 - DADOS PESSOAIS
Identificação da família
(sobrenome)

Endereço Telefones

\begin{tabular}{|l|l|l|}
\hline Nome dos participantes & $\begin{array}{l}\text { Local de } \\
\text { nascimento }\end{array}$ & $\begin{array}{l}\text { Ano de } \\
\text { nascimento }\end{array}$ \\
\hline & & \\
\hline & & \\
\hline & & \\
\hline & & \\
\hline & & \\
\hline & & \\
\hline & & \\
\hline
\end{tabular}

2 - FORMAÇÃO EDUCACIONAL (do patriarca ou da matriarca)

( ) Não escolarizado ( ) Ensino fundamental incompleto ( ) Ensino fundamental completo

( ) Ensino Médio ( ) Ensino superior: Curso

( ) Pós-graduação: Curso

\section{3 - DADOS REFERENTES Á MIGRAÇÃO}

Ano da migração

Localidade de moradia anterior 


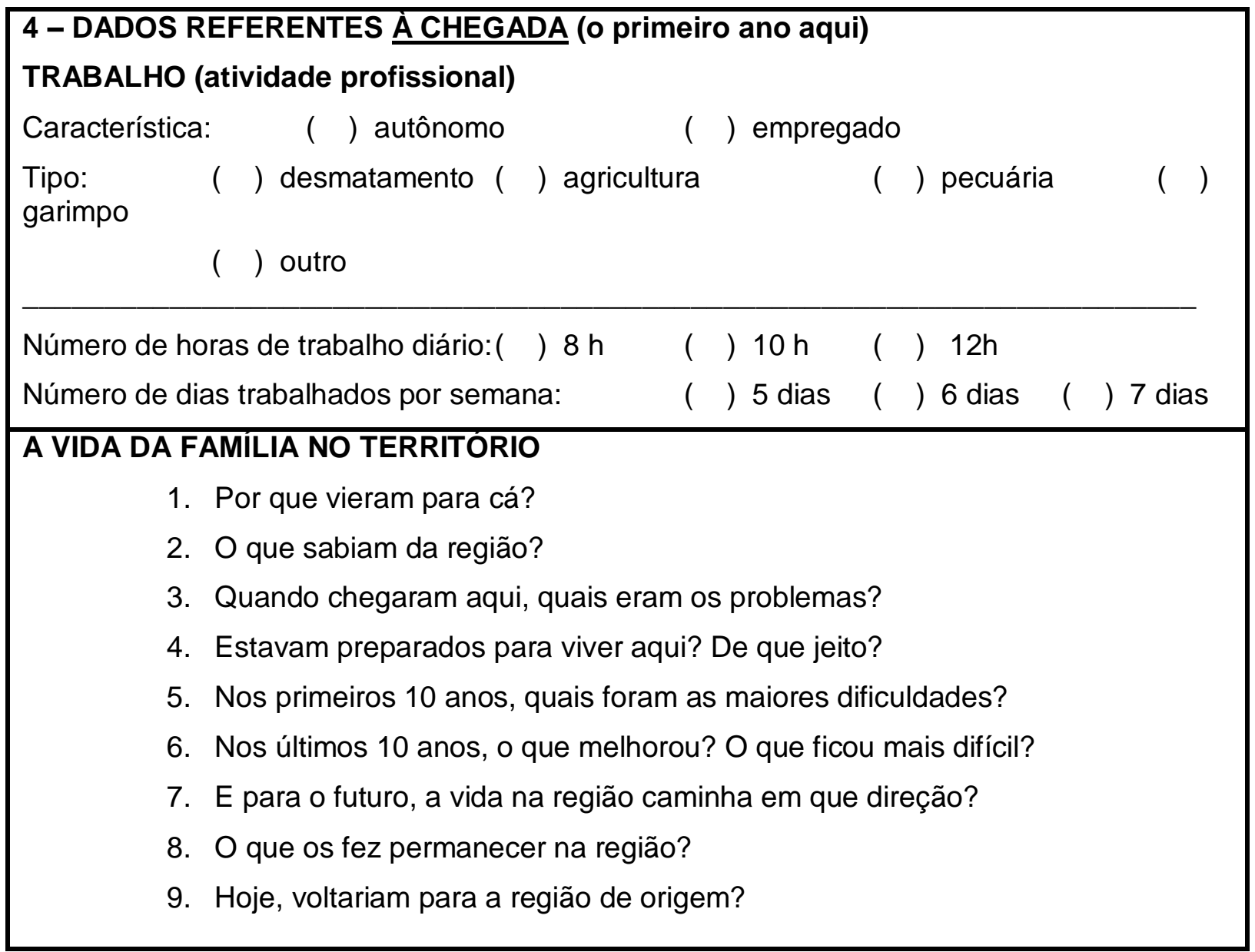




\section{ANEXO II - TERMO DE CONSENTIMENTO LIVRE E ESCLARECIDO}

\section{TERMO DE CONSENTIMENTO LIVRE E ESCLARECIDO}

\section{INFORMAÇÕES SOBRE A PESQUISA}

Título do projeto: AMBIENTE, SAÚDE E SUSTENTABILIDADE: DIMENSÕES DO DESENVOLVIMENTO DO TERRITÓRIO PORTAL DA AMAZÔNIA, MATO GROSSO, BRASIL

Responsável pela pesquisa: Marla Leci Weihs

Endereço e telefone para contato: SQN 411, Bloco A, apto 301, Brasília-DF - (66) 92430600

Esta pesquisa tem por objetivo analisar os fatores que determinaram e condicionaram o adoecimento de colonizadores do território Portal da Amazônia e suas influências nas atuais condições sociais da população.

Eu, juntamente com meus familiares, estou de acordo em participar da pesquisa, entendendo que a participação significa responder perguntas realizadas pelo entrevistador, permitindo sua gravação. Estou ciente que as informações anotadas serão tratadas confidencialmente, sendo que nem eu, nem minha família, seremos identificados durante a análise das informações da pesquisa.

Local e data:

Nome e assinatura do participante:

Nome e assinatura do responsável pela pesquisa:

Idade:

Formação:

Local de origem:

Ano em que ingressou no Sistema de Saúde:

Atividade/Setor: 


\section{ANEXO III - SÍNTESE DOS RESULTADOS}

\section{Grupo focal - Secretaria Municipal de Saúde de Alta Floresta}

\begin{tabular}{|c|c|c|}
\hline $\begin{array}{l}\text { Fases do } \\
\text { ciclo }\end{array}$ & $\begin{array}{l}\text { Agricultura e garimpo } \\
(1976-1992)\end{array}$ & $\begin{array}{l}\text { Madeira e pecuária } \\
\text { (1992 - }\end{array}$ \\
\hline \multirow[t]{10}{*}{$\begin{array}{l}\text { Principais } \\
\text { doenças }\end{array}$} & $\begin{array}{l}\text { Pium, mosquitos e leishmaniose. } \\
\text { Era necessário cobrir o corpo inteiro. Muitas } \\
\text { famílias voltaram para o Paraná por não } \\
\text { suportarem os ataques dos piuns. }\end{array}$ & $\begin{array}{l}\text { Doenças respiratórias, problema } \\
\text { de coluna, acidentes de } \\
\text { madeireira, acidentes de } \\
\text { motosserra. }\end{array}$ \\
\hline & Vacinação contra febre amarela. & Malária e leishmaniose \\
\hline & $\begin{array}{l}\text { A igreja católica, preocupada com a alta } \\
\text { prevalência de malária, leishmaniose, } \\
\text { tuberculose e hanseníase, montou equipes que } \\
\text { se formaram para trabalhar com bioenergético } \\
\text { (araminho). Informante da SUCAM. Fazia-se a } \\
\text { conciliação entre o bioenergético e o } \\
\text { diagnóstico por lâminas. Os próprios casais } \\
\text { faziam as coletas de sangue. }\end{array}$ & $\begin{array}{l}\text { A migração para a área urbana } \\
\text { também diminui a malária. }\end{array}$ \\
\hline & $\begin{array}{l}\text { Queda de barreira, afogamento, homicídios, } \\
\text { violência (causas externas) }\end{array}$ & \\
\hline & DSTs, drogas e álcool (lícitas e ilícitas) & \\
\hline & Blastomicose (PBmicose) & $\begin{array}{l}\text { Hipertensão, devido ao calor. Um } \\
\text { numero acima do normal num } \\
\text { bairro (Panorama = pobre), mais } \\
\text { de } 15 \% \text { da população são } \\
\text { hipertensos, inclusive entre jovens } \\
\text { entre } 8 \text { e } 15 \text { anos. Causas: } \\
\text { Problemas renais e alimentação } \\
\text { errada. }\end{array}$ \\
\hline & Alto índice de verminose e de doenças de pele. & \\
\hline & $\begin{array}{l}\text { "Porque o garimpeiro, ele não tem limites, ele } \\
\text { se sente mal, ele fica ali, mal e mal, e } \\
\text { contamina todo mundo e não vem tomar } \\
\text { medicação e aí, quando ele vem, ele toma um } \\
\text { dia do medicamento e volta e não dá } \\
\text { sequencia. Ele não se alimenta bem, então às } \\
\text { vezes ele tem intolerância à medicação porque } \\
\text { ele não se alimenta bem. E com isso, a malária } \\
\text { cresce rápido. Diferente dos que vieram } \\
\text { colonizar e que, quando se sentiam mal, } \\
\text { corriam para buscar o tratamento e seguir o } \\
\text { tratamento. A vida do garimpeiro é desregrada. } \\
\text { Ele se afunda lá no mato e ele só vai vir } \\
\text { quando der para vir, quando ele tirou o ouro } \\
\text { dele, que ele se satisfez, que ele vem". Nos } \\
\text { garimpos, ele trabalha praticamente sem roupa } \\
\text { e dentro da água. Ele dorme em uma rede, } \\
\text { está completamente exposto. }\end{array}$ & $\begin{array}{l}\text { Até a restrição do BHC se } \\
\text { acreditava só seria possível } \\
\text { controlar a doença com a } \\
\text { pulverização. A população cobrava } \\
\text { a borrifação do veneno. }\end{array}$ \\
\hline & $\begin{array}{l}\text { Havia pessoas imunes. A malária era } \\
\text { assintomática. Em 1999, um levantamento } \\
\text { mostrou que existiam muitas pessoas na região } \\
\text { que eram imunes. Elas era apenas portador e, } \\
\text { portanto, transmissor. }\end{array}$ & \\
\hline & $\begin{array}{l}\text { Sobre a distribuição da malária. Todos } \\
\text { pegavam a doença. O piloto do garimpo }\end{array}$ & \\
\hline
\end{tabular}




\begin{tabular}{|c|c|c|}
\hline & $\begin{array}{l}\text { pegava a doença tanto quanto ao garimpeiro. A } \\
\text { diferença esteve na origem das pessoas. } \\
\text { Algumas pessoas estavam mais preparadas } \\
\text { para buscar assistência médica. Era uma } \\
\text { questão cultural. }\end{array}$ & \\
\hline & $\begin{array}{l}\text { Correntão: era colocada uma corrente na } \\
\text { estrada. O pessoal que vinha do garimpo era } \\
\text { barrado, era feira a lamina e na volta a pessoa } \\
\text { recebia o resultado e tomar o remédio. Eles } \\
\text { vinham para cidade para festar e } \\
\text { esparramavam a doença na cidade. }\end{array}$ & \\
\hline & $\begin{array}{l}\text { Outro trabalho de controle: parceria entre o } \\
\text { coordenador da malária e o secretario da } \\
\text { saúde treinaram pessoas das comunidades } \\
\text { rurais para trabalharem como voluntários para } \\
\text { a borrifação das casas. }\end{array}$ & \\
\hline \multirow[t]{8}{*}{$\begin{array}{l}\text { Sistema de } \\
\text { saúde }\end{array}$} & $\begin{array}{l}\text { Formação de enfermeiras bastante básica. O } \\
\text { diagnóstico e o atendimento ficavam } \\
\text { prejudicados }\end{array}$ & 1997 - começa a chegar o SUS. \\
\hline & $\begin{array}{l}\text { Hospital Alliança (hospital da colonizadora, que } \\
\text { cobria as despesas). Gomes e enfermeiros. } \\
\text { Hospital Divina Providência (Gomes). Hospital } \\
\text { cristo redentor - hospitais privados. Quem tinha } \\
\text { apoio da colonizadora ou dinheiro tinha acesso } \\
\text { à saúde. }\end{array}$ & $\begin{array}{l}\text { Prefeitos: Edson constrói o } \\
\text { esqueleto do hospital municipal. } \\
\text { Elói põe em funcionamento. }\end{array}$ \\
\hline & 1983 - Posto de saúde Ana Neri (INAMPs). & Agentes comunitários de saúde. \\
\hline & $\begin{array}{l}\text { Prefeitura entra no processo (construção do } \\
\text { hospital municipal). }\end{array}$ & $\begin{array}{l}\text { Primeiro PSF: Vila Nova (1998). } \\
\text { Segundo: Panorama. } \\
\text { Projeto beija-flor (médico da } \\
\text { família, vacina, acompanhamento } \\
\text { de uma equipe) }\end{array}$ \\
\hline & Sucam - & \\
\hline & $\begin{array}{l}\text { Indeco financiou a } 1^{\text {a }} \text { campanha de vacinação } \\
\text { de crianças. }\end{array}$ & $\begin{array}{l}\text { Entidades - Rotary e Lyons - } \\
\text { faziam vacinações, abraçavam o } \\
\text { trabalho de vacinação da indeco. }\end{array}$ \\
\hline & $\begin{array}{l}1988 \text { - formação de parteiras e agentes de } \\
\text { saúde }\end{array}$ & \\
\hline & $\begin{array}{l}\text { Médicos enriqueceram muito rápido e } \\
\text { perderam a sensibilidade social. }\end{array}$ & \\
\hline \multirow[t]{5}{*}{$\begin{array}{l}\text { Degradação } \\
\text { ambiental }\end{array}$} & $\begin{array}{l}\text { Muita fumaça e poeira. As crianças eram } \\
\text { dispensadas da escola, o avião não decolava } \\
\text { na pista. Provocava doenças respiratórias. }\end{array}$ & $\begin{array}{l}\text { Termina o garimpo, as pessoas } \\
\text { saem da mata, reduz a malária. }\end{array}$ \\
\hline & $\begin{array}{l}\text { Equívocos do governo federal: incentivos } \\
\text { (institucionalização) ao desmatamento. } \\
\text { Mudança posterior: conservação. }\end{array}$ & \\
\hline & $\begin{array}{l}\text { Não houve instruções quanto à preservação da } \\
\text { mata ciliar. }\end{array}$ & \\
\hline & $\begin{array}{l}\text { Os agricultores chegavam abriam uma clareira } \\
\text { e depois derrubavam o resto. Deixavam } \\
\text { alguma floresta aqueles que tinham alguma } \\
\text { sensibilidade. Os madeireiros iam até as } \\
\text { propriedades pra comprar a madeira, pagando } \\
\text { um valor irrisório. O agricultor prepara o solo } \\
\text { pra plantar. "Ninguém era bandido, ainda, tudo } \\
\text { certinho, tudo regularizado". }\end{array}$ & $\begin{array}{l}\text { Reforma agrária, com a } \\
\text { implantação de assentamentos. } \\
\text { Pressão do incra: na ausência de } \\
\text { desmatamento do assentado } \\
\text { poderia perder o terreno. }\end{array}$ \\
\hline & $\begin{array}{l}\text { "Nós éramos os bandeirantes do século XX } \\
\text { fazendo um bom trabalho. quando a Lei muda } \\
\text { e quem as questões ambientais, aí é que a }\end{array}$ & \\
\hline
\end{tabular}




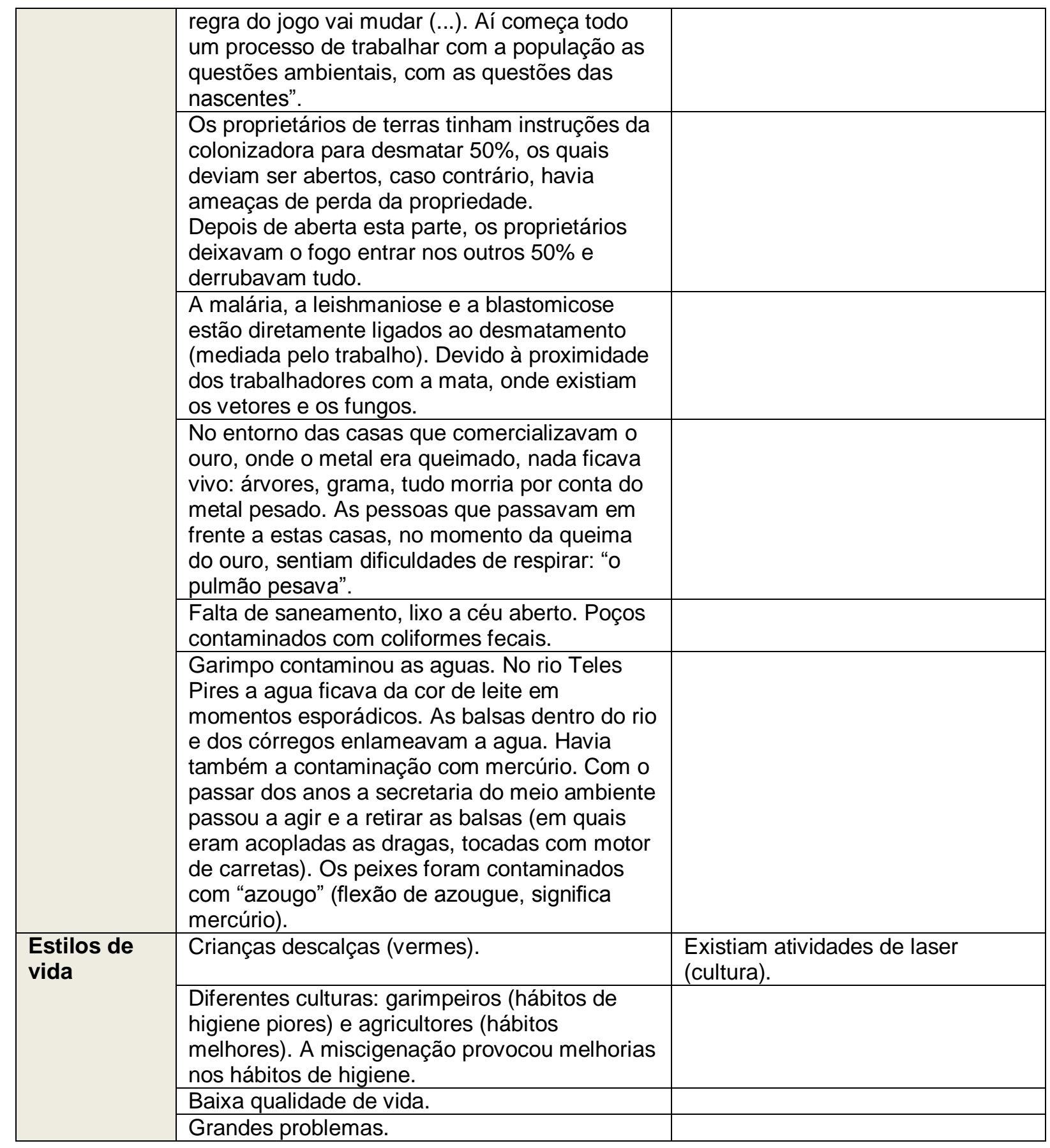

\begin{tabular}{|l|l|l|}
\hline $\begin{array}{l}\text { Fases do } \\
\text { ciclo }\end{array}$ & $\begin{array}{l}\text { Fiscalização e pecuária } \\
\mathbf{( 2 0 0 0} \text { - controle) } \\
\text { (2005 - com operações) }\end{array}$ & $\begin{array}{l}\text { Hidrelétrica, pecuária e soja e arroz (produção } \\
\text { mecanizada) } \\
\text { (2010 - }\end{array}$ \\
\hline $\begin{array}{l}\text { Principais } \\
\text { doenças }\end{array}$ & $\begin{array}{l}\text { Avanço da pecuária, } \\
\text { desaparece a malária }\end{array}$ & $\begin{array}{l}\text { Risco de reaparecimento da malária, dengue e } \\
\text { DST/HIV/hepatite }\end{array}$ \\
\cline { 2 - 3 } & $\begin{array}{l}\text { Doenças respiratórias e } \\
\text { crônico-degenerativas } \\
\text { (hipertensão, diabetes, } \\
\text { cardíacas) }\end{array}$ & $\begin{array}{l}\text { Tendência de queda da hanseníase (todo mundo já } \\
\text { teve!). devido ao maior conhecimento (prevenção) } \\
\text { da doença. }\end{array}$ \\
\cline { 2 - 3 } & $\begin{array}{l}\text { Dengue (doença que depende } \\
\text { dos cidadãos) e } \\
\text { DST/HIV/hepatite (maior }\end{array}$ & Hepatite e câncer. \\
& \\
\hline
\end{tabular}




\begin{tabular}{|c|c|c|}
\hline & $\begin{array}{l}\text { possibilidade de diagnóstico, } \\
\text { antes disto não era percebida). }\end{array}$ & \\
\hline & $\begin{array}{l}\text { Hanseníase: Alta capacidade } \\
\text { de detenção. Doença que } \\
\text { depende do sistema de saúde. }\end{array}$ & $\begin{array}{l}\text { Hoje o setor saúde é mais forte, no caso da } \\
\text { reemergência da malária, a atuação será imediata. } \\
\text { Não há mais risco de uma nova epidemia, mesmo } \\
\text { que exista uma nova febre de garimpo e pela } \\
\text { migração provocada pelas hidrelétricas. }\end{array}$ \\
\hline & $\begin{array}{l}\text { Doença de Jorge Lobo (micose } \\
\text { crônica) }\end{array}$ & \\
\hline & $\begin{array}{l}\text { Aumenta muito o numero de } \\
\text { casos de câncer. Causa } \\
\text { principal: mercúrio. }\end{array}$ & \\
\hline & $\begin{array}{l}\text { Depressão, principalmente } \\
\text { entre jovens (diagnóstico fácil, } \\
\text { os médicos confundem) }\end{array}$ & Transtorno mental (depressão e outras). \\
\hline & Transtorno mental & \\
\hline \multirow[t]{10}{*}{$\begin{array}{l}\text { Sistema de } \\
\text { saúde }\end{array}$} & $\begin{array}{l}\text { Escritórios regionais aumenta } \\
\text { o controle }\end{array}$ & $\begin{array}{l}\text { O numero de PSFs muda bastante o quadro da } \\
\text { saúde pública. }\end{array}$ \\
\hline & & Melhoria da qualidade de vida \\
\hline & & $\begin{array}{l}\text { Sistema de informação, diagnóstico, aumento da } \\
\text { cobertura da equipe da saúde da família, } \\
\text { estadualização do hospital, comunicação e } \\
\text { transporte - avanços decorrentes da entrada do } \\
\text { SUS. }\end{array}$ \\
\hline & & $\begin{array}{l}\text { O avanço poderia ser melhor se houvesse uma } \\
\text { dedicação maior da classe médica. }\end{array}$ \\
\hline & & $\begin{array}{l}\text { Implantação do UPA (Unidade de Pronto } \\
\text { Atendimento). }\end{array}$ \\
\hline & & $\begin{array}{l}\text { Parcerias com a hidrelétrica (investimento em } \\
\text { infraestrutura: PSFs). Problemas com a aplicação } \\
\text { do recurso financeiro. } \\
\text { Tendência (escolha da hidrelétrica): investimento } \\
\text { na formação dos profissionais de saúde. }\end{array}$ \\
\hline & & $\begin{array}{l}\text { A atividade do sistema de saúde depende da } \\
\text { sensibilidade do prefeito em relação à promoção da } \\
\text { saúde. Acontece em alguns casos. O problema } \\
\text { também está relacionado à formação médica (falta } \\
\text { sensibilidade para a promoção/ prevenção). }\end{array}$ \\
\hline & & $\begin{array}{l}\text { A demanda pela preparação dos postos de saúde } \\
\text { de profissionais médicos diante de um novo fluxo } \\
\text { populacional que vem devido às hidrelétricas e a } \\
\text { entrada do mercado da soja. }\end{array}$ \\
\hline & & $\begin{array}{l}\text { O principal problema é de infraestrutura em relação } \\
\text { à saúde }\end{array}$ \\
\hline & & $\begin{array}{l}\text { Problemas de segurança pública. A cadeia pública } \\
\text { foi feita para } 50 \text { pessoas e hoje tem } 170 \text { pessoas. } \\
\text { Ela se localiza no centro da cidade, dali pode sair } \\
\text { um foco de doenças. }\end{array}$ \\
\hline \multirow[t]{3}{*}{$\begin{array}{l}\text { Degradação } \\
\text { ambiental }\end{array}$} & $\begin{array}{l}\text { ONG: Amigos da terra e o ICV } \\
\text { - combate ao fogo. Ajudou a } \\
\text { reduzir as queimadas e, } \\
\text { consequentemente, as } \\
\text { doenças respiratórias. }\end{array}$ & $\begin{array}{l}\text { As reservas estão sendo preservadas e } \\
\text { recuperadas, o desmatamento caiu. "A realidade } \\
\text { caminha hoje para que nós tenhamos a meio e } \\
\text { longo prazo uma região sustentável". }\end{array}$ \\
\hline & & $\begin{array}{l}\text { Os madeireiros hoje estão plantando florestas } \\
\text { (teca). }\end{array}$ \\
\hline & & $\begin{array}{l}\text { Houve treinamento de agricultores, por parte da } \\
\text { secretaria municipal do meio ambiente. Formaram- } \\
\text { se pequenos grupos, aos quais foram ministradas }\end{array}$ \\
\hline
\end{tabular}




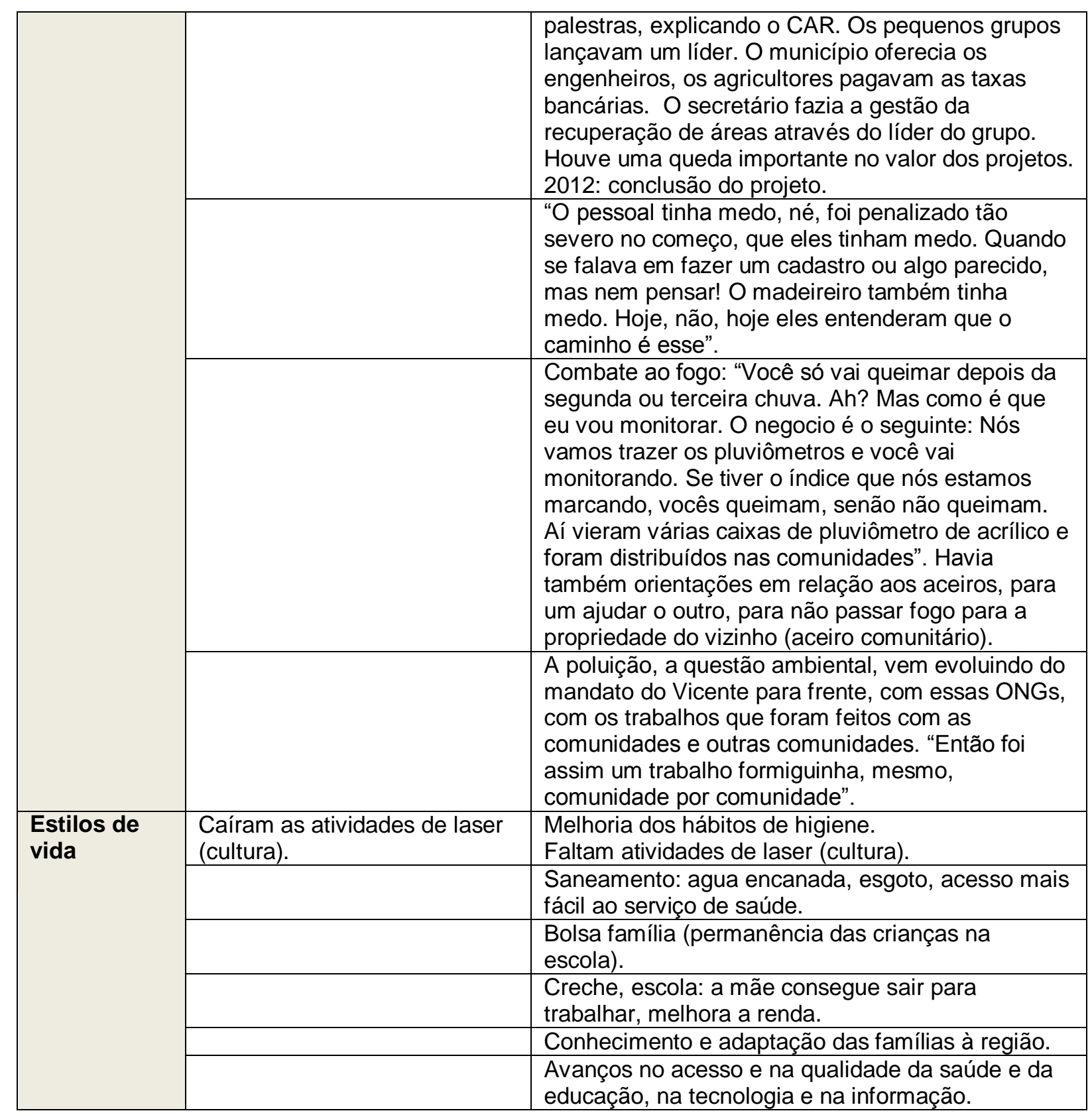

\section{Grupo focal - Escritório Regional de Alta Floresta}

\begin{tabular}{|l|l|l|}
\hline $\begin{array}{l}\text { Fases do } \\
\text { ciclo }\end{array}$ & $\begin{array}{l}\text { Agricultura e garimpo } \\
\mathbf{( 1 9 7 6 - 1 9 9 2 )}\end{array}$ & $\begin{array}{l}\text { Madeira e pecuária } \\
\text { (1992 - }\end{array}$ \\
\hline $\begin{array}{l}\text { Principais } \\
\text { doenças }\end{array}$ & $\begin{array}{l}\text { Morte por acidentes no trabalho de } \\
\text { desmatamento. Em apenas um ano morreram } \\
13 \text { pessoas (1976), principalmente por uso de } \\
\text { motosserra. Principalmente por queda de } \\
\text { arvores sobre os trabalhadores. } \\
\text { Mesmo com a mudança das formas de } \\
\text { trabalho, os acidentes continuaram existindo. }\end{array}$ & $\begin{array}{l}\text { A malária decai (a partir de 1992), } \\
\text { mas começam a aparecer os casos } \\
\text { urbanos da doença. }\end{array}$ \\
\cline { 2 - 3 } & $\begin{array}{l}\text { Até 1980 não existia malária na região. A } \\
\text { malária veio com os garimpeiros. Antes de 1980 } \\
\text { eram só causas externas (acidentes), com }\end{array}$ & $\begin{array}{l}\text { A concentração de trabalhadores } \\
\text { (densidade) era menor, o que } \\
\text { dificultava a circulação da malária. }\end{array}$ \\
\hline
\end{tabular}




\begin{tabular}{|c|c|}
\hline casos diários. & $\begin{array}{l}\text { Os trabalhadores também circulam } \\
\text { menos de região para região. }\end{array}$ \\
\hline $\begin{array}{l}\text { Garimpo, muito acidente de trabalho, por queda } \\
\text { de barreira. }\end{array}$ & $\begin{array}{l}\text { Com a redução da malária começa } \\
\text { a aparecer a leishmaniose } \\
\text { tegumentar, devido à proximidade } \\
\text { com a mata. O numero de casos } \\
\text { não foi elevado, mas ela se } \\
\text { mantem até os dias de hoje } \\
\text { (estabilizado). }\end{array}$ \\
\hline $\begin{array}{l}\text { Houve conflitos por invasão de terras da } \\
\text { colonizadora. }\end{array}$ & $\begin{array}{l}\text { Começam a aparecer as doenças } \\
\text { respiratórias. } 1999 \text { grandes } \\
\text { queimadas. }\end{array}$ \\
\hline $\begin{array}{l}\text { Malária e garimpo: de } 1987 \text { a } 1992 \text { foi a grande } \\
\text { epidemia. Coleta de } 100,200 \text { a } 300 \text { lâminas por } \\
\text { dia com uma positividade variando de } 30 \text { a } \\
40 \% \text {. } \\
1992 \text { foi o pico, fecharam o ano } 36 \text { mil } \\
\text { diagnósticos, } 55 \% \text { de positividade. } \\
1992 \text {, Paranaíta tinha } 11 \text { mil habitantes e deu } \\
12 \text { mil casos de malária. } \\
\text { Em 1993, o numero de laminas caiu para } 3 \text { a } 4 \\
\text { mil/ano. A queda se deve à extinção do } \\
\text { garimpo. }\end{array}$ & $\begin{array}{l}\text { Alto numero de casos de crianças } \\
\text { com sequelas cerebrais, } \\
\text { provavelmente relacionados ao uso } \\
\text { do mercúrio. }\end{array}$ \\
\hline $\begin{array}{l}\text { Os homens eram os mais afetados (tanto } \\
\text { agricultores como garimpeiros). Alguns morriam } \\
\text { entre a coleta de sangue e o resultado do } \\
\text { diagnostico. Os agricultores saiam do sitio, para } \\
\text { conseguir um recurso extra no garimpo e na } \\
\text { volta, contaminavam toda a família com a } \\
\text { malária. }\end{array}$ & \\
\hline $\begin{array}{l}\text { Todos adoeciam. Todos estavam expostos } \\
\text { devido à habitação, casa não protegida contra } \\
\text { mosquitos da malária. Não havia a cultura/ } \\
\text { conhecimento da malária para a prevenção. O } \\
\text { trabalho com a mata e com o brejo também foi } \\
\text { significativo. } \\
\text { As pessoas estavam expostas no horário do } \\
\text { banho, de ouvir o radio. O uso do mosquiteiro } \\
\text { não resolvia muito. }\end{array}$ & $\begin{array}{l}\text { Médicos consideram alta a } \\
\text { incidência de câncer (Dr. Webster) } \\
\text { e investigam na historia dos } \\
\text { pacientes a relação com o } \\
\text { mercúrio. }\end{array}$ \\
\hline Mercúrio: uso exacerbado. & \\
\hline $\begin{array}{l}\text { Agrotóxicos usados em orientação. O próprio } \\
\text { governo utilizava inseticidas sem nenhum } \\
\text { critério (quais serão os prejuízos? Não se } \\
\text { considerava). O objetivo era apenas eliminar o } \\
\text { mosquito. }\end{array}$ & \\
\hline $\begin{array}{l}\text { Hepatite e outras DSTs bastante comuns nesta } \\
\text { e em outras fases. }\end{array}$ & \\
\hline $\begin{array}{l}\text { Depressão relacionada a famílias de } \\
\text { garimpeiros, normalmente usuários de drogas e } \\
\text { abandono da mulher pelo trabalho e a } \\
\text { promiscuidade do homem no garimpo. }\end{array}$ & \\
\hline $\begin{array}{l}\text { Alcoolismo. Consumo muito alto nos garimpos, } \\
\text { inclusive entre os indígenas de regiões } \\
\text { adjacentes. }\end{array}$ & \\
\hline $\begin{array}{l}\text { Abortivo. Procura muito alta de mulheres por } \\
\text { remédios para o aborto. Elas utilizavam a } \\
\text { primaquina (antimalárico) como abortivo. }\end{array}$ & \\
\hline As doenças estão relacionadas ao & \\
\hline
\end{tabular}




\begin{tabular}{|c|c|c|}
\hline & $\begin{array}{l}\text { comportamento das pessoas diante de } \\
\text { determinadas situações de vida. }\end{array}$ & \\
\hline \multirow[t]{11}{*}{$\begin{array}{l}\text { Sistema de } \\
\text { saúde }\end{array}$} & $\begin{array}{l}\text { Não havia SUS, apenas hospitais privados e a } \\
\text { sucam (para diagnostico). As pessoas morriam } \\
\text { por falta de medicação. PDA (ponto de } \\
\text { distribuição de antimalárico). Distribuíam-se } \\
\text { medicamentos para uma pessoa que medicava } \\
\text { ou outros trabalhadores, sem exames prévios, } \\
\text { só com os sintomas. }\end{array}$ & Foco em outras doenças. \\
\hline & $\begin{array}{l}\text { Malária era combatida com inseticidas } \\
\text { (intervenção química) e o trabalho da sucam } \\
\text { (instalada em 1976). }\end{array}$ & $\begin{array}{l}\text { A partir de } 1996 \text { - instalação dos } \\
\text { serviços do SUS país afora. }\end{array}$ \\
\hline & Sucam vacinava contra a febre amarela. & CESP - hospital público. \\
\hline & $\begin{array}{l}\text { Todos os imóveis eram visitados, combatia-se } \\
\text { com isso a leishmaniose, febre amarela. }\end{array}$ & $\begin{array}{l}\text { 1987/88 - instalação do primeiro } \\
\text { hospital público (ainda com } \\
\text { caraterística de posto). Prefeito: } \\
\text { Edson Santos. }\end{array}$ \\
\hline & $\begin{array}{l}\text { A leishmaniose aparece quando o combate à } \\
\text { malária é desmobilizado. }\end{array}$ & $\begin{array}{l}\text { Prefeito: Robson Silva, ampliação } \\
\text { do posto e transformação em } \\
\text { hospital (de media complexidade). }\end{array}$ \\
\hline & $\begin{array}{l}\text { Atuação médica: não havia preocupação com o } \\
\text { comportamento, apenas tratamento de malária } \\
\text { e febre amarela. }\end{array}$ & $\begin{array}{l}\text { Final dos anos 1990: Nascimento } \\
\text { da atenção básica. }\end{array}$ \\
\hline & $\begin{array}{l}\text { A eficiência no tratamento da malária era uma } \\
\text { das melhores do país. Pacientes que saiam } \\
\text { para outros lugares se tratar, morriam. }\end{array}$ & \\
\hline & $\begin{array}{l}\text { A região era um laboratório de estudo da } \\
\text { malária. Com a vinda de equipes de } \\
\text { pesquisadores da Alemanha e outros países. }\end{array}$ & \\
\hline & $\begin{array}{l}\text { Especialistas em malária, localizados em } \\
\text { hospitais particulares. }\end{array}$ & \\
\hline & $\begin{array}{l}\text { Unidades de saúde (unidade de tratamento): } \\
\text { oferta de medicamentos. Tinha grande } \\
\text { quantidade de remédios (mais facilitado } \\
\text { naquela época). As pessoas eram internadas } \\
\text { em casas (os pobres). Ou eram tratados assim } \\
\text { ou morriam. } \\
\text { Os técnicos internavam doentes em suas } \\
\text { próprias casas. }\end{array}$ & \\
\hline & INAMPS: tratamento em Goiás. & \\
\hline $\begin{array}{l}\text { Degradação } \\
\text { ambiental }\end{array}$ & & $\begin{array}{l}\text { A derrubada era obrigatória. A } \\
\text { colonização fazia pressão: quem } \\
\text { não derrubasse perderia a terra. }\end{array}$ \\
\hline \multirow[t]{5}{*}{$\begin{array}{l}\text { Estilos de } \\
\text { vida }\end{array}$} & $\begin{array}{l}\text { Prostituição. Exposição ao sexo. A exposição } \\
\text { de homens é } 10 \times \text { maior do que de mulheres. } \\
\text { Ela é movida pelo mercado }(\$ \$) \text {. }\end{array}$ & $\begin{array}{l}\text { A educação em saúde surgiu com } \\
\text { a entrada dos agentes de saúde. }\end{array}$ \\
\hline & Falta de informações. & $\begin{array}{l}\text { Trabalhadores das madeireiras se } \\
\text { recusavam a usar EPIs (mudar } \\
\text { seus hábitos). }\end{array}$ \\
\hline & $\begin{array}{l}\text { A SUCAM informava que a os garimpeiros } \\
\text { estavam invadindo o espaço do garimpo e que } \\
\text { orientavam o uso de mosquiteiro, repelentes (o } \\
\text { que não adiantava muito). }\end{array}$ & \\
\hline & $\begin{array}{l}\text { A cultura era que a malária era transmitida pelo } \\
\text { cheiro do barro. }\end{array}$ & \\
\hline & $\begin{array}{l}\text { Diarreias e vômitos: no inicio e no final das } \\
\text { aguas. } \\
\text { A cinza das queimadas contaminava as aguas, }\end{array}$ & \\
\hline
\end{tabular}




\begin{tabular}{|l|l|l|}
\hline & dava problema de diarreia. & \\
\cline { 2 - 3 } & Não havia banheiros. & \\
\cline { 2 - 3 } & $\begin{array}{l}\text { Trabalhadores do sistema de saúde } \\
\text { trabalhavam sem EPls. }\end{array}$ & \\
\hline
\end{tabular}

\begin{tabular}{|c|c|c|}
\hline $\begin{array}{l}\text { Fases do } \\
\text { ciclo }\end{array}$ & $\begin{array}{l}\text { Fiscalização e pecuária } \\
\text { (2000 - controle) } \\
\text { (2005 - com operações) }\end{array}$ & $\begin{array}{l}\text { Hidrelétrica, pecuária e soja } \\
\text { (2010 - }\end{array}$ \\
\hline \multirow[t]{7}{*}{$\begin{array}{l}\text { Principais } \\
\text { doenças }\end{array}$} & $\begin{array}{l}\text { Aumento de internações e casos de óbito por } \\
\text { blastomicose (doenças respiratórias). }\end{array}$ & $\begin{array}{l}\text { Acidentes de trânsito, principalmente } \\
\text { envolvendo motociclistas. }\end{array}$ \\
\hline & $\begin{array}{l}\text { Quando diminui a fumaça aumenta a dengue } \\
\text { (depois de 2003). }\end{array}$ & $\begin{array}{l}\text { As pessoas demandam a aplicação } \\
\text { de veneno (fumasse) }\end{array}$ \\
\hline & $\begin{array}{l}\text { Casos anormais de gravidez anormais (a } \\
\text { partir de 2003), nas trompas e casos de } \\
\text { anencefalia. Médicos indicam ocorrências } \\
\text { atípicas na prevalência destes casos. Um } \\
\text { médico observou mais casos em Colíder que } \\
\text { o mesmo profissional encontrou em BH. Em } \\
\text { outro exemplo, um médico do RJ também } \\
\text { encontrou mais casos em Alta Floresta do } \\
\text { que no Rio. }\end{array}$ & $\begin{array}{l}\text { Aumento da prostituição e de DSTs. } \\
\text { Aumento de violências, assaltos, } \\
\text { assassinatos e estupros. }\end{array}$ \\
\hline & $\begin{array}{l}\text { Em 2001, indígenas morriam por diarreia } \\
\text { (alta prevalência). }\end{array}$ & $\begin{array}{l}\text { Hanseníase: município prioritário. O } \\
\text { numero de casos vem aumentando. } \\
\text { Doença degenerativa. Começa a } \\
\text { aparecer em crianças e jovens. }\end{array}$ \\
\hline & & $\begin{array}{l}\text { Tuberculose: casos de } \\
\text { multirresistência (não aumenta o } \\
\text { numero de casos) }\end{array}$ \\
\hline & & $\begin{array}{l}\text { As doenças do futuro dependem do } \\
\text { agronegócio. Produtos químicos } \\
\text { associados a degeneração } \\
\text { sanguínea. Se não houver controle } \\
\text { ode aumentar a incidência de câncer } \\
\text { e outras doenças degenerativas. }\end{array}$ \\
\hline & & $\begin{array}{l}\text { Aumento do uso de entorpecentes } \\
\text { (drogas), principalmente crack. }\end{array}$ \\
\hline \multirow[t]{4}{*}{$\begin{array}{l}\text { Sistema de } \\
\text { saúde }\end{array}$} & & $\begin{array}{l}\text { O acesso ao serviço de saúde é } \\
\text { maior que em outros centros. }\end{array}$ \\
\hline & & Foco forte no tratamento. \\
\hline & & $\begin{array}{l}13 \text { unidades do PSF, com } \\
\text { aproximadamente } 5 \text { médicos. Não é } \\
\text { adequado, deveria haver } 1 \text { medico } \\
\text { por PSF. O atendimento é familiar. } \\
\text { Há uma tendência de aprimoramento } \\
\text { dos serviços, com seleção dos } \\
\text { pacientes nos PSFs (atenção básica) } \\
\text { e posterior encaminhamento aos } \\
\text { hospitais (tratamento). }\end{array}$ \\
\hline & & $\begin{array}{l}\text { A presença do pronto socorro dentro } \\
\text { do hospital descaracteriza as suas } \\
\text { características. O hospital deveria } \\
\text { receber pacientes que viessem } \\
\text { apenas do sistema municipal (depois } \\
\text { dos PSFs e do pronto socorro) - } \\
\text { sistema básico. }\end{array}$ \\
\hline Degradação & Câncer: médicos suspeitam que existam & \\
\hline
\end{tabular}




\begin{tabular}{|l|l|l|}
\hline ambiental & $\begin{array}{l}\text { elementos naturais da Amazônia associados } \\
\text { à doença. Necessita de pesquisas. }\end{array}$ & \\
\cline { 2 - 3 } & $\begin{array}{l}\text { A fiscalização ambiental impacta na saúde } \\
\text { (queimadas). Diminui o risco. }\end{array}$ & $\begin{array}{l}\text { Falta educação para o sistema. O } \\
\text { usuário não sabe usar o sistema de } \\
\text { saúde (PSFs e hospitais). }\end{array}$ \\
\hline $\begin{array}{l}\text { Estilos de } \\
\text { vida }\end{array}$ & $\begin{array}{l}\text { Prostituição. Exposição ao sexo. (o } \\
\text { comportamento não mudou na era } \\
\text { da tecnologia). A exposição de } \\
\text { homens é 10 x maior do que de } \\
\text { mulheres. }\end{array}$ \\
\cline { 2 - 3 } & $\begin{array}{l}\text { O uso de EPIs em relação ao uso de } \\
\text { agrotóxicos também é difícil de ser } \\
\text { promovido. }\end{array}$ \\
\cline { 2 - 3 } & & \\
\hline
\end{tabular}

\section{Grupo focal - Secretaria Municipal de Saúde de Paranaíta}

\begin{tabular}{|c|c|c|}
\hline $\begin{array}{l}\text { Fases do } \\
\text { ciclo }\end{array}$ & Agricultura e garimpo & Madeira e pecuária \\
\hline \multirow[t]{5}{*}{$\begin{array}{l}\text { Principais } \\
\text { doenças }\end{array}$} & $\begin{array}{l}\text { Doenças enteroparasitárias (diarreias), } \\
\text { leishmaniose (endêmica), hepatite, } \\
\text { blastomicose (endêmica), DSTs. }\end{array}$ & $\begin{array}{l}\text { Leishmaniose, blastomicose, } \\
\text { hepatite, hanseníase, tuberculose, } \\
\text { doenças respiratórias (queimadas), } \\
\text { mortalidade infantil. }\end{array}$ \\
\hline & Malária & $\begin{array}{l}\text { Malária (até 1999). Fazia uma média } \\
\text { de } 200 \text { laminas por mês e dava até } \\
100 \text { positivas. }\end{array}$ \\
\hline & $\begin{array}{l}\text { Causas externas (assassinatos, } \\
\text { afogamentos por causa dos garimpos, } \\
\text { queda de barreira) }\end{array}$ & $\begin{array}{l}\text { Causas externas (morte por } \\
\text { acidentes nas madeireiras) e trator }\end{array}$ \\
\hline & $\begin{array}{l}\text { Acidentes com animais peçonhentos } \\
\text { (aranhas, escorpiões, serpentes, morcegos) }\end{array}$ & $\begin{array}{l}\text { Acidentes com animais peçonhentos } \\
\text { (aranhas, escorpiões, serpentes, } \\
\text { morcegos) }\end{array}$ \\
\hline & Abuso de álcool e de drogas & - \\
\hline \multirow[t]{4}{*}{$\begin{array}{l}\text { Sistema de } \\
\text { saúde }\end{array}$} & Sucam & $\begin{array}{l}\text { Informatização da saúde. } \\
\text { Estabelecimento de um sistema de } \\
\text { notificações. }\end{array}$ \\
\hline & $\begin{array}{l}\text { Predomínio do setor privado (hospitais e } \\
\text { laboratórios) }\end{array}$ & $\begin{array}{l}\text { Predomínio do setor privado } \\
\text { (hospitais e laboratórios) }\end{array}$ \\
\hline & Água tratada & Postos de saúde (2001) \\
\hline & Presença de benzedeiros. & $\begin{array}{l}\text { Início da qualificação dos } \\
\text { profissionais. }\end{array}$ \\
\hline $\begin{array}{l}\text { Degradação } \\
\text { ambiental }\end{array}$ & $\begin{array}{l}\text { Desmatamento e queimadas definem os } \\
\text { acidentes e as doenças respiratórias }\end{array}$ & $\begin{array}{l}\text { Queimadas, desmatamento, } \\
\text { poluição dos rios, azougue, dejetos, } \\
\text { assoreamento dos rios. }\end{array}$ \\
\hline \multirow[t]{2}{*}{$\begin{array}{l}\text { Estilos de } \\
\text { vida }\end{array}$} & $\begin{array}{l}\text { Falta de informação. Falta de acesso ao } \\
\text { sistema de saúde e à educação. Falta de } \\
\text { fiscalização. Falta de água tratada. Falta de } \\
\text { alimentação de qualidade. }\end{array}$ & Acesso aos industrializados \\
\hline & $\begin{array}{l}\text { Promiscuidade, violência, instalações } \\
\text { precárias, vida na mata, falta de segurança } \\
\text { pública, déficit de profissionais. }\end{array}$ & Aumento do acesso à informação \\
\hline
\end{tabular}




\begin{tabular}{|c|c|c|}
\hline $\begin{array}{l}\text { Fases do } \\
\text { ciclo }\end{array}$ & Fiscalização e pecuária & Hidrelétrica, pecuária \\
\hline \multirow[t]{5}{*}{$\begin{array}{l}\text { Principais } \\
\text { doenças }\end{array}$} & $\begin{array}{l}\text { Depressão (perda do emprego, } \\
\text { necessidade de ir embora) }\end{array}$ & Mortalidade de infantil quase zero. \\
\hline & $\begin{array}{l}\text { Doenças crônicas: câncer, diabetes, } \\
\text { doenças respiratórias (queimadas). } \\
\text { Das endemias só a malária que } \\
\text { acaba. }\end{array}$ & $\begin{array}{l}\text { Dengue, malária importada, doenças } \\
\text { respiratórias, blastomicose, DSTs, } \\
\text { hepatite, tuberculose importada, } \\
\text { hanseníase importada (associadas à } \\
\text { hidrelétrica). } \\
\text { Doenças pulmonares: casos graves } \\
\text { (crônicos). }\end{array}$ \\
\hline & $\begin{array}{l}\text { Câncer (desconfia-se do mercúrio - } \\
\text { contato com o vapor e alimentação } \\
\text { dos peixes e, também, pelo } \\
\text { envelhecimento da população). }\end{array}$ & Violência no trânsito. \\
\hline & $\begin{array}{l}\text { Acidentes com animais peçonhentos } \\
\text { (aranhas, escorpiões, serpentes, } \\
\text { morcegos) }\end{array}$ & $\begin{array}{l}\text { Acidentes com animais peçonhentos } \\
\text { (aranhas, escorpiões, serpentes, } \\
\text { morcegos) }\end{array}$ \\
\hline & - & Abuso de álcool e de drogas \\
\hline \multirow[t]{5}{*}{$\begin{array}{l}\text { Sistema de } \\
\text { saúde }\end{array}$} & $\begin{array}{l}\text { Melhoria das referencias para as } \\
\text { especialidades. Aumento da oferta de } \\
\text { especialidades. Aumento das } \\
\text { especialidades não médicas. }\end{array}$ & Informatização descentralizada da saúde \\
\hline & & $\begin{array}{l}\text { Fortalecimento das ações de vigilância, } \\
\text { promoção e prevenção da saúde. }\end{array}$ \\
\hline & & Fortalecimento da atenção básica. \\
\hline & & $\begin{array}{l}\text { Falha no suporte ao atendimento das } \\
\text { psicoses. }\end{array}$ \\
\hline & & $\begin{array}{l}\text { Saúde estruturada (menos impacto das } \\
\text { doenças). Melhorias estruturais e de } \\
\text { recursos humanos. }\end{array}$ \\
\hline $\begin{array}{l}\text { Degradação } \\
\text { ambiental }\end{array}$ & Catadores de lixo no lixão & Banalização da mídia \\
\hline \multirow{2}{*}{$\begin{array}{l}\text { Estilos de } \\
\text { vida }\end{array}$} & Aumento da escolaridade & Melhora do acesso á alimentação \\
\hline & Baixa qualidade de ensino & Pouca melhora nos hábitos de higiene. \\
\hline
\end{tabular}

\section{Grupo focal - Vila Nova}

\begin{tabular}{|c|c|c|}
\hline $\begin{array}{l}\text { Fases do } \\
\text { ciclo }\end{array}$ & Agricultura e garimpo & Madeira e pecuária \\
\hline \multirow{4}{*}{$\begin{array}{l}\text { Malária } \\
1979 / 80 \\
- \\
1992 / 93\end{array}$} & $\begin{array}{l}\text { As pessoas infectadas no garimpo traziam a doença para } \\
\text { a cidade. }\end{array}$ & $\begin{array}{l}\text { O fim do garimpo ajudou a } \\
\text { eliminar a malária. }\end{array}$ \\
\hline & $\begin{array}{l}\text { A malária teria acontecido mesmo sem a chegada do } \\
\text { garimpo. }\end{array}$ & $\begin{array}{l}\text { Começou a melhorar as } \\
\text { condições de higiene e } \\
\text { limpeza. As agentes de } \\
\text { saúde tem um papel } \\
\text { importante nisso. }\end{array}$ \\
\hline & A malária no garimpo era provocada pela áqua parada. & Ainda há poucos qarimpos. \\
\hline & $\begin{array}{l}\text { Na cidade, os mosquitos se multiplicavam nos poços. } \\
\text { A eliminação da malária na cidade decorre do uso de } \\
\text { fumacê, da redução dos poços e das privadas. }\end{array}$ & $\begin{array}{l}\text { O que eliminou a malária } \\
\text { foi o tratamento dos } \\
\text { doentes. } \\
\text { Pode também ser resultado } \\
\text { da resistência das pessoas. } \\
\text { A prevenção foi um fator } \\
\text { importante pra reduzir a }\end{array}$ \\
\hline
\end{tabular}




\begin{tabular}{|c|c|}
\hline & doença. \\
\hline $\begin{array}{l}\text { Os trabalhadores do desmatamento também pegavam } \\
\text { malária. Todos, sem distinção, eram afetados, ricos e } \\
\text { pobres. }\end{array}$ & \\
\hline $\begin{array}{l}\text { Não pegavam a malária algumas pessoas mais } \\
\text { resistentes. } \\
\text { O tratamento da SUCAM era gratuito (quinino, cloroquina, } \\
\text { aralen). }\end{array}$ & \\
\hline $\begin{array}{l}\text { A malária provocou o retorno de famílias para o Paraná. } \\
\text { Os garimpeiros nem sempre recebiam socorro. Em alguns } \\
\text { casos, não havia estradas que ligavam os garimpos para a } \\
\text { cidade. As saídas eram só de avião. Muitos patrões } \\
\text { passavam na SUCAM e levavam os medicamentos para } \\
\text { os locais de garimpo. }\end{array}$ & \\
\hline $\begin{array}{l}\text { Havia só um posto da SUCAM. O diagnóstico era feito em } \\
\text { um dia e o resultado saia no seguinte. Os funcionários da } \\
\text { SUCAM acompanhavam a admissão dos remédios. } \\
\text { 1ํhospital do Dr. Gomes (atual prefeitura) e } 1^{\text {1 }} \text { farmácia } \\
\text { (de sua esposa). Depois "Divina Providência" e "Cristo } \\
\text { Redentor". Depois Hospital Municipal. O atendimento era } \\
\text { bastante caro, cobrado em peso de ouro. }\end{array}$ & \\
\hline $\begin{array}{l}\text { As pessoas se tratavam com as plantas melão-de-são- } \\
\text { caetano e quina, duas plantas amargas. Levavam a planta } \\
\text { para o garimpo. }\end{array}$ & \\
\hline $\begin{array}{l}\text { Pessoas se preveniam com alho e melão-de-são-caetano. } \\
\text { Tomavam também fedegoso com óleo de rince. } \\
\text { "Jogava uma "boroca" nas costas, uma rede e um bocado } \\
\text { de roupa e sumia. Chegava lá, dormia em rede, exposto a } \\
\text { tudo. Com a malária estourou, todo começou a prevenir, } \\
\text { dormia em "fuscão" (barraco), levava mosquiteiro, outros } \\
\text { levavam repelente e levava remédio". }\end{array}$ & \\
\hline $\begin{array}{l}\text { "Muito pai de família morreu porque o ouro era a ganância } \\
\text { do povo". }\end{array}$ & \\
\hline $\begin{array}{l}\text { De cada } 10 \text { pessoas, nove pegavam malária. Todos: } \\
\text { homens, mulheres e crianças. }\end{array}$ & \\
\hline $\begin{array}{l}\text { Quem tinha "fuscão" era o dono da draga, a cozinheira. } \\
\text { Três palanques e uma lona preta. As pessoas dormiam em } \\
\text { redes. }\end{array}$ & \\
\hline $\begin{array}{l}\text { Quando o funcionário adoecia e precisava gastar com o } \\
\text { tratamento, o patrão fazia um adiantamento e depois } \\
\text { descontava em serviço. }\end{array}$ & \\
\hline $\begin{array}{l}\text { Muitos agricultores não foram para o garimpo porque, no } \\
\text { garimpo, a vida era muito difícil. }\end{array}$ & \\
\hline $\begin{array}{l}\text { Os trabalhadores sabiam que a doença era transmitida } \\
\text { pelo mosquito. }\end{array}$ & \\
\hline Teve agricultores que perderam tudo por causa da malária. & \\
\hline $\begin{array}{l}\text { Agricultores que tinham recursos saiam pra se tratar. Os } \\
\text { que não tinham acabam morrendo. }\end{array}$ & \\
\hline $\begin{array}{l}\text { Os paranaenses não sabiam o que era malária. Acham } \\
\text { que era gripe. Acabavam morrendo. }\end{array}$ & \\
\hline
\end{tabular}

\begin{tabular}{|l|l|l|}
\hline Fases do ciclo & Agricultura e garimpo & Madeira e pecuária \\
\hline $\begin{array}{l}\text { Leishmaniose } \\
\text { tegumentar }\end{array}$ & Muitos casos & Muitos casos \\
\hline $\begin{array}{l}\text { Doenças respiratórias } \\
\mathbf{1 9 8 4} / \mathbf{8 5}-\mathbf{2 0 0 5 / 6}\end{array}$ & $\begin{array}{l}\text { Muitas queimadas, muitas pessoas com } \\
\text { doenças respiratórias, principalmente }\end{array}$ & $\begin{array}{l}1993 \text { - Quando desmataram } \\
\text { no entorno da cidade, e }\end{array}$ \\
\hline
\end{tabular}




\begin{tabular}{|c|c|c|}
\hline \multirow[t]{5}{*}{ Pneumonia, asma, etc. } & crianças e idosos. & $\begin{array}{l}\text { queimaram, as pessoas } \\
\text { ajudaram a levar crianças } \\
\text { para o hospital. Os hospitais } \\
\text { ficaram lotados. }\end{array}$ \\
\hline & Falta de ar. & \\
\hline & Fogo de floresta derrubada. & \\
\hline & $\begin{array}{l}\text { Não tinha fiscalização ambiental. } \\
\text { Derrubava, fazia aceiros e metia fogo. } \\
\text { Não se fazia leiras. }\end{array}$ & \\
\hline & $\begin{array}{l}\text { Muitas vezes ficava sem sol por causa } \\
\text { das queimadas. Na época de agosto o } \\
\text { sol desapareceria durante todo o mês. } \\
\text { Ardia o nariz. O ônibus não podia } \\
\text { circular, tinha que esperar diminuir as } \\
\text { queimadas para conseguir passar. } \\
\text { Queimavam os mosquitos. }\end{array}$ & \\
\hline \multirow{8}{*}{$\begin{array}{l}\text { Doenças crônicas } \\
2000 \\
\text { Canceres, ataques } \\
\text { cardíacos, pressão alta, } \\
\text { diabetes, doenças } \\
\text { nervosas e neurológicas } \\
\text { (Alzheimer e Parkinson) }\end{array}$} & $\begin{array}{l}\text { As pessoas vieram com idade entre } 30 \\
\text { e } 55 \text { anos. }\end{array}$ & $\begin{array}{l}\text { No tempo da malária não } \\
\text { tinha ataque cardíaco. }\end{array}$ \\
\hline & $\begin{array}{l}\text { Não existia câncer, problemas de } \\
\text { coração. Mas, também, não tinha } \\
\text { médicos. }\end{array}$ & \\
\hline & $\begin{array}{l}\text { Faltava dinheiro e informação para os } \\
\text { tratamentos médicos. }\end{array}$ & \\
\hline & $\begin{array}{l}\text { Tinha algumas poucas pessoas com } \\
\text { problemas de hipertensão. }\end{array}$ & \\
\hline & $\begin{array}{l}\text { Uso de agrotóxicos para cupim, nas } \\
\text { plantações (ferrugem e cigarrinha). }\end{array}$ & \\
\hline & $\begin{array}{l}\text { Passava veneno de avião nas } \\
\text { pastagens. } \\
\text { AD20, máquinas usadas na } \\
\text { pulverização de arroz para matar } \\
\text { cigarrinhas. }\end{array}$ & \\
\hline & $\begin{array}{l}\text { As pessoas mexiam com veneno sem } \\
\text { proteção (máscara, etc.). Contam que } \\
\text { ficavam com a roupa branquinha. }\end{array}$ & \\
\hline & $\begin{array}{l}\text { O Tordon era usado no pasto. } \\
\text { No Paraná usavam veneno em pó: } \\
\text { BHC e Aldrin. O BHC era usado para } \\
\text { matar mosquito. }\end{array}$ & \\
\hline
\end{tabular}

\begin{tabular}{|c|c|c|}
\hline Fases do ciclo & Fiscalização e pecuária & Hidrelétrica, pecuária e soja \\
\hline $\begin{array}{l}\text { Leishmaniose } \\
\text { tegumentar }\end{array}$ & Muitos casos & $\begin{array}{l}\text { Diminui o número de casos de } \\
\text { leishmaniose. }\end{array}$ \\
\hline Dengue & Comecou a dengue & Muita dengue \\
\hline \multirow[t]{4}{*}{$\begin{array}{l}\text { Doenças respiratórias } \\
1984 / 85-2005 / 6 \\
\text { Pneumonia, asma, etc. }\end{array}$} & $\begin{array}{l}\text { Ainda tinha muita queimada } \\
\text { oriunda do uso do fogo na } \\
\text { limpeza de pastagem, } \\
\text { principalmente nas grandes } \\
\text { fazendas. }\end{array}$ & $\begin{array}{l}\text { Hoje o ar quente desce hoje. } \\
\text { Antigamente não era assim. }\end{array}$ \\
\hline & & $\begin{array}{l}\text { As doenças respiratórias podem } \\
\text { resultar da poluição dos automóveis. } \\
\text { Eles acham que essa forma de } \\
\text { poluição é mais tóxica. }\end{array}$ \\
\hline & & $\begin{array}{l}\text { As chuvas hoje são bem mais fortes } \\
\text { do que antigamente. }\end{array}$ \\
\hline & & Hoje chove bem menos que no \\
\hline
\end{tabular}




\begin{tabular}{|l|l|l|}
\hline & & $\begin{array}{l}\text { início. Os poços de água } \\
\text { derramavam no início. Agora, } \\
\text { mesmo na época da chuva a agua } \\
\text { do poço não sobe mais. Muitos } \\
\text { poços que derramavam, agora } \\
\text { secaram. }\end{array}$ \\
\hline $\begin{array}{l}\text { Doenças crônicas } \\
\mathbf{2} 2000\end{array}$ & $\begin{array}{l}\text { Ataques cardíacos e derrames } \\
\text { podem estar relacionados à } \\
\text { cardíacos, ataques } \\
\text { poluição atmosférica produzida alta, } \\
\text { diabetes, doenças } \\
\text { nervosas e neurológicas } \\
\text { (Alzheimer e Parkinson) }\end{array}$ & $\begin{array}{l}\text { Soja: está acabando com o meio } \\
\text { ambiente e a saúde. } \\
\text { Suspeita de soja ajudar na } \\
\text { descalcificação. }\end{array}$ \\
\cline { 2 - 3 } & $\begin{array}{l}\text { A água está contaminada de } \\
\text { lixo e esgoto. }\end{array}$ & $\begin{array}{l}\text { O esterco de gado não é mais usado } \\
\text { em hortas por causa do veneno. }\end{array}$ \\
\cline { 2 - 3 } & $\begin{array}{l}\text { As doenças crônicas } \\
\text { aumentaram muito, } \\
\text { principalmente as do coração: } \\
\text { causadas pelo calor e má } \\
\text { alimentação (gordura - banha } \\
\text { de porco, margarina). } \\
\text { Câncer: comidas } \\
\text { industrializadas, óleo de soja. } \\
\text { Há uso de agrotóxicos na } \\
\text { pastagem para matar cupim, } \\
\text { assapeixe e uso de vacinação e } \\
\text { hormônios. }\end{array}$ & \\
\hline
\end{tabular}

